\title{
ANÁLISE E PROPOSTA DE FORMAS DE GERENCIAMENTO DE ESTAÇÕES DE TRATAMENTO DE ÁGUAS DE ABASTECIMENTO COMPLETO EM CIDADES DE PORTE MÉDIO DO ESTADO DE SÃO PAULO
}

\author{
MARILU PEREIRA SERAFIM PARSEKIAN \\ Dissertação apresentada à Escola de Engenharia de São \\ Carlos, da Universidade de São Paulo, como parte dos \\ requisitos para obtenção do Título de Mestre em \\ Hidráulica e Saneamento.
}

ORIENTADOR: Prof. Dr. João Sérgio Cordeiro

São Carlos

1998 


\section{SUMÁRIO}

LISTA DE FIGURAS __iii

LISTA DE TABELAS _ iv

LISTA DE FOTOGRAFIAS _ $v$

LISTA DE SÍMBOLOS _

RESUMO

ABSTRACT —vii

1. INTRODUÇÃO 1

2. OBJETIVO

3. REVISÃO BIBLIOGRÁFICA__ 6

3.1. Aspectos Gerais ______ 6

3.2. Sistema de Tratamento de Água para Abastecimento _______________ 12

3.2.1. Caracterização dos Mananciais e dos Sistemas de Tratamento de Água Completo _____- 12

3.3. Serviço de Abastecimento de Água __-__-__-__-_-_

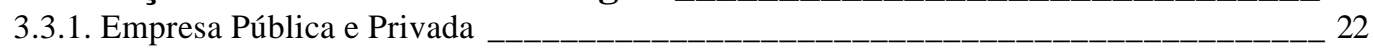

3.4. A Pesquisa Tecnológica e Científica em ETA Convencionais e a

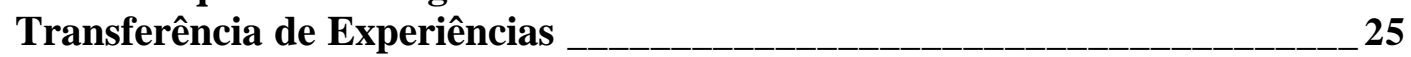

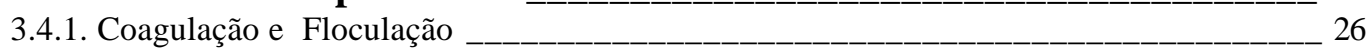

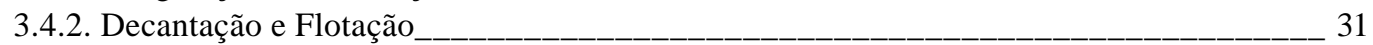

3.4.3. Filtração ___ 43

3.4.4. Resíduos Gerados e Âgua de Lavagem -_-_-_-_-_ 51

3.5. A Evolução do Pensamento Gerencial ___ 56

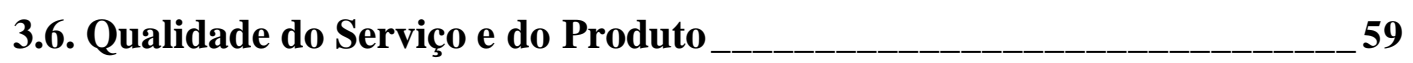

3.7. Gerenciamento da Produção _-_____ 66

3.8. Gerenciamento da Qualidade ______ 69

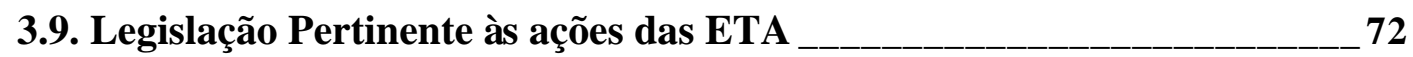

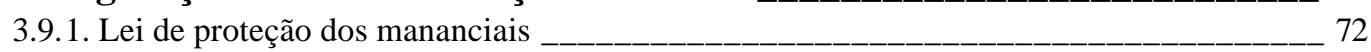

3.9.2. Lei das concessões

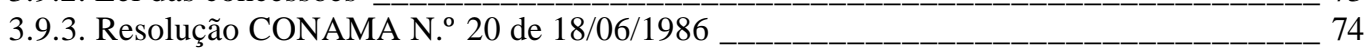

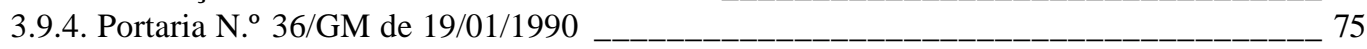

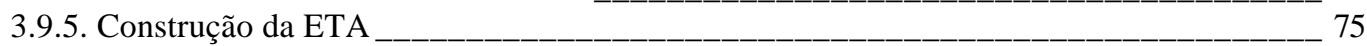

3.9.6. Produtos químicos__-_-_-_-_-_-_-_-_-_-_-_-_-_-_-_-_-_-_-_-_-_-_-_-_-_-_-_-_-_- 75

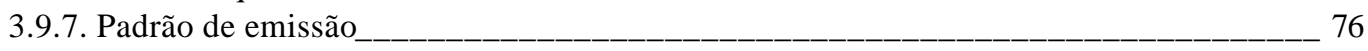

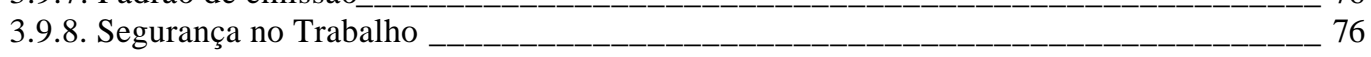

4. MÉTODOS E MATERIAIS___ 80

5. RESULTADOS E DISCUSSÕES___ 86

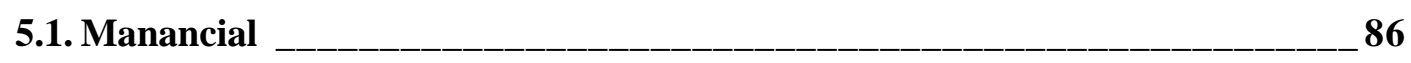


5.2. Condições operacionais 97

5.2.1. Produtos químicos 98

5.2.2. Análise das etapas envolvidas no processo 100

5.2.3. Limpeza do sistema de tratamento 104

5.3. Grau de instrução dos recursos humanos 117

5.4. Consumo de produtos químicos e energia elétrica 121

5.5. Segurança no trabalho 129

5.6. Administração do Serviço de Água 131

5.7. Modelo gerencial para estação de tratamento de água de abastecimento 138

6. CONCLUSÕES 141

7. PROPOSTAS 144

ANEXO A 148

ANEXO B 152

ANEXO C 157

REFER $\hat{E} N C I A S$ BIBLIOGRÁFICAS 178 


\section{LISTA DE FIGURAS}

Figura 1: Esquema dos aspectos relacionados à estação de tratamento de água_________________ 7

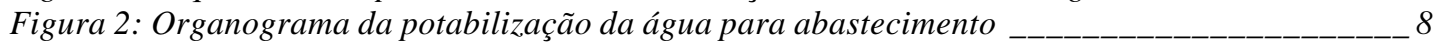

Figura 3: Organograma do processo de tratamento de água completo___________________________ 8

Figura 4: Gráficos simulando como a qualidade do manancial interfere no serviço de tratamento de

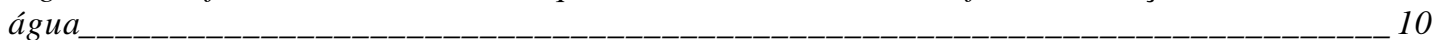

Figura 5: Classificação das tecnologias de tratamento de água para consumo humano _-_-_ 14

Figura 6: Visão sistêmica necessária para o serviço de água para abastecimento _____________ 58

Figura 7: Esquema do processo de potabilização da água

Figura 8: Modelo geral de administração da produção e estratégia de produção_________-___-__ 66

Figura 9: Modelo de Gerenciamento de projeto_____________________________________________ 69

Figura 10: Características da água bruta que abastece a ETA $G$

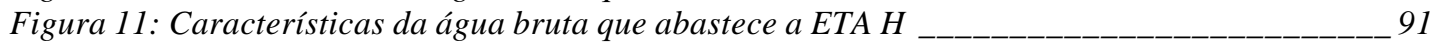

Figura 12: Porcentagem de estações de tratamento de água que possuem programa de proteção dos mananciais nas cidades visitadas

Figura 13 : Controle de Qualidade dos Produtos Químicos_________________________________ 99

Figura 14: Controle da quantidade de água utilizada em lavagens e descargas_____________ 105

Figura 15: Nível de escolaridade dos operadores das ETA estudadas em relação ao número total

destes funcionários

Figura 16: Consumo de coagulante por volume de água tratada $\left(\mathrm{kg} / \mathrm{m}^{3}\right)$

Figura 17: Características da água bruta das ETA H e J no ano de 1996

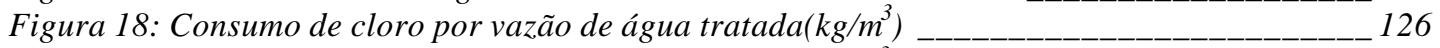

Figura 19: Consumo de cal por volume de água tratada $\left(\mathrm{kg} / \mathrm{m}^{3}\right)$

Figura 20: Consumo de energia elétrica por volume de água tratada $\left(\mathrm{kwh} / \mathrm{m}^{3}\right)$ ______________ 128

Figura 21: Organograma do Serviço de Abastecimento de Água da cidade L________________ 131

Figura 22: Organograma Administrativo do Serviço de Água referente às $\quad$ ETA G e H____ 134

Figura 23: Organograma administrativo da ETA E__________________________________________ 136

Figura 24: Organograma do Serviço de Abastecimento de Á gua das ETA I e J. ______________ 137

Figura 25: Modelo geral de administração para estação de tratamento de água______________ 139 


\section{LISTA DE TABELAS}

Tabela 1: Classificação das Bacias dos rios Atibaia, Piracicaba e Mogi-Guaçu, com o número de cidades pertencentes à Bacia, quantas tratam o esgoto e quantas captam água para abastecimento e quantidade de lançamento de poluentes.....................................................................................................13

Tabela 2: Produtos químicos empregados no tratamento de água e suas referidas normas.................. 76

Tabela 3: Características das ETA: tipo de coagulante, número de decantadores e filtros....................82

Tabela 4: Caracterização das ETA visitadas..............................................................................................8

Tabela 5: Caracterização da Água Bruta das ETA visitadas.....................................................................84

Tabela 6: Aspectos observados nas cidades visitadas.............................................................................85

Tabela 7: Condições atuais, Controle de qualidade e proteção dos mananciais.......................................87

Tabela 8: Situação dos corpos d'agua da Bacia do Rio Piracicaba em 1990..........................................88

Tabela 9:Análises realizadas diariamente pelas estações de tratamento de água na água bruta.........92

Tabela 10: Vazão de projeto e vazão de operação das estações de tratamento de água visitadas.......97

Tabela 11 : Aquisição, Controle de qualidade e Dosagem de Produtos Químicos.................................98

Tabela 12: Especificação feita pelas ETA para aquisição do produto químico. Comparação com o

modelo sugerido em Saneamento e Municípios (Dez 96/Jan 97).......................................................... 101

Tabela 13: Observação de operação, Controle da qualidade da água, Dados físico-químicose

bacteriológicos....................................................................................................................................... 101

Tabela 14: Relação dos equipamentos existentes nos laboratórios das estações de tratamento de água visitadas.... 103

Tabela 15: Controle de quantidade da utilizada na lavagem de filtros e dencantadores e descargas nos tanques de decantação.

Tabela 16: Volume de água aduzida, volume de água utilizada na lavagem de filtros, volume de água descartado, volume de água distribuída e porcentagem de perda de água na ETA G........................ 105 Tabela 17: Volume de água aduzida, volume de água utilizada na lavagem de filtros, volume de água descartado, volume de água distribuída e porcentagem de perda de água na ETA H......................... 106 Tabela 18: Freqüência de limpeza dos decantadores e destino dos rejeitos dos decantadores e filtros

Tabela 19: Grau de instrução dos operadores de estação de tratamento de água.............................. 118

Tabela 20: Grau de escolaridade dos responsáveis pelas Estações de tratamento de água............... 119

Tabela 21: Grau de escolaridade dos responsáveis pelos laboratórios das ETA visitadas. ................ 120

Tabela 22: Volume de água tratada, Consumo de energia elétrica, Consumo de produtos químicos no ano de 1996........................................................................................................................................... 122

Tabela 23: Relação consumo de energia elétrica/volume de água tratada e consumo de produtos químicos/volume de água tratada................................................................................................................. 123

Tabela 24: Relação de equipamentos de segurança existentes nas ETA visitadas................................ 130

Tabela 25: Fornecedores de produtos químicos das estações de tratamento de água visitadas referentes ao ano de 1996............................................................................................................................ 153

Tabela 26: Características da água bruta da ETA H referente ao ano de 1996. Valores médios mensais.......................................................................................................................................... 155

Tabela 27: Características da água bruta da ETA J referente ao ano de 1996. Valores médios mensais.. 


\section{LISTA DE FOTOGRAFIAS}

Fotografia 1: Limpeza do canal de captação da ETA C ............................................................................94

Fotografia 2: Manutenção da captação da ETA D ................................................................................94

Fotografia 3:Rodovia passando em cima do rio de onde é captada água para a ETA E.......................95

Fotografia 4: Manancial que abastece a ETA A com floração de algas..................................................95

Fotografia 5: Armazenamento de cal da ETA B próximo à poças d'água............................................. 100

Fotografia 6: Desinfecção e correção de pH da ETA C ..................................................................... 100

Fotografia 7: Vazamento nas bombas da ETA A ...................................................................................... 108

Fotografia 8: Vazamento na galeria dos filtros da ETA A ..................................................................... 108

Fotografia 9: Vazamento no filtro da ETA D ......................................................................................... 109

Fotografia 10: Vazamento na galeria de filtros da ETA I ..................................................................... 109

Fotografia 11: Vazamento na galeria de filtros da ETA J ..................................................................... 110

Fotografia 12: Vazamento na galeria de filtros da ETA $L$..................................................................... 110

Fotografia 13: Infiltração na parede do filtro da ETA C ..................................................................... 111

Fotografia 14: Infiltração na parede filtro na ETA ................................................................................ 111

Fotografia 15: Perda de material filtrante na ETA D ............................................................................ 112

Fotografia 16: Decantador da ETA F - Ocorrência de flotação .......................................................... 113

Fotografia 17: Lavagem do decantador da ETA I.............................................................................. 113

Fotografia 18: Piezômetros dos filtros das ETA G e H ......................................................................... 114

Fotografia 19: Controle do nível do canal de entrada aos filtros da ETA G........................................ 114

Fotografia 20: Floculador sobrecarregado da ETA J ......................................................................... 115

Fotografia 21: Lavagem filtro da ETA E .......................................................................................... 115

Fotografia 22: Trinca canal de água floculada da ETA I................................................................. 116

Fotografia 23: Trinca reservatório da ETA. .............................................................................................. 116

\section{LISTA DE SÍMBOLOS}

DQO - Demanda química de oxigênio $\left(\mathrm{mg} / \mathrm{L} \mathrm{O}_{2}\right)$

$\mathrm{CD}$ - Coeficiente de desuniformidade

$\mathrm{K}$ - Coeficiente do rotor

$\mathrm{G}$ - Gradiente de velocidade média $\left(\mathrm{s}^{-1}\right)$

ETA - Estação de tratamento de água

GQT - Gerenciamento da qualidade total

SFTD - Sistema de filtração com taxa declinante

$\mathrm{N}_{1}$ - Nível no canal comum de alimentação dos filtros em que a vazão total efluente se igual à do afluente

$\mathrm{N}_{2}$ - Nível no canal comum de alimentação dos filtros correspondente ao instante em que o filtro mais sujo da bateria é retirado de operação para lavagem

$\mathrm{F}_{1}-$ Filtro 1

$\mathrm{F}_{2}-$ Filtro 2

$\mathrm{F}_{3}-$ Filtro 3

$\mathrm{F}_{4}-$ Filtro 4 


\section{RESUMO}

As estações de tratamento de água são indústrias nas quais a água bruta (matéria prima) deve ser transformada em água potável (produto final) através da aplicação de produtos em operações e processos. Esta indústria é uma das poucas à qual todos os seres humanos fazem uso do seu produto.

Nos últimos tempos tem-se constatado aumento da demanda que, aliado a sensível piora da qualidade da água bruta, conduz à necessidade de funcionamento eficiente das estações, tanto do ponto de vista técnico, quanto do econômico. Essa eficiência só será atingida através de gerenciamento adequado.

Com vistas às necessidades de nosso país nesse setor, levantou-se informações sobre algumas estações de tratamento de água de abastecimento através de visitas e aplicação de questionário elaborado. Analisou-se formas de gerenciamento para estas estações de modo que o resultado possibilitasse melhoria do produto e do serviço. Cabe salientar que este trabalho não apresenta uma análise quantitativa dos custos.

O desenvolvimento do trabalho permitiu algumas conclusões: de maneira geral não tem existido por parte dos sistemas gerenciadores grandes preocupações com a qualidade dos mananciais; a aquisição dos produtos químicos é realizada pelo menor preço; um número pequeno das ETA visitadas adotam critério técnico para fazer as dosagens de produtos químicos; os resíduos gerados nos decantadores e filtros são descartados nos cursos d'água próximos às ETA; entre outras.

A partir destas conclusões pôde-se propor medidas para o melhor funcionamento destas estações.

Palavras-chave: gerenciamento; estação de tratamento de água; qualidade do produto. 


\section{ABSTRACT}

Water treatment plants are industries in which untreated water (raw material) has to be changed into drinking water (the final product) through the use of products in operations and processes. This is one of the few industries that the product of which all human beings make use of.

In recent years an increase in the demand of water has been observed which, closely linked to a decline in the untreated water quality, results in the necessity for a more efficient operation of the water treatment plants from the technical point of view as well as the economical one. This efficiency will only be reached through adequate management.

Looking at our country's necessities in this area, information was gathered about some water treatment plants through visits and a purpose made questionnaire. For these plants the different forms of management were analyzed so that the result would improve the product and the service. We must point out that this study does not present any quantitative analysis of costs.

The development of this study allowed us to reach some conclusions: in general there were no great worries by the managerial systems about the quality of the water sources; the acquisition of the chemical products is made by paying the minimum price; a small number of plants that were visited adopted a technical criterion to feed in chemical products; the residue produced in the treatment tanks of sedimentation and filters is disposed in the waterways near the plants; among others.

Based on these conclusions some better norms for the functioning of these plants can be proposed.

Key words: management, water treatment plants; quality of the product 


\section{INTRODUÇÃO}

A água deve chegar ao consumidor, atendendo ao padrão de potabilidade estabelecido. Além disso, os custos inerentes ao processo de tratamento de água devem ser os menores possíveis, evitando que a população venha a arcar com grandes prejuízos financeiros. Assim, é necessário que os envolvidos no tratamento de água estejam cientes do sistema como um todo para que a relação custo/benefício seja a menor possível.

Os sistemas de abastecimento de água têm sido analisados de maneira restrita, o que impede que se analise o problema do tratamento de água de forma integrada. Desta forma, muitos problemas decorrentes das operações e processos não são equacionados corretamente.

Quando se busca a qualidade nos serviços prestados à população, se torna extremamente importante a visão abrangente de todos os subsistemas componentes do tratamento de água.

A concepção industrial dos sistemas de tratamento deve ser cada vez mais enfocada. Nessa indústria a matéria prima (água bruta) recebe produtos químicos (por exemplo sulfato de alumínio ou cloreto férrico, cal, auxiliares de floculação, cloro, etc.) e através de operações e processos se transforma em água para consumo humano. Vale salientar que a indústria da água é uma das poucas à qual todos os seres humanos fazem uso do seu produto, sendo esta essencial para a sobrevivência e desenvolvimento dos seres humanos.

A pesquisa desenvolvida enfoca a visão industrial na estação de tratamento de água de abastecimento levantando algumas questões para que as mesmas possam aplicar gerenciamento eficiente. O objetivo de desenvolver tal trabalho partiu de perguntas para as quais não eram encontradas respostas com embasamento científico. Algumas das perguntas foram: $\mathrm{O}$ tratamento de água completo têm sido adequado? Existe uma garantia de manutenção da qualidade de água dos mananciais? Qual a 
qualidade do produto químico empregado? Como é feita a dosagem de produtos químicos? Esta estação de tratamento de água gera algum tipo de resíduo? Qual a qualidade da água tratada? Os operadores estão trabalhando com segurança? É feito algum controle da qualidade da água que está chegando às residências? Essas e várias outras perguntas foram levantadas a fim de apontar se o desenvolvimento de um programa de gerenciamento em estações de tratamento de água completo era viável e qual a sua importância para a população abastecida.

A visão sistêmica é um suporte teórico, porém o seu sucesso só é obtido quando paralelamente a ela desenvolve-se um objetivo comum, o qual deverá ser trabalhado em conjunto. As pessoas envolvidas nas atividades da empresa deverão passar por treinamentos a fim de conseguir obter domínio pessoal e eliminar modelos mentais (preconceitos). Essas ações juntamente com a visão sistêmica, podem ajudar a descobrir problemas e quais os possíveis meios de superá-los.

De acordo com pesquisa realizada por Alan Carter (1995), equipes que empregam programa de gerenciamento apresentam vários benefícios, tais como: obtenção de um produto que atende melhor o uso, desenvolvimento da organização da equipe, sendo que o extenso processo de planejamento produz uma sólida documentação e economia de tempo e custo no desempenho de tarefas futuras.

De acordo com DIAS (1995), a implantação da ISO 14000 (1996), que certifica não somente a qualidade dos produtos, como também garante os procedimentos necessários para manter a integridade dos processos que levam a essa qualidade, de modo que a qualidade dos produtos e seus respectivos processos não provoquem danos ambientais, mostra uma visão mundial sobre a necessidade de desenvolver programas gerenciais onde o processo e o produto devem atender e satisfazer as necessidades do homem, sem agredir o meio ambiente. Foram traduzidas para o português as normas ISO 14001 e 14004, sobre os sistemas de gestão ambiental, e as normas ISO 14010, 14011 e 14012, sobre auditoria ambiental. Não deve-se esquecer que hoje grande parte dos serviços de água ainda não estão enquadrados na ISO 9.000 (que certifica a qualidade dos produtos, garantindo os procedimentos necessários para manter a integridade dos processos que levam a essa qualidade). 
Existem no Brasil aproximadamente 7.500 estações de tratamento de água de abastecimento completas, onde a grande maioria não apresenta programas de preservação e recuperação de mananciais, de controle de perdas, de treinamento eficientes e contínuos dos operadores, entre outros, caracterizando assim a ausência de gestão eficiente nestas empresas.

Recentemente, a Secretaria de Obras e Recursos Hídricos de São Paulo divulgou no Informativo do Instituto de Engenharia (março/97) a preocupação com a demanda e a qualidade da água para abastecimento, pois o Estado de São Paulo só possui 1,6\% dos recursos de água doce brasileira; dos quais já se utilizou, até 1990, 16\% e a projeção para 2010 é que chegue a utilizar 25\% desse recurso. A demanda projetada será superior a toda a disponibilidade hídrica superficial e subterrânea das oito bacias hidrográficas do Estado. Somando a esse aumento de demanda encontrase o problema de poluição dos mananciais devido aos usos múltiplos dos corpos d'água sem o tratamento das águas residuárias, de modo a degradar a qualidade da água bruta, a qual poderá influenciar na qualidade da água que será destinada à população após o seu tratamento.

Segundo MICHIGAN (1998), "a proposta de lei do governo estadual, desenvolvida pelas Secretarias do Meio Ambiente e de Recursos Hídricos, Saneamento e Obras de São Paulo sobre a cobrança pelo uso da água, é justamente a de impedir que a situação chegue ao colapso. Baseada no modelo de gestão da França, país no qual a cobrança é feita há 30 anos, a lei prevê a participação ativa da sociedade por intermédio de 20 Comitês de Bacias Hídricas. Cada comitê tem representantes de órgãos do governo estadual, municipal e da sociedade civil. Os 20 comitês estão encarregados de detectar os problemas de suas bacias e criar um Plano de Bacia para determinar os projetos de preservação e recuperação dos mananciais e também o custo de tudo isso.

A partir desse custo, o Conselho de Recursos Hídricos (CRH) deverá fixar a taxa da cobrança, estabelecendo um preço mínimo e um máximo. Caberá aos comitês determinar quem paga e quanto paga. Os comitês terão autonomia para isentar ou taxar um determinado setor. Podem ainda cobrar só a captação, o consumo ou a quantidade de poluentes descarregados na água. O preço poderá variar também conforme o tipo de manancial e a época do ano. 
A necessidade de melhorar o sistema de abastecimento é incontestável, várias empresas e entidades ligadas ao setor de saneamento estão discutindo o tema, como no evento realizado pela ABES, a 52 $2^{\mathrm{a}}$ Reunião do Comitê de Recursos Humanos em Vitória no mês de novembro de 1996, na qual foram abordados temas como modelos de gestão. Entre outras participantes deste encontro estava a COPASA (companhia do Estado de Minas Gerais, que vem desenvolvendo trabalhos interessantes sobre gerência), mostrando que já existe uma preocupação nacional quanto à melhor administração das empresas de saneamento.

Procurando identificar respostas para as questões levantadas, foi feito um vasto estudo de algumas estações de tratamento completo de água de abastecimento. A metodologia utilizada, os dados e problemas levantados, assim como as conclusões resultantes desse estudo, encontram-se descritos a seguir.

No capítulo 3 é feita uma vasta revisão bibliográfica abordando os sistemas de tratamento de água para abastecimento, os serviços de abastecimento de água, pesquisas tecnológicas e científicas desenvolvidas pela Escola de Engenharia de São Carlos/Universidade de São Paulo sobre tratamento completo de água para abastecimento, evolução do pensamento gerencial neste setor, qualidade do produto e do serviço, gerenciamento da produção e da qualidade e legislação pertinente às ações as estações de tratamento de água.

No capítulo 4 encontra-se descrito a metodologia empregada para o desenvolvimento deste trabalho.

Os resultados são mostrados no capítulo 5, no qual são feitas discussões sobre os mananciais das estações de tratamento de água visitadas, condições operacionais (produtos químicos, etapas envolvidas no processo, limpeza do sistema de tratamento), grau de instrução dos recursos humanos, consumo de produtos químicos e de energia, segurança no trabalho, organogramas administrativos e modelo gerencial para ETA.

As conclusões obtidas através dos dados levantados são apresentadas no capítulo 6.

No capítulo 7 são propostas algumas ações para melhorar a eficiência do gerenciamento nas estações de tratamento de água. 


\section{OBJETIVO}

O objetivo do trabalho é analisar o funcionamento atual da indústria de abastecimento de água em cidades de porte médio na região central do Estado de São Paulo, e através de diagnóstico das ETA propor ações para melhorar o desempenho destas. 


\section{REVISÃO BIBLIOGRÁFICA}

\subsection{Aspectos Gerais}

As pesquisas desenvolvidas em estações de tratamento de água normalmente abrangem uma das diversas áreas que envolvem este sistema.

Estas áreas referem-se à parte técnica do tratamento, aos setores administrativo, econômico e financeiro do serviço, às condições sociais e à saúde da população, à segurança dos operadores e às normas e leis que estabelecem os critérios de funcionamento de todo o sistema.

Esses estudos são extremamente importantes, contudo, para o desenvolvimento deste trabalho buscou-se algo que permitisse perceber o quanto todos estes fatores estão interrelacionados no processo de tratamento.

Uma visão holística dos setores que estabelecem o tratamento de água possibilita visualizar que, para a ETA funcionar adequadamente, esses devem ser analisados conjuntamente.

Uma ilustração esquemática dos diferentes aspectos que estão relacionados a ETA é mostrada pela Figura 1.

De forma sistêmica, grande parte da água bruta utilizada para abastecimento público é captada de mananciais superficiais e bombeada através de adutoras até a estação de tratamento de água (indústria da água) onde são adicionados produtos químicos para efetuar o tratamento da mesma. 


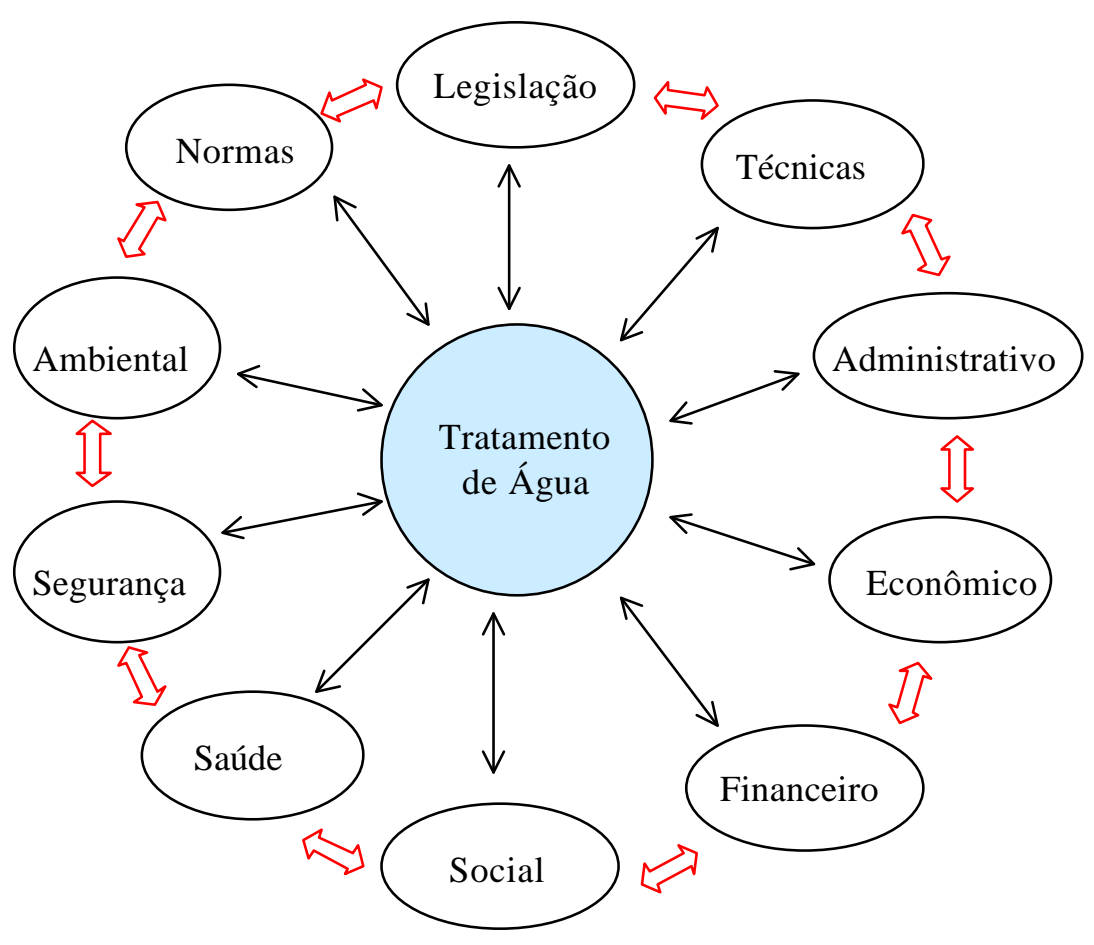

Figura 1: Esquema dos aspectos relacionados à estação de tratamento de água

A Figura 2 mostra que a água para abastecimento pode ser proveniente de dois tipos de mananciais: o manancial subterrâneo (1) e o superficial (2). Normalmente o manancial subterrâneo, quando oferece condições para o abastecimento, necessita de operações mais simples para atingir as condições de potabilidade. Em algumas circunstâncias este pode ser inviável. Quando a captação de água é proveniente de manancial superficial, a desinfecção da água tratada é realizada dentro da estação de tratamento de água, na Figura 2 essa etapa está dissociada da ETA para mostrar que para este tipo de manancial é necessário operações e processos os quais são dispensados para o manancial subterrâneo. 


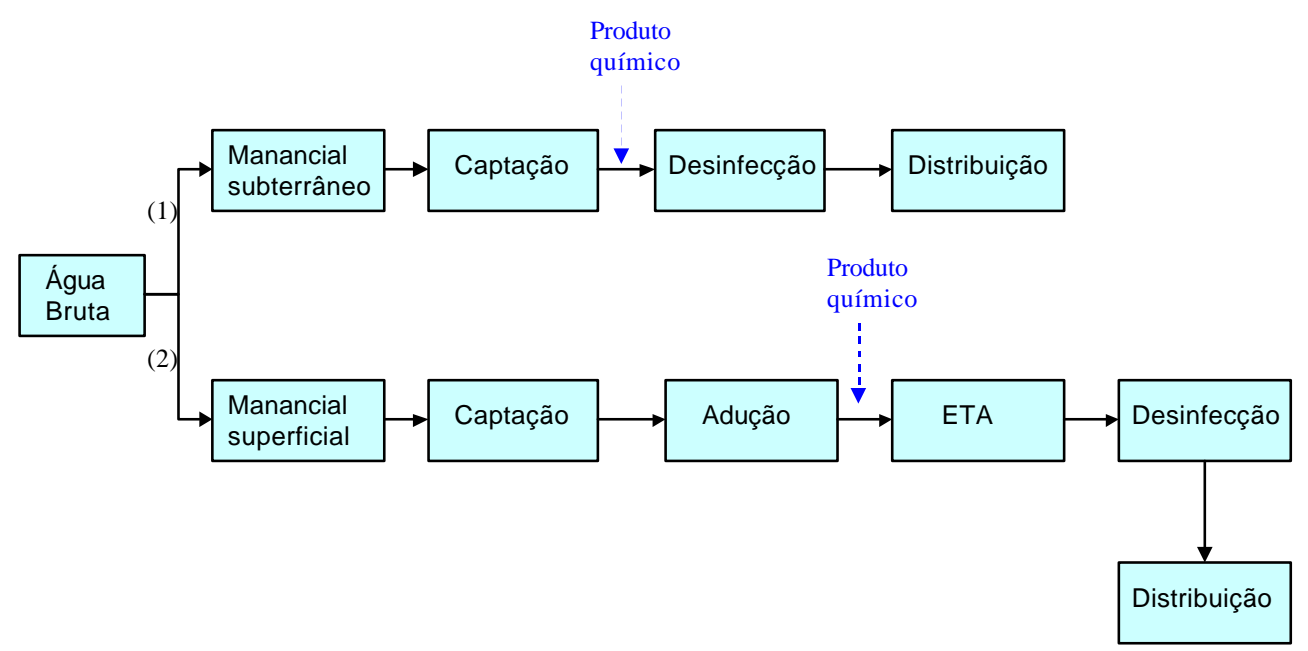

Figura 2: Organograma da potabilização da água para abastecimento

Conforme ilustrado na Figura 3, o processo de tratamento de água completo é constituído pelas etapas de coagulação, floculação, decantação, filtração e desinfecção, a fim de eliminar as impurezas nela presentes, para distribuição aos cidadãos. Neste tratamento há formação de rejeitos, devido à presença de impurezas na água bruta e à aplicação de produtos químicos. Estes rejeitos gerados nos decantadores e nos filtros, na maioria das vezes, são dispostos inadequadamente nos corpos d'água.

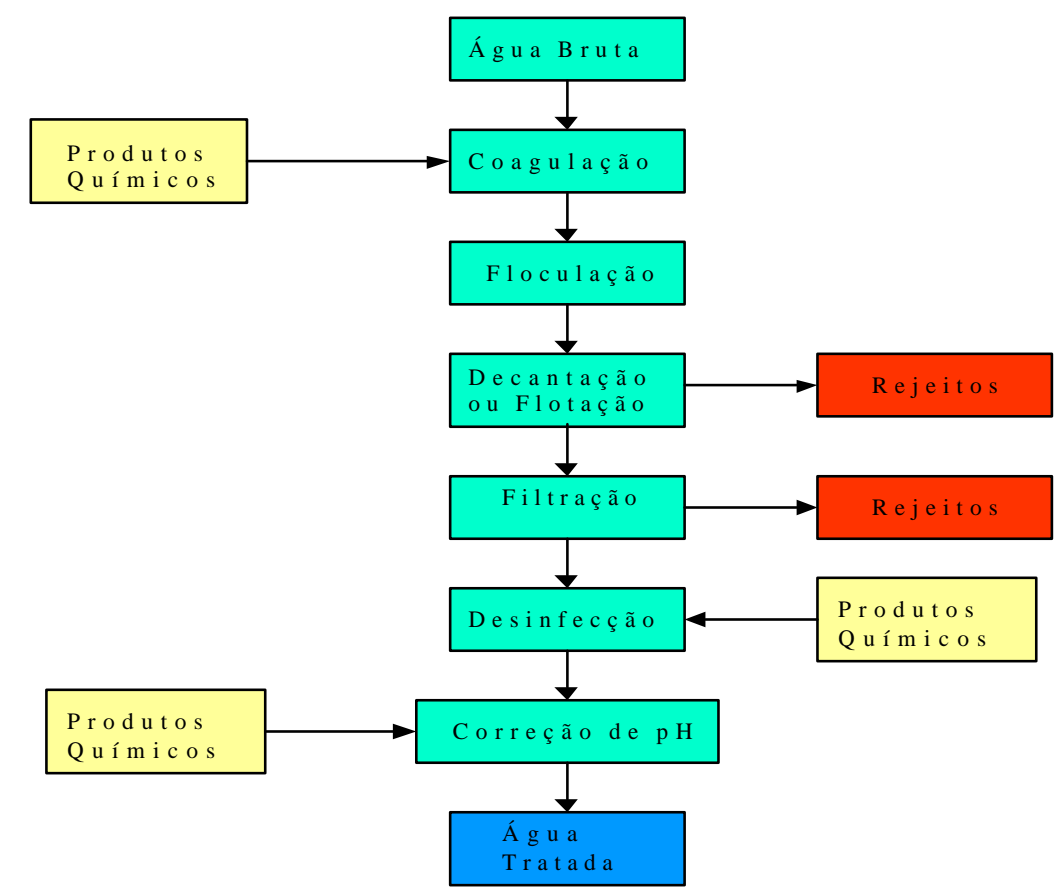

Figura 3: Organograma do processo de tratamento de água completo 
Segundo ROMANO (1996), a água hoje possui o mesmo valor econômico que o petróleo no passado. A persistência em não preservar os recursos hídricos prejudicará nossa qualidade de vida.

"Percebe-se que estamos fazendo pouco ou quase nada para preservar nossa água, somos os responsáveis por sua degradação e temos capacidade de recuperá-la. A água muitas vezes é desperdiçada através de inúmeras formas, desde a falta de manutenção de uma torneira até o desmatamento descontrolado, que ameaça as nascentes e impede a recarga dos mananciais (ROMANO 1996)".

Existem alternativas para se chegar ao uso racional da água, melhor forma de evitar seu desperdício. A mais eficaz, segundo o mesmo autor, é o sistema de gestão dos recursos hídricos, que precisa ser adotado com a participação de toda a comunidade.

Levantamento feito na cidade de Franca, mostra que 3600 hectares de área de preservação ambiental permanente estão com ausência de mata nativa, sendo que nesta área está o manancial responsável pelo abastecimento da cidade. A ausência das matas compromete a qualidade da água na cidade, causando um aumento em $5.000 \%$ na quantidade de sólidos e sedimentos no leito dos córregos no período de chuva. No período de seca, a média de turbidez da água é de 40 uT e com as chuvas essa média passa a 2.000 uT (esse aumento ocorre para as primeiras chuvas e posteriormente reduz-se a $600 \mathrm{uT}$ ). Com a água apresentando estas caraterísticas foi necessário aumento de $30 \%$ no uso de produtos químicos para a remoção das impur,ezas presentes na água que irá abastecer a comunidade. Outro transtorno no tratamento é com a limpeza dos decantadores, os quais antes eram limpos uma vez a cada seis meses e, atualmente, essa limpeza tem sido feita uma vez por mês. Esta reportagem do jornal Folha de São Paulo do dia 22/04/96 mostra o quanto a falta de proteção dos mananciais pode exigir alterações nos processos de tratamento de água.

Como pode ser observado nos gráficos da Figura 4, a qualidade da água bruta é inversamente proporcional à quantidade de produto químico empregado, ou seja, se o manancial sofrer danos e isso prejudicar sua qualidade será necessário aumento da concentração do produto químico de modo a atender as exigências do Padrão de Potabilidade estabelecido pelo Ministério da Saúde através da Portaria 36/GM (1990), sendo que o contrário também é verdadeiro, porém a segunda situação 
atualmente tem sido pouco encontrada. A linha 1 dos gráficos mostra que quando a qualidade do manancial sofre poucas alterações, o mesmo ocorre com a quantidade de produto químico. Pode-se observar que a linha 2 do gráfico 1 indica um decaimento na qualidade do manancial, tendo por isso um aumento da quantidade de produto químico empregado no tratamento da água, conforme mostra a linha 2 do gráfico 2. A situação 3 do gráfico 1, representa elevado nível de poluição do manancial e crescente dosagem de produto químico (gráfico 2), podendo neste caso produzir água com qualidade insatisfatória.
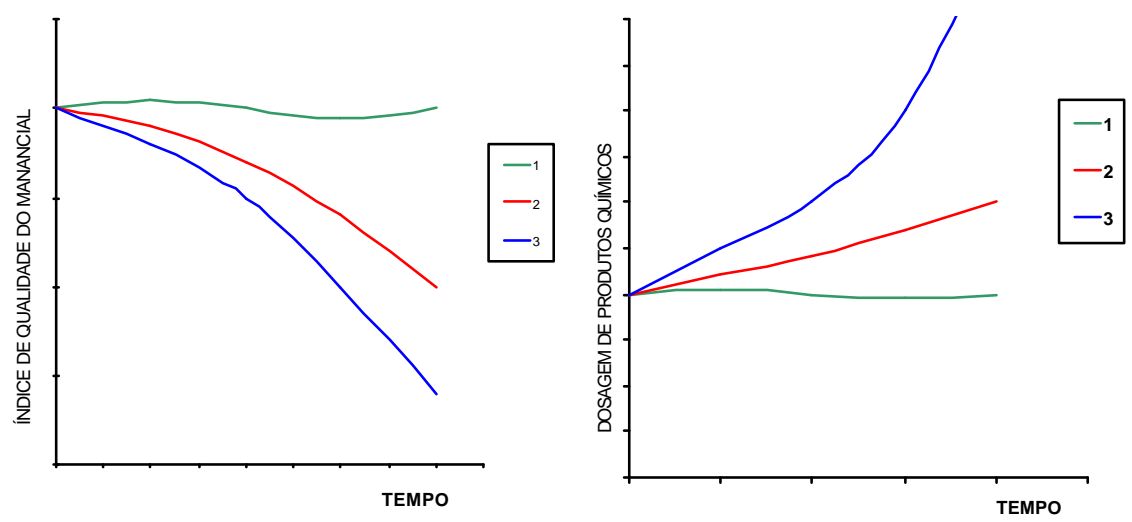

\section{Figura 4: Gráficos simulando como a qualidade do manancial interfere no serviço de tratamento de água}

Estudos realizados por COSTA (1997) em estações de tratamento constataram que a maioria das ETA encontram-se trabalhando acima de sua capacidade nominal e mesmo assim não conseguem atender ao crescente aumento da demanda. Percebeu-se também a ausência de critérios para escolha do coagulante a ser empregado no tratamento. Diante deste diagnóstico, essa mesma pesquisadora realizou trabalho em uma estação com vazão nominal de 120 1/s porém, funcionando com 158 1/s (tal fato ocasionava altos valores de turbidez e cor na água decantada, provocando sobrecarga nos filtros). A água produzida nesta estação de tratamento apresentava valores indesejáveis de turbidez e cor na água tratada. A pesquisadora 
executou vários ensaios com diversos tipos de coagulantes e diferentes dosagens em laboratórios utilizando aparelhos de floculação com reator estático (“jar test”), a fim de determinar o tipo de coagulante mais adequado, o $\mathrm{pH}$ de coagulação e a dosagem ótima do coagulante e auxiliares de floculação adequados. Deste estudo pode-se concluir que a seleção adequada dos produtos, bem como a dosagem ótima pode proporcionar não só a melhoria da qualidade da água, como também o aumento de vazão da mesma, sem que sejam necessárias paralisações prolongadas ou reformas onerosas.

Ao se projetar uma estação de tratamento de água deve-se levar em conta fatores como as características do manancial, a legislação de preservação do recurso hídrico, questões tecnológicas, condições sócioeconômicas da comunidade, capacidade da estação de tratamento, disponibilidade de recursos próprios ou capacidade de endividamento através de financiamento, existência de pessoal qualificado para construção, operação e manutenção, disponibilidade de materiais de construção e de produtos químicos locais ou em regiões próximas, padrão de potabilidade. A escolha de determinada tecnologia de tratamento deve, finalmente, conduzir ao menor custo sem contudo, deixar de lado a segurança na produção de água potável. Sabe-se também que se não houver preservação da qualidade do manancial com o decorrer do tempo, a ETA não estará funcionando conforme projetada, podendo produzir água com qualidade insatisfatória.

Os produtos químicos são empregados no tratamento da água para facilitar a remoção das impurezas nela contida, sendo que a dosagem dos mesmos será determinada em laboratório de acordo com a qualidade da água afluente à ETA. À medida que a qualidade da água bruta sofre variação, o mesmo ocorrerá com a dosagem de coagulantes. Uma questão importante na utilização destes produtos é sua qualidade, pois se estes não atendem as especificações exigidas pelo serviço de água a quantidade destes produtos químicos que será consumida no processo será superior ao usual, o que irá gerar maior quantidade de resíduos nos decantadores e nos filtros e a possibilidade de introdução outras substâncias na água tratada. 


\subsection{Sistema de Tratamento de Água para Abastecimento}

\subsubsection{Caracterização dos Mananciais e dos Sistemas de Tratamento de Água Completo}

\subsubsection{Mananciais}

A fonte de água a ser utilizada no abastecimento público deve apresentar-se com qualidade e volume requerido. Em seu estado natural, a água apresenta certas propriedades físicas, químicas, biológicas e microbiológicas. A escolha do manancial deve obedecer critérios relativos ao uso a que se destina, porém deve-se tomar ações de modo a evitar que o mesmo sofra alterações e com isso torne inviável a tecnologia de tratamento adotada.

Teoricamente, a água residuária pode tornar-se água potável devido a evolução tecnológica, porém sabe-se que economicamente nem sempre pode-se tratar qualquer tipo de água.

O Conselho Nacional do Meio Ambiente (CONAMA), através da Resolução N. ${ }^{\circ} 20$ classificou as águas no Brasil e para cada uma dessas classes estão estabelecidos limites dos parâmetros de qualidade. De acordo com a classe da água é possível indicar quais as possíveis alternativas de tratamento que poderão ser empregadas a fim de torná-la potável.

As características biológicas normalmente são avaliadas pelo número de coliformes fecais sendo estes indicadores de contaminação por patogênicos. A água é utilizada como veículo por protozoários, bactérias e vírus, que podem causar doenças gastrointestinais. As algas além de causar sérios problemas operacionais no tratamento de água, em alguns casos, podem causar sabor e odor na água.

Do ponto de vista sanitário, as características físicas apresentam pequena importância, porém elas podem ser determinantes na escolha da tecnologia de tratamento. As principais características físicas são: turbidez (número e tamanho das partículas), cor aparente e cor verdadeira, sabor e odor, temperatura e condutividade. 
A presença de alguns elementos ou compostos químicos podem inviabilizar o uso de certas tecnologias, exigindo que o tratamento faça uso de técnicas específicas de modo a garantir a saúde da população que será abastecida.

Um problema que vem se agravando ao longo dos anos é a ocupação desordenada, com o uso inadequado do solo nas proximidades dos mananciais, existindo uma legislação que permite ao poder público intervir nessas áreas, sendo, contudo, a fiscalização precária.

A poluição dos mananciais ocasiona aumento no custo da água tratada, pois o tratamento exige maior consumo de produtos químicos e tecnologias mais avançadas.

Pior que ter o custo da água elevado decorrente de nossos mananciais encontrarem-se comprometidos é saber que segundo dados do Instituto Brasileiro de Geografia e Estatística (IBGE), citados por Luiz (1997), cerca de 58\% dos municípios brasileiros não têm água tratada, o que aumenta os índices de doenças infecciosas.

Na Tabela 1 são apresentados dados sobre três bacias hidrográficas do Estado de São Paulo. Esses dados mostram o quanto nossos rios estão sendo poluídos, o baixíssimo número de cidades que tratam seu esgoto e quantas dessas cidades estão captando água para abastecimento.

Tabela 1: Classificação das Bacias dos rios Atibaia, Piracicaba e Mogi-Guaçu, com o número de cidades pertencentes à Bacia, quantas tratam o esgoto e quantas captam água para abastecimento e quantidade de lançamento de poluentes

\begin{tabular}{|l|c|c|c|c|}
\hline \multicolumn{1}{|c|}{ Bacia } & $\begin{array}{c}\text { N. }^{\circ} \text { de cidades } \\
\text { na Bacia }\end{array}$ & $\begin{array}{c}\text { N. }^{\mathbf{o}} \text { de cidades } \\
\text { que tratam } \\
\text { esgoto }\end{array}$ & $\begin{array}{c}\text { Lançamento de } \\
\text { poluentes } \\
\text { (ton./dia) }\end{array}$ & $\begin{array}{c}\text { N. }{ }^{\circ} \text { de cidades } \\
\text { que captam } \\
\text { água para } \\
\text { abastecimento }\end{array}$ \\
\hline Atibaia & 10 & 3 & 39 & 10 \\
\hline Piracicaba & 16 & 2 & 86 & 2 \\
\hline Mogi-Guaçu & 38 & 7 & 65 & 38 \\
\hline
\end{tabular}

Fonte: Jornal O Estado de São Paulo(07/09/97) 


\subsubsection{Sistemas de Tratamento de Água Completo}

Para a utilização da água como consumo, esta necessita apresentar-se potável (não apresentar microorganismos patogênicos e nem substâncias orgânicas ou inorgânicas em teores que prejudiquem o ser humano). Caso a água da fonte não apresente-se desta forma, então ela deverá ser tratada.

Somente um estudo detalhado da qualidade da água bruta é que fornecerá os elementos necessários para a definição da tecnologia apropriada para torná-la potável.

O tratamento mais comum no Brasil é o tratamento completo ou convencional. Contudo existem também vários processos tecnológicos empregados no país, tais como: filtração direta ascendente, filtração direta descendente e filtração lenta (sem coagulação química, pouco difundida no país). A Figura 5 mostra a classificação das diversas tecnologias empregadas no tratamento da água para

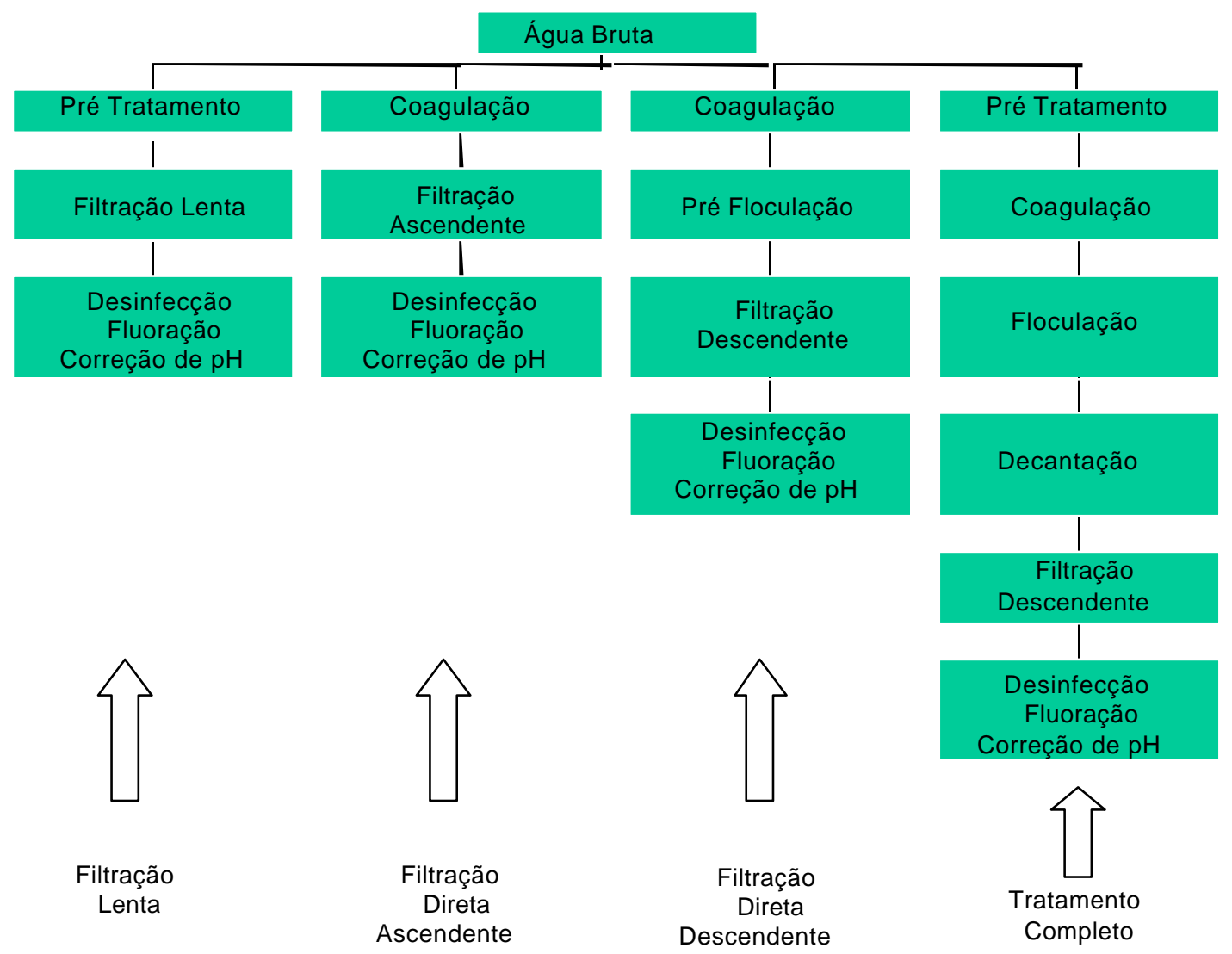

abastecimento.

Figura 5: Classificação das tecnologias de tratamento de água para consumo humano

Fonte: DI BERNARDO ( 1993) 
O processo de tratamento de água nas ETA completa constitui-se basicamente de 5 etapas: coagulação, floculação, decantação, filtração e desinfecção. Embora essas ETA sejam concebidas de maneira semelhante, diferenças de projeto e de produtos químicos empregados podem ser encontradas, acarretando particularidades às diversas estações.

A seguir descreve-se cada etapa do processo de tratamento de água completo.

\subsection{Coagulação}

$\mathrm{Na}$ água há presença de impurezas as quais encontram-se carregadas superficialmente com cargas negativas, o que impede o seu aglutinamento. Para conseguir sua remoção é necessário a aplicação de coagulantes (normalmente sulfato de alumínio ou cloreto férrico) os quais agem de forma que neutralizam essas cargas, possibilitando a aproximação de partículas que deverão ser removidas no decantador ou flotador.

O processo de coagulação é muito rápido, variando desde décimos de segundos a cerca de 100 segundos, dependendo do $\mathrm{pH}$, temperatura, quantidade de impurezas.

A coagulação é resultado da ação de 4 mecanismos distintos: compressão da camada difusa; adsorção e neutralização de cargas; varredura e formação de ponte.

O mecanismo de compressão da camada difusa ocorre quando há aumento de íons de cargas contrárias, aumentando a força iônica, o que faz com que, para manter-se neutra , a camada difusa tenha seu volume reduzido.

A adsorção e neutralização de cargas são causadas pelas interações entre coagulante - coloide, coagulante - solvente e coloide - solvente. Este mecanismo é muito importante quando a tecnologia empregada é de filtração direta, onde não existe necessidade de formação de grandes flocos.

$\mathrm{Na}$ varredura há a formação excessiva de precipitados de forma que os coloides são aprisionados nos mesmos. Em estações que empregam o tratamento completo este mecanismo é o mais recomendado, pois os flocos formados são bem 
maiores e apresentam velocidades de sedimentação relativamente altas, se comparados com o anterior.

Existem compostos orgânicos que apresentam característica de formação de pontes e atuam como coagulantes.

A garantia da qualidade do produto químico empregado permite maior segurança quanto à qualidade final da água. À medida que empregam-se produtos impuros ou mesmo com altos índices de rejeitos pode ocasionar prejuízo à água tratada, muitas vezes havendo necessidade de empregar dosagens muito superiores à dosagem ótima.

A definição de qual produto empregar é realizada através de ensaios em laboratório, assim como a dosagem necessária. Um método bastante empregado para a determinação das dosagens ótimas dos coagulantes a serem empregados é o "jar test", sendo também empregado para determinação de parâmetro básico na elaboração do projeto de uma estação de tratamento de água. Por este ensaio determina-se a condição ótima de floculação de uma determinada água caracterizada através do tempo e agitação necessária, para tal floculação.

\subsection{Floculação}

Após a aplicação do coagulante é feita uma mistura rápida de forma a possibilitar a distribuição uniforme do coagulante, possibilitando que todas as partículas tenham contato com as espécies hidrolisadas. Posteriormente a esta mistura segue-se uma mistura lenta, a qual denomina-se floculação.

Durante a floculação procura-se promover o maior número possível de encontros entre as partículas e a formação de partículas maiores, denominadas flocos, para que sejam eficientemente removidas no decantador.

O gradiente médio de velocidade e o tempo de floculação são parâmetros importantes para que a floculação seja bem sucedida, causando uma boa agregação e formação dos flocos. Com agitação muito intensa os flocos poderão sofrer ruptura devido às forças de cisalhamento. 


\subsection{Decantação}

A sedimentação é um fenômeno físico em que as partículas suspensas apresentam movimento descendente em meio líquido de menor massa específica, devido à ação da gravidade. O decantador é o responsável pela clarificação da água.

A maioria dos flocos formados nos floculadores sedimentam no decantador, porém interferências como canal de distribuição de água floculada, distribuição de água na entrada dos decantadores, ressuspenção, vento, curtos-circuitos, turbulência, canal de coleta de água decantada entre outros fatores prejudicam esta etapa permitindo que os flocos passem para os filtros, provocando diminuição da carreira de filtração.

Com o intuito de aumentar a taxa de escoamento superficial dos decantadores desenvolveu-se o decantador de alta taxa, constituído de sedimentadores que podem ser dutos de seção quadrada, circular, ou placas planas. A introdução deste tipo de decantador possibilita diminuir a área do decantador ou utiliza-lo para uma vazão maior, sem alterar as dimensões do mesmo.

As impurezas retidas no decantador podem ser armazenadas no fundo do tanque, normalmente aí permanecendo por cerca de 2 meses ou removidas diariamente utilizando-se de raspador de lodo. Grande parcela do resíduo sedimentado no decantador é lançado em corpo d'água, sendo o primeiro caso mais grave, pois as impurezas permanecem longo tempo em contato com a água (podendo neste período haver o desprendimento de metais pesados na água, por exemplo) e o lodo fica mais concentrado, dificultando sua assimilação pelo corpo receptor.

\subsection{Flotação}

A flotação caracteriza-se pela ascensão das partículas suspensas, pela aderência de bolhas de ar às mesmas, tornando-as de menor massa específica que o meio onde se encontra. Quanto maior o ângulo de contato entre a bolha e a partícula mais eficiente resulta a aderência entre ambas. Este fenômeno propicia a separação das fases líquida e sólida, clareando o meio líquido. 
Segundo estudos realizados por REALI (1991), para efetuar a flotação em partículas presentes nas águas superficiais, é necessário realizar previamente a coagulação/floculação adequadas das mesmas.

O emprego da flotação em tratamento de água para abastecimento, no Brasil, é um processo inovador, apresentando resultados muito bons para águas com cor elevada e presença de algas.

\subsection{Filtração}

Esta etapa é a barreira sanitária da água, na qual as impurezas são retidas pela passagem da água em meio poroso.

Os filtros denominados rápidos são aqueles em que predominam a ação de profundidade. Após um certo tempo de operação do filtro ocorre um aumento de partículas nos interstícios e uma diminuição destes, o que ocasiona um aumento da velocidade intersticial e das forças cisalhantes de modo a arrastar as partículas para as camadas inferiores. Com o decorrer da carreira de filtração, pode acontecer o transpasse (momento em que as impurezas são carreadas para fim da camada filtrante elevando a turbidez da água filtrada). O ideal seria retirar o filtro de operação quando simultaneamente ocorressem o transpasse e a perda de carga igualasse à carga hidráulica disponível.

A lavagem dos filtros pode ser feita somente com água no sentido ascensional, lavagem auxiliar superficial com tubulação fixa ou torniquetes hidráulicos e lavagem com água no sentido ascensional, com insuflação de ar seguido de lavagem de água no sentido ascensional ou insuflação de ar e introdução simultânea de água no sentido ascensional.

A água de lavagem pode ser proveniente de reservatório elevado, de bombeamento direto ou dos demais filtros em operação.

A recuperação da água de lavagem de filtros pode trazer muitas vantagens para o sistema, pois é uma parcela considerável de água aduzida que não será descartada e na mesma está incorporado produtos químicos empregados no processo, de forma a existir também recuperação de uma fração destes, sem contar na 
diminuição de custos com energia elétrica por diminuir adução. Estudos sobre a qualidade desta água devem ser desenvolvidos. Para a recuperação de água de lavagem é necessário construir tubulações que retornem essa água ao poço de chegada da água bruta. Ainda são poucas as estações que têm feito o aproveitamento da água de lavagem dos filtros, retornando-a ao processo. Em sua maioria a água é lançada em corpo d'água. O reuso desta água poderia estar possibilitando economia de produto químico, de energia e da própria água.

\subsection{Desinfecção}

De acordo com DI BERNARDO (1993) a desinfecção tem por objetivo eliminar os microorganismos patogênicos presentes na água, sendo um processo seletivo, ou seja, não destrói todos os seres vivos presentes na água e nem elimina completamente os organismos patogênicos. Somente a esterilização consegue eliminar completamente as formas vivas presentes na água.

Alguns agentes desinfetantes podem ser citados: cloro, ozônio, peróxido de hidrogênio, bromo, iodo, permanganato de potássio, calor e radiação ultravioleta.

As estações de tratamento de água normalmente utilizam o cloro como desinfetante.

Vários estudos envolvendo o cloro tem sido desenvolvidos devido a preocupação com a formação de compostos organo-halogenados, dos quais o mais importante subproduto é o trihalometano (é formado pela substituição de átomos de hidrogênio por átomos de cloro, bromo ou iodo devido à existência na água de ácidos húmicos, fúlvicos e himatomelânicos), pois esses compostos são indutores de câncer. Os estudos estão sendo feitos de modo a se descobrir desinfetantes alternativos que não provoquem danos à saúde da população, porém ainda pouco é provado em relação aos reais benefícios da troca de desinfetante, havendo possibilidades de formação de outros compostos também malignos com o emprego do novo desinfetante.

Estudos realizados com o cloro determinaram que o $\mathrm{pH}$ é um fator importante na desinfecção. Com $\mathrm{pH}<6$ o cloro apresenta maior poder de desinfecção, sendo que 
acima deste valor de $\mathrm{pH}$ tende a diminuir a eficiência. Outros fatores relevantes são temperatura e tempo de contato.

Existe uma dosagem de cloro para a qual deveria ocorrer a oxidação de toda amônia disponível, matéria orgânica e inorgânica denominada de "break point". A partir deste ponto o aumento da dosagem de cloro implicará em aumento correspondente do teor de cloro residual livre. O desconhecimento desta dosagem pode prejudicar a qualidade da água servida, pois o cloro ainda estará reagindo com o nitrogênio amoniacal e provavelmente não existirá cloro residual para garantia da não contaminação dessa água.

\subsection{Serviço de Abastecimento de Água}

As empresas de saneamento iniciaram-se como repartições seguidas de departamentos e atualmente em sua grande maioria tornaram-se autarquias.

Segundo BRANCO (1995), Serviço Público é todo aquele prestado pela administração ou por seus delegados, sob normas e controles estatais, que garantem a sobrevivência e bem estar do indivíduo, a soberania e o desenvolvimento nacional, a segurança, a integridade nacional, o regime democrático, a ordem jurídica. Sabe-se que o gigantismo do estado centralizador torna ineficiente e quase inadministrável sua máquina executiva, enquanto as modernas técnicas de gestão demonstram a necessidade de reduzir as escalas, para assegurar a agilidade que o mundo moderno exige das instituições, dada a rapidez com que as mudanças e as inovações se processam.

No Brasil, com as acentuadas diferenças de renda entre os vários extratos, sociais é praticamente impossível prestar serviços públicos sem o subsídio às camadas mais pobres, o que é impraticável em uma "política de mercado". As capacidades aquisitivas não são iguais, enquanto as necessidades básicas o são.

AZEVEDO et al. (1995) definem concessão de serviço público como a transferência da prestação de um serviço público, por delegação contratual, feita pela administração a terceiro, que irá executá-lo por prazo certo e por sua conta e risco, mediante remuneração cobrada dos usuários (tarifa). 
Os serviços de saneamento podem ser institucionalizados como: departamento, autarquia ou empresa de economia mista. A seguir são descritos tópicos sobre cada um deles.

1. O Departamento é uma instituição que depende da Prefeitura, pois não tem autonomia financeira. As receitas entram para o caixa único do tesouro municipal e os servidores são regidos pelo regime jurídico único sendo contratados por concurso público. Não é permitido a apropriação de custos do sistema e nem a avaliação se o serviço é auto-sustentável pelas tarifas. O departamento não é ágil administrativamente.

2. A Autarquia possui maior autonomia administrativa e financeira em relação aos departamentos. Os servidores são regidos pelo regime jurídico único. Este tipo de instituição garante maior controle externo sobre balanço financeiro.

3. A Empresa de Economia Mista exige resultado financeiro positivo como empresa privada e permite efetivo controle de desempenho econômico - financeiro. Seus servidores são regidos pela Consolidação das Leis Trabalhistas (CLT), mas admitidos por concursos públicos, sendo que os encargos sociais são maiores do que sobre as autarquias.

A Lei Federal N. ${ }^{\circ} 8987$ (1995) - Lei das Concessões, em última análise regulamenta o artigo 175 da Constituição Federal. Esta Lei exige, de maneira expressa, que o contrato de concessão seja precedido de licitação, na modalidade de concorrência. O julgamento da licitação prevê no art. 15 que seja exclusivamente baseado em critérios de menor valor da tarifa; maior oferta pela outorga da concessão; combinação dos critérios anteriores, desde que a sua forma de cálculo esteja claramente estabelecida no Edital. Esta Lei firma que o poder concedente poderá intervir na concessão com o fim de assegurar a adequação da prestação do serviço, bem como o cumprimento das cláusulas contratuais regulamentares e legais pertinentes. 


\subsubsection{Empresa Pública e Privada}

O serviço de abastecimento de água público no Brasil encontra-se em sua maioria trabalhando de modo corretivo, ou seja, são realizados serviços somente depois de ter acontecido o problema. O sistema opera mais de modo reativo do que proativo, de forma que o planejamento dos serviços praticamente não são atendidos, realizam-se ações emergenciais, ou seja, será executado o caso mais grave.

A grande dificuldade encontrada na maioria das empresas de água é o fato de o diretor ser um cargo de confiança do prefeito, existindo um rodízio grande, no qual muitas vezes os programas não tem continuidade e as prioridades são dadas de acordo com os interesses políticos. Esse tipo de acontecimento muitas vezes provoca o sucateamento do serviço público.

Pode-se dizer que empresa de abastecimento de água bem administrada é um serviço que gera capital, pois ela produz um produto consumido por toda população sem restrição de classe social. A taxa ou tarifa cobrada pelo serviço inclui gastos com a produção da água tratada e investimentos para melhoria do sistema de captação, adução, tratamento, armazenamento e distribuição de água. Por ser um produto consumido por toda população é difícil imaginar que empresas como essas possam ficar em "déficit".

Como o retorno econômico desse empreendimento é reconhecidamente seguro, muitos estão tentando pegar uma fatia do mercado. Mas se o serviço público bem gerenciado é auto-suficiente porquê transferir a concessão de empresas públicas para a mão de empresas particulares?

A existência de críticas por parte da sociedade quanto a qualidade e a confiabilidade do serviço prestado é muito importante, pois à medida que os serviços são cobrados, existe uma tendência de trabalho com maior rigor.

A empresa privada apresenta grande diferença da empresa pública: o lucro. Os investidores, com o intuito de aumentar cada vez mais seu capital sem desrespeitar os projetos estabelecidos no contrato de concessão, procuram aplicar programas de gerenciamento na empresa de forma a diminuir os desperdícios, pois estes nada mais são do que algo que se deixou de ganhar. 
Normalmente empresas estrangeiras incorporam ao serviço seu próprio corpo técnico; assim como também sua tecnologia, o que usualmente não se faz necessário devido encontrar-se no país bons profissionais na área e apresentarmos condições sócioeconômicas diferenciadas do país de onde vem estas empresas (provavelmente originárias de países do chamado primeiro mundo).

NEGREIROS (1997) relatou a experiência vivida pela cidade de Limeira, cuja concessão foi transferida para a iniciativa privada. Acredita-se que o nível de exigência por parte dos consumidores seja maior pelo fato deste possuir maior facilidade de identificar um interlocutor ao qual tenha acesso imediato. O serviço é prestado pelo consórcio Águas de Limeira estabelecido entre a Companhia Basileira de Projetos e Obras (CBPO) e a francesa Suez Lyonnaise des Eaux que atuarão no serviço de água de Limeira por 30 anos. Vários questionamentos foram levantados sobre a licitação e aspectos ligados ao contrato com a Águas de Limeira, porém segundo pesquisas de opinião pública a empresa está aprovada do ponto de vista técnico, todavia, constatando-se insatisfação com relação ao aumento das tarifas em determinadas faixas de consumo. A fiscalização da realização dos serviços de tratamento e abastecimento da cidade são de responsabilidade da administração municipal. Dois anos e meio após o início da gestão, $100 \%$ da população é abastecida com água e 92,5\% de coleta de esgoto. A empresa Águas de Limeira, admiti que a situação de cobertura da rede de água e de coleta de esgoto de Limeira não era ruim. Reduziu-se as perdas de água de $27 \%$ para $25 \%$. Os funcionários foram reduzidos e estes encaminhados para desempenhar outras atividades na prefeitura municipal. Está sendo desenvolvido pesquisa sobre a utilização de polifosfato de sódio com o objetivo de solucionar os problemas das águas vermelhas ou turvas resultantes do contato com a corrosão provocada nas redes de ferro. A empresa possui um laboratório móvel para realizar o controle de qualidade de água junto ao cliente. Os dirigentes da Águas de Limeira esperam conseguir com esta experiência novas concessões no Brasil.

A Associação Nacional dos Serviços Municipais de Saneamento (ASSEMAE) e a Federação Nacional dos Urbanitários (FNU/CUT) fizeram um relato em novembro de 1996 sobre as concessões privadas, no qual criticam as empresas de terem interesse somente em cidades grandes e que apresentem os 
sistemas relativamente consolidados. Levantam as dificuldades das empresas públicas para conseguirem financiamentos junto à Caixa Econômica Federal e ao Banco Nacional de Desenvolvimento Econômico e Social, pois alguns casos comprovam que tais instituições estão forçando a privatização dos serviços. Nesse relato os autores afirmam que não existe interesse por parte das empresas concessionárias privadas em assumir o passivo social, apenas lhes interessa o lucro. Outra questão levantada é sobre o problema da falta de recursos federais para o setor. Os mesmos autores mencionam que o governo gastou menos que o previsto no ano de 1995, ou seja o real problema está em como são gastas tais verbas, sabido que as mesmas existem. A concessão de Limeira é apontada pelas irregularidades no projeto de concessão e pela elevação da tarifa, assim como o fornecimento de água amarela (ressalta-se que a água fornecida anteriormente à concessão já apresentava tais características). Em Buenos Aires, a concessão do serviço de água foi cedida para a empresa francesa Lyonnaise des Eaux, a mesma que opera o serviço de Limeira, sendo que nessa cidade existem denúncias de superfaturamento, violação reiterada do contrato de concessão e mau cumprimento das funções públicas do ente regulador. $\mathrm{Na}$ França, empresas de saneamento corromperam ministros e políticos em troca das concessões dos serviços de água. Segundo radiografia apresentada, as empresas que buscam as concessões visam lucros em empresas públicas que já tenham uma boa infra-estrutura, não importando muito os meios para sua conquista.

GOLDFINCH (1998) revisou experiências de algumas autoridades da água que abraçaram o conceito de privatização e uma prática de gerenciamento alternativa, que ficaram conhecidas como corporações e enfatizam a importância de vantagens indiretas de melhorar o abastecimento de água potável seguro e confiável, particularmente os aspectos econômicos da melhoria da saúde pública. O assunto descrito pelo autor relata experiência vivida pelo Reino Unido e Austrália. O Reino Unido transferiu suas indústrias da água para empresas privadas e todos os negócios foram situados sobre os mesmos regimes regulatórios. Na Austrália o governo introduziu a competição dentro de suas operações.

A partir das reformas instituídas nesses países, o autor conclui que: "O Reino Unido e a Austrália parecem não ter ainda produzido vantagens para os consumidores como esperava o Governo, e é considerado que poderia ser 
inapropriado para o presente momento adotá-los como modelos de reformas de indústrias de abastecimento de água, especialmente em países em desenvolvimento. Das vantagens esperadas em decorrência das reformas, pode-se relatar principalmente o custo para o consumidor da água e pequenas considerações têm sido dadas às incontáveis vantagens de melhoras adequadas, abastecimento de água potável e confiável para as comunidades. Os procedimentos gerenciais mais efetivos são aqueles que envolvem diretamente os beneficiários e usuários do serviço de água. Se necessária a privatização o Governo deveria continuar controlando e dirigindo todos os aspectos de gerenciamento, operação e manutenção do trabalho. As autoridades deveriam também ser diretamente responsáveis pela qualidade da água, fazendo acompanhamento desta em todas as torneiras do sistema de abastecimento de água".

\subsection{A Pesquisa Tecnológica e Científica em ETA Convencionais e a Transferência de Experiências}

Ao longo dos anos várias pesquisas ligadas ao tratamento de água para abastecimento foram e estão sendo desenvolvidas por Instituições como Universidade de São Paulo - Escola de Engenharia de São Carlos, Universidade de Campinas, entre outras.

As cidades envolvidas nesta dissertação estudo apresentam-se próximas a tais universidades, o que possibilita o acesso a novas tecnologias e o emprego dos resultados de pesquisas de forma a melhorar a eficiência do tratamento da água.

Embora os responsáveis pelos serviços de tratamento disponham da facilidade e proximidade de acesso a tais instituições de pesquisa, sabe-se que poucos fazem uso do benefício de troca de informações.

Com o intuito de mostrar que os estudos estão sendo realizados e que poderiam ser incorporados às estações de tratamento de água, é apresentado, a seguir, um breve histórico dos trabalhos de mestrado e doutorado defendidos pelo Departamento de Hidráulica e Saneamento da EESC-USP. Nas pesquisas citadas estão apresentados os objetivos e as conclusões, ressalta-se que para maiores 
informações sobre o estudo o leitor deverá ler o trabalho original, cujas referências estão mencionadas no final desta dissertação.

\subsubsection{Coagulação e Floculação}

Estudos realizados por PENNA (1984) sobre a influência da mistura rápida hidráulica na floculação de águas de abastecimento, "mostraram que o ressalto hidráulico pode funcionar eficientemente como uma unidade de mistura rápida para a coagulação de águas de abastecimento. Numa unidade desse tipo, deve-se procurar lançar o produto químico coagulante de maneira mais uniforme possível. Nas estações de tratamento de água, a variação da vazão poderá alterar sensivelmente a posição de início do ressalto, modificando assim, a posição de lançamento do coagulante em relação ao ressalto. Concluiu-se também que o aumento do número de Froude a montante do ressalto produz um aumento da intensidade de turbulência que ocorre no mesmo, provocando uma melhora nas condições de mistura, que faz aumentar a eficiência do processo de coagulação. Entretanto, não há necessidades de se ter um escoamento com valores elevados do número de Froude para se obter uma coagulação eficiente. Percebe-se também que o aumento da vazão da água que passa pelo ressalto, para um mesmo número de Froude, altera as condições de mistura e também a eficiência do processo de coagulação indicando que o número de Froude não é o único parâmetro hidráulico envolvido no processo de mistura no ressalto".

MENDES (1989) estudou a coagulação e a floculação de águas sintéticas e naturais com turbidez e cor variáveis. Com base no trabalho realizado o autor concluiu que:

1. “A construção de diagramas de coagulação segundo a metodologia proposta por MENDES (1989), constitui em ferramenta de grande utilidade para o projeto e operação de sistemas de tratamento de água, evidenciando as faixas ótimas de dosagens de coagulante e $\mathrm{pH}$ de coagulação que podem ser empregados de forma a minimizar os custos de operação e maximizar as eficiências do tratamento;

2. É necessária a obtenção de bons resultados de coagulação para posterior floculação e sedimentação ou filtração direta, caracterizadas por faixas de $\mathrm{pH}$ de coagulação e dosagens de sulfato de alumínio bastante distintas; 
3. A dosagem ótima de sulfato de alumínio é decrescente com o aumento dos valores de $\mathrm{pH}$ de coagulação variando entre 4,0 e 5,0 para a coagulação no mecanismo de adsorção-neutralização e águas com turbidez e/ou substâncias húmicas;

4. Para esse mesmo caso, quanto maior for a concentração das partículas coloidais, maior é a amplitude de dosagens de sulfato de alumínio que podem ser empregadas e maiores as eficiências de remoção dos flocos formados por sedimentação para um dado valor de $\mathrm{pH}$;

5. As partículas coloidais causadoras de turbidez ou cor verdadeira podem ser restabilizadas por reversão de suas cargas superficiais, provocada por um excesso de dosagem de sulfato de alumínio quando emprega-se o mecanismo de adsorçãoneutralização;

6. Em outro mecanismo de coagulação, conhecido como varredura, caracterizase uma região do diagrama de coagulação onde são necessárias dosagens de sulfato de alumínio mais elevadas, porém, proporcionando a criação de flocos com melhores características de sedimentabilidade quando comparado com o mecanismo de adsorção-neutralização;

7. A região característica do mecanismo de varredura manifesta-se em amplas faixas de $\mathrm{pH}$ e dosagens de sulfato de alumínio. $\mathrm{O}$ aumento da dosagem de coagulante implica num alargamento da faixa ótima de valores de $\mathrm{pH}$ de coagulação e, ao contrário do observado no mecanismo de adsorção-neutralização, não ocorre a possibilidade de restabilização das partículas coloidais causadoras de cor verdadeira e/ou turbidez por uma superdose de coagulante mantendo-se fixo o valor do $\mathrm{pH}$ de coagulação;

8. A coagulação de águas contendo turbidez e/ou substâncias húmicas pelo mecanismo de varredura apresenta uma relação não estequiométrica entre a concentração de partículas coloidais e a dosagem de coagulantes;

9. $\mathrm{O}$ pH ótimo de coagulação de águas contendo altos teores de substâncias húmicas e turbidez baixa manifesta-se em valores menores que para as águas com turbidez alta e baixos teores de substâncias húmicas, para ambos os mecanismos de coagulação; 
10. As operações de filtração direta devem ser executadas com o emprego do mecanismo de adsorção-neutralização, na região denominada por "corona", caracterizada entre os valores de $\mathrm{pH}$ variando entre 5,5 e 7,0;

11. A variação do gradiente de velocidade para a mistura rápida entre valores de $500 \mathrm{e} 1200 \mathrm{~s}^{-1}$ teve pouca influência sobre os resultados, porém, o período de agitação não deve se estender por valores superiores a 10 segundos, principalmente quando a operação de coagulação dá-se pelo mecanismo de varredura;

12. A operação de coagulação no mecanismo de varredura requer um período de floculação significativamente inferior que o necessário para a obtenção de uma mesma eficiência de remoção de turbidez e/ou cor aparente por sedimentação quando emprega-se o mecanismo de adsorção-neutralização;

13. Para cada período de floculação $(T)$ existe um único gradiente de velocidade ótimo $\left(\mathrm{G}^{*}\right)$, que maximiza a remoção de turbidez e/ou cor aparente por sedimentação e quando T tende para o infinito, $\mathrm{G}^{*}$ tende para $\mathrm{G}^{\text {' "; }}$

Pesquisa realizada por COSTA (1992) sobre o uso de polímeros naturais (amidos de batata, de mandioca e de araruta) como auxiliares de floculação com base no diagrama de coagulação do sulfato de alumínio foi desenvolvida para dois tipos de água: uma com turbidez alta e cor verdadeira baixa, e outra com turbidez baixa e cor verdadeira alta. "Em tal estudo comprovou-se que a remoção da turbidez ou cor aparente, através da sedimentação em determinada velocidade é maior quando a coagulação é realizada no mecanismo de varredura do que quando é realizada no mecanismo de adsorção-neutralização. Verificou-se que para os dois tipos de água os flocos produzidos com o uso de sulfato de alumínio como coagulante e polímeros como auxiliares apresentaram aspecto mais denso e compacto do que quando usado somente o sulfato de alumínio. Uma observação importante foi que a vantagem da aplicação de polímeros naturais para os dois tipos de água estudados foi mais notada na região da varredura que na região de adsorção-neutralização. Notou-se que o emprego do polímero natural foi mais vantajoso para a água com turbidez baixa e cor verdadeira elevada, sendo que o amido de mandioca apresentou melhores resultados. A eficiência dos polímeros apresentou-se superior com velocidades menores que 2 $\mathrm{cm} / \mathrm{min} "$ 
CAMPOS (1992) estudou a influência das características geométricas do agitador mecânico de paletas giratórias paralelas ao eixo vertical na potência introduzida na água e obteve as seguintes conclusões:

1. "O valor de $C_{D}$ da paleta, na região em que este independe do número de Reynolds, está coerente com os valores encontrados na literatura;

2. O valor do parâmetro $\mathrm{K}$ varia segundo a rotação e a configuração do agitador;

3. A potência obtida através da utilização de $\mathrm{K}$ com valor constante e igual a 0,25 não é igual à potência que o agitador realmente está introduzindo na água; portanto o gradiente de velocidade $(\mathrm{G})$ necessário para a floculação não corresponderá à rotação dos equipamentos em uma estação de tratamento, já que os mesmos são decorrentes de estudos realizados em laboratório, em que o valor $\mathrm{G}$ é obtido experimentalmente;

4. A potência total introduzida por um agitador com mesmo número de braços e algumas paletas por braço, não é a soma da potência de cada paleta, obtida individualmente no mesmo reator, sendo esta última maior que a primeira;

5. A potência total introduzida por um agitador de 2 ou 4 braços nem sempre é 2 ou 4 vezes aquela introduzida por um agitador de 1 braço, com o mesmo número de paleta por braço, sendo esta última maior que a primeira;

6. Para diferentes agitadores e mesma velocidade de sedimentação obtém-se diferentes valores da eficiência de remoção de turbidez e cor aparente, quando as demais condições (gradiente de velocidade, tempo de floculação, temperatura da água) permanecem constantes".

PAIXÃO (1996) estudou a coagulação, floculação e sedimentação de água com turbidez ou cor elevada, utilizando polímero sintético como auxiliar de floculação. "Este trabalho teve como objetivo obter diagramas de coagulação para duas águas preparadas a partir de caulinita e substâncias húmicas, através da coagulação, com sulfato de alumínio; propor metodologia para avaliar o uso combinado de sulfato de alumínio como coagulante primário e polímeros sintéticos como auxiliares de floculação das duas águas, levando-se em conta, o pH e a dosagem de coagulante e comparar os resultados obtidos durante os ensaios de floculação com e sem a utilização de diferentes polímeros sintéticos auxiliares de floculação. Os resultados deste trabalho propiciaram as seguintes conclusões: 
1. Pode-se confirmar, através dos diagramas de coagulação para ambas as águas, que existem duas regiões onde a coagulação é eficiente, sendo que as dosagens de coagulantes em cada região são bem distintas;

2. Para ambas as águas, as dosagens de coagulante na região de adsorçãoneutralização são bem inferiores quando comparadas com as dosagens de coagulantes na região de varredura;

3. A eficiência de remoção de turbidez ou cor aparente, através da sedimentação, em determinada velocidade é maior quando a coagulação é feita no mecanismo de varredura do que quando no mecanismo de adsorção-neutralização para ambas as águas;

4. Para água com turbidez alta e cor baixa, o pH ótimo de coagulação-floculação é mais baixo quando comparado com o pH ótimo de coagulação-floculação para água com cor alta e turbidez baixa, para a região de varredura;

5. A partir dos pontos ótimos de dosagem de sulfato de alumínio extraídos dos diagramas de coagulação pode-se obter para a mesma eficiência uma maior redução da dosagem de sulfato de alumínio com o emprego de polímero como auxiliar de floculação;

6. Mostrou-se plenamente viável e aplicável a metodologia proposta para uso combinado de sulfato de alumínio como coagulante primário e polímeros sintéticos como auxiliares de floculação de ambas as águas estudadas, levando-se em conta o $\mathrm{pH}$ e a dosagem de coagulante;

7. Ficou provado que é possível obter uma mesma eficiência de remoção de turbidez ou cor com uma redução da dosagem de sulfato de alumínio com o uso combinado de pequenas dosagens de polímero $(<1,0 \mathrm{mg} / \mathrm{l})$;

8. Foi observado que a medida que se aumentava a velocidade de sedimentação, ocorria também a necessidade de aumento do valor de dosagem ótima de polímero para manter a eficiência em ambas as águas estudadas;

9. Para velocidade de sedimentação baixa $(0,8 \mathrm{~cm} / \mathrm{min})$ o emprego ou não de polímero como auxiliar de floculação não influencia na redução de turbidez ou cor das águas estudadas; 
10. Foi observado que doses de polímero em excesso $(>1,0 \mathrm{mg} / \mathrm{l})$ na maioria das vezes não causou nenhuma melhoria na eficiência de remoção de turbidez ou de cor nas águas estudadas".

\subsubsection{Decantação e Flotação}

REALI (1984) desenvolveu pesquisa aplicando a flotação por ar dissolvido para tratamento de águas de abastecimento. "Tal estudo teve o objetivo de projetar, executar e operar uma instalação piloto destinada à clarificação de águas para abastecimento. Foram analisados os seguintes aspectos: comportamento hidráulico da câmara de flotação, utilizando-se $\mathrm{NaCl}$ como traçador; relação entre a qualidade de ar liberado na câmara de flotação com o tempo de detenção na câmara de saturação e influência da taxa de escoamento superficial, da pressão e da porcentagem de vazão de recirculação na eficiência do processo de flotação. Os resultados obtidos permitiram concluir que:

1. Em certos casos, a flotação por ar dissolvido aplicado à clarificação de águas de abastecimento pode vir a se constituir em alternativa ao processo de sedimentação;

2. A eficiência da instalação piloto de flotação no que diz respeito à porcentagem de remoção de cor, turbidez e sólidos suspensos, apresentou certa relação com a turbidez da água bruta, de forma que, quanto maior se apresentava a turbidez da água bruta melhores eram os resultados de porcentagem de remoção por flotação;

3. O sucesso da clarificação das águas de abastecimento da cidade de São Carlos, S.P., por flotação por ar dissolvido, demostrou estar intimamente relacionado ao bom desempenho do processo de coagulação-floculação;

4. A altura do dispositivo de entrada da câmara de flotação utilizada nesta pesquisa influi sensivelmente na distribuição do fluxo no interior da mesma;

5. O dispositivo de mistura da recirculação pressurizada com o afluente da câmara de flotação pareceu ter influência marcante no desempenho da unidade de flotação; 
6. Os valores de vazão de recirculação que conduziram a maiores eficiências da flotação, para cada taxa de escoamento superficial e pressão estudadas, situaram-se sempre abaixo de $15 \%$ ".

CUNHA (1989) estudou o comportamento hidráulico e a eficiência na sedimentação de alta taxa, tendo como objetivo investigar a influência da configuração física dos decantadores de alta taxa, com relação à largura e à altura dos mesmos, sobre a eficiência de remoção de partículas floculadas, bem como a aplicabilidade de ensaios de coluna de sedimentação e a correlação de resultados para prever o desempenho de decantadores de alta taxa. Em vista dos estudos realizados apresentou as seguintes conclusões:

1. "Ficou evidenciado que a largura de sedimentadores de alta taxa não exerce influência sobre a eficiência na remoção de partículas floculadas;

2. As demais características físicas dos sedimentadores de alta taxa e a velocidade de sedimentação crítica mostraram-se adequadamente consideradas nos modelos teóricos, sem necessidade de limitações adicionais a respeito;

3. Outros parâmetros hidráulicos, tais como o número de Reynolds, não evidenciaram interferência sobre os resultados e portanto parecem dispensáveis as restrições quanto a seus valores eventualmente referidos na literatura técnica;

4. O desempenho dos sedimentadores de alta taxa na remoção de turbidez correspondeu ao de decantadores convencionais com taxas de aplicação até cerca de 10 vezes menores".

Estudos sobre a influência da taxa de aplicação superficial em uma instalação piloto de flotação por ar dissolvido por pressurização aplicada ao tratamento de água para abastecimento foram realizados em COELHO (1990). "Do ponto de vista operacional conclui-se que:

- quando se tem como variáveis a água bruta, condições de coagulação, taxa de aplicação superficial e tempo de detenção na unidade de floculação/flotação o sistema de flotação na faixa de valores de taxa de aplicação superficial estudada, não apresentou relação entre estas e a qualidade do efluente produzido;

- para os intervalos de taxa de aplicação superficial estudados, o sistema mostrou a mesma eficiência no que diz respeito a porcentagem de remoção de turbidez (56 a 
74\%), de cor aparente (75 a 92\%), de cor verdadeira (88 a 97\%) e a de sólidos suspensos totais $(73$ a $85 \%$ ) e a floculação adequada é um pré-requisito fundamental para obter-se bons resultados na flotação.

Sob o ponto de vista estatístico foram apresentadas as seguintes conclusões:

- a grande maioria das análises mostrou que a independência entre os parâmetros de qualidade da água bruta (turbidez, cor verdadeira, cor aparente e sólidos suspensos totais) e a taxa de aplicação superficial para variações entre 120 a 300 $\mathrm{m}^{3} / \mathrm{m}^{2}$ dia é uma possibilidade que não pode ser descartada no conjunto de dados utilizados, para intervalos de confiança de 95 a 99\%. A exceção para esta tendência geral pôde ser vista, quando se fez análise conjunta dos dados, para a porcentagem de remoção de cor verdadeira e sólidos suspensos totais, quando ocorreram decréscimo destas com aumento na taxa de aplicação superficial.

Concluiu-se também que a independência entre os parâmetros de qualidade da água bruta e tempo de detenção na unidade de floculação/flotação (15 a 30 minutos), é uma possibilidade que não pode ser descartada no conjunto de dados utilizados para intervalos de confiança de 95 a 99\%. A exceção para esta tendência foi quando se analisou a remoção de sólidos suspensos totais, quando ocorreu um decréscimo desta para um aumento no tempo de detenção, para a taxa de 180 $\mathrm{m}^{3} / \mathrm{m}^{2}$ dia”.

REALI (1991) pesquisou a concepção e avaliação de um sistema compacto para tratamento de águas de abastecimento utilizando o processo de flotação por ar dissolvido e filtração com taxa declinante. "Tal pesquisa teve como objetivo principal o projeto, construção e avaliação de um sistema compacto original para tratamento de águas de abastecimento que conjuga em uma só estrutura as unidades de floculação, flotação por ar dissolvido com recirculação pressurizada e filtração com taxa declinante. Para o desenvolvimento desta pesquisa, foram estabelecidos alguns passos intermediários que caracterizaram os seguintes objetivos:

- avaliar a eficiência de uma câmara de saturação com "recheio" composto por anéis de PVC, propondo para isso metodologia adequada;

- utilizando água artificialmente preparada com cor elevada e baixa turbidez, comparar as condições ótimas de coagulação obtidas através de ensaios convencionais de sedimentação ("jar test") com aquelas obtidas em ensaios 
realizados com uma unidade de flotação por ar dissolvido em escala de laboratório (flotateste);

- propor um equacionamento matemático que forneça bases teóricas para análise quantitativa dos principais parâmetros envolvidos no processo de flotação por ar dissolvido com recirculação pressurizada.

Os resultados obtidos propiciaram as seguintes conclusões:

- os ensaios efetuados com a instalação piloto comprovaram que o sistema proposto constitui alternativa tecnicamente viável para a clarificação da água do Ribeirão do Feijão - São Carlos/SP. A idéia de se conjugar numa só estrutura as unidades de floculação, flotação por ar dissolvido e filtração com taxa declinante resultou num sistema de clarificação original e bastante compacto. A pequena área em planta requerida pelo sistema se deveu ao bom aproveitamento dos espaços internos e ao fato de a flotação constituir um processo de alta taxa. Tais características de compacidade, permitiram que o sistema entrasse em regime de equilíbrio em intervalos de tempo relativamente pequenos (em torno de 1 hora). Entretanto, deve-se salientar que, devido ao pequeno tempo de detenção hidráulica em seu interior, o sistema demonstrou ser bastante sensível a variações bruscas na qualidade da água bruta e nas condições de coagulação, tendo exigido atenção especial do operador para tais fatores;

- o tipo de câmara de saturação proposto no presente trabalho (recheio composto de anéis de PVC) apresentou bom desempenho em toda a faixa de valores de taxa de aplicação superficial (entre 290 e $1060 \mathrm{~m}^{3} / \mathrm{m}^{2}$ dia) e de pressão (entre 200 a $490 \mathrm{kPa}$ ) estudadas. Comparando-se com a capacidade de saturação da câmara proposta por ZABEL $^{1}$, a referida câmara apresentou eficiência aproximadamente igual a $96 \%$. Além disso, constatou-se que sua operação, além de simples, também foi bastante eficiente no que concerne às conciliações de pressão relativamente pequenas que foram observadas ao longo do tempo;

- dentre os três tipos de floculadores testados, o floculador tipo 3 (mecanizado), aliado ao fornecimento de cerca de $10 \mathrm{mg}$ de ar/l de água bruta, apresentou as maiores vantagens do ponto de vista de desempenho da flotação. O tempo de 
detenção igual a 33 minutos forneceu os melhores resultados para água bruta com turbidez e cor aparente relativamente baixas (entre 10 e 16 uT e entre 30 e 60 mg/l em Pt-Co, respectivamente), sendo que nos testes efetuados com água bruta apresentando turbidez média de 27 uT e cor aparente média igual a $100 \mathrm{mg} / \mathrm{l} \mathrm{em}$ Pt-Co, a variação do tempo de detenção entre 15 a 25 minutos, não influiu significativamente no desempenho do sistema;

- foi possível a obtenção de condições satisfatórias de floculação adotando-se os floculadores tipo 1 (fluxo helicoidal + microbolhas de ar) ou tipo 2 (só microbolhas de ar), com tempo de detenção entre 20 e 33,3 min. E desde que fossem fornecidas quantidades de ar com valores maiores que $18 \mathrm{mg}$ de ar/l de água bruta, valor este, considerado grande se comparado aos $10 \mathrm{mg} / \mathrm{l}$ requeridos pelo floculador tipo 3 (mecanizado). Portanto, apesar de tecnicamente viável, o emprego dos floculadores tipo 1 e tipo 2 apresentou-se como opção desvantajosa em relação ao tipo 3. Através de comparação entre os resultados obtidos com os floculadores tipo 1 e tipo 2, conclui-se que a presença de fluxo helicoidal no interior da zona de floculação/flotação, juntamente com a presença de microbolhas de ar (floculador tipo 1), não resultou em benefício à floculação;

- dentre os três tipos de dispositivo de despressurização da recirculação investigados, o tipo A (registro de agulha) e o tipo B (orifícios posicionados no final da zona de floculação) demonstraram, igualmente, constituírem as melhores opções para o sistema, pois proporcionaram as maiores eficiências do processo de flotação por ar dissolvido;

- com relação à taxa de aplicação superficial na zona de flotação e filtração do sistema piloto, pode-se concluir que sob o ponto de vista operacional (análise dos conjuntos diários de ensaios) e para as condições gerais do estudo (qualidade da água bruta, condições de coagulação e tempo de floculação entre 20 e $300 \mathrm{~m}^{3} / \mathrm{m}^{2}$ dia), é uma possibilidade que não pode ser descartada no conjunto de dados utilizados, para intervalo de confiança de $99 \%$;

- em unidades de flotação/filtração existe a possibilidade de arraste de microbolhas de ar para o interior das unidades de filtração, dependendo da distribuição de

\footnotetext{
${ }^{1}$ ZABEL, T. The Advantages of Dissolved-Air Flotation for Water Treatment. Journal AWNA, 42-46,
} 
tamanho de bolhas presente na parte superior dos filtros, da taxa de filtração e da configuração do sistema. Entretanto, durante a operação do sistema objeto do presente estudo sob condições controladas de ensaio, não foi verificado aumento de perda de carga no leito filtrante devido ao arraste de microbolhas de ar, para um tempo máximo de operação igual a 6,4 h;

- a construção de cobertura sobre a instalação piloto foi fundamental, como medida preventiva à ação da chuva e do vento sobre a camada de lodo acumulado na superfície, além disso, constatou-se ser essencial a instalação de dispositivo "caça bolhas" no final da zona de floculação/flotação para se evitar a presença de bolhas grandes na zona de acumulação de lodo. Verificou-se que a presença de bolhas na superfície ocasionava a desestabilização da camada de lodo que, por sua vez, acarretava sérios prejuízos ao processo de filtração;

- tanto para a água preparada com cor elevada quanto para a água natural do Ribeirão do Feijão - São Carlos/SP constatou-se que para todas as dosagens de coagulante investigadas, o valor ótimo de $\mathrm{pH}$ de coagulação obtido através de testes de sedimentação ("jar test") foi diferente do valor ótimo de $\mathrm{pH}$ encontrado em testes de flotação (flotateste). Portanto, as condições ótimas de coagulação para o processo de flotação de águas de abastecimento devem ser obtidas através de flotateste ou, pelo menos, devem ser efetuados testes preliminares de flotação conjuntamente a testes de sedimentação para se saber se os resultados são ou não comparáveis;

- a obtenção de curvas de flotação, de maneira proposta no presente trabalho, demonstrou ser de grande valia para o estudo comparativo entre vários parâmetros relacionados ao processo de flotação, tais como $\mathrm{pH}$ de coagulação, dosagem de coagulante, quantidade de ar fornecida, entre outros;

- para água bruta preparada com cor elevada e baixa turbidez e dosagem de sulfato de alumínio entre 20 e $35 \mathrm{mg} / \mathrm{l}$, verificou-se que, de maneira geral, a coagulação realizada em pH baixo (entre 4,6 e 4,9) forneceu curvas de flotação com tendência bastante semelhante àquela apresentada pelas curvas de flotação obtidas em pH mais elevado (entre 6,55 e 6,7). Sendo que em ambas as regiões de coagulação o sistema 
apresentou eficiência de remoção de cor aparente por flotação aproximadamente constante e em torno de $90 \%$, para velocidade de flotação menores que 216 m/dia;

- para água preparada com cor aparente igual a 149 mg/l em Pt-Co e turbidez igual a 5,6 UT, a análise das curvas de flotação mostra que a dosagem de $30 \mathrm{mg} / \mathrm{l} \mathrm{de}$ sulfato de alumínio forneceu os melhores resultados de remoção de cor aparente tanto para $\mathrm{pH}$ em torno de 4,0 quanto para $\mathrm{pH}$ em torno de 6,6. Além disso, as referidas curvas de flotação mostraram que o valor ótimo da razão de recirculação encontrava-se próximo a $11 \%$ para pressão de saturação em torno de $392 \mathrm{kPa}$, resultando numa quantidade ótima de ar fornecida para a flotação, proximadamente igual a 9,9 mg/l, valor este bastante próximo aos $10 \mathrm{mg} / \mathrm{l}$ obtidos nos ensaios com a instalação piloto alimentada com água do Ribeirão Feijão".

COSTA (1996) realizou pesquisa sobre a sedimentação de partículas discreta em dutos utilizados na decantação de alta taxa considerando escoamento laminar nos trechos de transição e de perfil desenvolvido. "O presente trabalho teve como objetivos: generalizar a modelação matemática existente para escoamento laminar no trecho de transição em dutos de seção quadrada ou retangular com qualquer geometria, inclinados com ângulos diferentes de $0^{\circ}$ com o plano horizontal; adaptar a modelação matemática para escoamento laminar no trecho com perfil de velocidade totalmente desenvolvido para dutos de seção quadrada ou retangular com qualquer geometria; combinar os modelos matemáticos para obtenção das trajetórias de partículas sedimentando no trecho de transição e no trecho com perfil totalmente desenvolvido que entram na região central e no topo do tubo de sedimentadores com ângulo de $60^{\circ}$ com o plano horizontal e verificar a existência de relações geométricas ótimas de seções transversais dos dutos em função das características do escoamento e de sedimentabilidade das partículas. Com base nos estudos realizados, conclui-se que:

1. Foi possível com os modelos adaptados, compatibilizar a trajetória da partícula no trecho de transição com sua trajetória no trecho com perfil de velocidade completamente desenvolvido;

2. Foi possível determinar, para os sedimentadores estudados, as velocidades máximas e mínimas de sedimentação da partícula; 
3. Independentemente do comprimento total do sedimentador, para baixas velocidades médias de escoamento, a sedimentação de fração considerável de partículas pode ocorrer no trecho de transição".

DOMBROSKI (1996) pesquisou a influência das condições de floculação na eficiência da flotação por ar dissolvido de alta taxa aplicada ao tratamento de água de abastecimento "com o objetivo de verificar a influência do tempo, gradiente de velocidade médio e número de compartimentos da unidade de floculação na eficiência de um reator estático de floculação e flotação por ar dissolvido e de uma unidade com escoamento contínuo de coagulação, floculação e flotação por ar dissolvido de alta taxa. Neste trabalho foi também investigada a potencialidade de estudos realizados no reator estático de flotação por ar dissolvido para determinar parâmetros de projeto que possam ser utilizados em unidades com escoamento contínuo. Foram realizados ensaios com dois tipos de água e utilizando reator estático de floculação-flotação por ar dissolvido e instalação com escoamento contínuo de coagulação-floculação-flotação por ar dissolvido de alta taxa. Dos resultados obtidos pôde-se concluir:

Água I utilizando reator estático de floculação-flotação por ar dissolvido:

- a otimização da dosagem de coagulante e pH de coagulação é necessária para que seja obtido bom desempenho da flotação;

- as condições ótimas de coagulação encontradas foram de dosagem de sulfato de alumínio de $40 \mathrm{mg} / \mathrm{l}$ e pH de coagulação na faixa de 6,2 a 6,5, tendo sido considerados aspectos como a eficiência de remoção, velocidade de flotação e consumo de coagulante;

- a fração de recirculação de $8 \%$ (em volume) com pressão na câmara de saturação de $41 \mathrm{kPa}$ forneceu os melhores resultados;

- o gradiente de velocidade médio de mistura rápida de $1000 \mathrm{~s}^{-1}$ com tempo de mistura rápida de $10 \mathrm{~s}$ apresentaram a maior eficiência de remoção de cor aparente;

- o aumento do gradiente de velocidade médio de floculação para menores tempos de floculação conduziu a melhores resultados;

- a determinação do tempo de floculação ótimo é fundamental para o bom desempenho da flotação; 
- os melhores resultados de remoção de cor aparente e turbidez foram obtidos para tempo de floculação de 20 min e gradiente de velocidade médio de floculação ótimo de $60 \mathrm{~s}^{-1}$, sendo bastante similar aos resultados obtidos para tempo de floculação de 24 min e gradiente de velocidade médio de floculação de $60 \mathrm{~s}^{-1}$;

- o escalonamento do gradiente de velocidade médio de floculação de 80-60 $\mathrm{s}^{-1}$ (um dos escalonamentos definidos pela metodologia proposta por PÁDUA², 1994) apresentou os melhores resultados em termos de remoção de cor aparente, tanto para tempo de floculação de 24 min quanto para tempo de floculação de $12 \mathrm{~min}$. Bons resultados foram obtidos utilizando-se combinações de gradiente de velocidade médio de floculação entre 60 e $100 \mathrm{~s}^{-1}$;

- os resultados obtidos, em termos de eficiência de remoção de cor aparente e turbidez, nos ensaios realizados no flotateste para tempo de floculação de $24 \mathrm{~min}$, anteciparam de maneira bastante razoável os resultados obtidos na instalação com escoamento contínuo;

- o flotateste serviu para otimizar parâmetros de projeto como tempo de floculação e número de compartimentos da unidade de floculação assim como, valores de gradiente de velocidade médio a serem utilizados na unidade de floculação de uma instalação com escoamento contínuo.

Água tipo I utilizando instalação com escoamento contínuo de coagulaçãofloculação-flotação por ar dissolvido de alta taxa.

- desde que as condições de coagulação e de floculação sejam adequadamente otimizadas, o desempenho da flotação foi relativamente equivalente tanto para taxa de aplicação superficial aparente na câmara de flotação de, aproximadamente, 360 $\mathrm{m}^{3} / \mathrm{m}^{2}$ dia quanto para $720 \mathrm{~m}^{3} / \mathrm{m}^{2}$ dia, para um determinado tempo de detenção na zona de contato;

- dentre os diversos valores estudados do gradiente de velocidade médio de floculação, as combinações com valores dentre 40 e $120 \mathrm{~s}^{-1}$, proporcionaram os melhores resultados;

\footnotetext{
2 PÁDUA, V. L. DE (1994). Metodologia para determinação dos gradientes de velocidade médios em
} unidades de floculação de mistura completa com câmaras em série e escoamento contínuo a partir de 
- o escalonamento do gradiente de velocidade médio de floculação teve pouca influência sobre o desempenho da flotação para o tempo de floculação de $24 \mathrm{~min}$, enquanto que, para 12 min de floculação tal parâmetro apresentou influência mais significativa;

- a unidade de floculação com dois compartimentos em série mostrou-se eficiente para promover a floculação precedendo a flotação;

- o tempo de contato adequado da zona de contato bolhas-flocos é de importância crucial para o bom desempenho da flotação;

- quando operada nas melhores condições de floculação, ou seja, tempo de floculação de 24 min, duas câmaras em série com gradiente médio de velocidade de $80 \mathrm{~s}^{-1}$ na primeira câmara e de $60 \mathrm{~s}^{-1}$ na segunda, a unidade com escoamento contínuo apresentou remoção de até $92,0 \%$ de cor aparente (cor aparente do efluente de $8 \mathrm{uC}$ ), 90,4\% de turbidez (turbidez do efluente de 0,55 uT) e 97,4\% de sólidos sedimentáveis totais (sólidos sedimentáveis totais do efluente de 0,8 mg/l). Com 12 min de floculação, gradiente médio de velocidade de $100 \mathrm{~s}^{-1}$ na primeira câmara e de 80 s-1 na segunda, a unidade apresentou remoção de até $86,0 \%$ de cor aparente (cor aparente do efluente de $15 \mathrm{uC}$ ), 86,7\% de turbidez ( turbidez do efluente de 0,8 uT) e 90,9\% de sólidos sedimentáveis totais (sólidos sedimentáveis totais do efluente de 3,0 mg/l). Em ambos os casos, tais resultados foram alcançados para velocidade de escoamento entre as placas na câmara de flotação de $31 \mathrm{~cm} / \mathrm{min}$ (taxa de aplicação superficial aparente(TASap) $\cong 360 \mathrm{~m}^{3} / \mathrm{m}^{2}$ dia).

Água tipo II utilizando reator estático de floculação-flotação por ar dissolvido:

- as condições otimizadas de coagulação nem sempre foram iguais quando obtidas em ensaios de coagulação-floculação-flotação e de coagulação-floculaçãosedimentação;

- ensaios de clarificação por flotação, os valores de dosagem de sulfato de alumínio de 30,50 e $70 \mathrm{mg} / \mathrm{l}$ com respectivos valores de $\mathrm{pH}$ de coagulação de 6,31; 6,45 e 6,28, apresentaram ótimos resultados de remoção de cor aparente e turbidez sendo relativamente similares entre si; 
- tendo em vista o consumo de sulfato de alumínio e remoção obtida de cor parente e de turbidez, pôde-se considerar como dosagem ótima para ensaios de clarificação por flotação a dosagem de $30 \mathrm{mg} / \mathrm{l}$ com pH de coagulação de aproximadamente 6,3;

- nos ensaios de clarificação por sedimentação, as condições ótimas de coagulação foram de $50 \mathrm{mg} / \mathrm{l}$ de dosagem de sulfato de alumínio para $\mathrm{pH}$ de coagulação de aproximadamente 6,4 .

Água tipo II utilizando instalação com escoamento contínuo de coagulaçãofloculação-flotação por ar dissolvido de alta taxa:

- considerando as condições empregadas nos ensaios realizados na instalação com escoamento contínuo utilizando-se a água tipo II, verificou-se para combinações do gradiente de velocidade médio de floculação entre 30 e $80 \mathrm{~s}^{-1}$, preferencialmente com valores de gradiente de velocidade médio de floculação da última câmara de floculação entre 30 e $40 \mathrm{~s}^{-1}$, para tempo de floculação de 24 min e três câmaras de floculação em série, mostraram-se adequadas para a clarificação por flotação da água estudada".

Estudos realizados por SANTOS (1997) "de uma unidade de flotação por ar dissolvido com escoamento vertical entre placas, aplicada à remoção de algas em águas de abastecimento teve os seguintes objetivos: construção, operação e avaliação do desempenho de uma instalação piloto de flotação de forma a se obter elevada concentração de algas em suspensão e construção e operação de uma unidade de flotação por ar dissolvido em escala de laboratório (flotateste) aplicada à água de estudo para determinação da dosagem ótima de coagulante (cloreto férrico); valor adequado do $\mathrm{pH}$ de coagulação; tempo e gradiente médio de velocidade adequados à floculação. Para este pesquisa utilizou-se de dois tipos de água bruta. Desde trabalho conclui-se que:

Água do tipo I:

- para água do tipo I, com elevada concentração de algas, observou-se que a eficiência de remoção de clorofila acima de $90 \%$ ocorreu em todas as dosagens de coagulante (cloreto férrico) investigadas $(5 ; 10 ; 15 ; 20 ; 22 ; 25$ e $30 \mathrm{mg} / \mathrm{l})$, desde que

Carlos, Universidade de São Paulo. 
coaguladas na faixa ótima de $\mathrm{pH}$ para valores de velocidade de flotação até 19,5 $\mathrm{cm} / \mathrm{min}$

- obteve-se eficiência de remoção de algas acima de 90\% com dosagem de $22 \mathrm{mg} / \mathrm{l}$ de cloreto férrico com $\mathrm{pH}$ em torno de 6,3 para velocidades de flotação de até $30 \mathrm{~cm} / \mathrm{min}$

- o gradiente de mistura rápida de $600 \mathrm{~s}^{-1}$ associado com o tempo de mistura de 30 $\mathrm{s}$ forneceu os melhores resultados de eficiência de remoção de algas;

- a quantidade de ar fornecida de $5 \%\left(4,39 \mathrm{~g} / \mathrm{m}^{3}\right)$ para velocidades até $19,5 \mathrm{~cm} / \mathrm{min}$ demostrou ser suficiente para obtenção de eficiência de remoção de algas acima de $90 \%$;

- os ensaios de floculação/flotação da água tipo I revelaram que, para valores de tempo e gradiente investigados, quanto maior o tempo de floculação menor o gradiente de velocidade de floculação necessário para obtenção da melhor remoção.

Água tipo II:

- a câmara de saturação utilizada, contendo recheio com 1,2 m de altura, composto de anéis de PVC, apresentou eficiência em torno de $83 \%$ da teórica, para valores de taxa de aplicação superficial de até $2052 \mathrm{~m}^{3} / \mathrm{m}^{2}$ dia;

- de maneira geral, a unidade de flotação de alta taxa estudada apresentou elevada eficiência de remoção de algas, sempre acima de 94\%, quando foi fornecida quantidade de ar na faixa de 3 a $5 \mathrm{~g} / \mathrm{m}^{3}$ de água bruta, mesmo quando submetida a taxas bastante elevadas (até $1070 \mathrm{~m}^{3} / \mathrm{m}^{2}$ dia) correspondente a velocidade entre placas de $100 \mathrm{~cm} / \mathrm{min}$;

- o melhor desempenho para remoção de algas foi obtido para taxa de aplicação superficial em torno de $214 \mathrm{~m}^{3} / \mathrm{m}^{2}$ dia, 98\%. Mesmo para taxa de aplicação superficial bem mais elevadas como $1070 \mathrm{~m}^{3} / \mathrm{m}^{2}$ dia obteve-se eficiência de remoção de $96 \%$;

- a aplicação de valores da concentração de ar dissolvido fornecida para a flotação acima da faixa ótima (3 a $5 \mathrm{~g} / \mathrm{m}^{3}$ ) acarretou piora no desempenho da unidade de flotação com módulo de alta taxa;

- a instalação do módulo contendo placas planas paralelas $\left(50^{\circ}\right.$ com a horizontal $)$ no interior da unidade de flotação não acarretou acúmulo nocivo de flocos flotados nos espaços entre as placas, ocorrendo um mecanismo de auto-limpeza". 


\subsubsection{Filtração}

REIS (1985) desenvolveu trabalho sobre a otimização de filtros de areia de fluxo descendente, com objetivo de explicitar os custos a serem considerados na fase de projeto de um sistema de tratamento de água no que diz respeito à filtração e propor uma metodologia de otimização. "Desenvolveu-se o modelo de filtração numa forma que permitiu efetuar uma resolução numérica deste para expressar explicitamente as suas previsões. Com base em oito variáveis de decisão independentes foi elaborado a função custo. Este trabalho demonstrou claramente a viabilidade da metodologia de otimização como ferramenta de projeto que considera as relações entre as diversas variáveis e parâmetros de um sistema de filtração".

Comparações entre a filtração ascendente e descendente de água decantada utilizando areia como meio filtrante foram realizadas por MATSUMOTO (1987). "O presente trabalho estudou e comparou o desempenho de dois filtros piloto de areia, sendo um de fluxo ascendente e outro descendente, quando é utilizada a água decantada como afluente. Com base no trabalho realizado, concluiu-se:

1. Para taxas de filtração entre 120 e $280 \mathrm{~m}^{3} / \mathrm{m}^{2}$ dia, a filtração descendente em areia (com grãos de tamanho compreendido entre 0,42 e 1,41 mm e camada de espessura igual a $70 \mathrm{~cm}$ ) produz água filtrada de qualidade superior à ascendente em areia (com grãos de tamanho entre 0,59 e 2,00 mm e camada com espessura variando de 70 a $130 \mathrm{~cm}$ ) tanto do ponto de vista físico como bacteriológico;

2. A filtração ascendente produz maiores volumes de água filtrada quando comparada à descendente, mesmo com camada de areia de espessura igual a $70 \mathrm{~cm}$;

3. Quanto maior a espessura da camada de areia, maior o volume de água produzido na filtração ascendente para uma mesma taxa de filtração;

4. Quanto maior a taxa de filtração, menor é o volume de água produzido na filtração ascendente para camada de areia de mesma espessura;

5. Qualquer que seja o sentido da filtração, ascendente ou descendente, a qualidade bacteriológica do efluente piora à medida que aumenta a turbidez, principalmente para valores superiores a aproximadamente 0,2 uT e se acentua à partir de $0,5 \mathrm{uT}$; 
6. A qualidade bacteriológica do efluente na filtração ascendente praticamente independe da taxa de filtração e espessura da camada de areia;

7. A evolução da perda de carga é mais acentuada na filtração descendente que na ascendente, pela má distribuição de impurezas ao longo do meio filtrante;

8. O aumento da produção de água filtrada não resultou proporcional ao aumento da espessura da camada de areia na filtração ascendente".

SOUZA (1990) estudou a influência do posicionamento do vertedor de saída nos sistemas de filtração com taxa declinante e taxa constante com nível variável. "Esse trabalho teve o objetivo de estudar o comportamento dos sistemas de filtração com taxa declinante e taxa constante com nível variável, quando a crista do vertedor de saída é rebaixada para níveis inferiores ao do topo da camada filtrante. Tal estudo proporcionou as seguintes conclusões:

1. O vertedor de saída posicionado no mesmo nível ou acima do topo da camada filtrante aumenta desnecessariamente a altura das caixas dos filtros;

2. É possível promover a operação de uma instalação piloto de um sistema de filtração com taxa declinante e avaliar, a partir das curvas de perda de carga resultantes da operação com o vertedor de saída posicionado no mesmo nível do topo do meio filtrante, o quanto este vertedor pode ser rebaixado;

3. As curvas de perdas de carga no meio filtrante são deslocadas paralelamente com a mudança do posicionamento do vertedor de saída, desde que a qualidade da água afluente não varie consideravelmente durante esta operação;

4. Desde que se garanta o nível mínimo de operação acima do topo do meio filtrante e, no caso dos sistemas de taxa declinante, se mantenha a entrada de água afluente continuamente afogada, o vertedor de saída poderá ser rebaixado, em relação ao topo do meio filtrante, até o mesmo valor da distância entre a curva de perda de carga resultante e a linha de pressões relativas negativas sem que haja possibilidade de ocorrência de pressões inferiores à atmosférica no interior do meio filtrante;

5. Nos sistemas de filtração com taxa constante e nível variável, o rebaixamento da crista do vertedor de saída é limitado apenas pelo nível mínimo de operação, pois 
as curvas de perdas de carga deslocam-se continuamente com a elevação do nível d'água, no sentido da não ocorrência de pressões inferiores à atmosférica;

6. A variação de perda de carga no filtro de taxa constante, com o tempo de operação, não resultou paralela à do sistema de taxa declinante no início dos ciclos de uma carreira, contrariando hipóteses assumidas em pesquisas anteriores que se basearam neste comportamento;

7. O rebaixamento da crista do vertedor de saída não alterou, significativamente, o comportamento dos sistemas de filtração estudados em termos de duração da carreira de filtração e da qualidade da água filtrada;

8. Em sistemas de filtração com taxa declinante, a granulometria do meio filtrante pode interferir no comportamento das taxas de filtração entre lavagens sucessivas. Quando a granulometria do meio filtrante for razoavelmente dispersa, durante um mesmo ciclo do funcionamento, os filtros que operam com taxas menores que a média tendem a diminuir as suas taxas com o tempo e os filtros que operam com taxas maiores, em conseqüência, tem as suas taxas crescentes com o tempo;

9. A escolha da carga hidráulica total disponível que promova uma configuração para as taxas de filtração, em uma bateria de taxa declinante, em que a relação entre a taxa máxima e média se situe entre 1,3 e 1,5, resultará em carreiras de filtração com durações satisfatórias".

GASTALDINI (1990) pesquisou a filtração rápida descendente com taxa constante em meios granulares não uniformes, fazendo modelação e análise econômica e operacional. "Os principais objetivos do tabalho são a modelação de um filtro rápido composto por múltiplas camadas de propriedades distintas e proposição de uma metodologia de otimização de filtros de dupla camada à luz da modelação desenvolvida. Formulou-se uma função objetivo computando-se custos de operação e de investimento anualizados, de uma unidade filtrante. Através da minimização do custo total anual foram determinadas as espessuras e os tamanhos médios dos grãos dos meios e a taxa de filtração, para várias condições de projeto de filtros rápidos de antracito e areia. A minimização do custo total possibilitou verificar que a vazão afluente ao filtro pouco interferiu nas espessuras e tamanhos médios dos grãos dos meios e na taxa de filtração. Estas variáveis sofreram maior influência das concentrações afluentes e efluentes ao filtro. A espessura da camada de antracito foi 
a variável que menos alterou para as diversas imposições de projeto, ficando sempre entre 5,5 e $11 \mathrm{~cm}$, na minimização dos custo total anual. A análise de sensibilidade identificou o custo da energia como o componente do custo total anual que mais interfere no mesmo. As carreiras de filtração apresentaram, normalmente, pequenas durações, mostrando a menor importância do custo dos produtos químicos. Concluiuse daí, que a estipulação de maiores valores para as mesmas resulta de necessidades operacionais e não econômicas. A imposição de carreiras de filtração mínimas de 12 e 24 horas proporcionou um grande acréscimo no custo total anual, principalmente evidenciado para concentrações de afluentes elevadas. A otimização operacional da filtração pode ser utilizada como critério para melhorar a eficiência de filtros já construídos. Este objetivo é conseguido pela minimização do custo operacional fixada a área filtrante, ou seja, a taxa de filtração".

Com o objetivo de estudar e comparar o desempenho de três filtros rápidos de areia com granulometria praticamente uniforme, variando-se os tamanhos efetivos, do maior e do menor grão para taxas de filtração compreendidas entre 200 e 750 $\mathrm{m}^{3} / \mathrm{m}^{2}$ dia, PREZOTTI (1990) desenvolveu um estudo sobre a influência da taxa de filtração no desempenho de filtros rápidos de areia praticamente uniforme. "O desenvolvimento do trabalho propiciou as seguintes conclusões:

1. A turbidez da água filtrada, após a etapa inicial de amadurecimento dos filtros, manteve-se sempre inferior a $1 \mathrm{uT}$ e com valores praticamente iguais em todos os filtros, para todos os ensaios realizados, independentemente da taxa de filtração e das características granulométricas do meio filtrante;

2. O filtro com maior granulometria (F3) e praticamente uniforme, apresentou os melhores resultados em termos de distribuição das impurezas retidas ao longo do meio filtrante, resultando carreiras de filtração mais longas para uma mesma taxa de filtração, e, por conseguinte, maior produção de água filtrada;

3. A espessura da camada filtrante de $1,20 \mathrm{~m}$ é um valor suficiente para filtros com características granulométricas próximas à do filtro F3, para taxas de filtração de até $700 \mathrm{~m}^{3} / \mathrm{m}^{2}$ dia;

4. O aumento da taxa de filtração acarretou uma maior distribuição das impurezas retidas ao longo do meio filtrante, para todos os filtros estudados; 
5. O efeito da estratificação do leito filtrante, com o posicionamento dos grãos mais finos no topo da camada, resultante da lavagem em contracorrente, é realmente minimizado, quando utilizam-se de meios filtrantes praticamente uniformes;

6. Na operação dos filtros com taxa constante, a queda livre do afluente e o nível da água variável no interior da caixa dos filtros, e a provável presença do amido de batata no afluente, podem ter contribuído de forma positiva para a obtenção de um melhor desempenho dos filtros".

TEIXEIRA (1991) realizou pesquisa com o intuito de propor um método para obtenção de parâmetros de projeto e operação de sistemas de filtração com taxa declinante. "Para o desenvolvimento deste trabalho foi montada uma instalação experimental trabalhando com taxa declinante variável, a qual apresentou um padrão de comportamento típico de tais sistemas, com as taxas de filtração mantendo-se aproximadamente constantes em cada ciclo, variando na forma de degraus e apresentado picos por ocasião da lavagem dos filtros; as lâminas d'água acima do meio filtrante variaram continuamente, caracterizando os diversos níveis de operação e a qualidade do efluente não mostrou qualquer tendência à ocorrência do transpasse final. Esse estudo permitiu concluir que:

1. Foram registradas pequenas, porém sistemáticas, variações das taxas de filtração durante cada ciclo de operação, com o aumento das taxas maiores e a redução das menores, podendo-se atribuir tais ocorrências à colmatação superficial do meio filtrante, em decorrência de uma penetração pouco profunda das partículas retidas no mesmo;

2. Eventuais perturbações na operação ocorridas durante determinado ciclo refletiam-se, a partir de uma certa magnitude, no comportamento dos ciclos subsequentes, com alterações nas taxas de filtração das diversas unidades; uma condição de normalidade era novamente atingida, em geral, após cada um dos filtros ter sido lavado;

3. A melhor condição de início de operação foi obtida quando os ciclos iniciais tiveram sua duração aproximadamente igual à dos ciclos com operação estável, com tal situação sendo atingida mais rapidamente; de qualquer modo, a estabilidade foi sempre atingida antes que cada um dos filtros fosse lavado pela terceira vez, após o início da operação do sistema; 
4. Os picos de vazão e nível de operação durante as lavagens foram bastante significativos, ocorrendo de maneira bastante rápida, o que pode ser associado à ausência de armazenamento de água à montante dos filtros da instalação piloto;

5. Sistema de filtração com taxa declinante (SFTD) e filtros trabalhando com taxa constante e nível variável, com meios filtrantes idênticos, apresentaram evoluções semelhantes das perdas de carga totais, quando o filtro independente era operado com uma taxa de filtração correspondente à da unidade do SFTD com o mesmo grau de colmatação; ou seja, a variação do nível d'água num filtro tendo a vazão fixada externamente é a mesma de uma unidade similar, cuja vazão resulta da operação com taxa declinante variável;

6. A variação do nível d'água $\left(\mathrm{N}_{2}-\mathrm{N}_{1}\right)$ durante cada um dos ciclos de um SFTD é equivalente ao de um único filtro que, recém lavado, seja operado com a mesma taxa de filtração registrada na unidade mais limpa daquele sistema; deste modo, a curva de variação do nível de operação num SFTD é paralela à de um filtro com taxa constante igual à taxa máxima daquele sistema, e não à taxa média;

7. Verificou-se a possibilidade da obtenção da duração dos ciclos de um SFTD, a partir da operação de um filtro piloto trabalhando com taxa constante, comprovando-se o método de levantamento de dados inicialmente proposto".

CUNHA Jr. (1992) realizou estudo comparativo de filtros rápidos de camada simples de areia e de camada dupla. "Este trabalho foi desenvolvido em três filtros rápidos de areia com granulometrias diferentes e praticamente uniformes e com um filtro rápido de camada dupla, areia e antracito, para taxas de filtração compreendidas entre 200 e $750 \mathrm{~m}^{3} / \mathrm{m}^{2}$ dia, utilizando-se de água decantada como afluente. Com base nos resultados do trabalho realizado, utilizando-se de água bruta pré-tratada com sulfato de alumínio e polímero de araruta seguido por floculação e decantação, pode-se concluir o seguinte:

1. Os filtros F1 e F2, cujos meios filtrantes são constituídos somente de areia com granulometria praticamente uniforme, são alternativas para substituir o F4, cujo meio filtrante é constituído de antracito e areia de granulometrias bastante conhecidas e utilizadas, inclusive com melhor desempenho; 
2. Para a água decantada que foi utilizada, o filtro F3, cuja granulometria do meio filtrante é maior que a dos demais filtros de camada única somente de areia, apresentou os melhores resultados, pela maior produção de água filtrada;

3. A distribuição das partículas retidas ao longo dos meios filtrantes homogêneos e praticamente uniformes dos filtros F2 e F3 é boa e melhor que a do filtro F1, sendo que as granulometrias de F2 e F3 são maiores que a de F1;

4. A utilização do meio filtrante com granulometria praticamente uniforme minimiza a estratificação causada pela retrolavagem e suas conseqüências;

5. Os quatro filtros estudados, nas condições em que foram apresentados $(1,2 \mathrm{~m}$ de espessura de leito filtrante nos filtros com meio filtrante somente de areia e 0,8 para o filtro cujo meio filtrante era composto de areia e antracito) e para taxas de filtração compreendidas entre 200 e $600 \mathrm{~m}^{3} / \mathrm{m}^{2}$ dia, após a etapa inicial da carreira de filtração mantém a turbidez inferior a 1 uT e praticamente igual".

Pesquisa desenvolvida por MOLINA (1996) comparou o desempenho do carvão antracitoso e do carvão betuminoso como materiais filtrantes em filtros de dupla camada e avaliou seu comportamento hidráulico e as características do efluente produzido. "Com base no trabalho, pode-se concluir que:

1. Os métodos usados nas determinações das propriedades granulométricas dos materiais filtrantes, tais como diâmetro volumétrico médio, porosidade e coeficiente de esfericidade, possuem grande confiabilidade, com base nos coeficientes elevados de ajuste que indicam grande correlação das características dos fenômenos mensurados com as equações que os modelam matematicamente;

2. O cálculo da perda de carga nos meios filtrantes limpos, apresentou resultados em ambos filtros com elevado grau de aproximação dos valores observados por um modelo proposto estudado;

3. Com base nos resultados obtidos utilizando modelo matemático, foi verificado que o coeficiente de esfericidade dos materiais filtrantes de carvão antracitoso e carvão betuminoso é um parâmetro de grande influência na eficiência de remoção de partículas nos meios filtrantes estudados;

4. A perda de carga no meio filtrante limpo constituído de carvão betuminoso e areia, resultou superior para todas as taxas de filtração estudadas, em relação ao meio filtrante limpo constituído por carvão antracitoso e areia. Baseado na teoria, a 
explicação a este fato é devido aos valores das propriedades diâmetro volumétrico médio, porosidade e coeficiente de esfericidade do carvão betuminoso, que forneceram maior área superficial para esta camada filtrante, em relação à área superficial da camada de carvão antracitoso.

5. Durante os ensaios de filtração foi possível comprovar que:

- todas as carreiras de filtração em ambos os filtros foram encerradas quando a perda de carga total ocorrida nos meios filtrantes atingiram o valor da carga hidráulica disponível da instalação piloto;

- durante a etapa intermediária das carreiras de filtração, ambos os filtros produziram água com qualidade satisfatória com relação a turbidez, a qual nas condições satisfatórias de pré-tratamento do afluente permaneceu sempre menor ao valor limite de $1 \mathrm{uT}$ estabelecido no Padrão Brasileiro de Potabilidade:

- com base nos resultados de eficiência média de remoção de sólidos suspensos totais, calculadas nas diferentes carreiras de filtração, não se observa diferença significativa na capacidade de remoção em ambos filtros, apesar de na maioria das carreiras o filtro constituído de carvão betuminoso e areia ter apresentado resultados ligeiramente melhores;

- para uma mesma taxa de filtração, a carreira no filtro de carvão betuminoso areia resultou na maioria dos ensaios, mais curta em relação a do filtro de carvão antracitoso - areia. A principal causa deste fato foi atribuída aos valores superiores da perda de carga inicial apresentados pelo filtro de carvão betuminoso - areia, resultando menor a fração da carga hidráulica disponível devida a retenção de impurezas neste filtro;

- a ação das partículas suspensas de penetrarem no interior dos meios filtrantes, observada em função da evolução das perdas de carga locais, é limitada às subcamadas superficiais em ambos os filtros, considerando-se uma profundidade de $10 \mathrm{~cm}$ nas carreiras com as taxas de filtração inferiores a 500 $\mathrm{m}^{3} / \mathrm{m}^{2}$ dia e de $30 \mathrm{~cm}$ para a carreira com a taxa de filtração de $600 \mathrm{~m}^{3} / \mathrm{m}^{2}$ dia".

WIECHETECK (1996) estudou a influência do método de lavagem nas características de carvões antracitoso e betuminoso utilizados em meio filtrante. "Esta pesquisa teve como meta verificar e comparar a alteração das características do 
carvão antracitoso e do carvão betuminoso, utilizados em meio filtrante, devido ao efeito abrasivo entre os grãos, decorrentes de lavagens exclusivamente com água e de lavagens independentes com ar e água. Do trabalho realizado, conclui-se que:

1. As metodologias utilizadas para as determinações do diâmetro volumétrico médio, porosidade e coeficiente de esfericidade apresentam resultados confiáveis, com base nos coeficientes de ajuste que indicam grande correlação das características dos parâmetros medidos com as equações que os modelam matematicamente;

2. O carvão betuminoso utilizado nos ensaios apresentou resultados satisfatórios quanto ao efeito abrasivo decorrente dos métodos de lavagem estudados, podendo ser utilizado como material filtrante alternativo;

3. A perda de material granular por abrasão não foi significativa, considerando que os ensaios foram realizados admitindo-se uma lavagem diária e um ano de uso de materiais;

4. As metodologias de lavagem empregadas, intermitentes contínuas produziram praticamente o mesmo efeito abrasivo entre os grãos, para ambos os casos (com e sem ar), de modo que o método de lavagem contínua pode ser empregado sem restrições, já que demanda menor tempo e fornece resultados semelhantes ao que se poderia esperar durante um ano nos filtros de uma estação de tratamento de água que empregasse meio filtrante contendo carvão betuminoso".

\subsubsection{Resíduos Gerados e Água de Lavagem}

CORDEIRO (1993) "estudou o problema dos lodos gerados nos decantadores em estações de tratamento de água, cujos objetivos básicos foram:

- efetuar levantamento entre as agências responsáveis pelo abastecimento de água e o controle de poluição, no Brasil, sobre o assunto.

- efetuar estudo de caso sobre possível impacto ambiental causado pelo lançamento de lodo dos decantadores em estação de tratamento de água tradicional ou convencional.

- efetuar estudos de caracterização dos lodos dos decantadores, levando-se em conta suas propriedades, visando o manuseio e disposição final. 
- analisar o comportamento dos lodos dos decantadores, quanto à remoção de água, sob a ação de pressões maiores, menores e iguais à pressão atmosférica visando a redução de volume dos mesmos.

- apresentar sugestões sobre metodologias de ensaios de laboratório, que permitam estudar o comportamento dos lodos gerados nos decantadores em estações de tratamento de água.

- iniciar discussão sobre planejamento dos sistemas de tratamento de água, visando não só a produção de água dentro do padrão de potabilidade, como também a minimização de geração de resíduos.

Com a realização desta pesquisa pode-se concluir que:

1. Até o momento, no Brasil, quase não existe conhecimento capaz de solucionar adequadamente o problema dos lodos de ETA;

2. A grande maioria das estações de tratamento de água convencionais consultadas lança seus lodos em cursos d'água próximos a elas. Em alguns casos no mesmo sistema que serve como manancial;

3. A grande maioria das agências responsáveis pelo abastecimento de águas a nível estadual e municipal não possui dados sobre as características dos lodos gerados nos decantadores das unidades por elas gerenciadas;

4. O lançamento de lodo de ETA em águas superficiais pode estar infringindo a Lei 6938 de 31 de agosto de 1981 em seu artigo 3 inciso II e III (alíneas c, d, e) e os agentes de saneamento enquadrados no artigo 3, inciso IV;

5. Algumas das agências consultadas já enfrentaram problemas de poluição, em decorrência do lançamento dos lodos de ETA no meio ambiente;

6. A grande maioria dos sistemas responsáveis de tratamento de água para abastecimento utiliza como coagulante primário o sulfato de alumínio;

7. A operação limpeza dos decantadores fere o artigo 22 da Resolução 20 de 18 de junho de 1986, do CONAMA;

8. A permanência dos lodos de ETA nos decantadores nas ETA convencionais por longos períodos é negativa e deve-se buscar alternativas no "lay-out" da ETA no sentido de evitar essa situação; 
9. O lodo da ETA estudada apresenta elevado DQO e alta concentração de sólidos (a DQO do lodo estudado apresentou valores acima de $5.000 \mathrm{mg} / \mathrm{l} \mathrm{e}$ a concentração de sólidos totais determinada chegou a $30.000 \mathrm{mg} / \mathrm{l})$;

10. A relação sólidos suspensos totais/sólidos totais no lodo da ETA estudada ficou em média em torno de $75 \%$;

11. A quantidade de sólidos sedimentáveis pode inviabilizar o lançamento dos lodos de ETA, mesmo em cursos d'água de porte médio (os valores para o lodo de ETA estudado chegou a $710 \mathrm{ml} / \mathrm{l})$;

12. No estudo de caso efetuado, o lançamento do lodo de ETA contrariou a Resolução 20 - CONAMA quanto aos seguintes parâmetros: sólidos sedimentáveis, ferro, cobre, chumbo, manganês, níquel. O lodo de ETA pode ser considerado como poluente;

13. A remoção de água dos lodos de ETA através de filtros-prensa pode não alcançar a eficiência desejada, fazendo com que a concentração de sólidos ainda seja baixa para manuseio (remoção máxima de água de 30\%);

14. A utilização de serragem como condicionador para filtro-prensa é econômica, eficiente e de baixo custo (com a serragem a remoção de água ultrapassou 80\%);

15. A torta resultante dos ensaios com serragem, após secagem em estufa, adquiriu resistência à compressão e merece ser estudada à parte para futuras utilizações;

16. O drenado do filtro-prensa tanto para lodos naturais quanto aqueles obtidos com serragem como condicionador, possuem características físico-químicas que possibilitam seu lançamento nas águas superficiais sem grandes problemas, dependendo da classe do corpo receptor ou até ser reutilizada, podendo voltar à entrada da ETA;

17. A eficiência apresentada por sistemas com pressões menores que a pressão atmosférica, foi bastante superior àqueles com pressões maiores que a pressão atmosférica;

18. O filtrado dos sistemas de filtro à vácuo apresentou características ligeiramente inferiores às de filtro-prensa, exceção feita à Manta 4390 - MT cuja eficiência foi baixa; 
19. Os ensaios com leito de secagem apresentaram excelentes resultados, tanto quanto ao aspecto de remoção de água por drenagem e por evaporação, quanto às características para disposição de água drenada;

20. A altura do lodo sobre o leito filtrante foi fator determinante para remoção de água por drenagem. No entanto, para a evaporação o período para "secagem" não foi muito variado para todos os ensaios (cerca de 10 dias);

21. O comportamento da manta de poliester como meio de suporte foi excelente, com possibilidade de substituir as camadas de pedregulho nos leitos convencionais;

22. O comprometimento do leito de areia (camada drenante), nos quatro casos ficou em torno de $100 \mathrm{~mm}$, podendo fazer com que a altura da camada drenante possa ser diminuída;

23. O resíduo sólido, resultante do leito de secagem poderá ser disposto em aterros sanitários;

24. Os ensaios de aeração, flotação e digestão anaeróbia não foram conclusivos quanto ao lodo da ETA estudado, talvez em função do tamanho das partículas e da presença de metais e de possíveis deficiências na metodologia empregada;

25. A adição de lodo de ETA para ensaios grosseiros de germinação de sementes de feijão (ensaios preliminares) mostrou-se bastante excelente, permitindo que o mesmo em solos adversos, as sementes obtivessem crescimento ativo (obs. - não foram realizados ensaios de lixiviação e análise foliar para verificar o caminhamento de metais);

26. O tamanho das partículas presentes nos lodos de ETA, e sua distribuição podem ser responsáveis pela dificuldade de remoção de água nos mesmos;

27. Adequações em ETA convencionais poderão reduzir a geração de lodos de ETA, possibilitando um melhor manuseio do material".

SCALIZE (1997) "realizou trabalho com água de lavagem de filtros da estação de tratamento de água de São Carlos/SP, a qual utiliza sulfato de alumínio como coagulante primário, com os seguintes objetivos:

a) caracterizar a água de lavagem dos filtros

b) estudar a eficiência da clarificação, por gravidade, com e sem o uso de polímeros sintéticos 
c) caracterizar o sobrenadante produzido e determinar algumas propriedades do lodo gerado

Os ensaios realizados permitiram concluir que:

- a sedimentabilidade do despejo foi superior quando utilizado polímero aniônico como condicionante em relação aos ensaios com polímero catiônico e não iônico, bem como sem polímero; isto permitiu obter sobrenadantes de melhor qualidade

- o melhor polímero para o condicionamento deste despejo foi o polímero de caráter aniônico F-30, e a melhor dosagem encontrada foi de $24 \mathrm{mg} / \mathrm{g}$ de SST seco. A relação dosagem de polímero por massa de sólidos seco (SST), permitiu obter ensaios com características semelhantes

- os sobrenadantes obtidos nos ensaios sem a utilização de condicionante apresentaram qualidade inferior aos condicionantes com polímeros. Estes sobrenadantes apresentaram características que permitiram a recirculação para o início da estação de tratamento de água, pois os valores de turbidez, SST e coliformes fecais obtidos nos sobrenadantes, mostram-se inferiores aos da água bruta. A recirculação juntamente à água decantada, antecedendo à filtração, poderá ser realizada desde que seja feito um monitoramento constante da qualidade final da água filtrada com o objetivo de verificar possíveis transpasses, visto que a qualidade da água decantada da ETA é melhor que a água a ser recirculada. Através da pesquisa do grupo coliformes no sobrenadante obtido concluiu-se que há necessidade de cuidados quanto a sua disposição, apesar do número destes organismos nos sobrenadantes não serem altos.

- em relação ao material sedimentado, através da análise microscópica pode-se observar que a quantidade de formas parasitárias presentes neste material foram superiores aos encontrados nos sobrenadantes. De modo geral, nos exames parasitológicos realizados no material sedimentado, obtido a partir de ensaios de coluna, foram encontrados cistos, ovos e larvas de parasitas patogênicos de interesse da saúde pública, os quais são causadores de parasitoses humanas, devendo-se portanto, tomar os devidos cuidados em sua manipulação, disposição ou reutilização. 
- quando comparados os tempos de filtração do lodo obtido sem e com polímero, pode ser observada uma grande diferença entre os resultados sendo que o condicionamento diminui consideravelmente este tempo para um mesmo volume tratado.

- nos ensaios para determinação da resistência específica do material sedimentado foram encontrados até 13,0 g/L de sólidos na torta, proveniente de lodo obtido através de ensaio com utilização de polímero aniônico e, SST de 14,33 g/L, chegando a ser mais de duas vezes superiores aos sólidos encontrados nos lodos sem a utilização de polímero. Quando não forem utilizados polímeros, os valores de resistência específica foram maiores indicando um lodo de difícil desidratação.

- através dos ensaios em Cone Imhoff para sólidos sedimentáveis concluiu-se que pode ser recuperado em torno de $99 \%$ da água para o despejo com valor de $\mathrm{SST}=58 \mathrm{mg} / \mathrm{L}$ com uma dosagem de $1,4 \mathrm{mg} / \mathrm{L}$, obtendo sobrenadante com turbidez da ordem de 9 uT, o que é superior ao ensaio sem utilização de polímero.

- o lodo obtido apresentou grande quantidade de metais, sendo ferro o metal encontrado em maior concentração, na ordem de 1,0 a $1,5 \mathrm{~g} / \mathrm{L}$, em contrapartida o cromo foi encontrado em menor quantidade, entre 0,30 e 0,54 $\mathrm{mg} / \mathrm{L} "$.

\subsection{A Evolução do Pensamento Gerencial}

Na década de 70 já se discutia a questão do gerenciamento no campo do saneamento; um simpósio promovido pela ABES em Belo Horizonte, em 1977, enfatiza esse assunto. Várias empresas de saneamento como a COPASA, SABESP e a SANEPAR, desenvolveram experiências de gerenciamento dentro do serviço de abastecimento de água e coleta de esgoto. Estas experiências mostraram que implantar um programa de gerenciamento não é algo tão simples como alguns pensam, pois requer participação de todos os membros do serviço. 
De acordo com TANAKA et al. (1971) a Companhia de Saneamento da Baixada Santista constituída em 1970 percebeu a necessidade do serviço funcionar em bases empresariais, com unidades de controle e planejamento. Percebe-se já nesta época a falta de um melhor relacionamento com o público consumidor no qual possa conhecer e interpretar os anseios, necessidades e reações dos públicos em relação aos serviços da empresa. Esta observação fez com que a empresa trabalhasse esse aspecto, pois isto é indispensável para atingir os objetivos da empresa com sucesso. Desenvolver o nível de instrução do funcionário foi outra meta da empresa, pois com essa ação pôde perceber em todos os setores uma afinidade com os objetivos desejados pela mesma. O estabelecimento de uma política salarial torna o caminho para o sucesso mais fácil à medida que o funcionário sinta-se recompensado pelo trabalho que presta, ou seja, tem salário razoável e este salário poderá progredir à medida que se esforce e se dedique mais ao trabalho.

Segundo PRETO \& BÁGGIO (1994) para desenvolver o planejamento operacional são fundamentais as metas operacionais e planos de ação. A SANEPAR fez várias tentativas de implantação de um processo de planejamento no qual algumas ações ocorreram no sentido de resgatar a filosofia da "administração por resultados" ao invés de "administração apaga incêndio". O trabalho que foi desenvolvido de 1983-1990 pode concluir que a introdução de planejamento operacional possibilitou melhorias sensíveis no padrão de desempenho de Superintendência, fazendo com que a mesma cumpra com o objetivo de bem-servir à comunidade propiciando-lhe melhorias na qualidade de vida.

FUKS (1987) destacou a importância do gerente como fator de sucesso nas empresas de saneamento básico, sendo citada a importância da atuação gerencial para melhorar a eficiência da empresa. O mesmo afirma a importância do trabalho de equipe, da motivação e mobilização para alcançar os objetivos almejados. A SABESP desenvolveu um modelo de atuação para os gerentes onde mostra que planejamento, organização e controle são ferramentas e não a função do gerente. A função do gerente é de manter a estrutura operando, preparando e criando condições para que as pessoas possam usar o seu potencial. Para gerenciamento eficiente é necessário o desenvolvimento das pessoas envolvidas no trabalho, o que se dá continuamente dia após dia, de forma a propiciar melhoras na execução de sua 
função e em sua vida, criando um ambiente de trabalho harmonioso onde a equipe se torne altamente produtiva. Para obter sucesso na organização o gerente deve definir claramente os objetivos, a política de trabalho, as diretrizes, o mesmo deve conhecer as necessidades humanas, promover estímulos, seminários anuais para implantar e discutir a filosofia e estabelecer programas de desenvolvimento e reuniões mensais para avaliar o processo e divulgar as informações a todas a pessoas do grupo.

A Figura 6 esquematiza a visão da maioria dos gerentes dos serviços de abastecimento de água, observada pela linha preta. A linha vermelha representa a visão que os gerentes devem possuir.

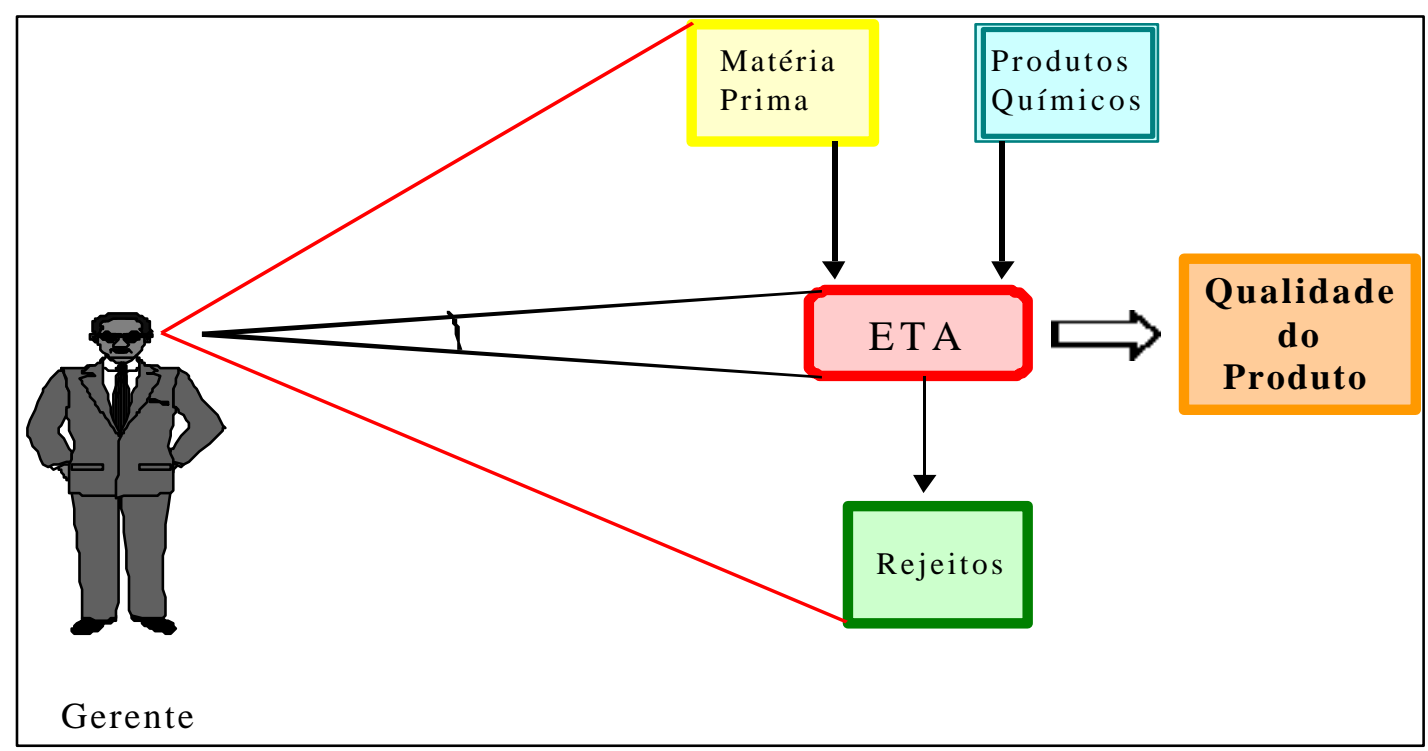

Figura 6: Visão sistêmica necessária para o serviço de água para abastecimento

A Figura 7 representa esquematicamente os fatores que influem nas estações de tratamento de água, com suas entradas (matéria prima, insumos e recursos humanos) e saídas (produto final e rejeitos). Pode-se observar uma situação hipotética e suas prováveis implicações no sistema: ao adquirir matéria prima de baixa qualidade, a quantidade de insumos introduzidos no tratamento tenderão a aumentar, pois a meta do tratamento é produzir água atendendo o padrão de potabilidade. Para que o resultado seja satisfatório o operador, bem como seu superior deverão ter amplo domínio da dosagem de produtos químicos que empregarão no tratamento e como deverão proceder quando a matéria-prima apresentar características diferentes das usuais. Se existe aumento de produtos 
químicos na purificação da água, automaticamente haverá maior formação de rejeitos. A qualidade da água deverá ser mantida, porém algumas vezes devido a falta de preparo do operador ou mesmo da qualidade do produto químico empregado no tratamento esta pode sair insatisfatória.

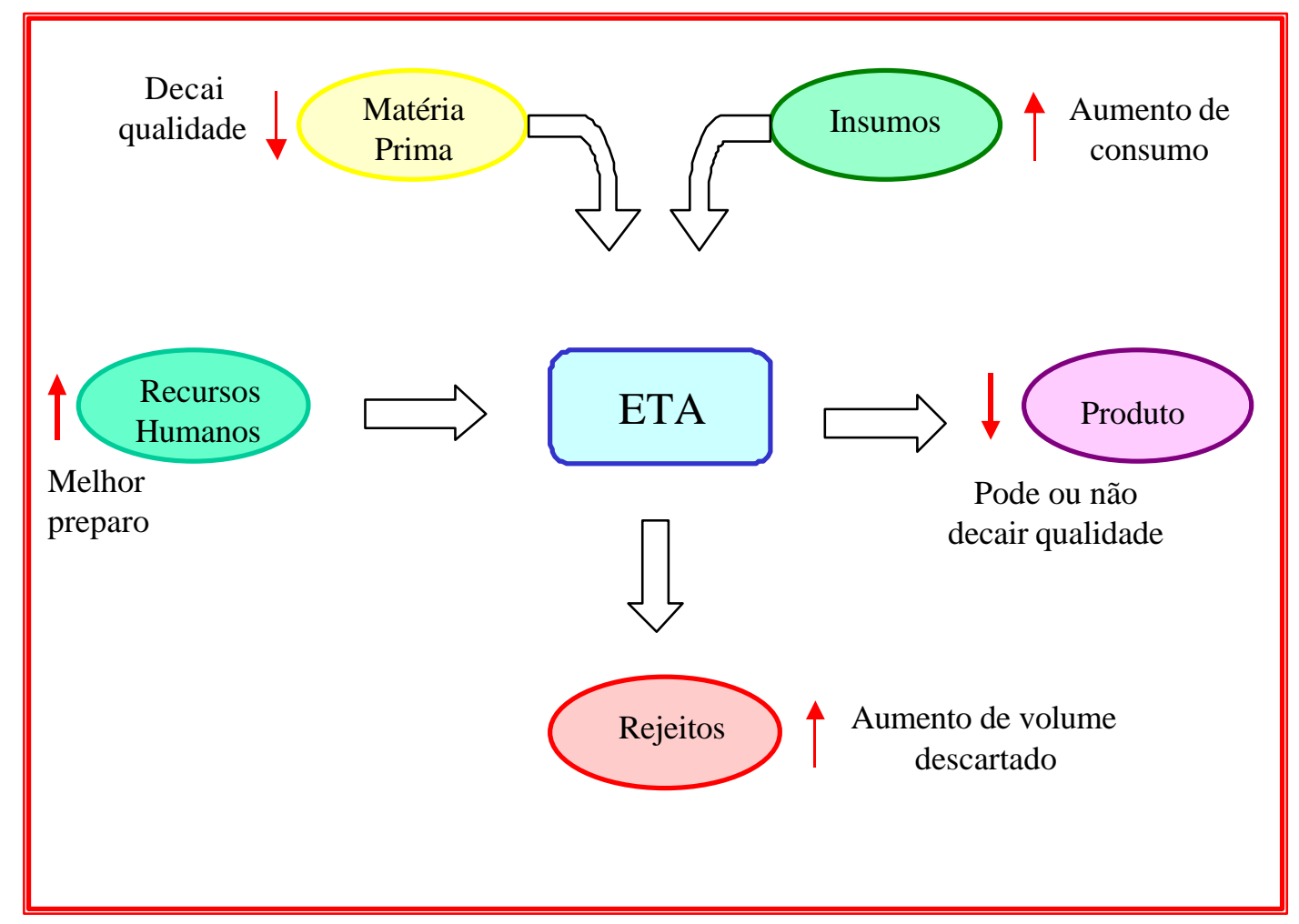

Figura 7: Esquema do processo de potabilização da água

\subsection{Qualidade do Serviço e do Produto}

"Qualidade é uma doutrina recente, inventada em 1934 durante o crescimento do tailorismo industrial. Somente em 1980 que muitas companhias de distribuição de água iniciaram a interessar pela qualidade do serviço e começaram adaptar soluções que eram empregadas nas indústrias" (SIMON,1996).

Nesse mesmo trabalho, o autor define qualidade de serviço como a "diferença entre as expectativas do cliente com respeito ao produto e a percepção da qualidade depois do uso do mesmo. Todavia este conceito não é facilmente aplicado para 
companhias de distribuição de água que simultaneamente oferecem um produto e um serviço, porque a qualidade do produto está indissociavelmente relacionada à qualidade do serviço. Antes de tudo, a melhoria da qualidade do serviço requer profunda mudança do estilo da empresa. Esta mudança de ênfase levou a Lyonnaise des Eaux a aumentar a consciência dos funcionários sobre este tema, assim como a educá-los. Esta mudança incitou as companhias de distribuição de água a intensificar seus esforços no contato com o cliente.

A melhoria da qualidade do produto tem sido uma prioridade das companhias de distribuição de água que enfrentam sérias pressões:

- maior responsabilidade a respeito da questão sanitária;

- aumento severo do padrão de qualidade;

- expectativas mais elevadas sobre a parte dos consumidores que identificarão mais importância no futuro sobre as qualidades organolépticas da água da torneira (sabor e odor, aparência, etc.).

Para conseguir melhorar a qualidade do serviço é essencial trabalhar o lado humano. Empresas como Lyonnaise des Eaux, dedicam mais de 5\% de sua folha de pagamento para continuação da educação de seus funcionários. O projeto desta companhia têm progredido por vários estágios, dando aos empregados não somente a oportunidade de expressar opiniões, mas também tomar iniciativas sólidas.

O custo da qualidade do serviço pode ser percebido em vários caminhos:

1- O custo da qualidade é muito alto porque: adiciona-se os esforços requeridos para melhoria da qualidade do produto; significa profunda modificação do estilo da casa.

2- O custo da qualidade do serviço pode também ser considerado ridiculamente baixo porque:

- os esforços ligados a qualidade podem contribuir para melhoria da operação da companhia ao mesmo tempo que aumenta a satisfação do cliente;

- oferece oportunidade de melhoramento da imagem da companhia, lealdade municipal, satisfação dos fornecedores de produtos;

- isto é necessário desde que a qualidade da água seja por causa do cliente”.

Segundo HOESKSTRA \& VAN der ZWAN (1996), a Dutch Watercorks Association iniciou em 1992 um programa para introduzir o Gerenciamento da Qualidade Total (GQT) para a indústria de abastecimento de água. Foram 
selecionadas duas companhias como pilotos: Dune Water Company of South Holland e Tilburg Water Suplly Company. A iniciativa teve muito sucesso. Em ambas as companhias o sistema de gerenciamento da qualidade, feito sob medida para suas respectivas necessidades, está em operação e um manual para Sistemas de Gerenciamento da Qualidade para a indústria foi desenvolvido. $O$ autor define Gerenciamento da Qualidade Total como "gerenciamento em organização tal que todos os membros da cooperativa melhorem:

- a qualidade de seus produtos e serviços;

- a qualidade de suas atividades;

- a qualidade de sua meta para obter a satisfação do cliente, rentabilidade organizacional a longo prazo, e os benefícios de seus membros, levando em conta as necessidades da sociedade.

Com os três anos de operação do GQT essa companhia apresentou algumas experiências:

- o local (posição hierárquica) inicial para definir o sistema de gerenciamento é influenciado pelo tamanho e complexidade da organização. Um enfoque de cima para baixo numa empresa pode por em risco o sucesso pela visão limitada que o gerente senior tem da realidade e da prática daquilo que é feito pelo funcionário que realiza o trabalho. Por outro lado os operadores não tem conhecimento das considerações políticas da empresa. A companhia utilizou um enfoque a partir de uma posição intermediária para possibilitar o acesso fácil tanto às pessoas que tomam decisões e fazem as políticas da empresa quanto aos operários.

- uma vez que o processo do GQT é iniciado, muitos empregados o vêem como uma motivação para realizar suas tarefas com maior responsabilidades.

- é fundamental a criação de manuais para as tarefas desenvolvidas pela empresa.

- a realização de auditorias anuais nos departamentos da empresa, realizadas pelo gerente de qualidade, é muito importante.

- deve haver uma preocupação maior com os ensinamentos de tarefas básicas de modo a evitar que os empregados realizassem atividades simples de suas próprias maneiras, e não da maneira correta.

- os novos projetos não devem ser desenvolvidos rapidamente sem a sua devida atenção, pois os riscos envolvidos são muito grandes. Um sistema de gerenciamento 
desenvolvido cuidadosamente requer pelo menos um ano de estudo com a participação de muitas pessoas com várias especialidades.

- uma maior atenção deve ser dada às "estruturas de comunicação". A experiência dessa empresa mostra que $70 \%$ dos problemas encontrados podem ser atribuídos a carência da comunicação efetiva.

- a Norma ISO 9001 é vista como ponto de partida, porém ela não será totalmente adequada a todos os tipos de empresas, especialmente autarquias que não visam lucro".

De acordo com SMITH et al. (1995) a Inglaterra e o Japão estão desenvolvendo juntos programas de gerenciamento para água de abastecimento através de trocas de informações e tecnologias. Estes países acreditam que a verdadeira lição do século 21 é que a água será considerada como um bem valioso antes de ser perdida. É importante lembrar que a água está disponível nos rios mas o serviço de coleta, tratamento, distribuição tem custo elevado. Portanto, dinheiro e tecnologia terão que caminhar juntos para servir o cliente com eficiente abastecimento e serviço desejável. "Os principais princípios das organizações de água da Inglaterra e dos Países de Gales são:

- gerenciamento da qualidade da água através de usos identificados e controle da quantidade de descartes para não causar prejuízos aos corpos receptores;

- adoção de visão holística na companhia de tratamento de água;

- desenvolvimento de programas de treinamento para todo quadro e em particular para os operadores;

- investimento em materiais para realizar a remoção de nitrato e pesticidas".

O índice de perdas (físicas ou não físicas) de água estimado pela maioria dos especialistas da área encontra-se na maioria das cidades brasileiras por volta de $40 \%$. As perdas físicas são aquelas em que há vazamentos através de ruptura de tubulação, vazamento em juntas, entre outros. Pode-se definir perdas não físicas como sendo aquelas provenientes de ligações clandestinas, erros de medição, deficiência no cadastro de consumidores, hidrômetros problemáticos, consumos públicos não medidos. Estima-se que a ETA seja responsável por aproximadamente 5\% dessa perda; este dado dificilmente é medido pela empresa. Toda essa água produzida e não consumida acarreta prejuízo à empresa e a população servida, existindo lugares 
onde são necessários a realização de rodízios, o que poderia ser sanado com a diminuição das perdas. A redução e o controle desse índice pode gerar benefícios tais como execução de novas obras, equipar e modernizar o serviço, abastecer novos loteamentos, melhorar o nível dos trabalhadores da empresa.

A racionalidade gerencial em um serviço de abastecimento de água pode ser assegurada através da observação de alguns requisitos:

a) o sistema de abastecimento de água deverá ser capaz de atender à demanda dos consumidores (Quantidade);

b) a água fornecida deverá satisfazer ao padrão de potabilidade (Qualidade);

c) o abastecimento deverá ser contínuo, sem intermitência (Regularidade);

d) o sistema de abastecimento deverá estar sob controle, entendendo-se essa condição como o conhecimento e o domínio, pelo pessoal de operação e manutenção, de todas as variáveis que caracterizam o funcionamento do sistema (Confiabilidade);

e) o custo total capitalizado ao longo do período de projeto (construção, operação, manutenção, administração) deverá ser o menor possível (Custo).

A realização plena desses princípios de adequação requer o controle de todos os fatores determinantes do funcionamento do sistema.

Considerando o caráter de efeito das perdas, qualquer processo destinado a combatê-las e reduzi-las deve configurar um conjunto harmônico de ações objetivando romper as causas que determinam o aparecimento e permanência das mesmas. Dessa forma, deve ficar bem caracterizado que o processo de redução e controle de perdas, tal como aqui conceituado é um processo que, a par de medidas de intervenção imediata destinadas a obter resultados positivos factíveis a curto prazo, deve prever um conjunto suplementar de ações voltadas à eliminação ou atenuação das causas de ocorrência de perdas. Além disso, é preciso considerar que, pelo fato de tais causas apresentarem uma distribuição ampla por todas etapas, fises e componentes da gestão técnica e administrativa dos sistemas, essas ações representam uma verdadeira revolução no modo de ser e estar dos serviços de abastecimento de água e das companhias concessionárias desses serviços; as mudanças a serem operadas envolvem desde as fases de planejamento e projeto, passando pela construção, aquisição e gerenciamento de materiais e equipamentos, operação, manutenção, organização e administração. 
Nota-se, portanto, que o combate e o controle de perdas envolve agentes e sistemas institucionais internos e externos às companhias, o que leva à necessidade de uma ação conjunta e solidária de empresas, objetivando alterar a dinâmica dos fatores e relações que determinam o estado atual dos sistemas de abastecimento de água no Brasil. Isso implica que os Programas de Controle de Perdas das empresas não devem ser implementados isoladamente, posto que, além das ações eminentemente domésticas, as empresas de saneamento necessitarão induzir mudanças em agentes externos, tais como projetistas, empreiteiros e fornecedores de materiais e equipamentos, tarefa esta exequível racionalmente apenas através da ação conjunta das empresas.

As perdas físicas podem causar prejuízos à qualidade da água se a rede de distribuição por alguma falha do sistema não estiver operando sob pressão, podendo desta forma permitir que material nocivo entre na tubulação através das perfurações.

Conforme artigo mencionado na revista Saneamento e Municípios (Dez 96/Jan 97) o controle da qualidade da água é realizado pelo Ministério da Saúde, porém os insumos empregados no tratamento não. São freqüentes empresas fornecedoras de produtos químicos usados no tratamento de água aplicarem fraudes como vender cal de construção civil, sulfato de alumínio contaminado com metais pesados, entre outros. Esses acontecimentos geram sérios prejuízos tanto à qualidade da água quanto à operação da estação de tratamento. Por isso um grupo de técnicos da área de produção de água de serviços municipais e companhias estaduais de saneamento, estão lutando para que o Ministério da Saúde passe a enquadrar os insumos para tratamento de água na categoria "alimento" e passe a expedir certificação para os produtos à venda no mercado, enquadrando-os na categoria que regulamenta os gêneros alimentícios. Nesse mesmo artigo é apresentado um modelo de edital de licitação contendo orientações básicas para aquisição de produtos químicos.

Atualmente, caso a água fornecida pela empresa de abastecimento não atenda a qualidade requerida, o consumidor pode acionar o Código de Defesa e procurar o Procon. Este tipo de ação ainda é inédito, mas inicia-se uma fase de cidadania e as empresas deverão ficar atentas, pois a utilização de produtos químicos fora de especificações no tratamento da água poderá prejudicar o produto final de forma que 
este não apresente resultado satisfatório. A empresa que não produzir água conforme o padrão de potabilidade estará correndo risco de ser processada e ter sua concessão cassada.

Nos últimos anos cresceu o número de pessoas que mesmo recebendo água tratada em sua residência não a utiliza para dessedentação, preferindo comprar água mineral. Um dos motivos aparentes do consumo da água mineral é a falta de confiança na qualidade da água fornecida pela empresa de abastecimento. Contudo nem sempre a água mineral adquirida encontra-se com qualidade satisfatória, pois existem muitas fontes de água que apresentam-se em estágio de contaminação e não passam por nenhum processo de tratamento, enquanto que a fornecida pela empresa é tratada e potável. Uma garantia da manutenção da qualidade da água fornecida pelo serviço de água é o cidadão ter o cuidado de limpar seu reservatório pelo menos 2 vezes por ano ou o fornecimento contínuo de água pelo serviço de forma a eliminar os reservatórios.

Para a empresa prestadora de serviços poder atender a população com água de qualidade e em quantidade é importante que sejam implantadas ações simples como elaborar o "lay-out" da estação de tratamento de água localizando e caracterizando todo o processo. Sabendo quantas bombas existem, quais suas funções e suas características, torna mais fácil a manutenção, a avaliação do rendimento da bomba e quando deverá ocorrer a troca, por exemplo. A obtenção de tais informações não despenderiam muito tempo, devendo em seguida serem armazenadas em computador visto que atualmente é um meio barato e fácil de manutenção e construção de banco de dados, possibilitando fácil acesso a informação e a solução de eventuais problemas.

O nível salarial dos operadores de ETA é baixo, provocando pouco interesse pela função e atraindo cada vez mais pessoas pouco qualificadas. Essa realidade traz consigo a necessidade de treinamentos contínuos, para que o funcionário possa desempenhar seu papel com responsabilidade e segurança.

A oportunidade de participar de cursos sejam eles técnicos, de segurança, anti-drogas, entre outros, propiciam crescimento pessoal dos funcionários evitando acidentes ou erros no trabalho bem como em sua vida pessoal. 


\subsection{Gerenciamento da Produção}

"A função produção é importante para a organização porque afeta diretamente o nível pelo qual ela satisfaz a seus clientes" (SLACK et al., 1997). No caso das ETA essa função é mais ampla em virtude do monopólio. A produção pode ser modelada pelo sistema de "entrada-transformação-saída" (como pode ser visto na Figura 8), onde "entrada" pode ser classificado como recursos de transformação que agem no sentido dos recursos transformados, que de algum modo são transformados pela produção. O "saída" é composto de bens ou serviços.

$\mathrm{Na}$ Figura 8 pode ser visualizado um modelo geral de administração da produção e da estratégia de produção, supondo uma nova operação sendo implantada. Primeiro, essa operação seria projetada e só na fase de operação, as atividades de planejamento e controle devem ser continuamente melhoradas.

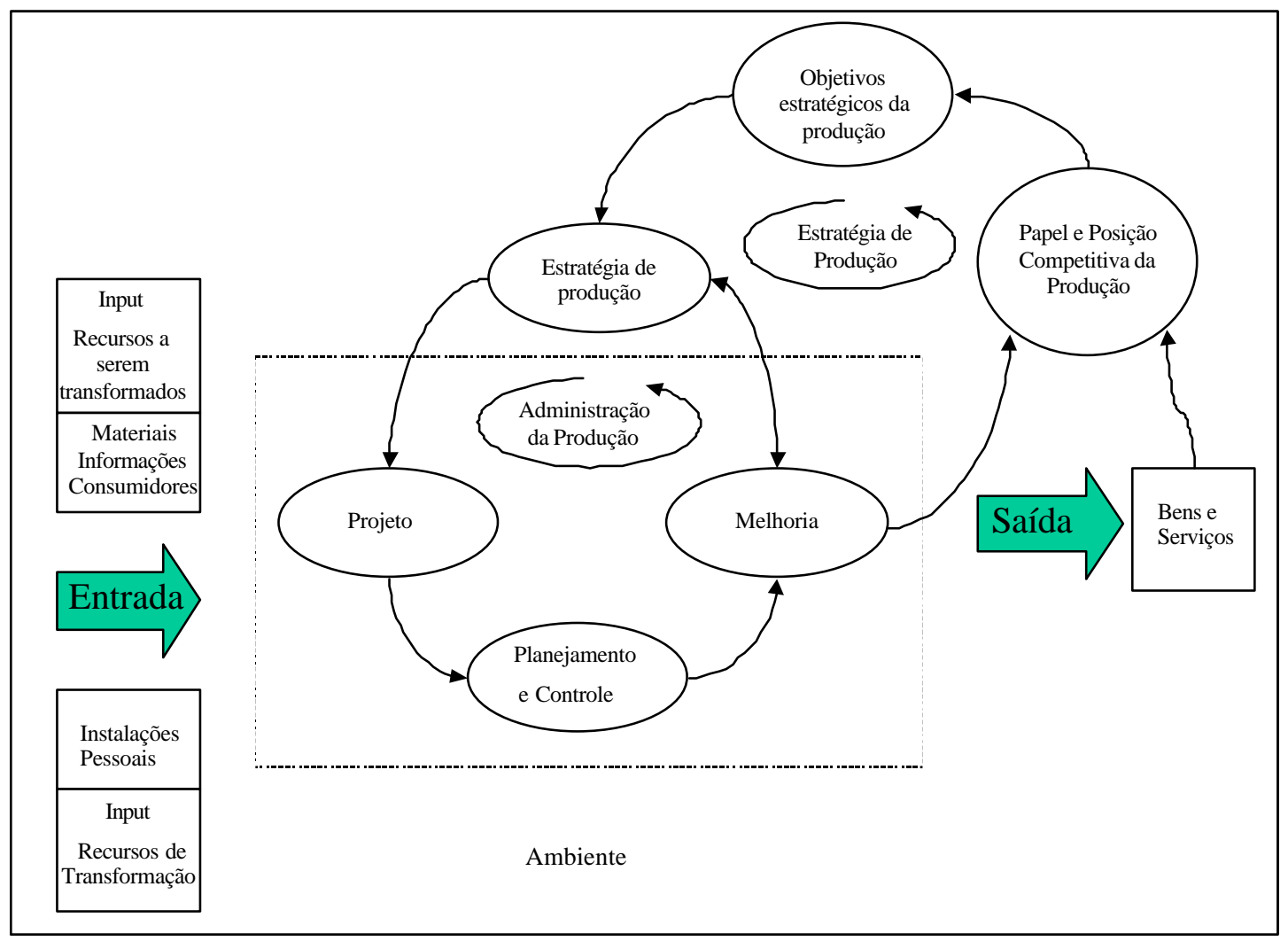

Figura 8: Modelo geral de administração da produção e estratégia de produção

Fonte: SLACK, N. et al.(1997) 
A reação aos bens e serviços produzidos determinará se a produção está sendo bem administrada. Se o 'output' estiver satisfazendo os consumidores, o papel da função produção em contribuir para os objetivos competitivos ou estratégicos será confirmado. Caso contrário, os objetivos da função produção precisarão ser revistos. Esses objetivos são aperfeiçoados e 'operacionalizados' na estratégia de produção da organização. Nesse sentido, 'operacionalizados' significa que os objetivos estratégicos da organização e suas atividades de produção são coerentes. Isso é mostrado com uma conexão entre a estratégia de produção e, principalmente, a atividade de projeto, mas na realidade, a estratégia de produção influenciará também as atividades de planejamento e controle e de melhoria.

Sem dúvida, à medida que a atividade de melhoria, gradualmente, enriquece o desempenho da produção, ela pode afetar a estratégia de produção ao proporcionar novas oportunidades para a produção contribuir para a competitividade. A atividade de melhoria também modifica o papel da produção na organização, movendo-a em direção a um papel central no futuro da organização.

O projeto do trabalho é responsável pela decisão de qual tarefa alocar para cada pessoa da organização e em qual seqüência desempenhá-la, onde desenvolver o trabalho, como as pessoas deveriam interagir com seu local de trabalho, quem mais poderia auxiliá-lo, quanta autonomia será dada e quais habilidades deverão ser desenvolvidas no pessoal. As decisões na definição do trabalho devem ser claras e com altos interesses, segurança e proporcionar uma qualidade de vida de trabalho razoável".

Conforme SLACK, et al. (1997), "o gerenciamento de projeto de sucesso depende de o projeto ter meta claramente definidas, gerenciamento de projeto competente, apoio da administração superior, membros de grupos competentes, recursos suficientes disponíveis, adequados canais de comunicação, habilidade de incentivar retroalimentação, resposta às necessidades dos clientes, mecanismos de solução de problemas e continuidade entre o pessoal de projeto. $\mathrm{O}$ gerenciamento de projeto apresenta cinco estágios:

Estágio 1 - Compreensão do ambiente do projeto;

Estágio 2 - Definição do projeto;

Estágio 3 - Planejamento do projeto; 
Estágio 4 - Execução técnica;

Estágio 5 - Controle do projeto.

O ambiente de projeto corresponde a todos os fatores que podem afetá-lo durante a sua vida. Seu entendimento permite direcionar como este será executado e determinar as incertezas que a ele serão inerentes.

O segundo estágio estabelece meta e objetivos claros do trabalho a ser desenvolvido. O gerenciamento do projeto apresenta três objetivos: custo, tempo e qualidade. Uma tarefa chave do gerente é controlar os recursos de modo que os custos planejados não sejam excedidos. Apesar de as atividades poderem ser diminuídas, o tempo para completar o plano somente pode ser mudado através de uma redefinição de seus objetivos. O resultado do trabalho proposto deve adequar-se às suas intenções, isto é, deve funcionar conforme o esperado, apresentando qualidade em relação à sua conformidade do produto final com as suas especificações originais e a adequação das especificações em si.

Com o planejamento do projeto tem-se o levantamento do custo e da duração do plano, determinando o nível de recursos que será necessário. Um bom planejamento auxilia na alocação e monitoramento do trabalho, bem como avalia o impacto de qualquer mudança que ocorra sobre o mesmo.

No controle da obra proposta é realizado monitoramento para verificar como a mesma está progredindo, avaliar seu desempenho e comparar as observações monitoradas com as projetadas.

Antes que o desempenho seja modificado é necessário que o mesmo seja medido. Isso pode ser feito com os objetivos de desempenho: qualidade, velocidade, confiabilidade, flexibilidade e custo.

A representação esquemática do gerenciamento de projeto pode ser vista na Figura 9. 


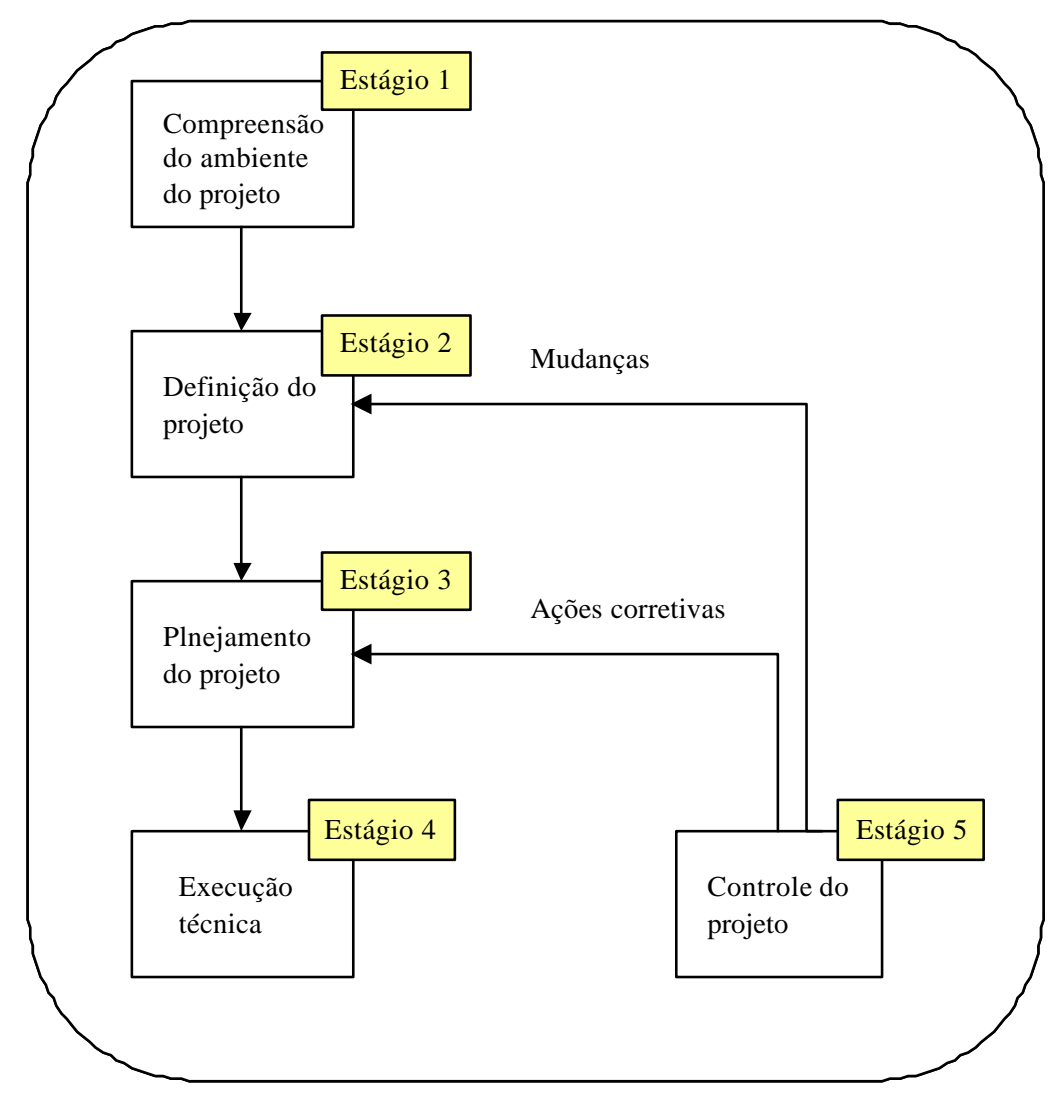

Figura 9: Modelo de Gerenciamento de projeto

Fonte: SLACK, N. et al.(1997)

\subsection{Gerenciamento da Qualidade}

Segundo BROCKA \& BROCKA (1994), gerenciamento de qualidade é definido como "melhorias sistemáticas e contínuas na qualidade do produto, serviços e na vida das pessoas, utilizando todos os recursos financeiros e humanos disponíveis". A melhoria é direcionada para satisfazer objetivos amplos, tais como: custo, qualidade, visão de mercado, planejamento e crescimento da empresa.

O gerente necessita ter visão sistêmica para a obtenção de realizações com sucesso. Sem este raciocínio o gerente provavelmente encontrará dificuldades em atingir seus objetivos. 
A divisão dos problemas parece facilitar tarefas e questões mais complexas, entretanto isso impede de enxergarmos as conseqüências de nossos atos e perde-se a noção de integração com o todo.

Segundo SENGE (1990) cinco novos componentes vêm convergindo para inovar as organizações; são eles: raciocínio sistêmico, domínio pessoal, modelos mentais, objetivo comum, aprendizado em grupo.

\section{i. Raciocínio sistêmico}

Para melhor entender a importância da visão sistêmica, veja o exemplo: "As nuvens se acumulam, o céu escurece, as folhas viram para o alto e sabe-se que vai chover. Também tem-se informação que, depois da chuva, a enxurrada penetrará nos lençóis de água subterrâneos a quilômetros de distância, e no dia seguinte o céu estará limpo.

Todos esses eventos são distantes no tempo e no espaço, no entanto estão todos interligados em um mesmo esquema. Cada um deles influencia todos os outros, influência esta que geralmente não encontra-se ao alcance da vista. Só se pode entender o sistema das chuvas observando-se o conjunto, não apenas uma das partes" (SENGE,1990). Nos serviços realizados pelo homem existem inter-relações entre as ações, portanto não pode se concentrar em partes isoladas do sistema.

\section{ii. Domínio pessoal}

O nosso objetivo pessoal pode ser melhor esclarecido e aprofundado quando há o aprendizado do domínio pessoal, assim como o desenvolvimento da paciência e a visão mais objetiva da realidade.

Poucos trabalham esse componente, de modo que se interrogados a respeito de seus objetivos, provavelmente responderão o que não gostariam.

O domínio pessoal objetiva que o indivíduo descubra quais as coisas que lhe são importantes, conduzindo sua vida de acordo com suas aspirações. 


\section{iii. Modelos mentais}

Os modelos mentais podem ser definidos como preconceitos, generalizações, ou seja, são fatores ou imagens que nos influenciam na maneira de agir e de encarar o mundo.

Assim sendo, encontramo-nos de frente com um componente existente em várias áreas e onde os mesmos não permite o avanço da empresa e das pessoas que nela trabalham, pois a existência de um pré-julgamento inviabiliza o novo.

\section{iv. Objetivo comum}

O estabelecimento de meta, valores e compromissos devem estar sempre explícito, transcrevendo caminhos para que os mesmos possam ter êxito.

Tal objetivo precisa ser compartilhado em toda a empresa, permitindo que um determinado funcionário saiba que sua função é uma parcela para construir um produto que atinja a meta da empresa e de todos aqueles que estão nela contidos.

\section{v. Aprendizado em grupo}

$\mathrm{O}$ aprendizado em equipe produz resultados excelentes em conjunto e seus integrantes se desenvolvem com maior rapidez no sentido individual.

A prática do raciocínio em grupo propicia diálogos construtivos, onde é importante a presença de opiniões diversas para juntos chegarem a uma conclusão de qual a melhor solução para a situação em questão.

É fundamental que os cinco componentes acima citados sejam trabalhados conjuntamente. Para isso é muito importante o desenvolvimento do raciocínio sistêmico, pois é com ele que há a integração dos demais.

Dentro de uma empresa o gerenciamento deve ser trabalhado de cima para baixo (do diretor ao operador) devendo atingir todos os níveis da empresa. A visão organizacional deve ser incorporada por cada membro constituinte do serviço e as experiências devem ser trocadas de forma a obter melhorias no sistema. 
Para a implantação do programa de gerenciamento em um serviço é extremamente importante desenvolver um objetivo comum, assim como a remoção de barreiras das pessoas envolvidas. A comunicação deve ser realizada em todos os níveis e a equipe necessita passar por treinamentos de modo contínuo. Atender as necessidades do cliente com o objetivo de satisfazê-lo cada vez mais. A realização do trabalho em equipe (duas cabeças pensam melhor que uma) proporciona melhor rendimento para o indivíduo como também para a empresa. Após a introdução destas ações é necessário que seja realizada avaliação e melhoria contínua.

Para avaliação da qualidade da água tratada algumas empresas utilizam-se de índices de performance da qualidade da água com a finalidade de melhor gerenciar seu processo. Esses índices são calculados à partir de variáveis tais como turbidez, número de coliformes, cloro residual, flúor e $\mathrm{pH}$, às quais são atribuídas pesos. Tal metodologia auxilia o gerenciamento, porém o emprego desta ferramenta não significa que tais índices de performance sejam confiáveis, sabido que uma mesma empresa apresenta 3 índices diferentes: IQ, IPQ e IP (índice de qualidade, índice de performance de qualidade e índice de performance respectivamente). Estes índices apresentam pesos diferenciados para mesmos parâmetros, o que gera dúvida à respeito da confiabilidade da análise de qualidade da água tratada. ${ }^{3}$

\subsection{Legislação Pertinente às ações das ETA}

\subsubsection{Lei de proteção dos mananciais}

O Código Florestal, instituído pela Lei Federal N. ${ }^{\circ}$ 4771, de 15 de setembro de 1965, contém vários dispositivos de proteção dos recursos hídricos,

3 TEIXEIRA, B. A. N; SALVADOR, N.B.; CORDEIRO, J. S. (1997), realizaram levantamento dos parâmetros e dos pesos por eles apresentados no cálculo dos índices de qualidade e constataram que existem vários índices, os quais consideram diferentes variáveis e estas recebem pesos diferenciados por cada equipe que o tenha definido, sem nenhum embasamento teórico. A maior dificuldade dos pesquisadores foi de encontrar material teórico no qual pudessem se orientar. 
particularmente no tocante à preservação da vegetação ciliar ao longo das margens dos cursos d'água. Foram estabelecidas faixas de proteção de diversas larguras, estipuladas em função da largura do curso a ser protegido, e onde deveria ser mantida a vegetação natural permanente. A fiscalização do Código Florestal foi atribuída ao IBDF - Instituto Brasileiro de Desenvolvimento Florestal do Ministério da Agricultura e às Polícias Florestais Estaduais, que realizam esta tarefa atualmente em consonância com os órgãos de proteção do meio ambiente.

Em 1979, foram criados ao nível federal, os Comitês Executivos de Estudos Integrados de Bacias Hidrográficas, os quais apresentavam composição variada, abrangendo representantes de diversos campos de atuação ligadas direta ou indiretamente aos recursos hídricos, sendo de extrema importância para o desenvolvimento da política no Brasil. Com isto, teve início uma nova fase, caracterizada por processo de gestão integrada dos recursos hídricos, sob enfoque interdisciplinar, levando em conta os múltiplos fatores envolvidos e sua diversidade.

\subsubsection{Lei das concessões}

Na Constituição de 1988 formulou-se o artigo 175 que trata da concessão dos serviços de utilidade pública com o intuito de promover a desestatização. Com muito pouco efeito prático, o mesmo teve que ser complementado com a Lei Federal n. ${ }^{\circ}$ 8987 de fevereiro de 1995.

A Lei n. 8987 foi resultado de vários projetos apresentados, entretanto apresenta algumas falhas, sendo uma delas sobre a política tarifária, a qual admite que o julgamento da concessão de serviços públicos seja realizado por um dos seguintes critérios:

- pelo menor valor da tarifa do serviço público a ser prestado;

- pela maior oferta, aos casos de pagamento ao poder concedente pela outorga da concessão;

- pela combinação dos dois critérios acima descritos.

No artigo 35 da Lei das Concessões fica estabelecido que o concedente poderá extinguir a concessão caso a empresa concessionária não cumpra os regulamentos conforme estabelecido em contrato. 


\subsubsection{Resolução CONAMA N. ${ }^{\circ} 20$ de 18/06/1986}

A Lei Federal N. ${ }^{\circ}$ 6938, de 31 de agosto de 1981, definiu a Política Nacional do Meio Ambiente e o CONAMA - Conselho Nacional do Meio Ambiente. Esta Lei foi regulamentada pelo Decreto N. 99.274 em 1990. A política teria por objetivo a preservação, a melhoria e a recuperação da qualidade ambiental, dentro dos seguintes princípios: ação governamental na manutenção do equilíbrio ecológico, considerando o meio ambiente como um patrimônio público, de uso coletivo; planejamento e fiscalização do uso dos recursos do solo, do subsolo, da água e do ar, que deverá ser feito de forma racional; proteção dos ecossistemas, com a preservação de áreas representativas; controle e zoneamento de atividades potencial ou efetivamente poluidoras; desenvolvimento de tecnologias voltadas ao uso racional e à proteção dos recursos ambientais; acompanhamento do estado da qualidade ambiental; recuperação de áreas degradadas e proteção daquelas ameaçadas de degradação; educação ambiental a todos os níveis de ensino e educação sanitária.

A execução da Política é realizada pelo SISNAMA (Sistema Nacional do Meio Ambiente), CONAMA (Conselho Nacional do Meio Ambiente), IBAMA (Instituto Brasileiro do Meio Ambiente e dos Recursos Naturais), e entidades estaduais responsáveis pela execução de programas e projetos de controle e fiscalização de atividades suscetíveis de degradarem o meio ambiente, e órgãos locais - entidades municipais responsáveis pelo controle e fiscalização dessas atividades.

A Resolução N. 20 do CONAMA classifica os corpos d'água e estabelece os padrões de qualidade dos mesmos de modo a assegurar seus usos preponderantes, não podendo os efluentes conferir ao corpo receptor características em desacordo com o seu enquadramento nesta resolução.

Considerando ser indispensável prevenir a ocorrência de acidentes, que em várias partes do país têm poluído rios e extinguido a vida aquática, chegando até mesmo, a paralisar o abastecimento d'água às populações de cidades inteiras, baixouse a Portaria Minter N.o 124 em 1980, a qual fixa a distância mínima entre cursos d'água e indústrias potencialmente poluidoras ou estruturas que armazenam substâncias capazes de causar poluição hídrica. Esta portaria exige a proteção de 
depósitos projetados ou construídos acima do solo para receber líquidos potencialmente poluentes e estabelece que quando não for possível atender os itens acima citado ficará a cargo do órgão estadual de controle do meio ambiente substituir as exigências por outras medidas preventivas e igualmente seguras.

\subsubsection{Portaria N. ${ }^{\circ} 36 / G M$ de 19/01/1990}

De acordo com o Ministério da Saúde, água potável é aquela com qualidade adequada ao consumo humano. Através da Portaria N. 36 de 19 de janeiro de 1990, estabeleceu-se o padrão de potabilidade da água destinada ao consumo humano. O padrão aprovado por esta portaria constitui o limite máximo para cada elemento ou substância química, não estando considerados eventuais efeitos sinérgicos entre eles e outros elementos ou substâncias.

\subsubsection{Construção da ETA}

A Norma NBR-592 é empregada para a elaboração de projetos de Sistemas de Tratamento de Água para Abastecimento. Esta Lei estabelece o campo de aplicação, elementos e atividades necessários para o desenvolvimento do projeto. Define área necessária para implantação do projeto, processos de tratamento, disposição e dimensionamento das unidades dos processos e dos sistemas de conexão das mesmas entre si e faz observações sobre casa de química, consumo de produtos químicos e preparação e dosagem de sulfato de alumínio.

\subsubsection{Produtos químicos}

Os produtos químicos empregados no tratamento de água para abastecimento devem obedecer Normas elaboradas pela ABNT as quais expressam o grau de pureza que o produto deve conferir. 
Para os produtos químicos empregados no tratamento da água de abastecimento são especificadas as normas apresentadas na Tabela 2.

Tabela 2: Produtos químicos empregados no tratamento de água e suas referidas normas

\begin{tabular}{|l|l|}
\hline \multicolumn{1}{|c|}{ Produto Químico } & \multicolumn{1}{c|}{ Normas } \\
\hline $\begin{array}{l}\text { sulfato de alumínio } \\
\text { (amostragem) }\end{array}$ & NBR 11.177 \\
\hline sulfato de alumínio & $\begin{array}{l}\text { NBR 11.176; 11.178; 11.179; 11.180; 11.181 e } \\
11.182\end{array}$ \\
\hline cloreto férrico & NBR 7.546 \\
\hline cal virgem e hidratada & NBR 10.790 \\
\hline cloro & NBR 12.143 e 12.144 \\
\hline polímero & NBR 7.977; 11.934 e 13.176 \\
\hline extintor de cal & NBR 10.790 e 12.805 \\
\hline
\end{tabular}

Para os insumos ácido fluossilícico, fluossilicato de sódio e amido de batata nada foi encontrado em especificação pela ABNT.

\subsubsection{Padrão de emissão}

A Lei N. 997 do Estado de São Paulo de 31 de maio de 1976 dispõe sobre o controle da poluição do meio ambiente. São regulamentados nesta lei o tipo de despejo que poderá ser lançado no corpo de água de forma que o mesmo não tenha suas características e classificação alteradas.

\subsubsection{Segurança no Trabalho}

Pesquisou-se norma referente à segurança do trabalho realizado em estações de tratamento de água, porém constatou-se que no momento não existe norma específica para este setor, apenas legislação que engloba todas as atividades. 
A partir de tal constatação procurou-se alguma literatura que apresentasse recomendações sobre o assunto. Foi encontrado um livro publicado pela CETESB com o título de Manual Para Operadores de Estação de Tratamento de Água. Este manual diz que: "os acidentes não acontecem; são causados por indiferença, falta de atenção, negligência, falta de manutenção, ignorância, falta de cuidado, pouca iluminação, supervisão defeituosa e maus projetos e arranjo de equipamentos".

Os riscos de acidentes dentro das ETA listados pelo Manual são: quedas, choque elétrico, ferramentas com corte, infeções, asfixia, vapores e gases tóxicos ou inflamáveis e socorros inadequados.

Para os acidentes citados acima, o Manual Para Operadores de Estações de Tratamento faz as seguintes recomendações:

\section{“1. Quedas}

As escadas devem possuir corrimão. As escadas de mão devem ter degraus que vão permitir escorregamento que sejam apoiadas no fundo e amarradas. A escada para os tanques de lavagem devem ter uma "gaiola" de proteção ao longo de todo o seu comprimento. Cintos de segurança são bastante recomendáveis em muitas situações.

\section{Choque elétrico}

Um cordão elétrico deve ter um soquete a prova de choque, com uma proteção na lâmpada e não deve ter partes desfiadas ao longo de seu comprimento. Deve-se considerar que as tensões acima de 50 volts podem ser fatais quando é formado um bom terra. As ferramentas elétricas portáteis devem possuir um terceiro fio para conectar com a terra a caixa externa ou carcassa. Luvas e botas de borracha são aconselháveis.

\section{Infeções}

Muitos operadores realizam testes bacteriológicos de laboratório. O esvaziamento e o enchimento de tubos de fermentação podem ser perigosos. Nunca 
se está certo de que organismos prejudiciais não estão se desenvolvendo nos tubos. Evitar que espirre líquidos sobre a pele e/ou nos olhos. Evitar fumar durante essas operações. Quando se termina o trabalho é conveniente lavar as mãos cuidadosamente, especialmente antes de comer.

\section{Asfixia}

Quando se penetra em fossas profundas, poços de visitas secos, pode ocorrer asfixia. Isso ocorre devido a uma deficiência de oxigênio, pois normalmente o ar contém $21 \%$ de oxigênio e se essa porcentagem cai para $18 \%$, muitos homens encontram dificuldade em respirar. Qualquer sentimento de intranqüilidade ou apreensão deve servir de advertência para que as pessoas saiam do poço. Câmaras de floculação profundas devem ser visitadas com cuidado especialmente se o lodo permanecer nelas durante algum tempo após a drenagem.

\section{Explosões}

Fossas profundas, poços de visita secos, etc. podem conter gás metano, que forma uma atmosfera explosiva quando presente em percentagens de 5 a $15 \%$. Onde há decomposição de restos de vegetais pode ocorrer a formação de metano.

\section{Poeiras tóxicas}

Máscaras com filtros devem ser utilizadas quando sacos de produtos químicos caem em silos dos dosadores a seco. Quando se manipulam fluoreto ou fluorsilicato de sódio deve-se providenciar arranjos especiais.

\section{Produtos químicos perigosos}

Cloreto de sódio deve ser manipulado em uma sala que não contenha material combustível. Ácidos fortes nunca devem ser postos em contato com cloritos. O 
carvão ativado proporciona risco de incêndio. Ao manipular ácido fluorsilícico, deve-se ter sempre a mão uma garrafa com "spray" de bicarbonato de sódio. Queimaduras com ácidos que contenham flúor não aparecem imediatamente, mas apenas quando já estejam bastante doloridas. Deve-se identificar a fonte de qualquer odor de cloro e remover a fonte causadora. Uma máscara de gás deve ser mantida no lado de fora da sala de cloradores. Todo operador deve saber como efetuar a "ressuscitação" boca à boca. Um equipamento para respiração boca à boca é uma necessidade.

8. Auxílio inadequado

O transporte de tubos comprimidos e a elevação de objetos pesados causam acidentes freqüientemente. A elevação de objetos pesados pode provocar hérnias ou ferimentos aos pés se houver queda dos objetos. Objetos pesados ou desajeitados nunca devem ser levantados sem auxílio adequado".

Do levantamento realizado pode-se perceber que as tecnologias de tratamento de água apresentam várias pesquisas desenvolvidas, porém pouco tem sido aproveitado pelos responsáveis das ETA.

Os financiamentos fornecidos a estes serviços encontram-se relativamente insuficientes. De acordo com artigos obtidos a administração dos serviços de abastecimento de água realizada pelo setor privado não tem se mostrado satisfatória, devido o interesse das empresas estar direcionado a grandes centros, de modo a garantir que seu investimento tenha lucro certo, o que deixa de priorizar a questão social e o custo que a população terá que pagar pela qualidade do produto recebido.

As leis e normas existentes abrangem praticamente todo o sistema, nota-se a inexistência de regulamentação específica para segurança do trabalhador de ETA. De todas as leis pertinentes ao tratamento de água é claramente percebida a preocupação em atender o padrão de potabilidade da Portaria 36 GM/1990.

A existência de leis de proteção dos mananciais não garante que os mesmos estão sendo protegidos, para tanto deve-se estabelecer programas e ações preventivas que promovam a manutenção da qualidade do corpo d'água. 


\section{MÉTODOS E MATERIAIS}

Para a análise do funcionamento dos sistemas de abastecimento de água procurou-se estudar e levantar o estado da arte sobre o desenvolvimento da questão gerencial. Para tanto foram feitos estudos sobre o aspecto gerencial de empresas e como a indústria de abastecimento de água se comporta sobre o tema. Fez-se uma extensa revisão bibliográfica sobre questões técnicas e legislações pertinentes.

Foram selecionados os locais de visita. Para tal considerou-se a proximidade destas à cidade de São Carlos e procurou-se definir Estações de Tratamento de Água com características gerenciais diversas, tais como: sistemas autônomos, privados e públicos estaduais.

Elaborou-se um questionário para levantamento de dados referentes aos últimos 5 anos de funcionamento das ETA selecionadas, visando dispor de informações amplas a respeito da forma de trabalho dos sistemas. O questionário desenvolvido encontra-se no Anexo C.

Realizou-se levantamento das pessoas responsáveis pelos serviços de água, bem como dos "gerentes" das ETA. Entrou-se em contato com os mesmos através de carta, na qual a pesquisa que seria desenvolvida foi mostrada, bem como sua importância.

As visitas foram agendadas e cada uma teve duração de aproximadamente uma semana.

Os dados enfocados no questionário referem-se as várias etapas do sistema tais como:

1. Manancial

- Tipo

- Características da água bruta

- Monitoramento da qualidade da água bruta

- Proteção 
- Manutenção da qualidade

2. ETA

- Tipo

- Operação

- Acompanhamento da qualidade da água (decantada, filtrada, tratada)

- Características físicas das unidades de tratamento de água

- Geração de resíduos e limpeza dos tanques de produção (decantadores e filtros)

- Levantamento das bombas existentes

- Consumo de energia elétrica

- Automação operacional

- Caracterização dos laboratórios físico-químicos e bacteriológicos

- Utilização dos dados de laboratórios

3. Insumos

- Insumos utilizados e pontos de aplicação

- Controle de qualidade dos produtos químicos

- Previsão e controle de estoque de produtos químicos

- Consumo de produtos químicos

- Armazenamento de produtos químicos

- Especificações técnicas dos produtos químicos

- Fornecedores dos produtos químicos

4. Recursos humanos

- Qualificação dos recursos humanos

- Treinamento oferecido pela empresa aos operadores

- Condições de segurança do trabalho 
Foram visitadas 11 ETA dos mais variados tipos, nas quais obteve-se informações através do questionário e do acompanhamento das condições operacionais "in loco".

As ETA visitadas apresentam características diferenciadas quanto ao tipo de coagulante, vazão tratada pela estação, número de decantadores e de filtros, sendo todas abastecidas por captação superficial.

A Tabela 3 apresenta as características das ETA com relação ao tipo de coagulante empregado, número de decantadores e número de filtros.

Tabela 3: Características das ETA: tipo de coagulante, número de decantadores e filtros

\begin{tabular}{|c|c|c|c|}
\hline ETA & Coagulante Primário & Número & Número filtros \\
\hline A & Sulfato de alumínio & 4 de alta taxa & 10 unidades duplas \\
\hline B & Cloreto férrico & 2 de alta taxa & 6 unidades duplas \\
\hline C & Sulfato de alumínio & 2 convencionais & 6 unidades duplas \\
\hline D & Sulfato de alumínio & 6 convencionais & 2 unidades duplas e 7 unidades \\
\hline E & Sulfato de alumínio & 2 convencionais & 3 unidades duplas \\
\hline F & Sulfato de alumínio & 2 de alta taxa & 4 unidades duplas \\
\hline G & Cloreto férrico & 4 convencionais & 11 unidades duplas \\
\hline H & Sulfato de alumínio & 4 convencionais & 10 unidades duplas \\
\hline I & Cloreto férrico & 4 convencionais & 4 unidades duplas e 4 simples \\
\hline J & Cloreto férrico & 2 convencionais & 6 unidades duplas \\
\hline L & Sulfato de alumínio & 3 convencionais & 7 unidades duplas \\
\hline
\end{tabular}

$\mathrm{Na}$ Tabela 4, apresentam-se dados das estações de tratamento de água visitadas referentes à população da cidade abastecida, renda média do chefe do domicílio, vazão nominal da estação, manancial, classe dos mesmos e adução àETA. 
Tabela 4: Caracterização das ETA visitadas

\begin{tabular}{|c|c|c|c|c|c|c|}
\hline ETA & $\begin{array}{l}\text { População } \\
\text { (hab.) })^{1}\end{array}$ & $\begin{array}{l}\text { Renda média } \\
\text { mensal do chefe } \\
\text { do domicílio } \\
\text { (U\$) }\end{array}$ & $\begin{array}{l}\text { Vazão tratada } \\
\qquad(1 / \mathrm{s})\end{array}$ & Manancial & ${\text { Classificação dos } \operatorname{Rios}^{3}}^{3}$ & Distância captação à ETA \\
\hline A & 167.945 & 473,90 & 850 & $\begin{array}{l}\text { Rio Piracicaba (barragem } \\
\text { antecedendo captação) }\end{array}$ & Classe 2 & $3 \mathrm{~km}$ e $10 \mathrm{~km}$ respectivamente \\
\hline $\mathrm{B}$ & 168.468 & 438,86 & 580 & Rio Cruzes e Anhumas & Classe 2 & $3 \mathrm{~km}$ e $10 \mathrm{~km}$ respectivamente \\
\hline $\mathrm{C}$ & 100.646 & 338,44 & 220 & Ribeirão Pitangueiras & Classe 2 & $300 \mathrm{~m}$ \\
\hline $\mathrm{D}$ & 267.235 & 379,01 & 1000 & $\begin{array}{c}\text { Rio Canoas, Ribeirão Pouso } \\
\text { Alegre e Ribeirões Macacos, } \\
\text { Grimaldi e Natal }\end{array}$ & Classe 2 & $\begin{array}{c}14,3 \mathrm{~km} ; 13,4 \mathrm{~km} \mathrm{e} 3,6 \mathrm{~km} \\
\text { respectivamente }\end{array}$ \\
\hline $\mathrm{E}$ & 33.114 & 301,53 & 100 & Ribeirão do Jardim & Classe 2 & $100 \mathrm{~m}$ \\
\hline $\mathrm{F}$ & 230.348 & 363,30 & 880 & Rio Jaguari e Ribeirão do Pinhal & Classe 2 & $19 \mathrm{~km}$ \\
\hline $\mathrm{G}$ & 302.886 & 460,94 & 850 & $\begin{array}{l}\text { Rio Piracicaba (barragem à } \\
\text { montante do rio) }\end{array}$ & Classe 2 & $2 \mathrm{~km} \mathrm{e} 600 \mathrm{~m}$ \\
\hline $\mathrm{H}$ & 302.886 & & 1100 & Rio Corumbataí & Classe 2 & $5 \mathrm{~km}$ \\
\hline $\mathrm{I}$ & 153.389 & 402,61 & 500 & Ribeirão Claro & Classe 2 & $3 \mathrm{~km}$ \\
\hline $\mathbf{J}$ & 153.389 & & 500 & Rio Corumbataí & Classe 2 & $2 \mathrm{~km}$ \\
\hline $\mathrm{L}$ & 175.517 & 416,82 & 400 & Rio Feijão, Espraiado e Galdino & Classe 2 & $16 \mathrm{~km}, 8 \mathrm{~km}$ e $3 \mathrm{~km}$ respectivamente. \\
\hline
\end{tabular}

NOTAS: $\quad 1$ - Fonte IBGE - censo 1996.

2 - Renda média do chefe de domicílio segundo o IBGE, corresponde a soma de todos os rendimentos dos chefes dos domicílios particulares permanentes dividida pelo total de chefes dos domicílios particulares permanentes. A informação está expressa em cruzeiros do ano de 1991 e foi obtida no endereço http:/www.sidra.ibge.gov.br . Esta renda foi convertida para dólar, empregando-se a cotação média do dólar no ano de 1991 (dados obtidos por http:/serviços.regra.com.br/dolar/busca_data.htm).

3 - Classificação exigida pela Legislação Estadual - Controle da Poluição Ambiental do Estado de São Paulo. CETESB - Série Documentos (atualizado até 03/92). São Paulo 
Na Tabela 5, são apresentadas as características da água bruta em termos de $\mathrm{pH}$, turbidez e cor.

\section{Tabela 5: Caracterização da Água Bruta das ETA visitadas}

\begin{tabular}{|c|c|c|c|}
\hline \multirow[b]{2}{*}{ ETA } & \multicolumn{3}{|c|}{ Água Bruta } \\
\hline & $\mathrm{pH}^{1}$ & $\begin{array}{l}\text { Turbidez } \\
\text { (uT) }\end{array}$ & $\begin{array}{c}\text { Cor Aparente } \\
\text { (uC) }\end{array}$ \\
\hline $\mathrm{A}^{2}$ & $6.9-7.0$ & & \\
\hline B & 6.9-7.1 & $22-114$ & $118-457$ \\
\hline $\mathrm{C}^{3}$ & $6.6-7.0$ & $18-40$ & $40-90$ \\
\hline $\mathrm{D}$ & $5.7-7.6$ & $12-457$ & $60-500$ \\
\hline $\mathrm{E}$ & $6,5-6,9$ & $10-40$ & $40-200$ \\
\hline $\mathrm{F}$ & $6.8-7.0$ & $10-140$ & $10-140$ \\
\hline $\mathrm{G}$ & $6.6-7.1$ & $11-138$ & $40-695$ \\
\hline $\mathrm{H}$ & $6.8-7.0$ & $7-110$ & $60-485$ \\
\hline I & $6,5-7,9$ & $11-95$ & $81-550$ \\
\hline $\mathbf{J}$ & $6.5-7,5$ & $13-373$ & $107-560$ \\
\hline $\mathrm{L}$ & $6,2-7,1$ & $10-41$ & $91-345$ \\
\hline
\end{tabular}

NOTAS: 1. Os intervalos de pH, turbidez e cor são referentes aos valores mínimos e os máximos no ano de 1996.

2. A ETA A não forneceu os valores dos parâmetros.

3. Os intervalos de $\mathrm{pH}$, turbidez e cor da água bruta que abastece a ETA C são referentes aos valores mínimos e os máximos no ano de 1988.

Na Tabela 6, são mostrados os aspectos operacionais observados durante as visitas às ETA. 
Tabela 6: Aspectos observados nas cidades visitadas

\begin{tabular}{|c|c|c|}
\hline \multicolumn{2}{|c|}{ Objeto de estudo } & Observações \\
\hline Manancial & & $\begin{array}{l}\text { - } \quad \text { Condições dos mananciais } \\
\text { - } \quad \text { Preservação e programa de recuperação dos mananciais }\end{array}$ \\
\hline Água bruta & & - $\quad$ Qualidade da água bruta nos últimos 5 anos \\
\hline \multirow[t]{7}{*}{ ETA } & geral & 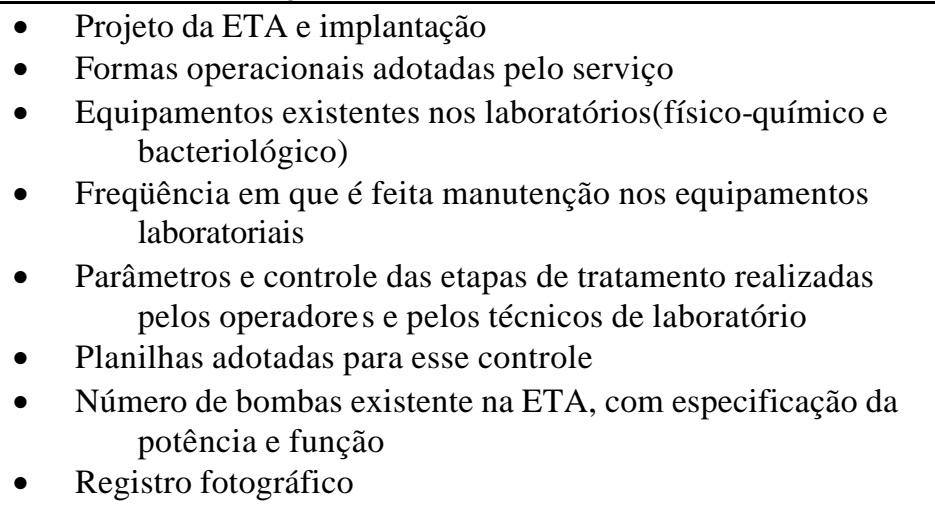 \\
\hline & $\begin{array}{l}\text { Mistura } \\
\text { rápida }\end{array}$ & $\begin{array}{l}\text { Tipo de mistura, pH de coagulação, gradiente de velocidade, } \\
\text { tempo de mi stura }\end{array}$ \\
\hline & Mistura lenta & $\begin{array}{l}\text { Tipo de mistura, número de unidades, dimensão, gradiente de } \\
\text { velocidade, tempo de mistura }\end{array}$ \\
\hline & Decantação & $\begin{array}{l}\text { Tipo, dimensão, freqüência e tempo de limpeza, tipo de fundo, } \\
\text { como é realizada a limpeza }\end{array}$ \\
\hline & Filtração & $\begin{array}{l}\text { Meio filtrante, intervalo entre lavagens, vazão empregada e } \\
\text { duração da lavagem, método de lavagem, de onde provem a água } \\
\text { de lavagem }\end{array}$ \\
\hline & Desinfecção & Ponto de aplicação \\
\hline & $\begin{array}{l}\text { Correção do } \\
\mathrm{pH}\end{array}$ & Ponto de aplicação \\
\hline $\begin{array}{l}\text { Produtos } \\
\text { químicos }\end{array}$ & & $\begin{array}{l}\text { - } \text { Armazenamento e preparo dos produtos químicos utilizados } \\
\text { - } \quad \text { Transporte e embalagem } \\
\text { - } \quad \text { Critérios para aquisição dos produtos químicos } \\
\text { - } \quad \text { Controle da qualidade dos produtos químicos adquiridos } \\
\text { - } \quad \text { Fornecedores dos produtos químicos } \\
\text { - } \quad \text { Consumo } \\
\text { - } \quad \text { Local de aplicação }\end{array}$ \\
\hline $\begin{array}{l}\text { Recursos } \\
\text { humanos }\end{array}$ & & $\begin{array}{ll}\text { - } & \text { Qualificação do pessoal responsável pelo tratamento } \\
\text { - } & \text { Qualificação dos operadores } \\
\text { - } & \text { Treinamento dos operadores e dos responsáveis pelo sistema } \\
\text { - } & \text { Turno de trabalho executado pelo operador } \\
\text { - } & \text { Cursos de aperfeiçoamento do pessoal } \\
\end{array}$ \\
\hline Segurança & & $\begin{array}{ll} & \text { Programas de segurança do trabalho envolvido } \\
\text { - } & \text { Equipamentos disponíveis } \\
\end{array}$ \\
\hline Água tratada & & $\begin{array}{ll} & \text { Controle da qualidade } \\
\text { - } & \text { Acompanhamento na rede de distribuição } \\
\end{array}$ \\
\hline Gerenciamento & & $\begin{array}{l}\text { - } \quad \text { Organograma administrativo do serviço de água } \\
\text { - } \quad \text { Programa de perdas de água na ETA } \\
\text { - } \quad \text { Utilização dos dados levantados nas análises laboratoriais } \\
\text { - } \quad \text { Automação das ETA e utilização de computadores } \\
\end{array}$ \\
\hline
\end{tabular}




\section{RESULTADOS E DISCUSSÕES}

Neste capítulo serão apresentados os dados levantados durante o desenvolvimento da pesquisa. Esses não foram levantados para serem utilizados na elaboração de projetos de estação de tratamento de água, e sim para dar direcionamento aos gerentes de ETA sobre quais pontos poderiam auxiliá-los na gestão da indústria da água.

\subsection{Manancial}

A qualidade dos mananciais que abastecem as ETA estudadas foi avaliada através de dados resultantes de análises realizadas nos últimos anos em alguns dos sistemas. Ressalta-se no entanto, que a maioria dos serviços não possui dados que permitam avaliação mais profunda.

Na Tabela 7, apresentam-se os resultados das condições dos mananciais no período da visita, a verificação da existência ou não de dados histórico das características da água bruta e se haviam programas e/ou ações com o objetivo de proteger esses mananciais. 
Tabela 7: Condições atuais, Controle de qualidade e proteção dos mananciais

\begin{tabular}{|c|c|c|c|}
\hline \multirow{2}{*}{ ETA } & \multicolumn{3}{|c|}{ Manancial } \\
\hline & Condições atuais & Dados históricos das características da água bruta & Programas/Ações de proteção \\
\hline $\bar{A}$ & Florescimento de algas & Não tem dados históricos. & Não possui. \\
\hline B & $\begin{array}{l}\text { Assoreado e em estágio de manutenção (rio } \\
\text { sendo dragado) }\end{array}$ & Dados his tóricos de 3 anos(outros 2 em arquivo morto). & Não possui. \\
\hline $\mathrm{C}$ & $\begin{array}{l}\text { Assoreado e em estágio de } \\
\text { manutenção(retirada de folhas e areia com } \\
\text { máquina e homens) }\end{array}$ & Não tem dados históricos. & Não possui. \\
\hline $\bar{D}$ & $\begin{array}{l}\text { Assoreado e em estágio de } \\
\text { manutenção(draga no rio) }{ }^{1}\end{array}$ & $\begin{array}{l}\text { Dados históricos de } 1 \text { ano(outros } 4 \text { anos foram emprestados e } \\
\text { não se sabe para quem). } \\
\text { Existe monitoramento dos rios. }\end{array}$ & Não possui. \\
\hline $\mathrm{E}$ & $\begin{array}{l}\text { Manutenção regular. Não encontra-se } \\
\text { assoreado. }\end{array}$ & Não tem dados históricos. & Não possui. \\
\hline $\mathrm{F}$ & Aparecimento de algas & Dados históricos de 1 ano(outros 4 no arquivo morto). & $\begin{array}{l}\text { Sim. Criação de lei municipal de proteção ao } \\
\text { Ribeirão do Pinhal que é um manancial } \\
\text { alternativo através de projeto enviado à } \\
\text { Prefeitura pelo serviço de água }\end{array}$ \\
\hline $\bar{G}$ & $\begin{array}{l}\text { Florescimento de algas, alto índice de } \\
\text { poluição }\end{array}$ & Dados históricos de 5 anos. & Não possui. \\
\hline $\mathrm{H}$ & Ocorrência de assoreamento & Dados históricos de 5 anos. & $\begin{array}{l}\text { Sim. Projeto de reflorestamento das margens } \\
\text { do rio. Trabalho em conjunto do serviço de } \\
\text { abastecimento de água e dos usineiros da } \\
\text { região. }\end{array}$ \\
\hline $\mathrm{T}$ & Assoreado e sem manutenção & Não tem dados históricos. & Não possui. \\
\hline $\mathrm{J}$ & Assoreado e relativa manutenção & Dados históricos de 2 anos. & Não possui. \\
\hline $\mathrm{L}$ & $\begin{array}{l}\text { Ocorrência de assoreamento. Relativa } \\
\text { manutenção. }\end{array}$ & Dados históricos de 5 anos. & Não \\
\hline
\end{tabular}

NOTA: $\quad$ 1- Não foi possível durante a visita à estação de tratame nto de água ir até a captação. As informações aqui descritas foram fornecidas por responsáveis da ETA e observando-se registro fotográfico. 
Seis das ETA estudadas situam-se na Bacia do Rio Piracicaba. Estudos realizados pela Secretaria do Meio Ambiente do Estado de São Paulo em 1990 mostraram que, na época, um dos sistemas estudados utilizava água de manancial fora dos limites exigidos pela legislação, como mostra a Tabela 8.

Tabela 8: Situação dos corpos d'agua da Bacia do Rio Piracicaba em 1990.

\begin{tabular}{|c|c|}
\hline ETA & $\begin{array}{c}\text { Classe atual dos Rios à } \\
\text { montante da captação }\end{array}$ \\
\hline A & 2 \\
\hline F & 2 \\
\hline G & 3 \\
\hline H & 2 \\
\hline I & 2 \\
\hline J & 2 \\
\hline
\end{tabular}

Deve-se observar que alguns dos sistemas visitados não dispunham dos dados sistematizados, estando, em alguns casos, em "arquivos morto", emprestados, dificultando a possível análise histórica dos mesmos.

As ETA G e $\mathrm{H}$ possuem maior número de informações disponíveis. Através das informações obtidas nestas duas estações construíram-se os gráficos mostrados na 
Figura 10 e na Figura 11. Obteve-se as médias mensais de cada um dos parâmetros turbidez, cor aparente e oxigênio consumido. Com esses valores, foram montados gráficos que indicam o menor e o maior valor obtido em cada ano. Foram traçadas, também, curvas indicando as médias anuais e o consumo de coagulante anual por volume de água tratada.

Através desses gráficos pode-se perceber que existe tendência de aumento nos valores médios anuais de turbidez, cor aparente para a ETA $\mathrm{G}$ e pode-se também perceber tendência de aumento nos valores médios anuais de turbidez, cor aparente oxigênio consumido para a ETA H. Pode-se notar, também, um claro aumento no consumo anual do produto químico empregado no tratamento para ambas as estações. Assim, o cuidado em se saber a razão dessa ocorrência é problema 
gerencial que deve ser enfrentado. Várias podem ser as razões para essa tendência, que deveria estar sendo estudada com mais profundidade.

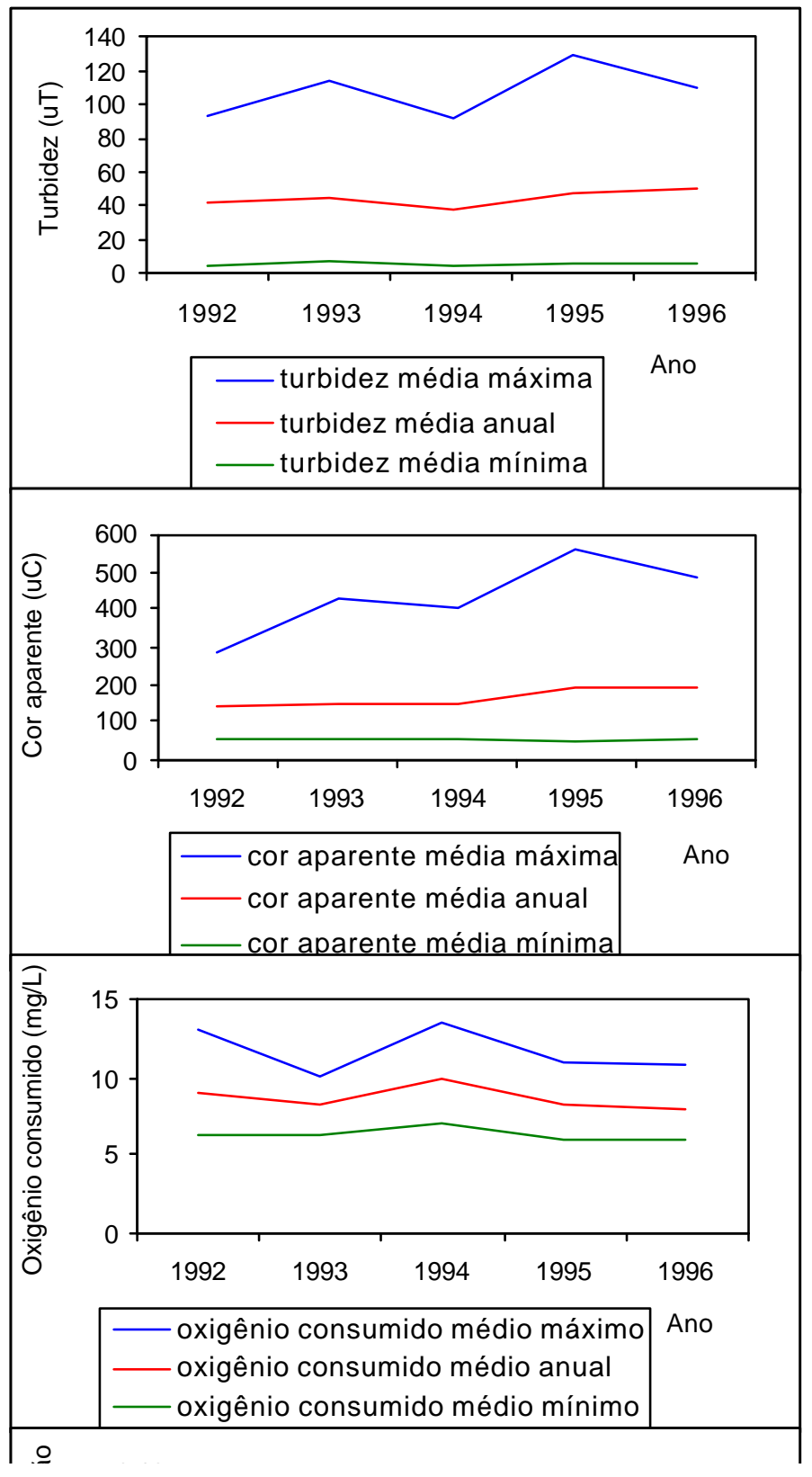


Figura 10: Características da água bruta que abastece a ETA G

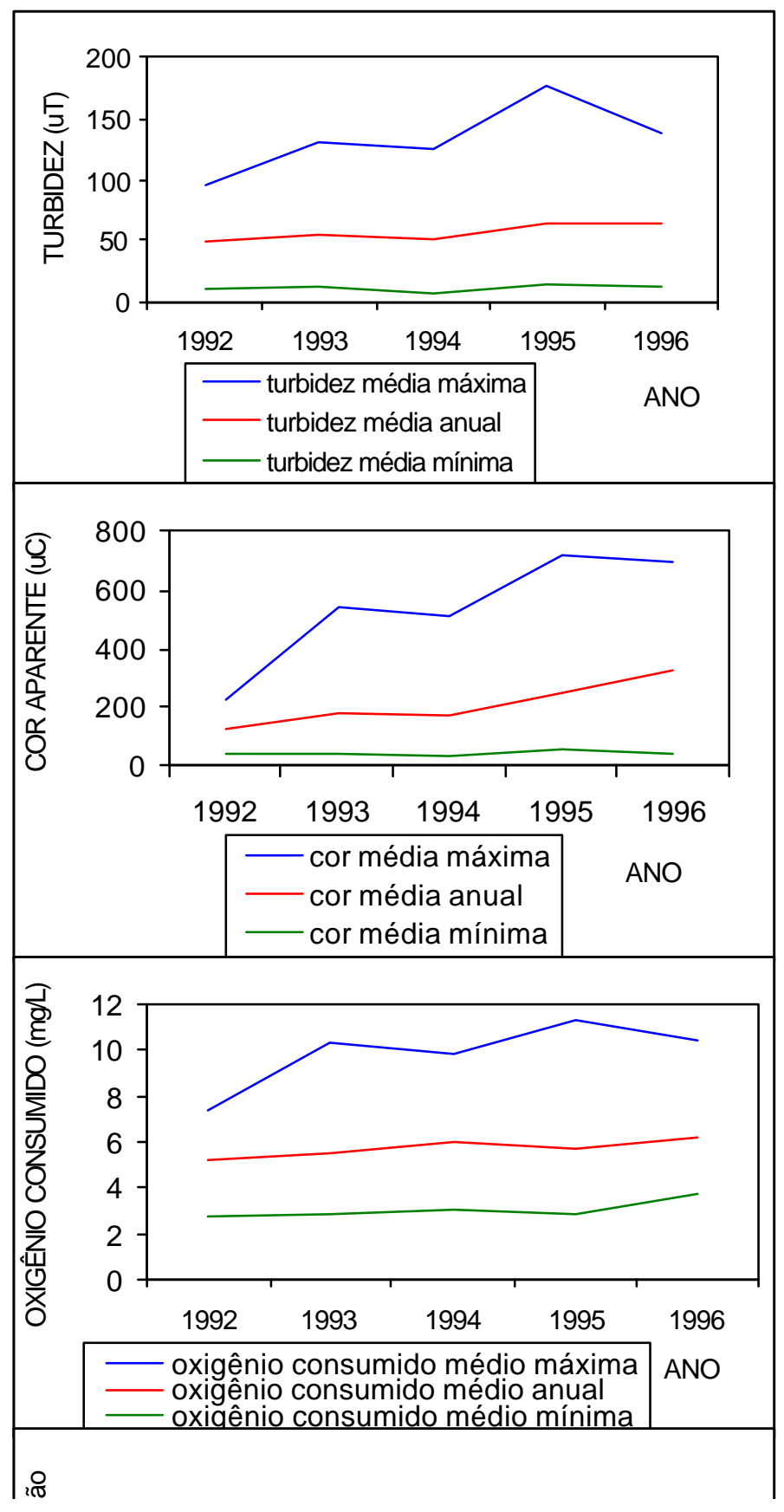




\section{Figura 12: Características da água bruta que abastece a ETA H}

Entre os anos de 1992 e 1996 o acréscimo de produto químico (kg) por metro cúbico de água tratada foi de $124 \%$ para a ETA G e $147 \%$ para a ETA $H$.

As informações apresentadas na Tabela 9 referem-se às análises laboratoriais de rotina que eram realizadas nas estações de tratamento de água na época em que foi realizada a visita. Infelizmente, são poucas as ETA que organizam e arquivam esses dados sistematicamente.

Conforme mostrado abaixo, os parâmetros analisados diariamente por todas as ETA visitadas são $\mathrm{pH}$, turbidez e cor aparente. A análise de ferro total é realizada em 64\% (7) das ETA visitadas. Os demais parâmetros são analisados em número menor de estações. Somente uma ETA visitada realiza a análise diária de acidez.

A ETA $\mathrm{F}$ realiza $100 \%$ das análises listadas. Observou-se que o estabelecimento desses parâmetros de rotina é fixado de maneira subjetiva, em função das condições aparentes da água bruta.

Tabela 9:Análises realizadas diariamente pelas estações de tratamento de água na água bruta.

\begin{tabular}{|c|c|c|c|c|c|c|c|c|c|c|c|c|}
\hline \multirow[b]{2}{*}{ Parâmetros } & \multicolumn{11}{|c|}{ ETA } & \multirow{2}{*}{$\begin{array}{c}\text { \% das ETA } \\
\text { que fazem a } \\
\text { análise }\end{array}$} \\
\hline & $\mathrm{A}$ & $\mathrm{B}$ & $\mathrm{C}$ & $\mathrm{D}$ & $E$ & $\mathrm{~F}$ & $\mathrm{G}$ & $\mathrm{H}$ & I & $\mathbf{J}$ & $\mathrm{L}$ & \\
\hline Turbidez & $\mathrm{X}$ & $\mathrm{X}$ & $\mathrm{X}$ & $\mathrm{X}$ & $\mathrm{X}$ & $\mathrm{X}$ & $\mathrm{X}$ & $\mathrm{X}$ & $\mathrm{X}$ & $\mathrm{X}$ & $\mathrm{X}$ & 100 \\
\hline Cor aparente & $\mathrm{X}$ & $\mathrm{X}$ & $\mathrm{X}$ & $\mathrm{X}$ & $\mathrm{X}$ & $\mathrm{X}$ & $\mathrm{X}$ & $\mathrm{X}$ & $\mathrm{X}$ & $\mathrm{X}$ & $\mathrm{X}$ & 100 \\
\hline $\begin{array}{l}\text { Oxigênio } \\
\text { consumido }\end{array}$ & & $\mathrm{X}$ & & & & $\mathrm{X}$ & $\mathrm{X}$ & $\mathrm{X}$ & & & $\mathrm{X}$ & 45 \\
\hline $\begin{array}{l}\text { Oxigênio } \\
\text { dissolvido }\end{array}$ & & & & & & $\mathrm{X}$ & & $\mathrm{X}$ & & & & 18 \\
\hline
\end{tabular}




\begin{tabular}{|c|c|c|c|c|c|c|c|c|c|c|c|c|}
\hline $\mathrm{pH}$ & $\mathrm{X}$ & $\mathrm{X}$ & $\mathrm{X}$ & $\mathrm{x}$ & $\mathrm{X}$ & $\mathrm{X}$ & $\mathrm{x}$ & $\mathrm{x}$ & $\mathrm{X}$ & $\mathrm{X}$ & $\mathrm{X}$ & 100 \\
\hline $\begin{array}{l}\text { Alcalinidade } \\
\text { total }\end{array}$ & & & & $\mathrm{X}$ & & $\mathrm{X}$ & $\mathrm{X}$ & $\mathrm{x}$ & & & $\bar{x}$ & 45 \\
\hline Ferro total & & $\mathrm{X}$ & & $\mathrm{X}$ & & $\mathrm{X}$ & X & $\mathrm{X}$ & $\mathrm{X}$ & $\mathrm{X}$ & & 64 \\
\hline Condutividade & & & & & & $\mathrm{X}$ & $\mathrm{x}$ & $\mathrm{x}$ & & & & 27 \\
\hline Acidez & & & & & & $\mathrm{X}$ & & & & & & 9 \\
\hline Dureza total & & $\mathrm{X}$ & & $\mathrm{X}$ & & $\mathrm{X}$ & & & & & & 27 \\
\hline Manganês & & $\mathrm{x}$ & & & & $\mathrm{X}$ & $\mathrm{X}$ & $\mathrm{X}$ & $\mathrm{X}$ & $\mathrm{X}$ & & 55 \\
\hline Alumínio & & & & & & $\mathrm{X}$ & $\mathrm{X}$ & & & & & 18 \\
\hline Coliformes fecais & & & & $\mathrm{X}$ & & $\mathrm{X}$ & $\mathrm{X}$ & $\mathrm{X}$ & & & & 36 \\
\hline $\begin{array}{l}\text { \% de parâmetros } \\
\text { analisados pelas } \\
\text { ETA }\end{array}$ & 23 & 54 & 23 & 54 & 23 & 100 & 77 & 77 & 38 & 38 & 38 & \\
\hline
\end{tabular}

De acordo com levantamento executado durante visitas às ETA notou-se que $27 \%$ das ETA realizam análises bacteriológicas da água bruta diariamente (ETA F, G e H), $18 \%$ as fazem semanalmente (ETA D e L), $9 \%$ analisam quinzenalmente (ETA E) e o restante (ETA A, B, C, I e J) não fazem estas análises (46\%).

Pode-se notar o aparecimento de florescimento de algas nas ETA A, F e G. Tal fenômeno pode ser decorrente do represamento à montante das captações devido a existência de barragens e do excesso de nutrientes encontrados nas águas de forma que as algas possuam condições favoráveis para seu desenvolvimento.

Alguns parâmetros físico-químicos tais como turbidez, cor e $\mathrm{pH}$ devem ser utilizados pelo gerente de ETA para determinar o tipo de coagulante, o pH ótimo de coagulação e a dosagem ótima de coagulante, assim como a viabilidade do emprego de auxiliares de coagulação através de ensaios utilizando reatores estáticos ("jar test"). Com os exames bacteriológicos da água bruta pode-se verificar se o corpo d'água está sofrendo contaminação por patogênicos.

Conforme pode ser observado na Tabela 7 e na Figura 13, somente 18\% (ETA F e H) das ETA visitas possuem algum programa de proteção dos mananciais, sendo que estes são ainda projetos sem existir no momento nenhum tipo de medida de preservação das características da água bruta.

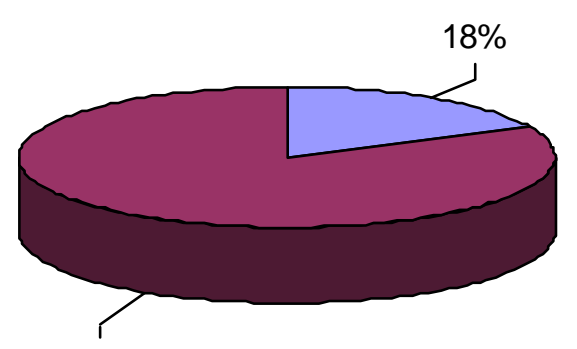


Figura 13: Porcentagem de estações de tratamento de água que possuem programa de proteção dos mananciais nas cidades visitadas

A seguir, apresentam-se fotografias mostrando algumas situações encontradas nos mananciais.

A Fotografia 1 mostra trabalhos de manutenção do canal de captação de água bruta da ETA C. A não realização de limpeza da caixa de areia pode ocasionar problemas de abrasão e desgaste da adutora. Na Fotografia 2 pode-se ver a captação de água da cidade $\mathrm{D}$ paralisada para a realização da dragagem do fundo do rio devido este se encontrar assoreado.

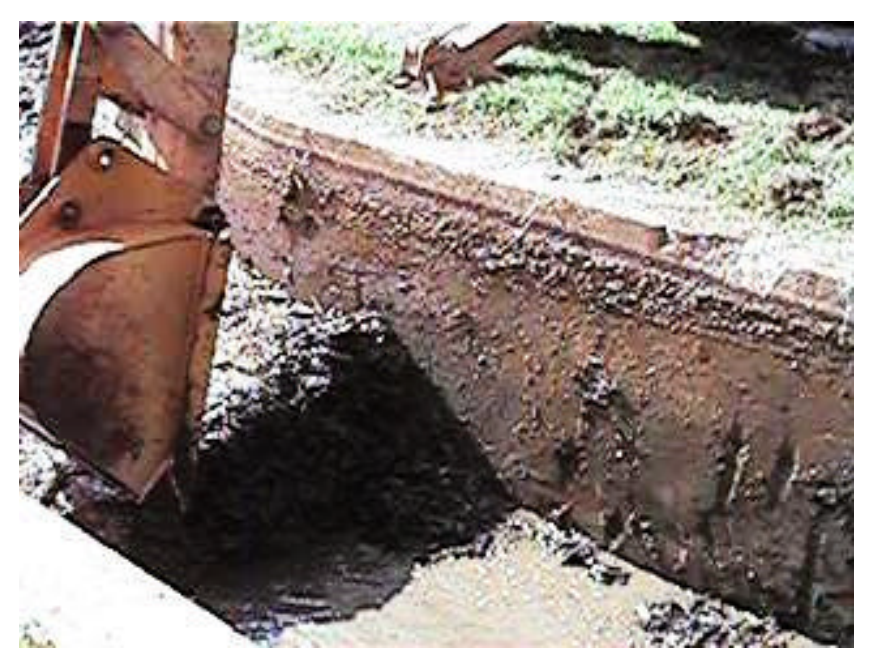

Fotografia 1: Limpeza do canal de captação da ETA C 


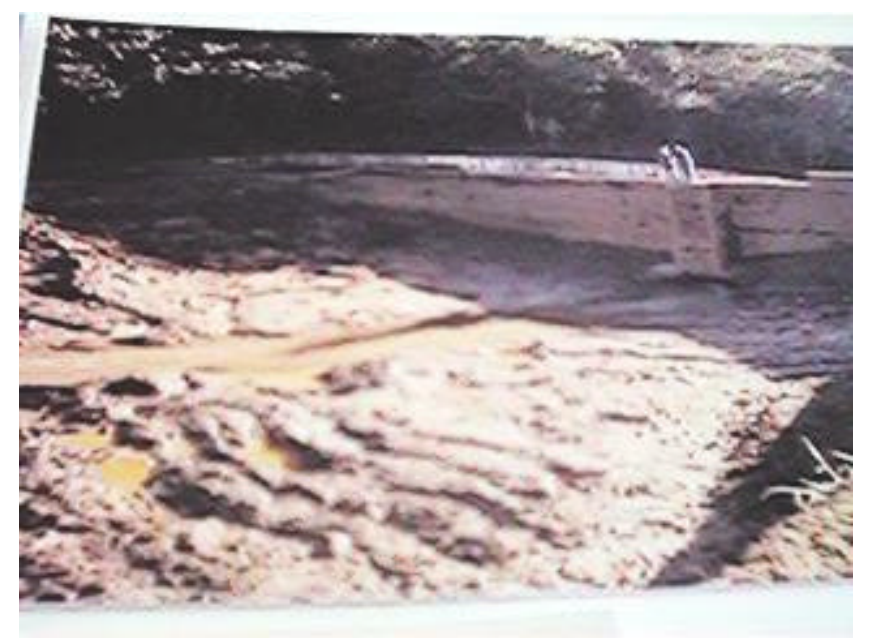

Fotografia 2: Manutenção da captação da ETA D

A Fotografia 3, mostra passagem de veículos em estrada que está sobre o manancial que dista da captação de água da ETA E, aproximadamente, $100 \mathrm{~m}$, sendo que esta estação abastece $50 \%$ da cidade e um eventual acidente como tombamento de veículo carregado com carga tóxica poderá acarretar sérios prejuízos à população.

A Fotografia 4 mostra o manancial a montante da captação (aproximadamente $10 \mathrm{~km}$ ) da ETA A com florescimento de algas, o que vem conferir sabor e odor, mesmo na água tratada.

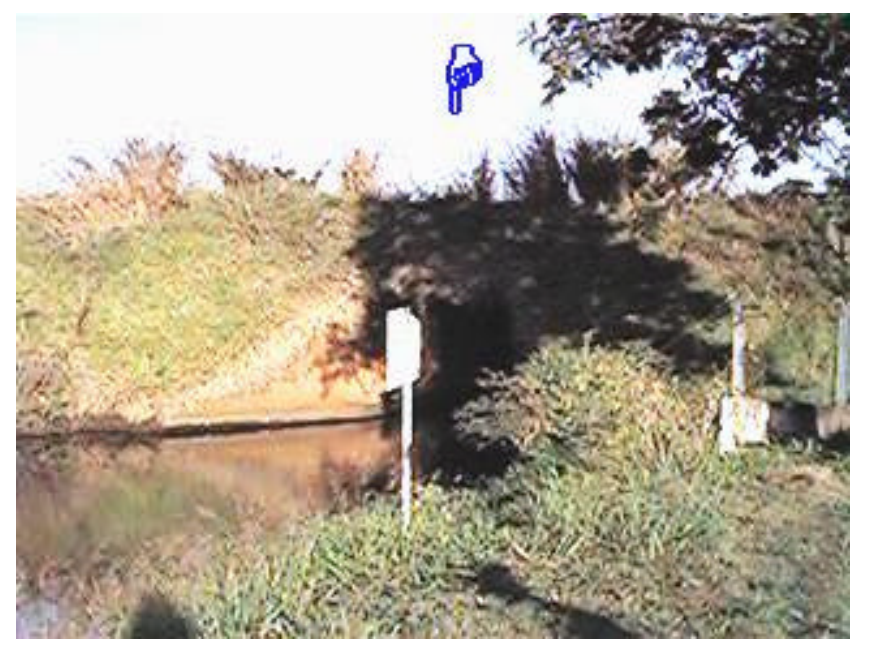

Fotografia 3:Rodovia passando em cima do rio de onde é captada água para a ETA E. 


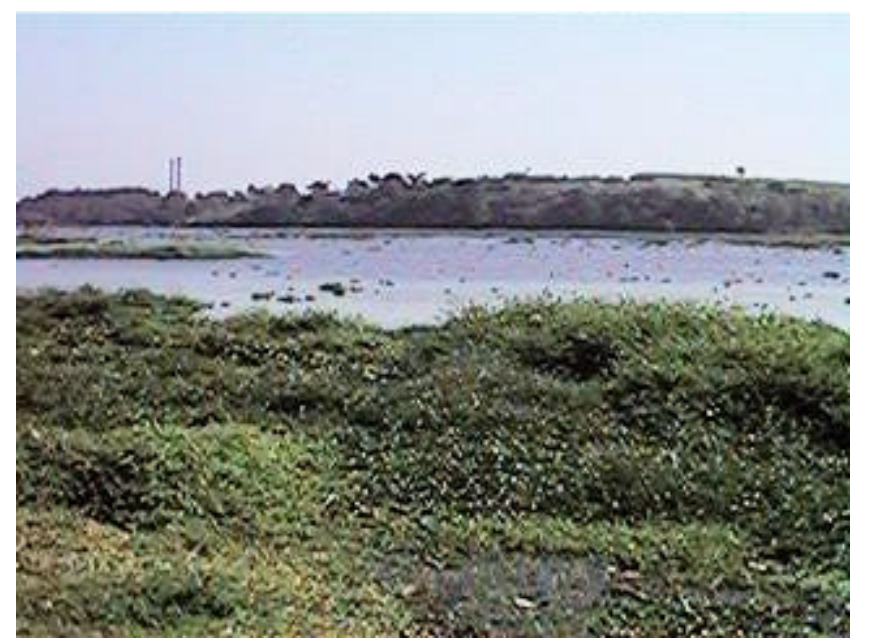

\section{Fotografia 4: Manancial que abastece a ETA A com floração de algas}

Florescimento de algas e assoreamento são alguns dos problemas frequientemente enfrentados em mananciais superficiais. Esses fatos concorrem para a degradação da qualidade da água bruta e conseqüiente aumento no consumo de coagulantes e auxiliares de coagulação. A existência de dados e acompanhamento da evolução dos mesmos no decorrer do tempo, torna-se elemento fundamental para o gerenciamento dos sistemas.

Através dos dados apresentados nota-se que o gerenciamento dos mananciais poderia ser mais elaborado, pois percebe-se que muitos dos sistemas não possuem dados ou os mesmos não são utilizados adequadamente. 


\subsection{Condições operacionais}

Em 73\% (8) das estações de tratamento de água visitadas verificou-se condições de trabalho com vazão igual ou maior que a de projeto (Tabela 10).

As estações que trabalham nessas condições (exceto para vazão igual à de projeto) correm o risco de produzir água com qualidade insatisfatória ou ter seu custo elevado para garantir a qualidade final do produto, pois o tempo de detenção hidráulica é reduzido.

Nesse caso há necessidade de aumento dos produtos químicos no tratamento da água, maior quantidade de água utilizada para lavagem de filtros, visto que os mesmos terão sua carreira de filtração reduzida, conseqüiente aumento no consumo energia elétrica para efetuar a operação.

Tabela 10: Vazão de projeto e vazão de operação das estações de tratamento de água visitadas.

\begin{tabular}{|c|c|c|c|}
\hline ETA & $\begin{array}{c}\text { Vazão de projeto } \\
(1 / \mathrm{s})\end{array}$ & $\begin{array}{c}\text { Vazão de operação } \\
(1 / \mathrm{s})\end{array}$ & $\begin{array}{c}\text { vazão de operação/ } \\
\text { vazão de projeto }\end{array}$ \\
\hline A & 850 & 850 & $\mathbf{1 , 0 0}$ \\
\hline B & 500 & 580 & $\mathbf{1 , 1 6}$ \\
\hline C & 220 & 220 & $\mathbf{1 , 0 0}$ \\
\hline D & 650 & 1000 & $\mathbf{1 , 5 4}$ \\
\hline E & 100 & 100 & $\mathbf{1 , 0 0}$ \\
\hline F & 1200 & 880 & 0,73 \\
\hline G & 700 & 850 & $\mathbf{1 , 2 1}$ \\
\hline H & 1500 & 1100 & 0,73 \\
\hline I & 400 & 500 & $\mathbf{1 , 2 5}$ \\
\hline J & 500 & 500 & $\mathbf{1 , 0 0}$ \\
\hline L & 500 & 400 & 0,80 \\
\hline
\end{tabular}




\subsubsection{Produtos químicos}

Nas ETA visitadas verificou-se que o parâmetro predominante na aquisição de produtos químicos em dez (91\%) empresas de abastecimento de água é o menor preço. Apenas uma das empresas visitadas compra o produto fazendo cotação de preço, porém também considera se a firma fornecedora possua certificado de qualidade expedida por órgão fiscalizador, antes de efetuar a compra (Tabela 11).

Tabela 11 : Aquisição, Controle de qualidade e Dosagem de Produtos Químicos.

\begin{tabular}{|c|c|c|c|}
\hline \multirow[b]{2}{*}{ ETA } & \multicolumn{3}{|c|}{ Produtos Químicos } \\
\hline & Aquisição & $\begin{array}{l}\text { Controle de } \\
\text { qualidade }\end{array}$ & Dosagem empregada na coagulação \\
\hline A & Menor preço & Não & Observação visual da floculação \\
\hline $\mathrm{B}$ & Menor preço & Sim & $\begin{array}{l}\text { Utilização de tabela elaborada no "jar-test", } \\
\text { relaciona vazão e turbidez e calcula a dosagem }\end{array}$ \\
\hline $\mathrm{C}$ & Menor preço & Não & Observação visual da floculação \\
\hline $\mathrm{D}$ & Menor preço & Sim & $\begin{array}{l}\text { Gráfico que relaciona turbidez e dosagem } \\
\text { elaborado com dados do "jar-test" }\end{array}$ \\
\hline$E$ & Menor preço & Não & $\begin{array}{l}\text { Visual, conforme observações e experiência do } \\
\text { operador }\end{array}$ \\
\hline $\mathrm{F}$ & $\begin{array}{l}\text { Preço e estar } \\
\text { credenciado a um } \\
\text { órgão fiscalizador }\end{array}$ & Sim & Ensaio em "jar-test" \\
\hline $\mathrm{G}$ & Menor preço & Sim & Ensaio em "jar-test" \\
\hline $\mathrm{H}$ & Menor preço & Sim & Ensaio em "jar-test" \\
\hline $\mathrm{I}$ & Menor preço & Não & $\begin{array}{l}\text { Utilização de tabela elaborada há alguns anos } \\
\text { atrás, porém não se sabe onde a mesma se } \\
\text { encontra }\end{array}$ \\
\hline $\mathrm{J}$ & Menor preço & Não & $\begin{array}{l}\text { Utilização de tabela elaborada há alguns anos } \\
\text { atrás, porém não se sabe onde a mesma se } \\
\text { encontra }\end{array}$ \\
\hline $\mathrm{L}$ & Menor preço. & Sim & $\begin{array}{l}\text { Utilização de tabela elaborada há alguns anos } \\
\text { atrás relacionando vazão, turbidez, cor e } \\
\text { dosagem }^{1}\end{array}$ \\
\hline
\end{tabular}

NOTAS:

1- Não são utilizados sistemas de controle de dosagem 
Depois de adquiridos, o controle de qualidade dos produtos químicos (Figura 14) é realizado por seis ETA visitadas (56\%). Contudo as mesmas não analisam todos os parâmetros especificados na licitação. As ETA que efetuam o controle de qualidade do produto químico são apresentadas na Tabela 11.

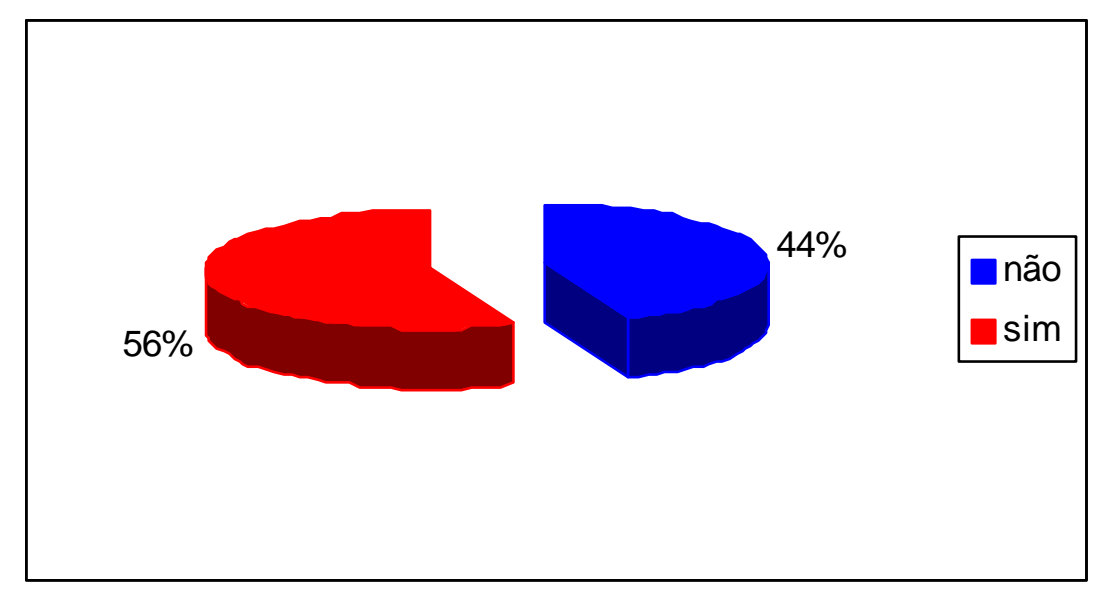

Figura 14 : Controle de Qualidade dos Produtos Químicos

O modo como os produtos químicos são manuseados e armazenados é muito importante devendo ser seguidas as especificações da NBR-592.

A Fotografia 5 registrou um descuido no armazenamento de cal, sendo este armazenado em área com presença de poças de água. Com exceção a esse fato, os produtos químicos das ETA visitadas encontravam-se devidamente acondicionados.

Na Fotografia 6, pode-se observar o ponto de aplicação do cloro e da cal com a finalidade de realizar a desinfecção e a correção de pH, respectivamente. Nessa fotografia percebe-se que os produtos químicos são aplicados no mesmo local. Tal situação foi encontrada nas ETA A e C por desconhecimento dos responsáveis (mesmo estes sendo engenheiros e químico respectivamente, conforme mostra a Tabela 20) quanto à obtenção de melhores resultados no tratamento se a desinfecção for realizada em valores baixos de $\mathrm{pH}$. Nas demais ETA, verificou-se que esses produtos são aplicados corretamente. 


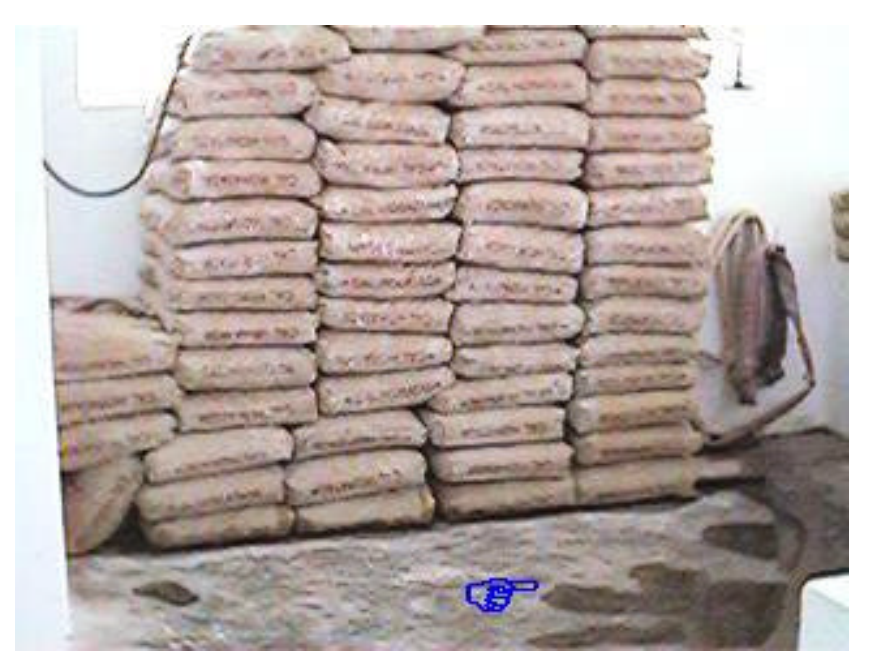

Fotografia 5: Armazenamento de cal da ETA B próximo à poças d'água

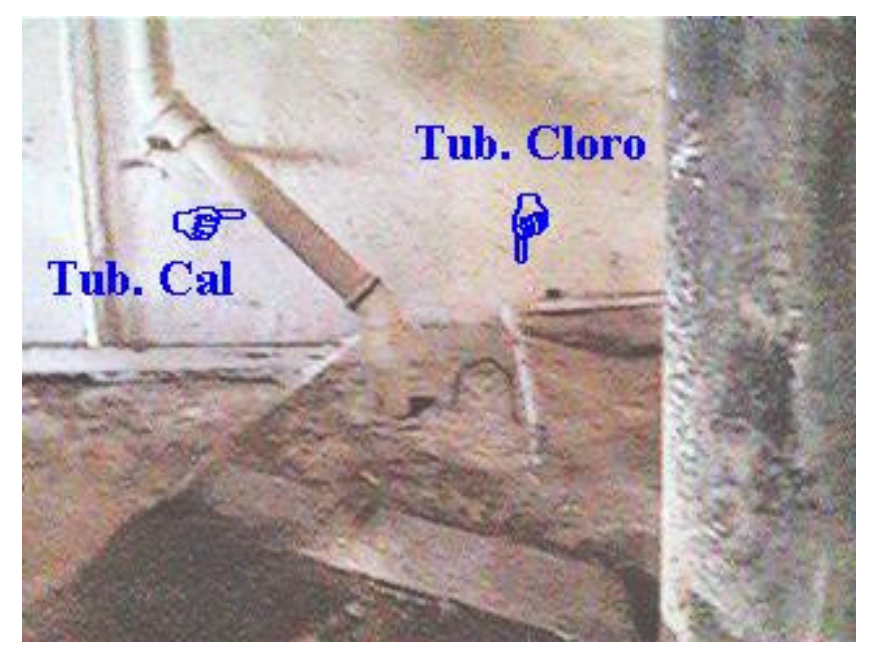

Fotografia 6: Desinfecção e correção de pH da ETA C

Analisando-se os requisitos especificados nos editais de licitação para aquisição de produtos químicos e tomando-se como base o modelo sugerido pela revista Saneamento e Municípios (Anexo A) percebe-se que algumas exigências não são seguidas pela maioria dos gerentes, conforme mostrado na Tabela 12. Deve ressaltar no entanto, que parcela dos gerentes não realiza nenhuma análise para verificação da qualidade do produto adquirido. Observou-se, ainda, que mesmo nas ETA onde esse controle é feito, as análises são feitas de modo incompleto, não varrendo todas as especificações definidas na licitação. 
Tabela 12: Especificação feita pelas ETA para aquisição do produto químico. Comparação com o modelo sugerido em Saneamento e Municípios (Dez 96/Jan 97).

\begin{tabular}{|c|c|}
\hline ETA & Especificações dos produtos químicos em relação ao artigo Saneamento e Municípios \\
\hline $\bar{A}$ & Não forneceu informações \\
\hline $\mathrm{B}$ & $\begin{array}{l}\text { No hipoclorito falta especificar hidróxidos. Acido fluossilícico falta especificar acidez devida a outros ácidos e metais } \\
\text { pesados. Cal atende as especificações. Cloreto férrico não consta no artigo. }\end{array}$ \\
\hline $\mathrm{C}$ & No sulfato de alumínio, na cal e no ácido fluossilícico faltam especificações \\
\hline $\mathrm{D}$ & Documentos de licitação ficam em São Paulo \\
\hline $\mathrm{E}$ & Especificações iguais as do artigo com exceção ao fluossilicato de sódio que não consta no artigo. \\
\hline $\mathrm{F}$ & Apresenta ausência de algumas especificações e um limite abaixo do estabelecido pelo artigo. \\
\hline $\mathrm{G}$ & Na cal não especifica o mínimo de óxido de cálcio e especifica hidróxido de magnésio e granulometria. \\
\hline $\mathrm{H}$ & $\begin{array}{l}\text { Demais produtos atende as especificações do artigo. Cloreto férrico e fluossilicato de sódio não constam no artigo. } \\
\text { Sulfato de alumínio atende ao artigo e tem várias especificações a mais de metais. }\end{array}$ \\
\hline I & Informação não adquirida \\
\hline $\mathrm{J}$ & Informação não adquirida \\
\hline $\mathrm{L}$ & $\begin{array}{l}\text { Na cal não é especificada óxido de cálcio e acrescenta material insolúvel e granulometria. } \\
\text { Os demais produtos atendem ao artigo, sendo que no sulfato de alumínio falta basicidade e acrescenta agentes } \\
\text { tensoativos e arsenito. }\end{array}$ \\
\hline
\end{tabular}

NOTA: 1. O artigo utilizado nesta análise encontra-se no Anexo A. Neste quadro fez-se a comprovação de algumas das exigências feitas na licitação. Não é realizado em nenhuma cidade um controle mais efetivo, por exemplo, se o produto químico possui algum metal que não deveria estar presente. 
A Tabela 25, no Anexo B apresenta os fornecedores de produtos químicos das estações visitadas para o tratamento de água no ano de 1996.

\subsubsection{Análise das etapas envolvidas no processo}

Várias empresas estão preocupadas em levantar o máximo possível de informações sobre a água, principalmente, sobre a água tratada, e estão perdendo informações importantes quando olham para os dados como um indicador momentâneo da qualidade de seu produto.

Para o funcionamento adequado do serviço, o acompanhamento dos dados deve ser realizado ao longo dos anos, o que permite verificar pontos no qual a empresa deve estar atenta. Estas informações dão condições para efetuar um programa de gerenciamento na empresa visando a obtenção de melhorias, pois sabese o que ocorreu em todo o sistema e quais ações precisam ser tomadas para atingir a meta estabelecida.

Nas visitas realizadas foi possível perceber que todas as ETA possuíam seus próprios laboratórios e a maioria realizava acompanhamento efetivo do processo, porém raramente os dados são usados para traçar diretrizes no processo de tratamento, servindo apenas para diagnóstico imediato da água..

$\mathrm{Na}$ operação das ETA pôde-se perceber que os problemas mais freqüentemente encontrados eram quebra de flocos na saída dos floculadores e na entrada do decantador e flotação no decantador (Tabela 13).

Através da Tabela 11 observa-se que somente cinco das onze estações de tratamento visitadas realizam a coagulação através de resultados obtidos em "jar test", sendo que as demais utilizam-se de conhecimento empírico. 
Os dados fornecidos pela Tabela 13 mostram que sete das ETA visitadas (64\%), fazem acompanhamento efetivo da água decantada, filtrada e distribuída.

As ETA I e J realizam análises da água decantada e distribuída com maior consistência do que com a água filtrada. Este caso preocupa, pois se a água produzida não estiver com qualidade satisfatória, só será percebido quando a mesma chegar às residências. O controle de qualidade da água das ETA C e E é realizado, somente para a água distribuída.

As condições em que se encontram armazenadas as informações das análises da água bruta, tratada e distribuída permite maior ou menor facilidade de acesso a estas. Esse fato foi verificado pela autora desta dissertação que teve bastante dificuldades neste aspecto, pois para um programa de gerenciamento não se faz necessário obter todas as análises horárias de um dia, mas sim que exista um relatório tal contendo informações resumidas, que permitam diagnosticar a situação do tratamento.

Na Tabela 13 encontra-se descrito a condição atual das ETA em estudo sobre a ótica organizacional, pois raras são as estações em que se encontram dados históricos do processo ou mesmo da água bruta.

Percebe-se na Tabela 13 que ocorre com frequiência flotação nos decantadores podendo este fato ser decorrente de falhas no projeto (em conseqüência da velocidade elevada na saída dos floculadores ou na entrada dos decantadores), dosagem imprópria ou a água bruta apresentando características tais que a operação de sedimentação possa ser dispensada. Estudos em laboratórios poderiam ser desenvolvidos com o intuito de verificar a viabilidade da implantação de outros equipamentos (por exemplo, flotadores), que nesse caso reduziria o consumo de produto químico empregado no tratamento.

A Tabela 14 relaciona os equipamentos existentes nos laboratórios físicoquímicos e bacteriológicos das estações visitadas. 
Tabela 14: Relação dos equipamentos existentes nos laboratórios das estações de tratamento de água visitadas

\begin{tabular}{|c|c|c|}
\hline \multirow{2}{*}{ ETA } & \multicolumn{2}{|c|}{ Equipamentos existentes } \\
\hline & Laboratório Físico-Químico & Laboratório Bacteriológico \\
\hline $\mathrm{A}$ & $\begin{array}{l}\text { Potenciômetro, turbidímetro, espectrofotómetro } \\
\text { DR 2000, banho-maria, potenciômetro, bureta }\end{array}$ & $\begin{array}{l}\text { Mufla, estufa (esterilização e } \\
\text { secagem). }\end{array}$ \\
\hline $\bar{B}$ & $\begin{array}{l}\text { Espectrofotómetro, turbidímetro, potenciômetro, } \\
\text { jar test, balança de precisão. capela de gases. }\end{array}$ & $\begin{array}{c}\text { Não possui laboratório } \\
\text { bacteriológico }\end{array}$ \\
\hline $\mathrm{C}$ & $\begin{array}{l}\text { potenciômetro, turbidímetro, balança de precisão, } \\
\text { indicador de cloro, espectrofotómetro DR 2000, } \\
\text { destilador, colorimeter DR } 100 .\end{array}$ & $\begin{array}{l}\text { Mufla, estufa (esterilização e } \\
\text { secagem), duas estufas de } \\
\text { cultura bacteriológica. }\end{array}$ \\
\hline $\mathrm{D}$ & $\begin{array}{l}\text { Turbidímetro, potenciômetro, dois turbidímetros } \\
\text { contínuo, medidor de cloro contínuo, medidor de } \\
\text { flúor contínuo, dois medidores de pH contínuo, } \\
\text { espectrofotómetro DR } 2000 \text {, fluorímetro. }\end{array}$ & $\begin{array}{l}\text { Espectrofotómetro DR 4000, } \\
\text { Mufla, estufa. }\end{array}$ \\
\hline $\mathrm{E}$ & $\begin{array}{l}\text { potenciômetro, turbidímetro, aquatest Helege, } \\
\text { fluorímetro, banho-maria, destilador, balança de } \\
\text { precisão. }\end{array}$ & $\begin{array}{l}\text { Não possui laboratório } \\
\text { bacteriológico }\end{array}$ \\
\hline $\mathrm{F}$ & $\begin{array}{l}\text { potenciômetro, balança de precisão, } \\
\text { espectrofotómetro DR 2000, banho-maria, } \\
\text { destilador, chapa para digestão, jar test, medidor } \\
\text { contínuo de turbidez. }\end{array}$ & $\begin{array}{l}\text { Estufa, incubadora, banho- } \\
\text { maria, microscópio, contador } \\
\text { de colônias, autoclave, estufa } \\
\text { de esterilização, bicos de } \\
\text { bunssem. }\end{array}$ \\
\hline $\mathrm{G}$ & $\begin{array}{l}\text { potenciômetro, turbidímetro, espectrofotómetro } \\
\text { DR 2000, condutivímetro, Hellige tester, medidor } \\
\text { de OD, bicos de bunssem, jar test, bureta. }\end{array}$ & Uitliza laboratório da ETA H \\
\hline$\overline{\mathrm{H}}$ & $\begin{array}{l}\text { potenciômetro, turbidímetro, espectrofotómetro } \\
\text { DR 2000, condutivímetro, bicos de bunssem, jar } \\
\text { test, bureta, colorímetro. }\end{array}$ & $\begin{array}{l}\text { Destilador, estufa de } \\
\text { esterilização, muflas, banho- } \\
\text { maria, estufa de secagem, } \\
\text { ducha preventiva à } \\
\text { contaminacãa. }\end{array}$ \\
\hline I & Turbidímetro, potenciômetro, fluorímetro & \\
\hline $\mathrm{J}$ & $\begin{array}{c}\text { Balanças de precisão, espectrofotómetro DR } \\
\text { 2000, potenciômetro. }\end{array}$ & $\begin{array}{l}\text { Autoclaves, banho-maria, } \\
\text { estufas de secagem. }\end{array}$ \\
\hline $\mathrm{L}$ & $\begin{array}{l}\text { Turbidímetro, potenciômetro, espectrofotómetro } \\
\text { DR 2000, colorímetro, banho-maria, digestor de } \\
\text { nitrogênio, capela de gases, deionizador, balança } \\
\text { de precisão }\end{array}$ & $\begin{array}{c}\text { Estufa de esterilização, } \\
\text { autoclave, banho-maria, } \\
\text { destilador de água, balança de } \\
\text { precisão. }\end{array}$ \\
\hline
\end{tabular}

De acordo com dados históricos apresentados pelas ETA e de acompanhamento das análises laboratoriais no decorrer das visitas, pode-se afirmar que a maioria das estações visitadas produzem água de acordo com o Padrão de Potabilidade estabelecido pela Portaria 36 G/M de 1990. Durante o período visitado somente a ETA A não apresentou qualidade satisfatória no que diz respeito à 
turbidez e cor, sendo constatados que estes parâmetros excediam os valores estabelecidos por esta Portaria.

\subsubsection{Limpeza do sistema de tratamento}

\subsubsection{1 Água de lavagem}

Na Tabela 15 apresentam-se as condições de controle da limpeza dos filtros e descargas de decantadores (descargas diárias e com remoção automática de lodo). Em 36\% (4) das ETA visitadas o controle é mais efetivo com acompanhamento de volume de água utilizado. Nas demais empregam-se estimativas. Esses dados são mostrados na

Figura 15.

Tabela 15: Controle de quantidade da utilizada na lavagem de filtros e dencantadores e descargas nos tanques de decantação

\begin{tabular}{|c|c|}
\hline ETA & Controle de quantidade de água utilizada para lavagens e descargas \\
\hline A & Não \\
\hline $\mathrm{B}$ & $\begin{array}{l}\text { Sim. Para os filtros mede-se o nível no reservatório x 1,2 / número de filtros } \\
\text { lavados no dia. Para água de descarga multiplica-se a vazão de entrada pelo } \\
\text { tempo de descarga e divide-se por } 2 \text {. }\end{array}$ \\
\hline $\mathrm{C}$ & Não \\
\hline $\mathrm{D}$ & $\begin{array}{l}\text { Não. Estima-se 3\% da vazão produzida, levando-se em conta volume dos } \\
\text { decantadores e dos filtros, bombas, tempo de lavagem }\end{array}$ \\
\hline $\mathrm{E}$ & $\begin{array}{l}\text { Não. Estima-se calculando a capacidade da bomba associada com o tempo gasto } \\
\text { para lavagem }\end{array}$ \\
\hline $\mathrm{F}$ & $\begin{array}{l}\text { Sim. Nos filtros é calculado através da vazão da bomba e o tempo gasto para } \\
\text { lavar. No decantador estima-se uma média a partir do volume do tanque. }\end{array}$ \\
\hline
\end{tabular}




\begin{tabular}{|c|c|}
\hline ETA & Controle de quantidade de água utilizada para lavagens e descargas \\
\hline $\mathrm{G}$ & Sim. Mede-se a diferença de nível do reservatório por meio de bóia de nível. \\
\hline $\mathrm{H}$ & Sim. Mede-se a diferença de nível do reservatório por meio de bóia de nível. \\
\hline $\mathrm{I}$ & $\begin{array}{l}\text { Não. Estima-se 5\% de água do volume tratado, considerando-se o volume do } \\
\text { reservatório de água para lavagem. }\end{array}$ \\
\hline $\mathrm{J}$ & $\begin{array}{l}\text { Não. Estima-se 5\% de água do volume tratado, considerando-se o volume do } \\
\text { reservatório de água para lavagem. }\end{array}$ \\
\hline $\mathrm{L}$ & $\begin{array}{l}\text { Não. Estima-se em } 5 \% \text { da vazão tratada de acordo com cálculo feito anos atrás } \\
\text { multiplicando vazão da bomba por tempo de lavagem. }\end{array}$ \\
\hline
\end{tabular}

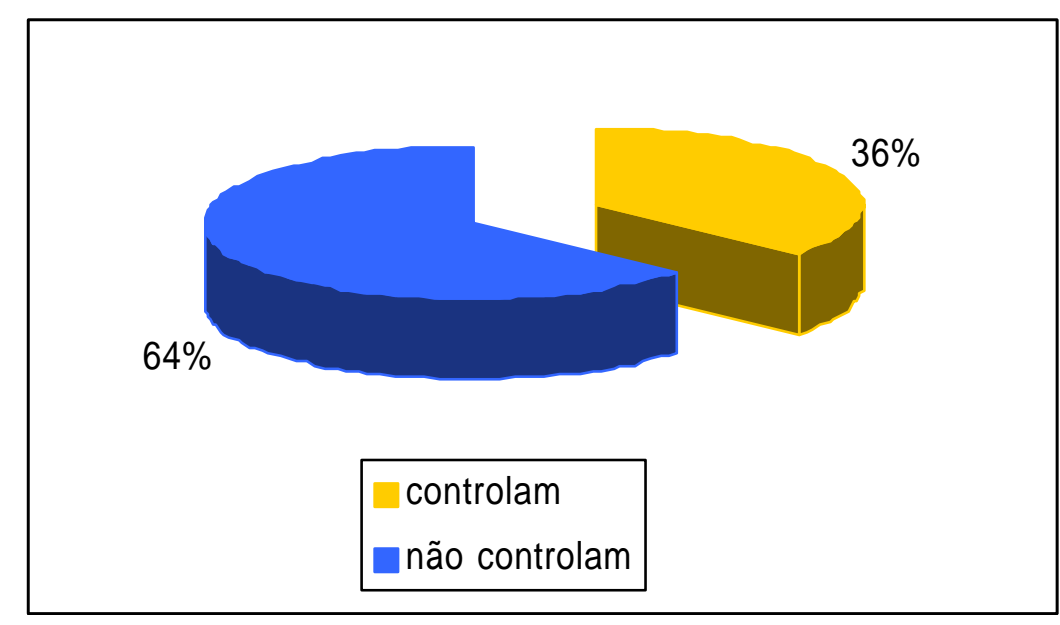

Figura 15: Controle da quantidade de água utilizada em lavagens e descargas

Através de dados da vazão aduzida e da vazão distribuída obtidos nas ETA G e $\mathrm{H}$, calculou-se o valor da perda de água dentro das ETA e obteve-se um valor igual a 5,7\% e 4,8\%, respectivamente, no ano de 1996 (valores mostrados na Tabela 17 e na Tabela 18). Nas demais ETA esta porcentagem é estimada pela própria gerência, pois não há dados registrados suficientes para obtenção deste resultado.

Tabela 17: Volume de água aduzida, volume de água utilizada na lavagem de filtros, volume de água descartado, volume de água distribuída e porcentagem de perda de água na ETA $G$ 


\begin{tabular}{|c|c|c|c|c|c|}
\hline ETA G & Volume de & $\begin{array}{c}\text { Volume de } \\
\text { água de }\end{array}$ & $\begin{array}{c}\text { Volume de } \\
\text { água }\end{array}$ & $\begin{array}{c}\text { Volume de } \\
\text { água }\end{array}$ & $\begin{array}{l}\text { \% de água } \\
\text { perdida na }\end{array}$ \\
\hline ANO & $\begin{array}{c}\text { água aduzida } \\
\qquad\left(\mathrm{m}^{3}\right)\end{array}$ & $\begin{array}{l}\text { lavagem de } \\
\text { filtros }\left(\mathrm{m}^{3}\right)\end{array}$ & $\begin{array}{c}\text { descartada } \\
\left(\mathrm{m}^{3}\right)\end{array}$ & $\begin{array}{c}\text { distribuída } \\
\left(\mathrm{m}^{3}\right)\end{array}$ & ETA \\
\hline 1992 & 18.699 .479 & 580.520 & 1.087 .725 & 17.031 .234 & 8,9 \\
\hline 1993 & 15.609 .400 & 488.800 & 1.082 .075 & 14.038 .525 & 10,0 \\
\hline 1994 & 16.624 .720 & 521.800 & 836.915 & 15.266 .005 & 8,2 \\
\hline 1995 & 17.691 .250 & 532.000 & 500.845 & 16.658 .405 & 5,8 \\
\hline 1996 & 18.321 .609 & 552.300 & 500.445 & 17.268 .864 & 5,7 \\
\hline
\end{tabular}

Observa-se pela Tabela 17 que a porcentagem de perdas de água na ETA G vem diminuindo nos últimos anos. Tal fato pode ser decorrente da implantação do programa de controle de perdas. Pela Tabela 18 percebe-se que o percentual de perdas na ETA $\mathrm{H}$ permaneceu praticamente igual no mesmo período.

Tabela 18: Volume de água aduzida, volume de água utilizada na lavagem de filtros, volume de água descartado, volume de água distribuída e porcentagem de perda de água na ETA $H$

\begin{tabular}{|c|c|c|c|c|c|}
\hline ETA H & Volume de & $\begin{array}{c}\text { Volume de } \\
\text { água de }\end{array}$ & $\begin{array}{c}\text { Volume de } \\
\text { água }\end{array}$ & $\begin{array}{c}\text { Volume de } \\
\text { água }\end{array}$ & $\begin{array}{l}\text { \% de água } \\
\text { perdida na }\end{array}$ \\
\hline ANO & $\begin{array}{c}\text { água aduzida } \\
\qquad\left(\mathrm{m}^{3}\right)\end{array}$ & $\begin{array}{l}\text { lavagem de } \\
\text { filtros }\left(\mathrm{m}^{3}\right)\end{array}$ & $\begin{array}{c}\text { descartada } \\
\left(\mathrm{m}^{3}\right)\end{array}$ & $\begin{array}{c}\text { distribuída } \\
\left(\mathrm{m}^{3}\right)\end{array}$ & ETA \\
\hline 1992 & 17.167 .550 & 317.275 & 473.340 & 16.376 .935 & 4,6 \\
\hline 1993 & 15.949 .220 & 464.440 & 482.795 & 15.001 .985 & 5,9 \\
\hline 1994 & 17.645 .725 & 511.885 & 463.885 & 16.669 .955 & 5,5 \\
\hline 1995 & 19.588 .740 & 376.324 & 744.734 & 18.467 .682 & 5,7 \\
\hline 1996 & 19.278 .280 & 286.660 & 640.945 & 18.350 .675 & 4,8 \\
\hline
\end{tabular}

A operação de lavagem dos filtros envolve questões relativas à quantidade de água utilizada, perdas operacionais, recuperação de água e possíveis impactos na descarga direta dos mesmos em cursos d'água. A visão integrada dessa operação pode gerar aspectos positivos nas ações citadas acima. Assim, economia de água na 
lavagem e a sua recuperação podem implicar em diminuição de perdas e minimização dos efeitos negativos no meio ambiente.

Os dados levantados revelaram que somente uma ETA recupera parte das águas de lavagem de filtros (64\%). O controle efetivo da quantidade de água utilizada na operação de lavagem destes não é efetuado pela maioria dos sistemas, concluindo-se que existe falha gerencial nesse ponto.

\subsubsection{Resíduos dos decantadores}

Como apresentado na Tabela 19 o período de permanência do lodo nos decantadores é de aproximadamente 2 meses. Em dez estações visitadas o destino final do rejeito proveniente dos tanques de sedimentação é o corpo d'água, sendo que somente uma destinava esse lodo corretamente em leito de secagem.

Com o tempo o lodo acumulado nos tanques tem sua concentração aumentada, tornando-se mais agressivo ao meio ambiente, o que poderá acarreta prejuízo ao corpo d'água.

Tabela 19: Frequiência de limpeza dos decantadores e destino dos rejeitos dos decantadores e filtros

\begin{tabular}{|c|l|l|}
\hline ETA & Freqüência de limpeza dos decantadores & \multicolumn{1}{|c|}{$\begin{array}{c}\text { Destino dos rejeitos } \\
\text { (decantadores e filtros) }\end{array}$} \\
\hline A & $\begin{array}{l}\text { Descarga semanal. Decantador lavado a } \\
\text { cada 2 meses. }\end{array}$ & Lançados em corpos d'água \\
\hline B & $\begin{array}{l}\text { 2 descargas por dia. Decantador lavado a } \\
\text { cada 2 meses }\end{array}$ & Lançados em corpos d'água \\
\hline C & Decantador lavado a cada 2 meses & Lançados em corpos d'água \\
\hline D & Decantador lavado a cada 2 meses & $\begin{array}{l}\text { Lançados em corpos d'água os } \\
\text { rejeitos dos decantadores e de 2 } \\
\text { filtros, a água de lavagem } \\
\text { proveniente dos demais filtros } \\
\text { são reaproveitados no tratamento }\end{array}$ \\
\hline E & Decantador lavado com 50 dias & Lançados em corpos d'água . \\
\hline F & Decantador lavado a cada 20 dias. & Lançados em corpos d'água \\
\hline G & $\begin{array}{l}\text { Descargas diárias. Lavagem dos } \\
\text { decantadores a cada 30 dias. }\end{array}$ & Lançados em corpos d'água \\
\hline
\end{tabular}




\begin{tabular}{|c|l|l|}
\hline H & $\begin{array}{l}\text { Decantador com raspador de lodo- 3 } \\
\text { descargas diárias e lavado a cada 7 } \\
\text { meses. } \\
\text { Decantador sem raspador de lodo lavado } \\
\text { a cada 50 dias. }\end{array}$ & Lançados em corpos d'água \\
\hline I & Decantador lavado a cada 2 meses. & Lançados em corpos d'água \\
\hline J & Decantador lavado a cada 2 meses. & Lançados em leitos de secagem \\
\hline L & Decantador lavado a cada 2 meses. & Lançados em corpos d'água \\
\hline
\end{tabular}




\subsubsection{Observações realizadas nas visitas}

Da Fotografia 7 à Fotografia 12 apresentam-se vazamentos de água nas bombas de recalque dos filtros e na galeria de saída dos mesmos.

Pequenos vazamentos nas bombas são necessários para lubrificação de gaxeta, no entanto os vazamentos mostrados nas fotografias a água vertia com frequiência, indicando pouca manutenção nas mesmas.

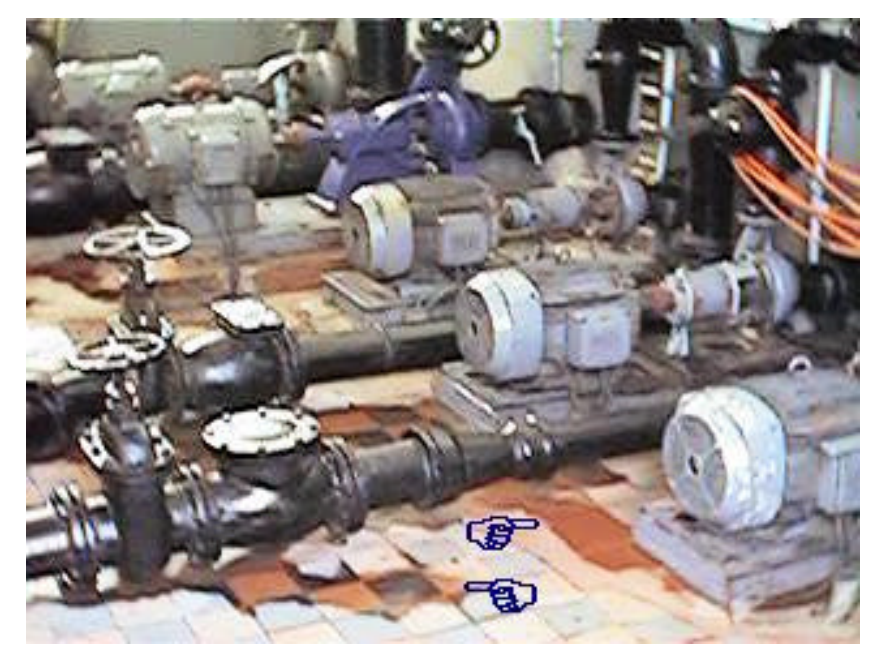

Fotografia 7: Vazamento nas bombas da ETA A

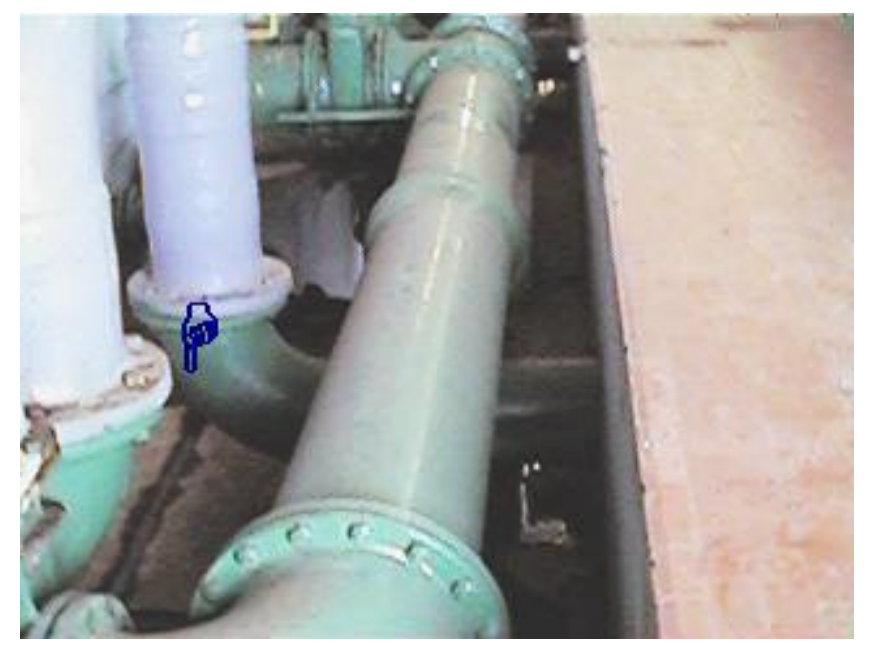

Fotografia 8: Vazamento na galeria dos filtros da ETA A 


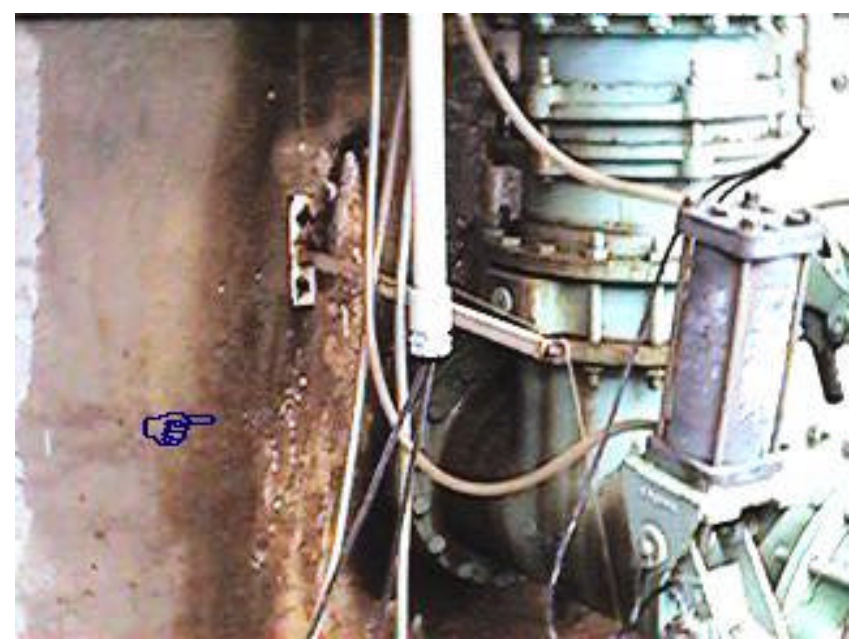

Fotografia 9: Vazamento no filtro da ETA D

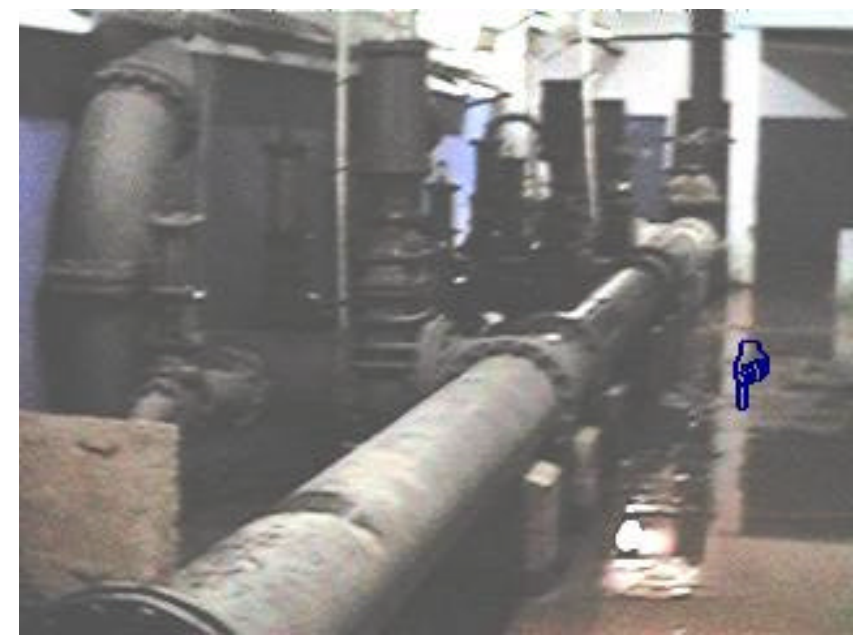

Fotografia 10: Vazamento na galeria de filtros da ETA I 


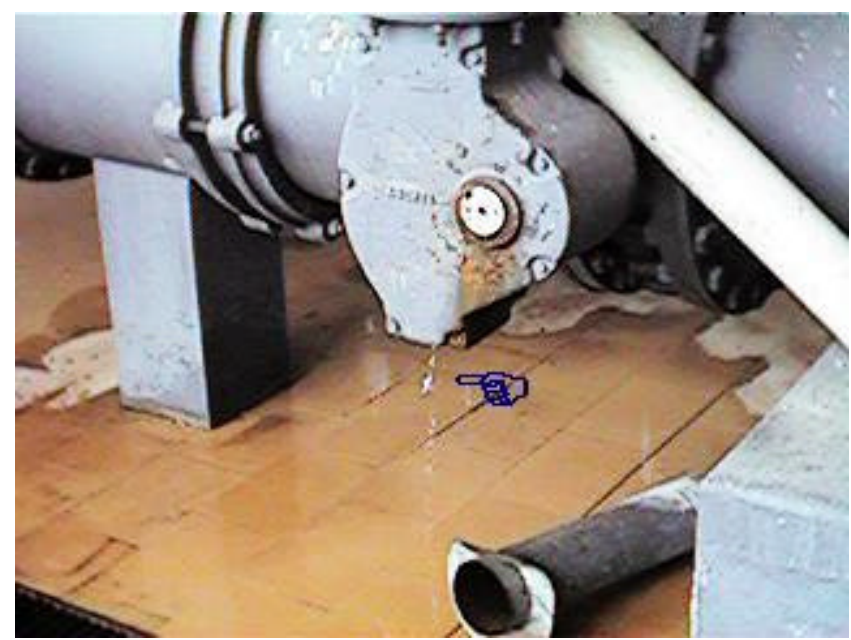

Fotografia 11: Vazamento na galeria de filtros da ETA J

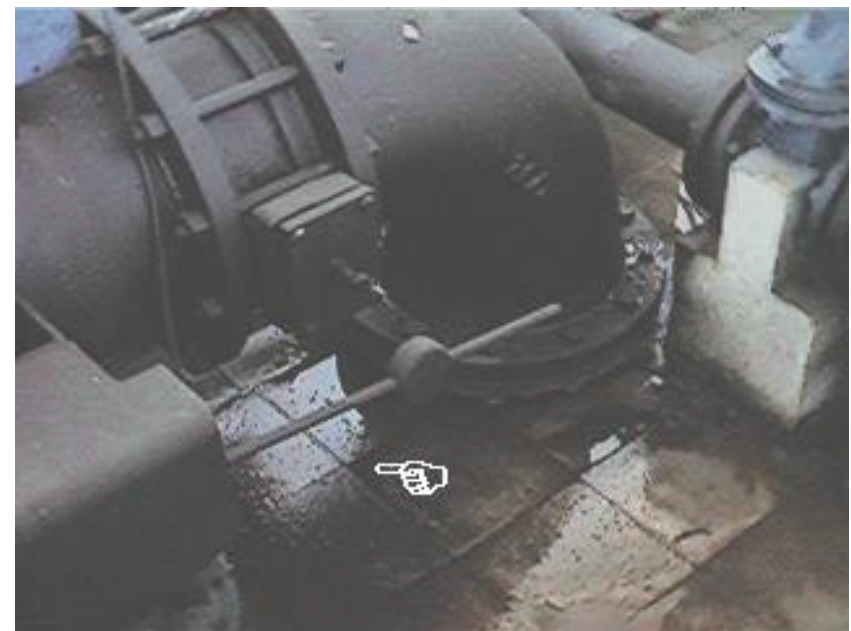

Fotografia 12: Vazamento na galeria de filtros da ETA L 
As Fotografias 13 e 14 mostram o problema de infiltração nas ETA, ocorrência freqüentemente encontrada.

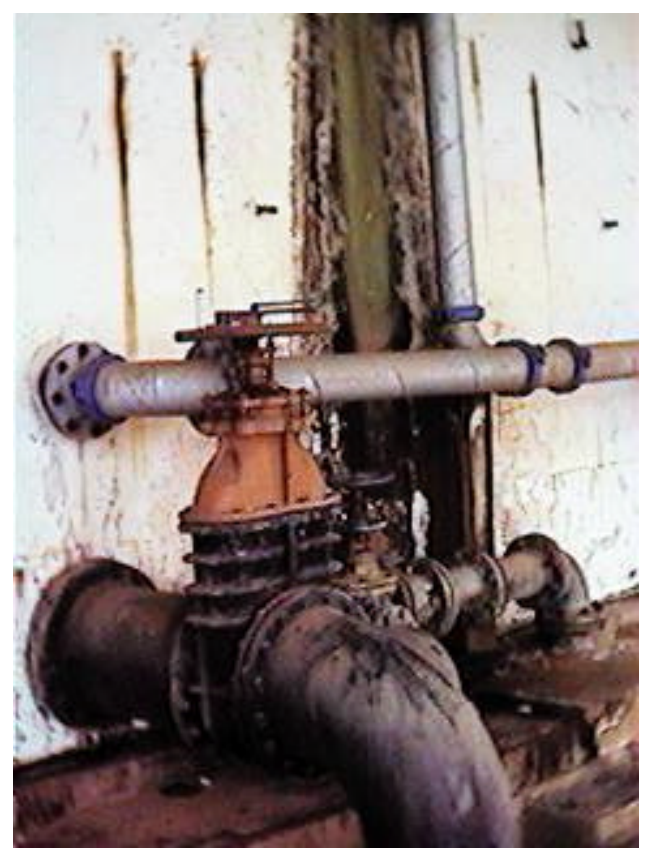

Fotografia 13: Infiltração na parede do filtro da ETA C

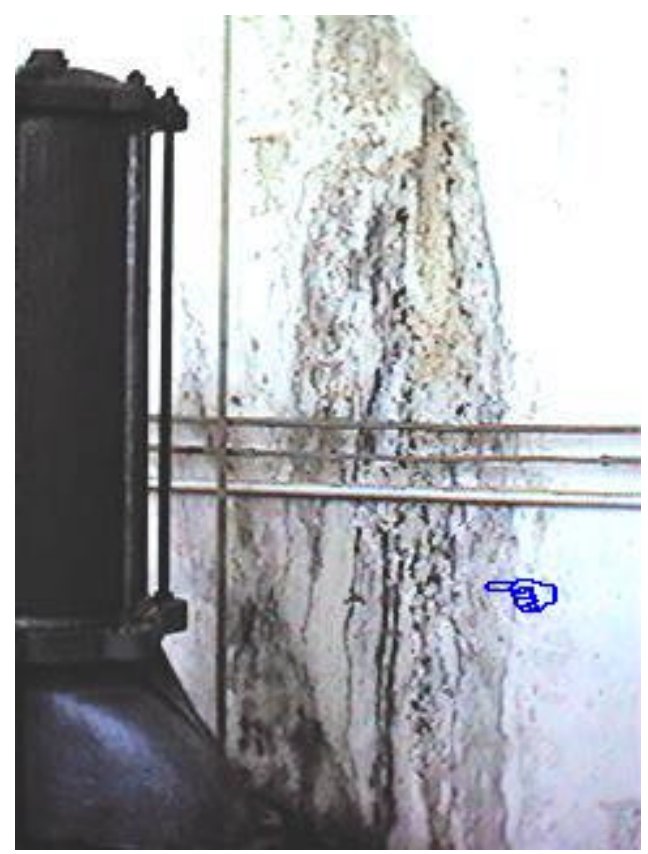

Fotografia 14: Infiltração na parede filtro na ETA 
Notou-se com grande freqüência que as ETA que utilizam meio filtrante composto por antracito e areia apresentam perda do material filtrante durante as lavagens dos filtros.

A Fotografia 15 mostra antracito (material filtrante) na galeria dos filtros, o que comprova a perda de material do meio filtrante durante a lavagem dos mesmos.

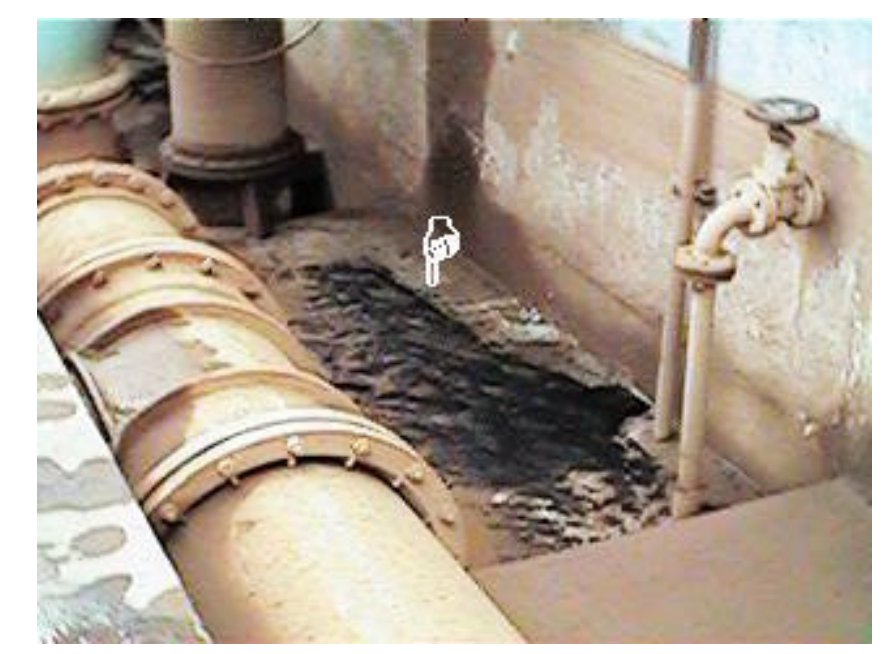

Fotografia 15: Perda de material filtrante na ETA D

O decantador mostrado na Fotografia 16 encontra-se com problema de flotação dos flocos formados nas câmaras de floculação, os quais deveriam estar sedimentando.

A Fotografia 17 mostra a lavagem manual do decantador, na qual a proteção utilizada pelo operador são botas de cano longo. Nesses tanques são armazenados lodos com características agressivas devido a introdução de produtos químicos no tratamento da água e do tempo de contenção deste material (aproximadamente 2 meses). 


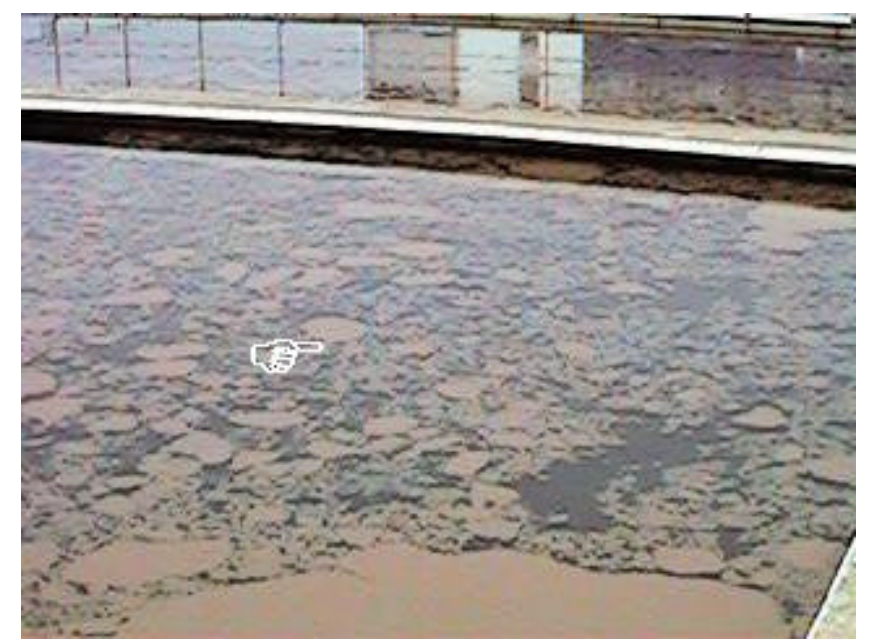

Fotografia 16: Decantador da ETA F - Ocorrência de flotação

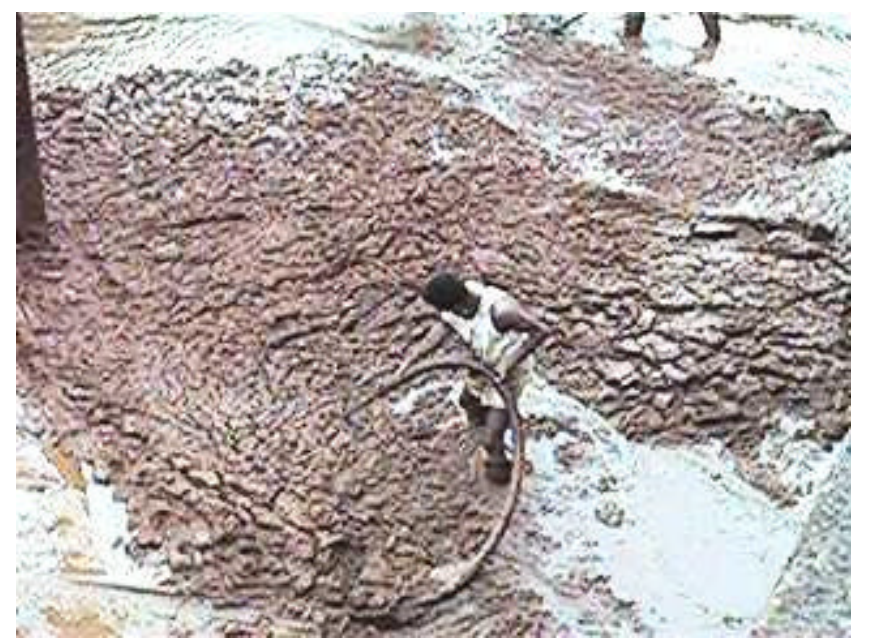

Fotografia 17: Lavagem do decantador da ETA I

As ETA $\mathrm{G}$ e $\mathrm{H}$ (Fotografia 18) indicam o adequado acompanhamento do funcionamento dos filtros através da utilização de mangueiras que marcam os níveis de perda de carga dos filtros, indicando qual o filtro com menor taxa de filtração, ou seja, qual o próximo a ser lavado. Simultaneamente a este controle de perda de carga também é feito um acompanhamento da turbidez da água que está saindo de cada filtro. O filtro será lavado se a turbidez atingir $1 \mathrm{uT}$ ou quando o nível de água do canal de entrada aos filtros (Fotografia 19) marcar 3,0 m. 


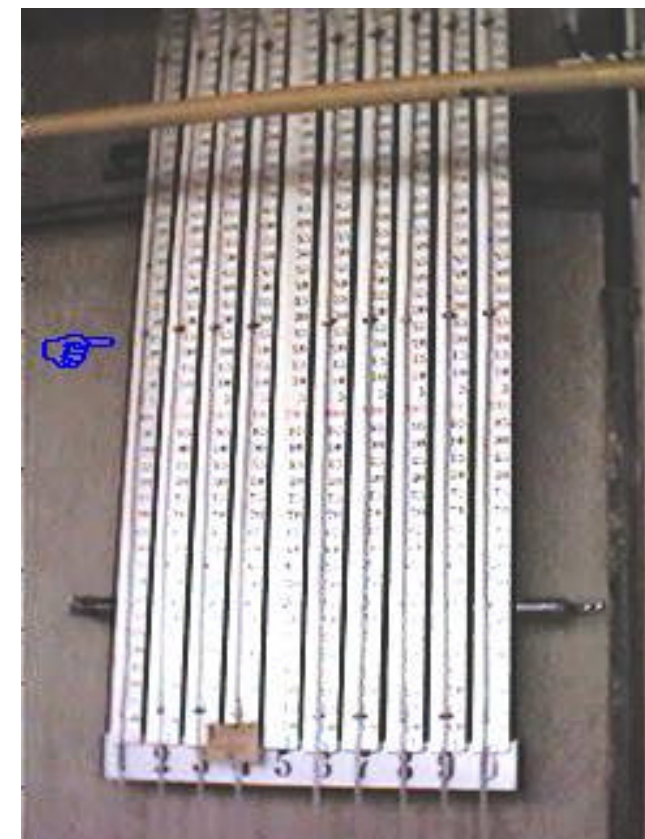

Fotografia 18: Piezômetros dos filtros das ETA G e H

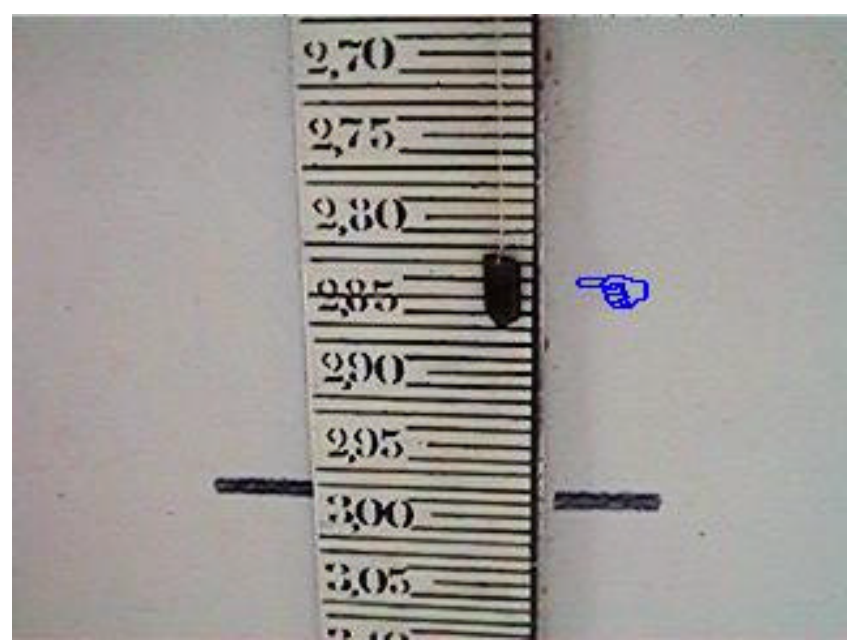

Fotografia 19: Controle do nível do canal de entrada aos filtros da ETA G 
A Fotografia 20 mostra uma câmara de floculação com acúmulo de flocos devido os decantadores estarem sobrecarregados em decorrência da ETA não ter concluído os leitos de secagem onde os rejeitos serão lançados. Nesta ETA o órgão de fiscalização (CETESB) estava alerta a qualquer alteração que o rio apresentasse, por isso os decantadores trabalhavam neste estado.

A realização de lavagem manual de um filtro pode ser vista na Fotografia 21.

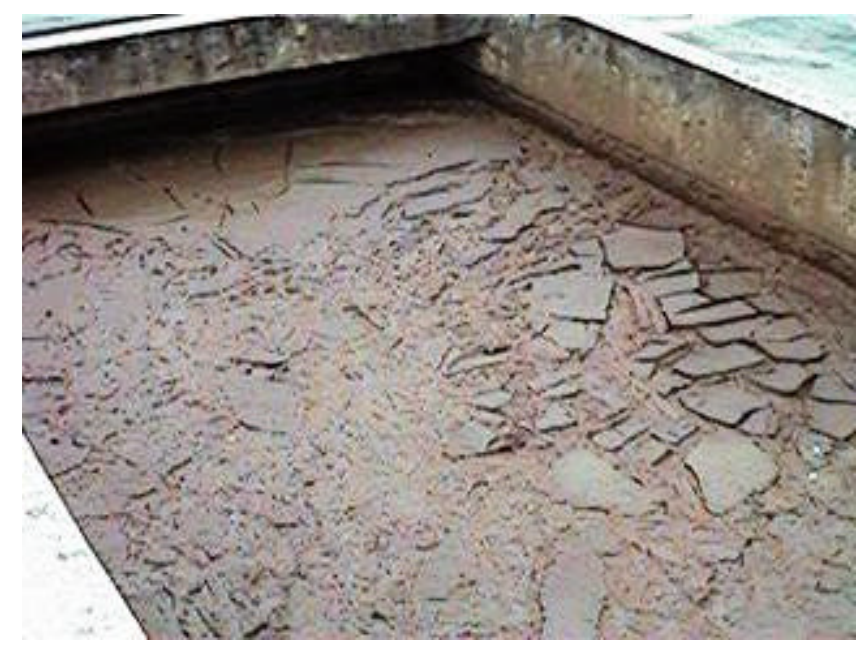

Fotografia 20: Floculador sobrecarregado da ETA J

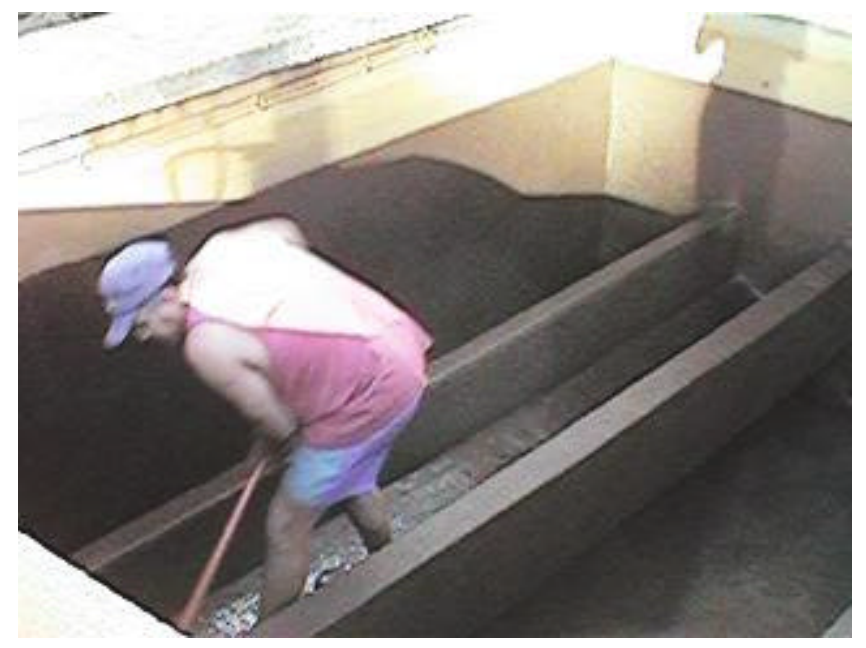

Fotografia 21: Lavagem filtro da ETA E 
Nas Fotografias 22 e 23, visualiza-se, respectivamente, a lateral do canal de água floculada e o reservatório com rachaduras. A ausência de manutenção da estrutura desta ETA ocasionou sérios prejuízos ao abastecimento de água da cidade. Com visão gerencial moderna dificilmente esta situação aconteceria porque o custo envolvido na recuperação de obras desse tipo é maior que o da manutenção, isso sem contar o custo devido a provável interrupção do abastecimento e os danos causados à qualidade da água tratada quando a rede de distribuição permanece por algum tempo sem funcionar.

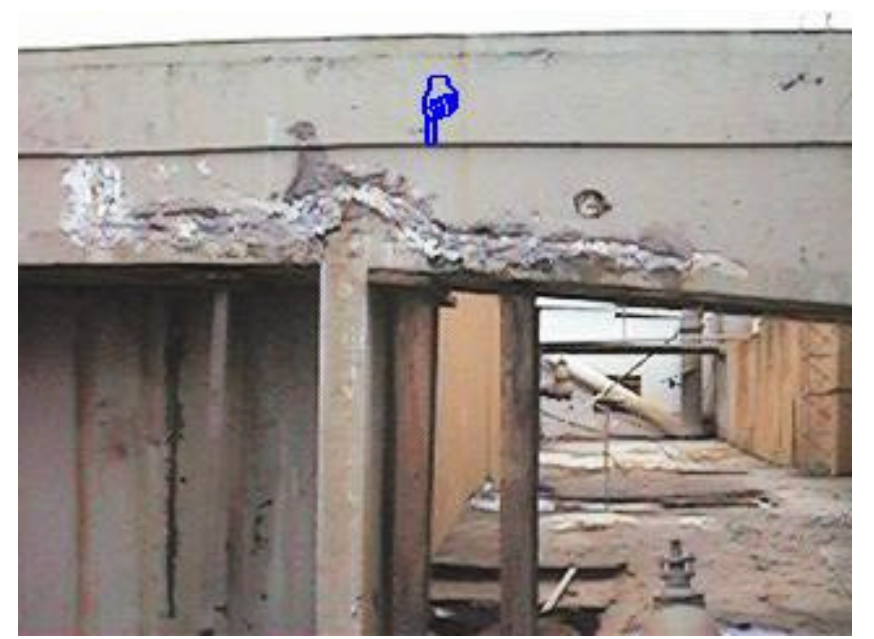

\section{Fotografia 22: Trinca canal de água floculada da ETA I}

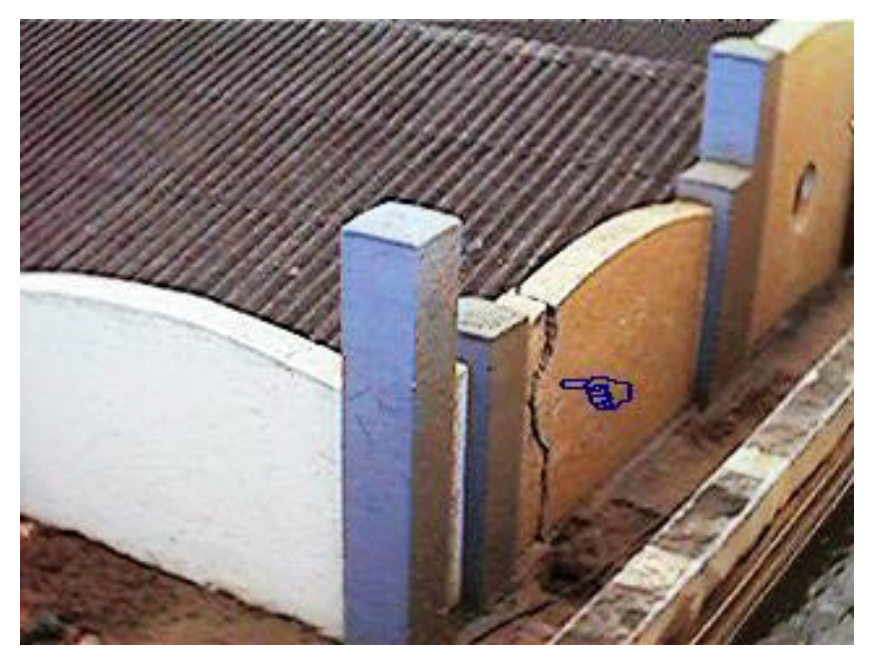

Fotografia 23: Trinca reservatório da ETA. 


\subsection{Grau de instrução dos recursos humanos}

Os dados levantados quanto ao grau de escolaridade dos operadores de ETA mostraram que $4 \%$ da totalidade dos operadores avaliados possuíam $3^{\circ}$ grau, $20 \%$ destes possuíam nível técnico, $16 \%$ o $2^{\circ}$ grau completo, $29 \%$ o $1^{\circ}$ grau completo e os $31 \%$ restante possuíam o $1^{\circ}$ grau incompleto, conforme mostra a Figura 17.

Os operadores mencionados referem-se àquelas pessoas que fazem a coleta $\mathrm{e}$ as análises de rotina (turbidez, cor aparente e $\mathrm{pH}$ ) da água bruta, decantada e filtrada e realizam o controle das dosagens de produtos químicos.

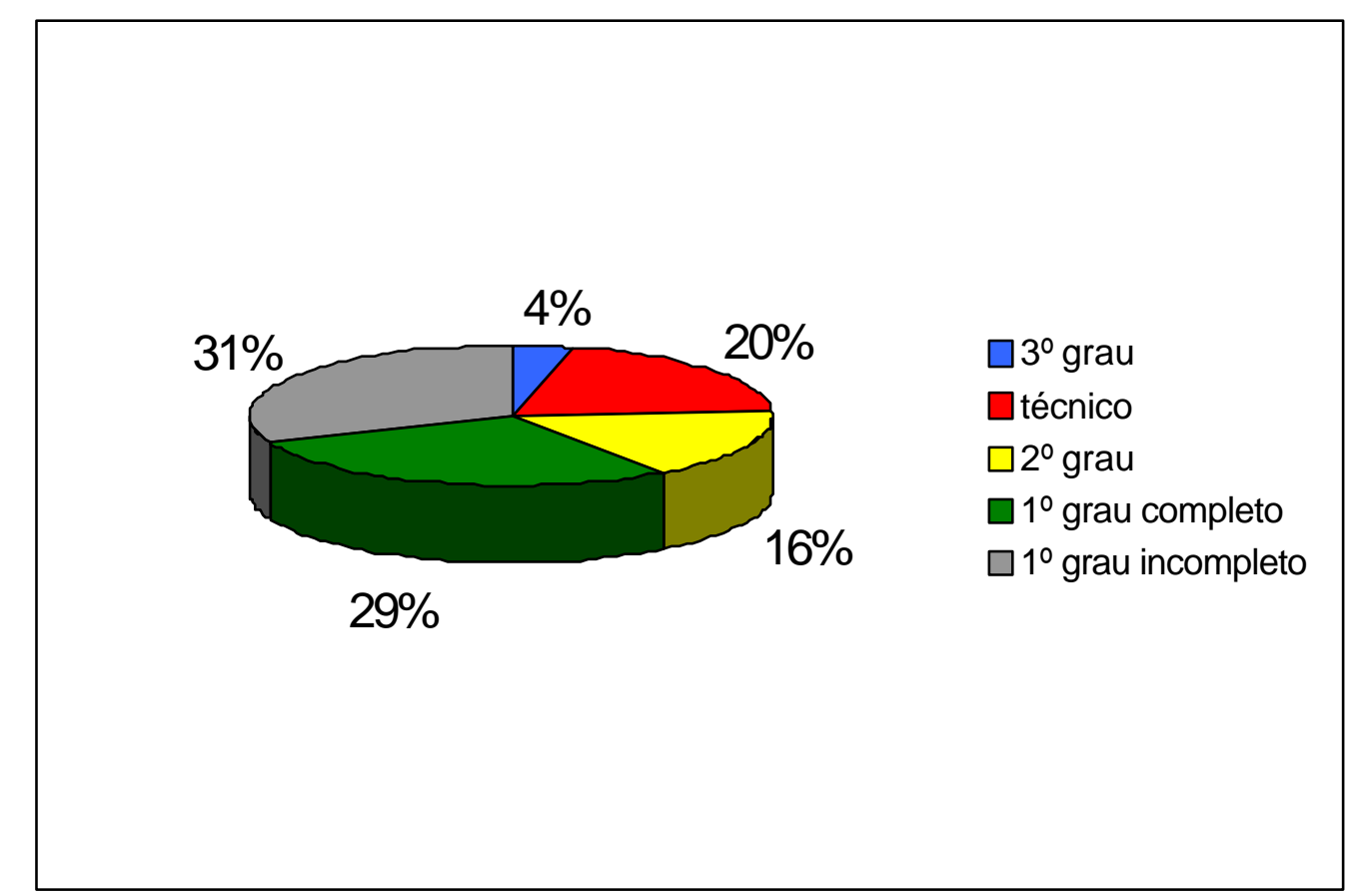

Figura 17: Nível de escolaridade dos operadores das ETA estudadas em relação ao número total destes funcionários

Na Figura 15, pode-se verificar que mais da metade dos operadores das ETA em estudo apresentam baixo grau de escolaridade, muitas vezes dificultando o aprendizado do processo de tratamento da água para abastecimento e outras não conseguindo perceber o tamanho de sua responsabilidade diante da operação. Embora espera-se mais do funcionário com maior escolaridade, ocorrem fatos que levantam questões tais como: Como está a qualidade do ensino? O programa estabelecido para os cursos atende as necessidades? Qual a relação existente entre 
responsabilidade e nível de escolaridade? Deveriam existir cursos específicos para operadores de ETA? entre outras.

No trabalho desenvolvido tais dúvidas surgiram em virtude da visita realizada em uma das ETA na qual, o operador mesmo possuindo nível superior não desempenhava sua função corretamente. Na maioria das vezes ele deixava a lavagem dos filtros para o operador do próximo turno. Das poucas vezes que realizava essa operação, os filtros tinham suas carreiras diminuídas. Neste caso, o nível de escolaridade é incompatível com o nível de responsabilidade.

A Tabela 19 mostra o grau de instrução dos operadores para cada uma das ETA estudadas. Os valores expressos em porcentagem referem-se à porcentagem destes funcionários em cada estação.

Tabela 20: Grau de instrução dos operadores de estação de tratamento de água.

\begin{tabular}{|c|c|}
\hline ETA & Recursos Humanos - Operadores \\
\hline $\bar{A}$ & $\begin{array}{l}60,0 \% \text { - técnico } \\
40,0 \%-1^{\circ} \text { grau incompleto }\end{array}$ \\
\hline B & $\begin{array}{l}60,0 \%-2^{\circ} \text { grau completo } \\
40,0 \% \text { - nível superior }\end{array}$ \\
\hline $\mathbf{C}$ & $100 \%-1^{\circ}$ grau incompleto \\
\hline D & $\begin{array}{l}80,0 \% \text { - técnico químico } \\
20,0 \%-1^{\circ} \text { grau incompleto }\end{array}$ \\
\hline $\bar{E}$ & 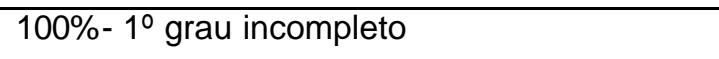 \\
\hline $\mathbf{F}$ & 100,0\%- tecnólogo \\
\hline $\mathbf{G}$ & $\begin{array}{l}40,0 \%-2^{\circ} \text { grau completo } \\
60,0 \% \text { - inferior ao } 2^{\circ} \text { grau }\end{array}$ \\
\hline $\mathbf{H}$ & $\begin{array}{l}56,0 \% \text { - } 1^{\circ} \text { grau incompleto } \\
11,0 \%-1^{\circ} \text { grau completo } \\
33,0 \%-2^{\circ} \text { grau completo }\end{array}$ \\
\hline I & $100 \%$ - máximo 1ํo grau completo \\
\hline $\mathbf{J}$ & $100 \%$ - máximo 1ํgrau completo \\
\hline $\mathbf{L}$ & $\begin{array}{l}50,0 \%-1^{\circ} \text { grau completo } \\
50,0 \%-1^{\circ} \text { grau incompleto }\end{array}$ \\
\hline
\end{tabular}


São apresentados na Tabela 20 os dados referentes ao grau de escolaridade dos responsáveis pelas estações de tratamento de água. Estes profissionais estão realizando, ou deveriam estar, a função de gerente da ETA.

Tabela 20: Grau de escolaridade dos responsáveis pelas Estações de tratamento de água.

\begin{tabular}{|c|c|c|c|c|c|c|c|}
\hline \multirow{3}{*}{$\begin{array}{c}\text { Faixa de } \\
\text { população } \\
\text { (hab.) }\end{array}$} & \multirow{3}{*}{ ETA } & \multicolumn{6}{|c|}{ Responsável pela ETA (gerente) } \\
\hline & & \multicolumn{6}{|c|}{ Formação } \\
\hline & & $\begin{array}{l}\text { Eng. } \\
\text { Civil }\end{array}$ & $\begin{array}{c}\text { Eng. } \\
\text { Químico }\end{array}$ & Químico & Biólogo & $\begin{array}{c}\text { Tecnólogo em } \\
\text { saneamento }\end{array}$ & Técnico \\
\hline$<100.000$ & $\mathrm{E}$ & & & & & & 1 \\
\hline \multirow{6}{*}{$\begin{array}{l}100.000 \mathrm{a} \\
200.000\end{array}$} & A & 1 & 1 & & & & \\
\hline & B & 1 & & & & & \\
\hline & $\mathrm{C}$ & & & 1 & & & \\
\hline & $\mathrm{I}$ & 1 & & & & & \\
\hline & $\mathrm{J}$ & & & & 1 & & \\
\hline & $\mathrm{L}$ & & & 1 & & & \\
\hline \multirow{4}{*}{$>200.000$} & D & & & 1 & & & \\
\hline & $\mathrm{F}$ & & 1 & & & & \\
\hline & $\mathrm{G}$ & 1 & & & & 1 & \\
\hline & $\overline{\mathrm{H}}$ & & & & & 2 & \\
\hline
\end{tabular}

Conforme mostrado na Tabela 20, o grau de escolaridade do responsável pela ETA encontrado na cidade com população inferior a 100.000 habitantes é relativamente baixo. Nas cidades com população entre 100.000 e 200.000 habitantes todos os funcionários possuem nível superior, sendo que o profissional que aparece com maior freqüência é o engenheiro civil. Para populações maiores que 200.000 habitantes nota-se que o grau de escolaridade dos responsáveis pelas ETA é de nível 
superior, sendo que em duas estações (ETA $\mathrm{G} \mathrm{e} \mathrm{H}$ ) encontrou-se profissionais com formação específica na área de saneamento (tecnólogo em saneamento).

A Tabela 21 mostra os dados referentes ao grau de escolaridade dos responsáveis pelos laboratórios das estações de tratamento de água visitadas. Estes profissionais são responsáveis pela qualidade da água tratada.

Tabela 22: Grau de escolaridade dos responsáveis pelos laboratórios das ETA visitadas.

\begin{tabular}{|c|c|c|c|c|c|c|}
\hline \multirow{3}{*}{$\begin{array}{c}\text { Faixa de } \\
\text { população } \\
\text { (hab.) }\end{array}$} & \multirow{3}{*}{ ETA } & \multicolumn{5}{|c|}{ Responsável pelo(s) laboratório(s) } \\
\hline & & \multicolumn{5}{|c|}{ Formação } \\
\hline & & Químico & Biólogo & $\begin{array}{c}\text { Tecnólogo em } \\
\text { saneamento }\end{array}$ & Técnico & $2^{\circ}$ grau \\
\hline$<100.000$ & $\mathrm{E}$ & 1 & & & & \\
\hline \multirow{6}{*}{$\begin{array}{l}100.000 \mathrm{a} \\
200.000\end{array}$} & A & & & & 2 & \\
\hline & B & 2 & & & & \\
\hline & $\mathrm{C}$ & & & & 2 & \\
\hline & $\mathrm{I}^{\mathrm{T}}$ & & & & \multirow[b]{2}{*}{2} & \\
\hline & $\mathrm{J}^{1}$ & & & & & \\
\hline & $\mathrm{L}$ & 1 & 2 & & 1 & \\
\hline \multirow{4}{*}{$>200.000$} & $\bar{D}$ & & & & 2 & \\
\hline & $\mathrm{F}$ & 1 & 1 & & & \\
\hline & $\mathrm{G}$ & & & & 1 & 1 \\
\hline & $\overline{\mathrm{H}}$ & 1 & & & 1 & 1 \\
\hline
\end{tabular}

NOTA: 1- As ETA I e J utilizam o mesmo laboratório.

Conforme apresentado na Tabela 21 todas as ETA possuem funcionários responsáveis por laboratório. Somente dois de vinte e dois funcionários não possuíam formação técnica ou nível superior. Dentro da ETA é o laboratório quem realiza o controle da qualidade do produto final. 
De modo geral o grau de escolaridade dos responsáveis pela ETA, bem como dos responsáveis pelos laboratórios, pode ser considerado satisfatório, com exceção encontrada ao cargo de responsável pela ETA na cidade com população inferior a 100 mil. Contudo deve-se lembrar que possuir nível de escolaridade elevada não é garantia do profissional estar preparado para desempenhar papel de gerente, pois para isso é necessário o aperfeiçoamento contínuo do mesmo.

\subsection{Consumo de produtos químicos e energia elétrica}

A Tabela 22 mostra o volume de água tratada em cada uma das ETA, o consumo de energia elétrica utilizado no tratamento e no recalque da água tratada e o consumo de produtos químicos (coagulante, cloro e cal) empregado para efetuar o tratamento da água. 
Tabela 23: Volume de água tratada, Consumo de energia elétrica, Consumo de produtos químicos no ano de 1996.

\begin{tabular}{|c|c|c|c|c|c|}
\hline \multirow{3}{*}{ ETA } & \multicolumn{5}{|c|}{ ETA } \\
\hline & \multirow{2}{*}{$\begin{array}{l}\text { Volume de água } \\
\text { tratada (mªno) }\end{array}$} & \multirow{2}{*}{$\begin{array}{l}\text { Consumo de energia elétrica } \\
\text { (kwh/ano) }\end{array}$} & \multicolumn{3}{|c|}{ Consumo de Produtos Químicos (kg/ano) } \\
\hline & & & Coagulante & cal & cloro \\
\hline A & $22.161 .600^{2}$ & Não foi fornecido & $614.692,8^{5}$ & $337.478^{5}$ & $354,9^{5}$ \\
\hline$B$ & 13.851 .773 & 3.906 .712 & 578.520 & 469.620 & 27.490 \\
\hline $\mathrm{C}$ & 6.699 .260 & 2.420 .800 & 147.500 & 109.120 & 16.064 \\
\hline $\mathrm{D}$ & 22.985 .640 & $1.469 .040^{4}$ & $1.421 .925+7.715$ (polieletrólito) & 389.400 & 78.300 \\
\hline$E$ & $2.689 .200^{2}$ & $933.120^{6,7}$ & 64.460 & 33.625 & 3.228 \\
\hline $\bar{F}$ & 23.625 .209 & 1.016 .600 & $325.005,88+248.230$ litros & 330.680 & $108.408+15.858,4$ \\
\hline $\mathrm{G}$ & 18.321 .609 & 675.905 & 1.999 .140 & 1.004 .790 & 170.306 \\
\hline $\mathrm{H}$ & 18.637 .335 & 463.178 & 1.720 .624 & 417.590 & 145.378 \\
\hline $\mathrm{I}$ & $11.601 .792^{4}$ & $2.966 .368^{3}$ & 686.570 & 230.300 & 46.538 \\
\hline $\mathrm{J}$ & $9.548 .928^{4}$ & $4.665 .428^{3}$ & 499.898 & 167.376 & 31.022 \\
\hline $\mathrm{L}$ & 13.094 .290 & 2.440 .316 & 205.500 & 148.338 & 23.467 \\
\hline
\end{tabular}

NOTAS: $\quad$ 1- a desinfecção na ETA F é realizada empregando cloro + sulfato de amônio.

2- valores estimados a partir da vazão de trabalho da ETA.

3- referente ao ano de 1997.

4- valor estimado em função da vazão média diária no ano de 1997.

5- consumo estimado à partir da dosagem média anual e da vazão tratada.

6- valor estimado pelo consumo médio de energia do ano de 1996.

7- consumo de energia é a somatória do consumo na captação, no tratamento e no recalque. Os demais referem-se a somatória do consumo no tratamento e no recalque. 
Com a finalidade de proporcionar melhor visualização do consumo de energia elétrica e de produtos químicos utilizados nas ETA, apresenta-se uma relação entre estes consumos e a volume de água tratada. Essa lista é apresentada ma Tabela 23. Os valores foram plotados e podem ser encontrados nas Figuras 16, 18,19 e 20. Esses dados permitem levantar algumas questões sobre as diversas ETA em estudo.

Tabela 24: Relação consumo de energia elétrica/volume de água tratada e consumo de produtos químicos/volume de água tratada

\begin{tabular}{|c|c|c|c|c|}
\hline ETA & $\begin{array}{c}\text { Consumo de energia } \\
\text { elétrica/volume de } \\
\text { água tratada } \\
\mathrm{kwh} / \mathrm{m}^{3}\end{array}$ & $\begin{array}{c}\text { Consumo de coagulante/ } \\
\text { volume de água tratada } \\
\mathrm{kg} / \mathrm{m}^{3}\end{array}$ & $\begin{array}{c}\text { Consumo de } \\
\text { cloro/volume de } \\
\text { água tratada } \\
\mathrm{kg} / \mathrm{m}^{3}\end{array}$ & $\begin{array}{c}\text { Consumo } \\
\text { cal/volume de } \\
\text { água tratada } \\
\mathrm{kg} / \mathrm{m}^{3}\end{array}$ \\
\hline A & & 0,0277 & $1,60 \mathrm{E}-05$ & 0,0152 \\
\hline B & 0,2820 & 0,0418 & $1,98 \mathrm{E}-03$ & 0,0339 \\
\hline C & 0,3614 & 0,0220 & $2,40 \mathrm{E}-03$ & 0,0163 \\
\hline D & 0,0639 & 0,0619 & $3,41 \mathrm{E}-03$ & 0,0169 \\
\hline E & 0,3470 & 0,0240 & $1,20 \mathrm{E}-03$ & 0,0125 \\
\hline F & 0,0430 & 0,0248 & $4,59 \mathrm{E}-03$ & 0,0140 \\
\hline G & 0,0369 & 0,1091 & $9,30 \mathrm{E}-03$ & 0,0548 \\
\hline H & 0,0249 & 0,0923 & $7,80 \mathrm{E}-03$ & 0,0224 \\
\hline I & 0,2557 & 0,0592 & $4,01 \mathrm{E}-03$ & 0,0199 \\
\hline J & 0,4886 & 0,0524 & $3,25 \mathrm{E}-03$ & 0,0175 \\
\hline L & 0,1864 & 0,0157 & $1,79 \mathrm{E}-03$ & 0,0113 \\
\hline
\end{tabular}

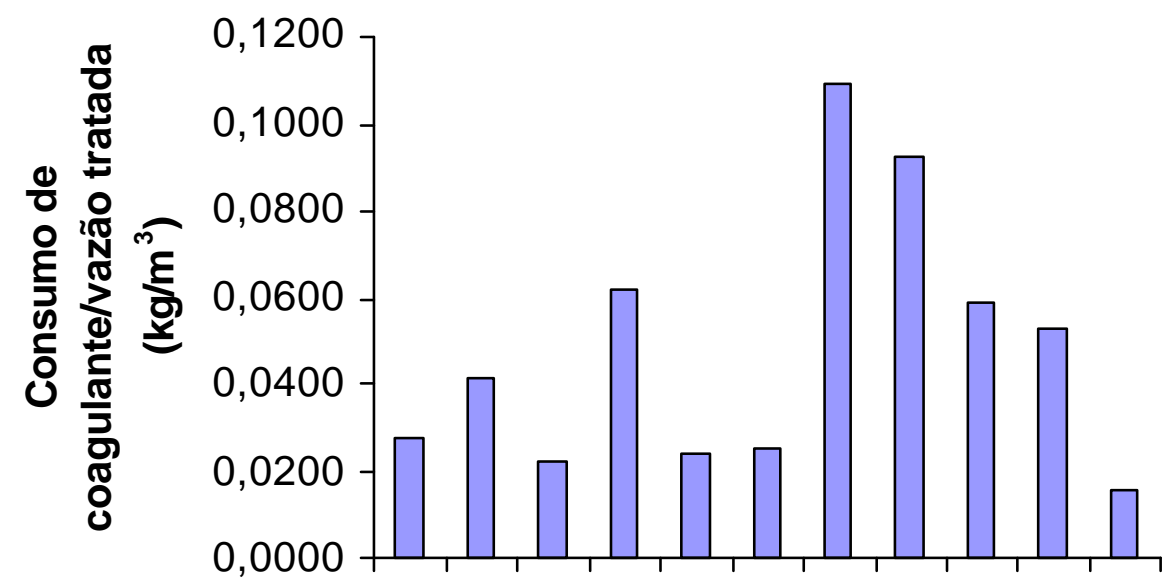

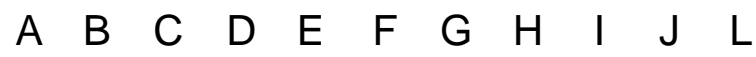

ETAs

Figura 18: Consumo de coagulante por volume de água tratada $\left(\mathrm{kg} / \mathrm{m}^{3}\right)$ 
A Figura 16 apresenta a razão entre o consumo de coagulante empregado no tratamento e volume de água produzida. Como a quantidade de coagulante empregada no tratamento depende da qualidade da água bruta, pode-se através deste gráfico comparar as ETA A com $\mathrm{G}$ e $\mathrm{H}$ com $\mathrm{J}$ por possuírem o mesmo manancial. Neste gráfico percebe-se que a ETA A apresenta relação de consumo de coagulante por água tratada bem inferior à ETA G. Tal acontecimento pode ser explicado pela ETA A apresentar-se a montante da ETA $G$ e podendo estar ocorrendo perda de qualidade do rio ao longo deste trecho (não é possível apresentar as características da água bruta das duas ETA porque a ETA A não forneceu tais informações).

Através dos dados da água bruta das ETA H e J apresentados na Tabela 26 e na Tabela 27 encontradas no Anexo B, plotou-se alguns parâmetros qualitativos para poder verificar se a qualidade da água bruta têm sofrido alterações ao longo do rio no decorrer do ano de 1996 (Figura 17).

Embora, fisicamente turbidez média não possua significado, aqui esta está sendo utilizada com objetivo de indicar possíveis alterações nas características da água bruta. 


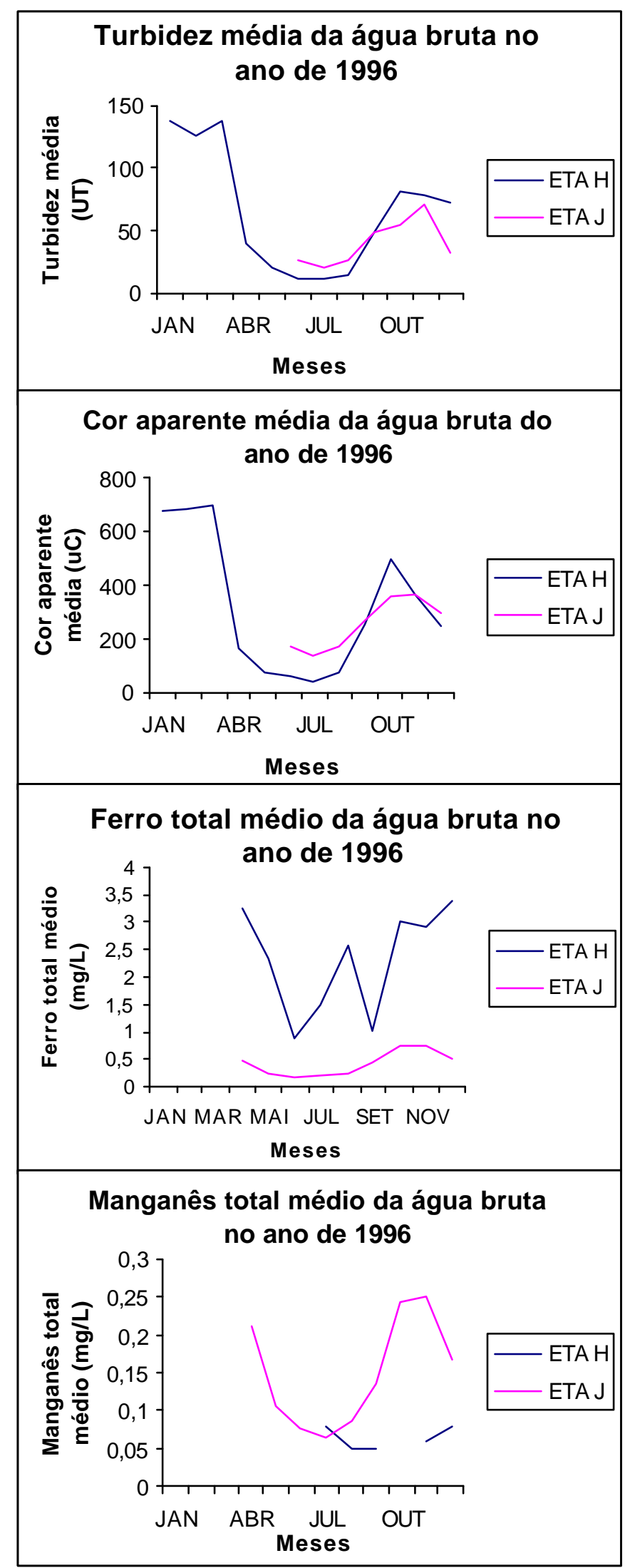

Figura 19: Características da água bruta das ETA H e J no ano de 1996 
Conforme mostra a Figura 17, para os parâmetros turbidez e cor aparente, a água bruta permanece praticamente sem alterações para as ETA H e J. A ETA J está a montante da ETA H. A água bruta que abastece a ETA $\mathrm{H}$ apresentou maior concentração de ferro, enquanto que a da ETA J possui maior concentração de manganês.

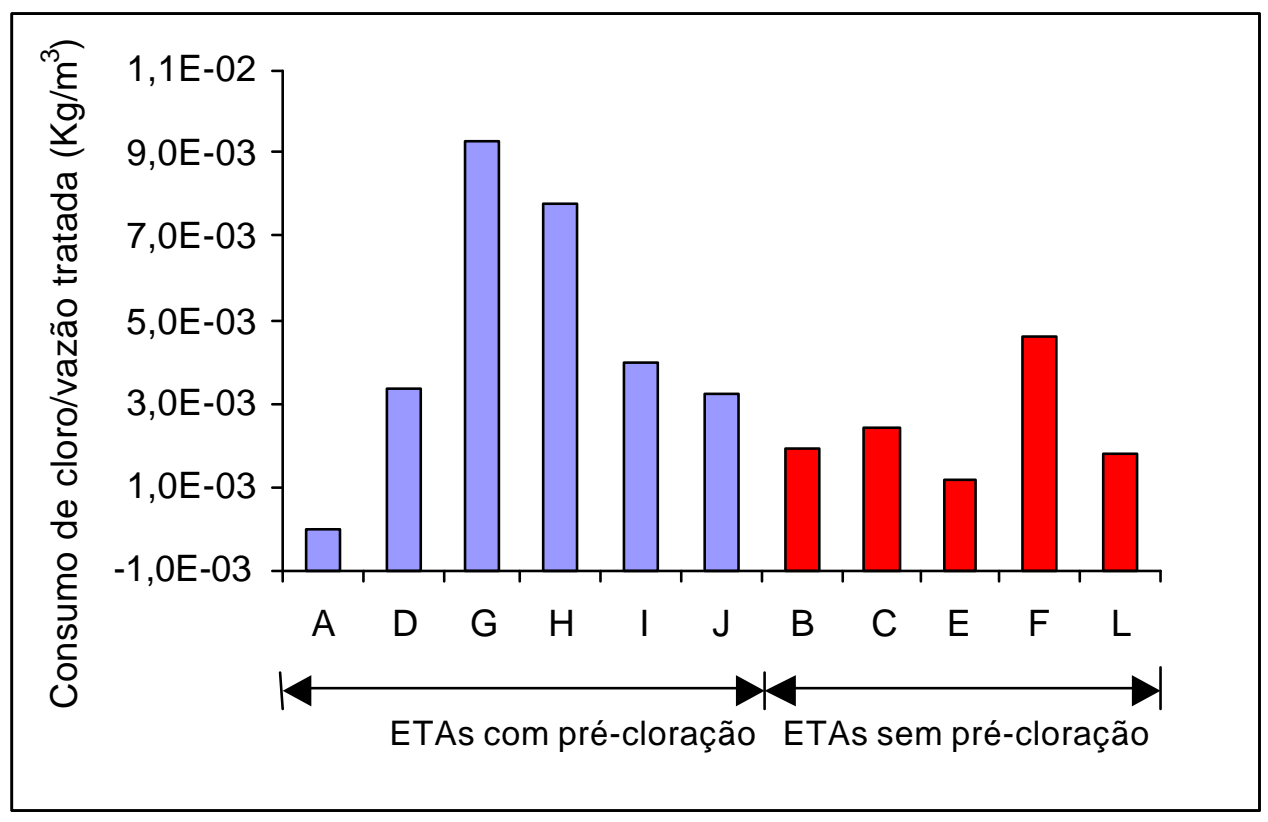

Figura 20: Consumo de cloro por vazão de água tratada $\left(\mathrm{kg} / \mathrm{m}^{3}\right)$

A Figura 18 mostra o consumo de cloro pelo volume de água tratada. A análise deste gráfico é muito semelhante a Figura 16, pois as ETA a jusante apresentam maior consumo de cloro por vazão de água tratada.

Conforme pode ser visto na Figura 18, 73\% das ETA com ou sem précloração apresentaram relação consumo de cloro por volume de água tratada da ordem de 0,002 a $0,003 \mathrm{~kg} \mathrm{Cl} / \mathrm{m}^{3}$ (2 a $\left.3 \mathrm{mg} / \mathrm{l}\right)$. 


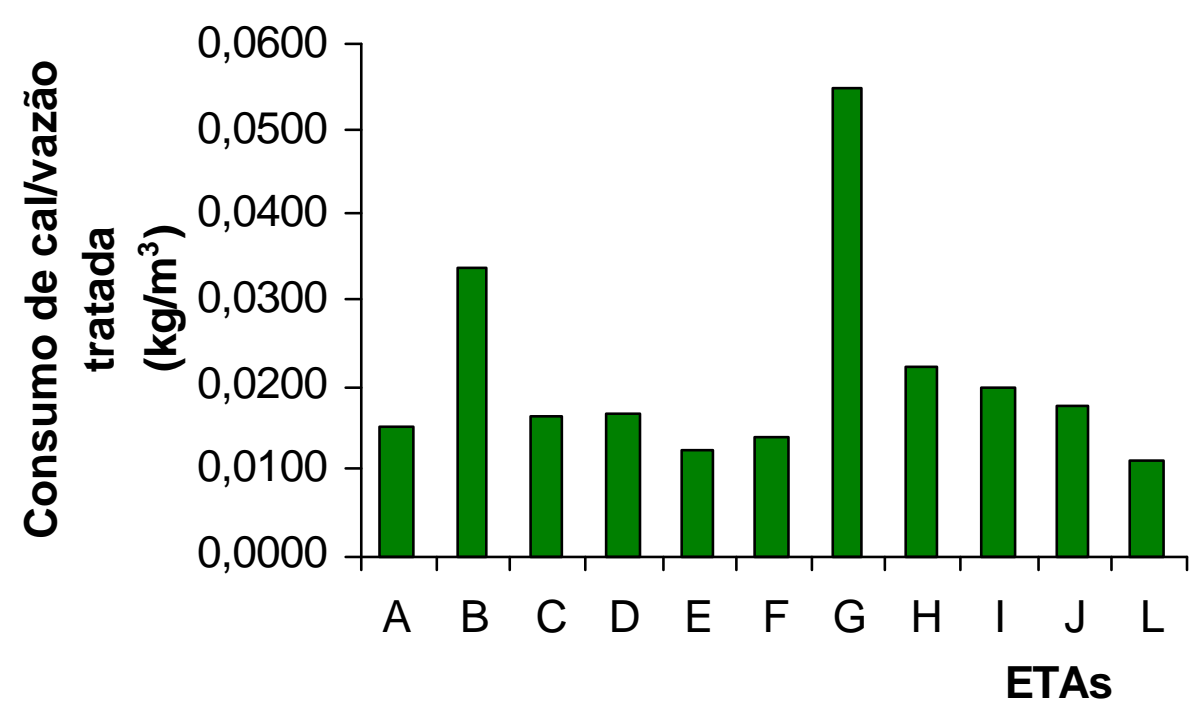

Figura 21: Consumo de cal por volume de água tratada $\left(\mathrm{kg} / \mathrm{m}^{3}\right)$

A Figura 19 mostra a quantidade de cal utilizada no processo de purificação pelo volume de água produzida. A ETA G novamente aparece com maior consumo de cal pela vazão de água tratada do que a ETA A, podendo ser devido ao decréscimo na qualidade da água bruta. As ETA H e J apresentaram relação de consumo de cal por vazão de água tratada aproximadamente iguais. A ETA B apresentou maior relação que a maioria das estações, essa ocorrência pode estar relacionada ao coagulante empregado no tratamento ser o cloreto férrico, para o qual trabalha-se com maior valor de $\mathrm{pH}$, de modo a necessitar de maior quantidade de cal no processo.

Através das Figuras 16, 18 e 19 pode-se perceber que o consumo de produto químico está diretamente relacionado à qualidade do manancial e que à medida que a qualidade da água bruta sofre decréscimo, utiliza-se maior quantidade de produtos para realizar o tratamento da mesma. 


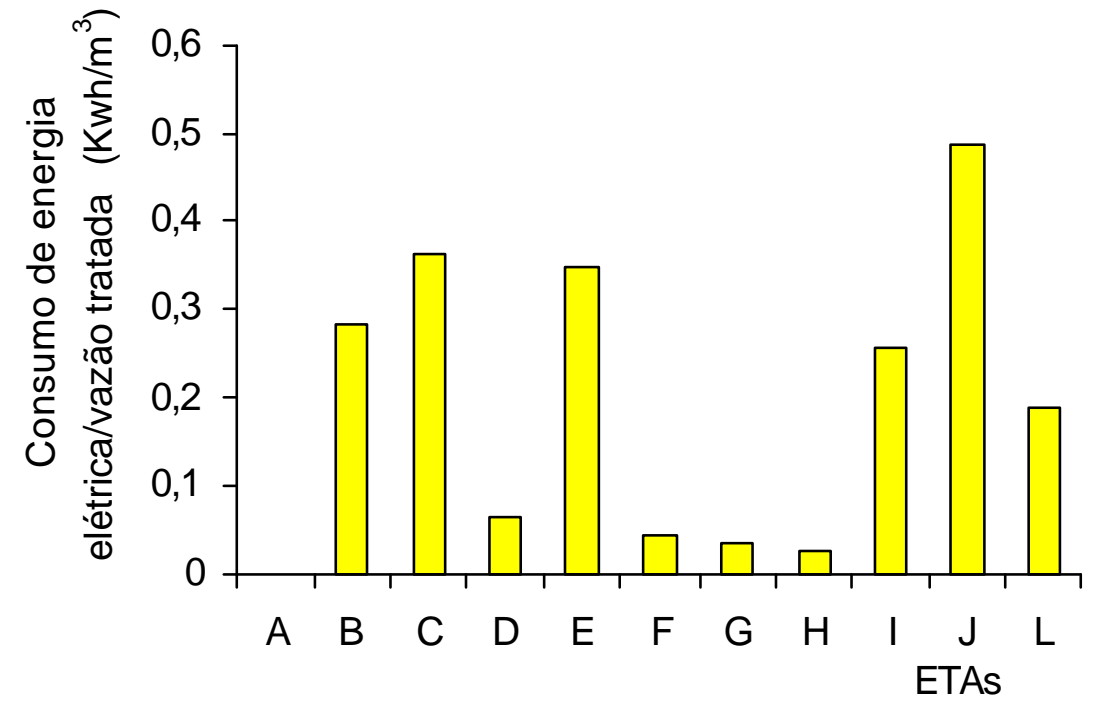

Figura 22: Consumo de energia elétrica por volume de água tratada $\left(\mathrm{kwh} / \mathrm{m}^{3}\right)$

O custo relativo a produtos químicos envolvidos no tratamento é uma das incógnitas que o gerente deveria estar preocupado, mesmo que hoje seja mais 'barato' gastar produto químico no tratamento do que efetuar programas de preservação dos mananciais, porque esta situação tende sofrer mudanças sob a ótica custo da água bruta. Outro fator que deveria ser considerado pelo responsável pela ETA é a quantidade de resíduos gerados no processo, pois estes estão diretamente ligados à quantidade de produtos químicos empregados no tratamento.

Na Figura 20, várias considerações devem ser feitas, à medida que a relação entre o consumo de energia elétrica pela quantidade de água tratada apresentada inclui a somatória do consumo de energia elétrica empregada no tratamento da água e do consumo de energia utilizada para distribuição da água tratada. As ETA não possuem valores isolados destes consumos de energia.

No consumo da ETA E está incluído também a energia elétrica consumida na captação, pois esta é realizada muito próxima a ETA, nota-se alta relação de consumo de energia elétrica por volume de água tratada.

A água pode ser distribuída por adução ou por gravidade, por isso é importante conhecer a distância da ETA aos reservatórios de distribuição e condições topográficas em que ambos se encontram. A ETA F realiza a distribuição da água 
tratada quase que em sua totalidade por gravidade, podendo ser este o motivo de apresentar baixo valor na relação estudada.

A ETA J fica distante da cidade, com isso o consumo de energia utilizado para o recalque da água tratada é elevado. Devido a insuficiência de informações no que diz respeito à distância da ETA aos reservatórios de abastecimento e em que cota ambos se encontram, não será possível analisar a relação consumo de energia elétrica por vazão tratada com maior efetividade.

O custo de energia envolvido no tratamento da água é um ponto importante para que o gerente possa fazer um balanço dos custos envolvidos no sistema. As informações obtidas mostra que nenhuma das estações visitadas sabe com precisão qual é o consumo de energia elétrica utilizada para tratar a água.

É comum entre as cidades fazer de forma simplista comparações entre os valores cobrados por $\mathrm{m}^{3}$ de água. De acordo com os dados apresentados pode-se dizer que tal comparação não deve ser realizada, pois cada município possui suas particularidades de forma a necessitar ou não de maiores gastos com produtos químicos e energia elétrica.

\subsection{Segurança no trabalho}

$\mathrm{O}$ treinamento dos operadores é fundamental no aspecto relacionado à segurança, pois é necessário o correto manuseio dos equipamentos e produtos químicos empregados no tratamento de água.

Os registros de acidentes nas ETA visitadas praticamente não existem. A maioria das estações de tratamento de água visitadas possuem equipamento de segurança conforme mostra a Tabela 25, sendo que os cuidados mais acentuados são no manuseio com a cal devido a poluição causada por particulados e com o cloro por ser um gás altamente tóxico. 
Tabela 25: Relação de equipamentos de segurança existentes nas ETA visitadas

\begin{tabular}{|c|l|}
\hline ETA & \multicolumn{1}{|c|}{ Equipamentos de segurança } \\
\hline A & $\begin{array}{l}\text { Máscara autônoma para gases, semi-máscaras para poeiras, extintor, bóia } \\
\text { salva vida, guarda corpo, iluminação nos decantadores. }\end{array}$ \\
\hline B & $\begin{array}{l}\text { Luva, óculos, bota, máscara para gás, máscara para pó, extintor, guarda } \\
\text { corpo, iluminação externa. }\end{array}$ \\
\hline C & $\begin{array}{l}\text { Botas, luvas, máscara de gases, máscara para pó, avental, extintor, } \\
\text { iluminação externa. }\end{array}$ \\
\hline D & $\begin{array}{l}\text { Equipamento autônomo para gás, luvas, botas, uniforme, máscara para pó, } \\
\text { guarda corpo, extintores, iluminação externa. }\end{array}$ \\
\hline E & $\begin{array}{l}\text { Máscara para gás, máscara para pó, extintor, luva de proteção para energia } \\
\text { elétrica, iluminação externa. }\end{array}$ \\
\hline F & $\begin{array}{l}\text { Equipamento autônomo para gases, bóia salva vida, luva, máscara para } \\
\text { preparo da cal, fone auditivo, uniforme, botas, detector de vazamento de } \\
\text { gás, extintor, iluminação externa. }\end{array}$ \\
\hline G & $\begin{array}{l}\text { Bóia salva vida, guarda corpo, luva, avental, máscara para pó, exaustor } \\
\text { para cal, equipamento autônomo para gases, bota, extintor, iluminação } \\
\text { externa. }\end{array}$ \\
\hline H & $\begin{array}{l}\text { Bóia salva vida, guarda corpo, detector de vazamento de gás, capa de } \\
\text { proteção, bota, aparelho de respiração autônoma, máscara facial, luva } \\
\text { térmica, luva de raspa, cinto, iluminação externa. }\end{array}$ \\
\hline I & $\begin{array}{l}\text { Máscaras individuais para pó, luvas de alta tensão, luvas para carga de cal, } \\
\text { botas, óculos de proteção, máscara para gás, bóia salva vida, guarda corpo, } \\
\text { iluminação externa. }\end{array}$ \\
\hline J & $\begin{array}{l}\text { Máscaras ndividuais para pó, luvas de alta tensão, luvas para carga de cal, } \\
\text { botas, óculos de proteção, máscara para gás, iluminação externa. }\end{array}$ \\
\hline L & $\begin{array}{l}\text { Luvas de borracha, botas de borracha, jalecos, máscaras automotivas, calça } \\
\text { com bota acoplada, máscaras para pó, gases e produtos químicos, óculos } \\
\text { de segurança, guarda corpo, iluminação externa. }\end{array}$ \\
\hline
\end{tabular}

De acordo com as informações mostradas na Tabela 25, cinco das estações de tratamento de água visitadas não possuem bóias salva-vidas e quatro ETA não têm guarda corpo, o que representa $45 \%$ e $36 \%$, respectivamente.

A iluminação externa está presente em todas as ETA, entretanto, normalmente esta é deficitária (número insuficiente de pontos de iluminação, localização prejudicada), o que dificulta o trabalho do operador noturno.

Máscara para gases, máscara para pó e extintor foram encontrados em todas as estações de tratamento visitadas. Equipamentos tal como lava-olhos para eventuais acidentes no laboratório não foi encontrado. Encontrou-se um chuveiro no laboratório da ETA $\mathrm{H}$ para casos de acidentes com produtos químicos. Aparentemente a ETA H é a mais segura por ser a estação de tratamento de água que 
apresentou maior quantidade de equipamentos, porém deve-se ressaltar que a segurança não está associada simplesmente ao fato da ETA possuir equipamentos, mas também de fazer uso dos mesmos. .

\subsection{Administração do Serviço de Água}

A Figura 23 mostra o organograma do serviço de água e esgoto da cidade L, não sendo este um modelo típico de administração.

O organograma possibilita visualizar onde está sendo enfocado o trabalho e qual o nível organizacional apresentado pela empresa.

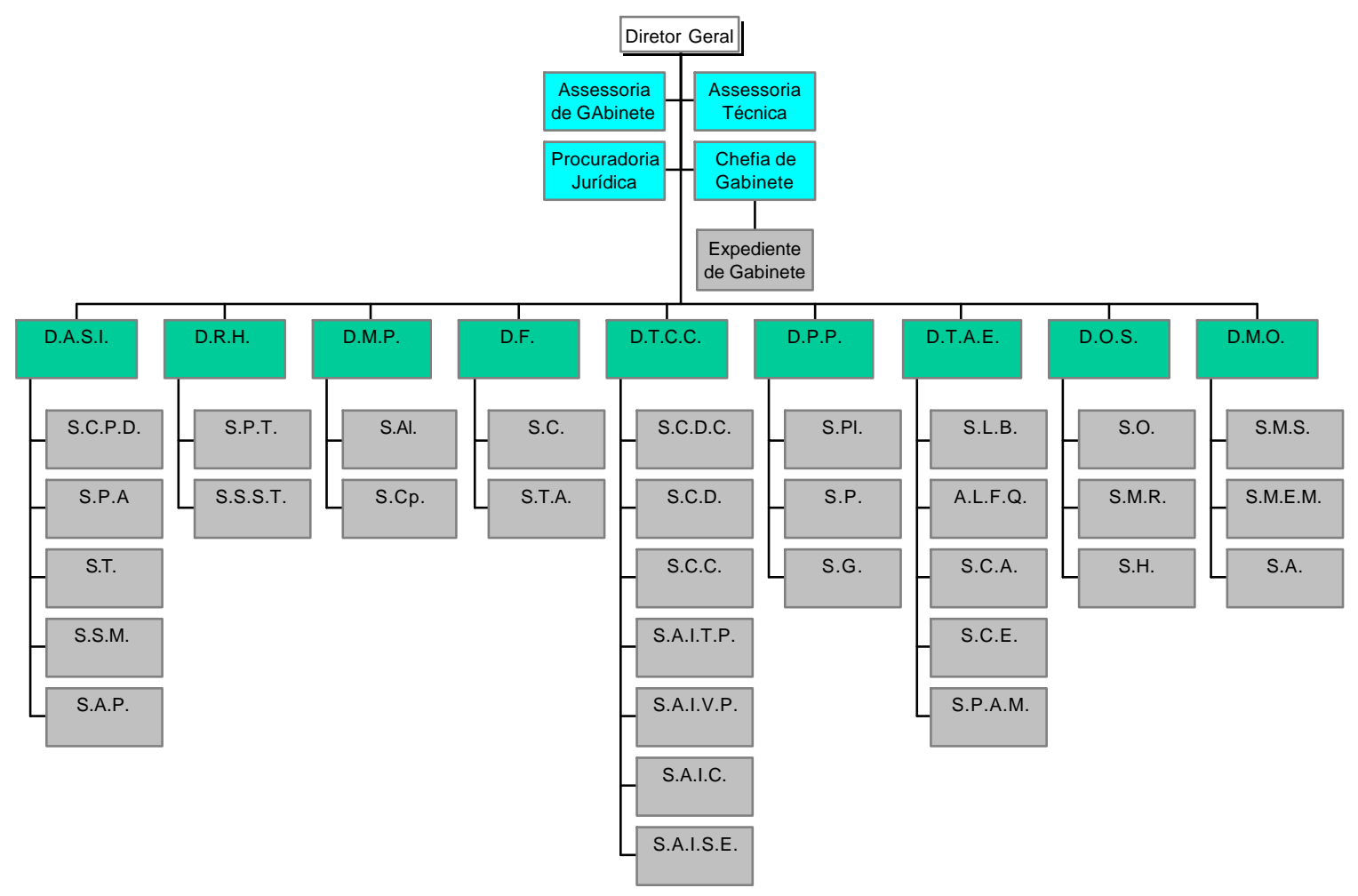

Figura 23: Organograma do Serviço de Abastecimento de Água da cidade $\mathrm{L}$

A seguir apresenta-se a descrição das divisões e respectivos setores do serviço de água e esgoto da cidade L. 
D.A.S.I. $\rightarrow$ DIVISÃO DE ADMINISTRAÇÃO E SERVIÇOS INTERNOS

S.C.P.D. (Setor de Controle e Processamento de Dados)

S.P.A. (Setor de Protocolo e Arquivo)

S.T. (Setor de Transportes)

S.S.M. (Setor de Serviços e Manutenção)

S.A.P. (Setor de Atendimento ao Público)

D.R.H $\rightarrow$ DIVISÃO DE RECURSOS HUMANOS

S.P.T. (Setor de Pessoal e Treinamento)

S.S.S.T. (Setor de Segurança e Saúde do Trabalhador)

D.M.P. $\rightarrow$ DIVISÃO DE MATERIAL E PATRIMÔNIO

S.Al. (Setor de Almoxarifado)

S.Cp. (Setor de Compras)

D.F. $\rightarrow$ DIVISÃO DE FINANÇAS

S.C. (Setor de Contabilidade)

S.T.A. (Setor de Tesouraria e Arrecadação)

D.T.C.C. $\rightarrow$ DIVISÃO DE TOMADA E CONTROLE DE CONTAS

S.C.D.C. ( Setor de Coleta e Distribuição de Contas)

S.C.D. ( Setor de Controle de Débitos)

S.C.C. (Setor Central de Controle)

S.A.I.T.P. (Setor de Atendimento e Informação do Tijuco Preto)

S.A.I.V.P. (Setor de Atendimento e Informação da Vila Prado)

S.A.I.C. (Setor de Atendimento e Informação do Central)

S.A.I.S.E. (Setor de Atendimento e Informação de Santa Eudóxia)

D.P.P $\rightarrow$ DIVISÃO DE PLANEJAMENTO E PROJETOS

S.P.L. (Setor de Planejamento)

S.P. (Setor de Projetos)

S.G. (Setor de Geoprocessamento) 
D.T.A.E. $\rightarrow$ DIVISÃO DE TRATAMENTO DE ÁGUA E ESGOTO

S.L.B. (Setor de Laboratório e Biologia)

S.L.F.Q. (Setor de Laboratório Físico Químico)

S.C.A. (Setor de Controle de Água)

S.C.E. (Setor de Controle de Esgoto)

S.P.A.M. (Setor de Proteção das Áreas e Mananciais)

D.O.S. $\rightarrow$ DIVISÃO DE OBRAS E SANEAMENTO

S.O. (Setor de Obras)

S.M.R. (Setor de Manutenção de Redes)

S.H. (Setor de Hidrometria)

D.M.O. $\rightarrow$ DIVISÃO DE MANUTENÇÃO E OPERAÇÃO

S.M.S. (Setor de manutenção do Sistema)

S.M.E.M. (Setor de manutenção e Eletro-Mecânica)

S.A. (Setor de Automação)

As Figuras 22, 23 e 24 apresentam organogramas de diferentes serviços de abastecimento de água, com o intuito de mostrar a diversidade e a complexidade organizacional destas empresas. 


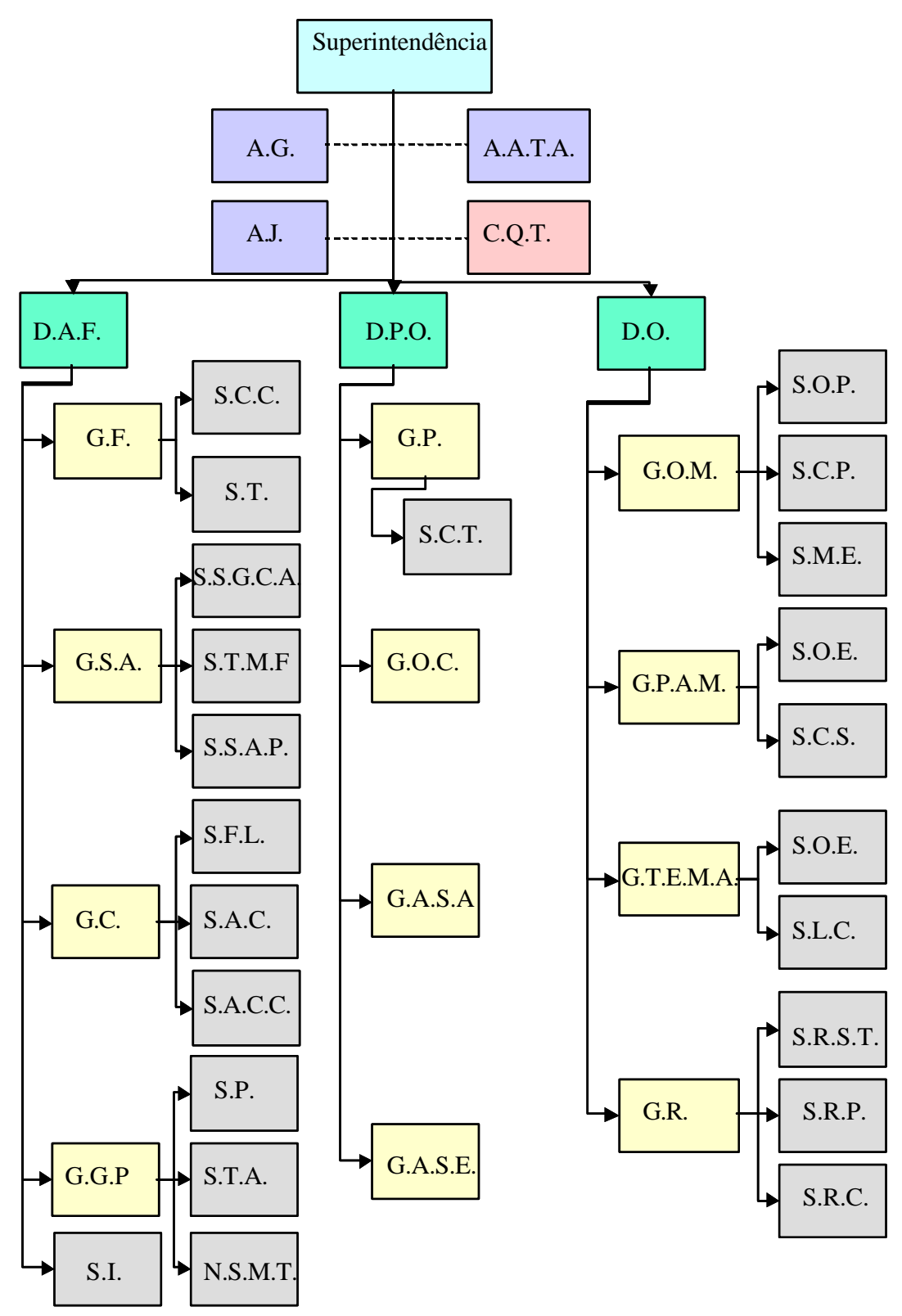

\section{Figura 24: Organograma Administrativo do Serviço de Água referente às ETA G e H}

O organograma administrativo mostrado na Figura 22 não é a estrutura atual da empresa de abastecimento de água em questão, sendo esta uma proposta organizacional do serviço, a qual terá sua implantação após ser votada pelos órgãos competentes.

A seguir, apresenta-se a descrição das divisões e respectivos setores do serviço de água e esgoto das ETA $\mathrm{G}$ e $\mathrm{H}$. 
A.G. $\rightarrow$ Assessoria de Gabinete

A.A.T.A. $\rightarrow$ Assessoria de Apoio Técnico - Administrativo

A.J. $\rightarrow$ Assessoria Jurídica

C.Q.T. $\rightarrow$ Comitê de Qualidade Total

D.A.F. $\rightarrow$ DIRETORIA ADMINISTRATIVO - FINANCEIRA

G.F. $\rightarrow$ Gerência de Finanças

S.C.C. $\rightarrow$ Seção de Contabilidade e Custos

S.T. $\rightarrow$ Seção de Tesouraria

G.S.A. $\rightarrow$ Gerência de Serviços de Apoio

S.S.G.C.A. $\rightarrow$ Seção de Serviços Gerais e Comunicação Administrativa

S.T.M.F. $\rightarrow$ Seção de Transporte e Manutenção da Frota

S.S.A.P. $\rightarrow$ Seção de Suprimentos, Almoxarifado e Patrimônio

G.C. $\rightarrow$ Gerência Comercial

S.F.L. $\rightarrow$ Seção de Fiscalização e Leituras

S.A.C. $\rightarrow$ Seção de Atendimento ao Consumidor

S.A.C.C. $\rightarrow$ Seção de Arrecadação e Controle de Contas

G.G.P. $\rightarrow$ Gerência de Gestão de Pessoal

S.P. $\rightarrow$ Seção de Pessoal

S.T.A. $\rightarrow$ Seção de Treinamento e Aperfeiçoamento

N.S.M.T. $\rightarrow$ Núcleo de Segurança e Medicina do Trabalho

S.I. $\rightarrow$ Seção de Informática

D.P.O. $\rightarrow$ DIRETORIA DE PROJETOS E OBRAS

G.P. $\rightarrow$ Gerência de Planejamento

S.C.T. $\rightarrow$ Seção de Cadastro Técnico

G.O.C. $\rightarrow$ Gerência de Obras Civis

G.A.S.A. $\rightarrow$ Gerência de Ampliação do Sistema de Água 
G.A.S.E. $\rightarrow$ Gerência de Ampliação do Sistema de Esgoto

D.O. $\rightarrow$ DIRETORIA OPERACIONAL

G.O.M. $\rightarrow$ Gerência de Operação e Manutenção

S.O.S. $\rightarrow$ Seção de Operação de Sistema

S.C.P. $\rightarrow$ Seção de Controle de Perdas

S.M.E. $\rightarrow$ Seção de Manutenção Eletromecânica

G.P.A.M. $\rightarrow$ Gerência de Produção de Água e Mananciais

S.O.E. $\rightarrow$ Seção de Operação de ETA

S.C.S. $\rightarrow$ Seção de Controle Sanitário

G.T.E.M.A. $\rightarrow$ Gerência de Tratamento de Esgoto e Meio Ambiente

S.O.E. $\rightarrow$ Seção de Operação de ETEs

S.L.C. $\rightarrow$ Seção de Laboratório e Controle

G.R. $\rightarrow$ Gerência das Regionais

S.R.S.T. $\rightarrow$ Seção Regional Santa Terezinha

S.R.P. $\rightarrow$ Seção Regional Paulicéia

S.R.C. $\rightarrow$ Seção Regional do Centro

A Figura 23 mostra o organograma administrativo da ETA E, a menor cidade em estudo.

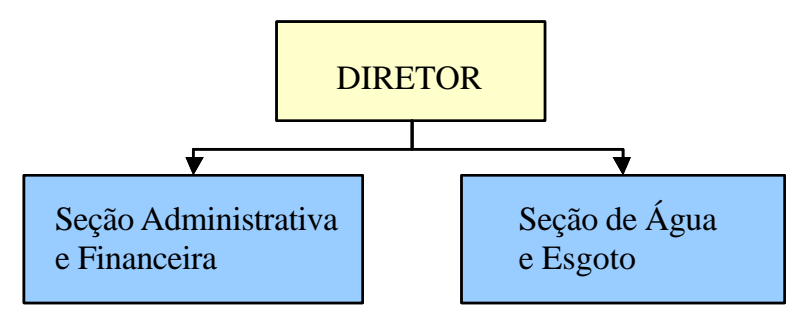

Figura 25: Organograma administrativo da ETA E 


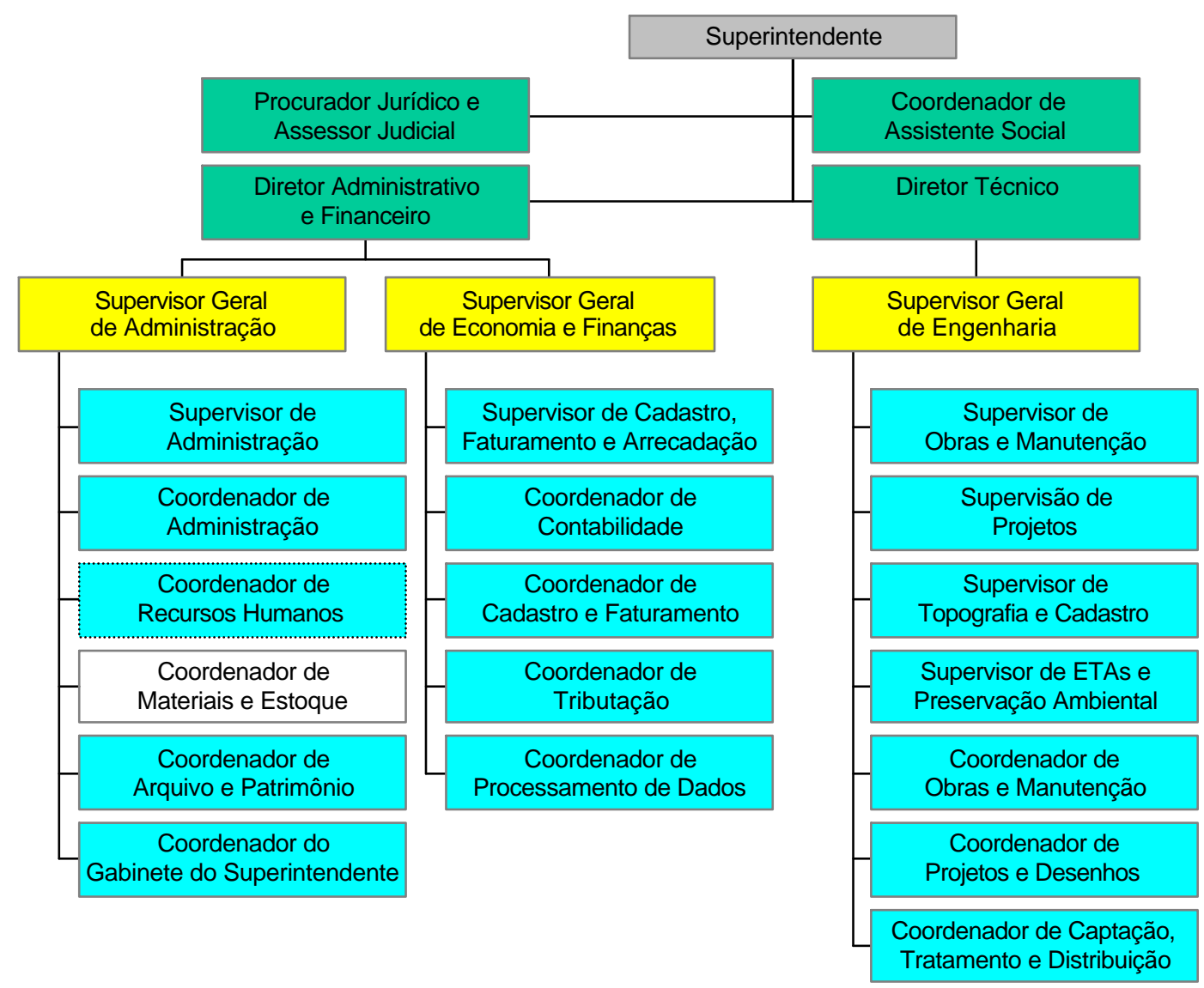

Figura 26: Organograma do Serviço de Abastecimento de Água das ETA I e J.

Pelos organogramas apresentados nota-se diferenças no segmento administrativo dos serviços de água. Percebe-se que a ETA L apresenta organograma melhor definido que as ETA E, I e J, porém a administração com pensamentos mais modernos encontra-se nas ETA G e H. Entretanto tais ETA ainda não apresentam visão sistêmica do serviço por elas prestadas quando criam uma gerência de produção de água e mananciais e outra para tratamento de esgoto e meio ambiente, pois as ETA geram resíduos que lançados no meio ambiente podem prejudicá-lo, contudo no pensamento gerencial da empresa o meio ambiente esta associado somente a tratamento de esgoto e não ao tratamento de água.

O fato da empresa possuir um organograma administrativo é um indicativo do nível gerencial na qual esta se encontra porém, não significa que esta esteja desempenhando os papéis por este estabelecido. 


\subsection{Modelo gerencial para estação de tratamento de água de abastecimento}

A Figura 25 foi reproduzida a partir da Figura 8 com o objetivo de detalhar as atividades para as estações de tratamento de água.

$\mathrm{Na}$ entrada do processo têm-se água bruta, produtos químicos, as expectativas dos consumidores e o pessoal administrativo e técnico. O projeto em questão é uma estação de tratamento de água completa cujo objetivo é produzir água com qualidade, confiabilidade, em quantidade, com regularidade e baixo custo. Para atingir tais objetivos será necessário o planejamento e o controle da qualidade e da quantidade da água bruta e da água tratada, bem como dos produtos químicos empregados. $\mathrm{O}$ processo exige sempre melhorias e por isso é imprescindível o gerenciamento da qualidade e o contínuo aprimoramento do tratamento. Se a água tratada não apresenta a qualidade desejada algumas medidas são tomadas de forma a atingir o objetivo da empresa. Para permitir que a empresa obtenha os resultados esperados são estabelecidas estratégias, ou seja, ações ou decisões que posiciona a organização em seu ambiente e têm o objetivo de fazê-la atingir seus objetivos a longo prazo.

Política bem definida (melhoria no abastecimento, melhoria na qualidade da água tratada, melhoria no atendimento ao cliente, etc.) é requisito primordial para as empresas que pretendem atingir sucesso em sua atividade, pois sem o estabelecimento da política não é possível planejar os programas e ações que deverão ser implantados para obtenção de resultados. 


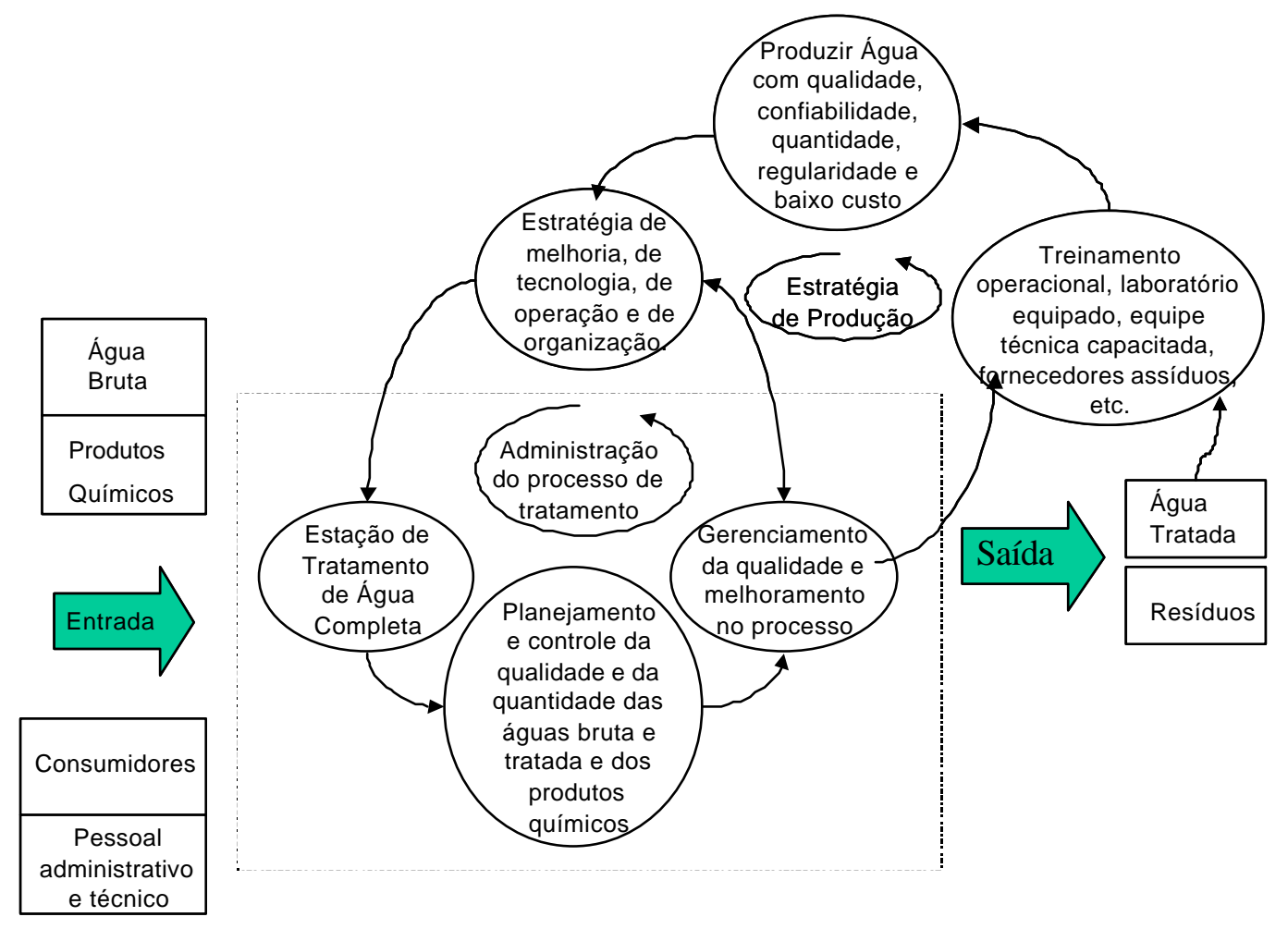

Figura 27: Modelo geral de administração para estação de tratamento de água

A quantidade de informações obtidas em cada ETA, bem como a importância e a utilização desses dados pelos gerentes é uma questão que merece ser comentada.

$\mathrm{O}$ fato da empresa possuir uma gama enorme de dados não garante que os responsáveis estão empregando essas informações de modo a conseguir um tratamento mais adequado, no sentido de diminuir seus custos, mantendo a mesma qualidade da água tratada. A ausência de dados provoca maior preocupação ainda, pois se houver interesse em realizar um estudo gerencial na estação o pesquisador deverá fazer todo esse levantamento para que após alguns anos, ele possa vir a desenvolver a pesquisa.

De acordo com levantamento realizado no Departamento de Hidráulica e Saneamento da USP de São Carlos várias pesquisas tecnológicas têm sido desenvolvidas para o processo de tratamento de água, entretanto, notou-se pequena transferência destas tecnologias para as estações de tratamento visitadas. A troca de informações entre instituições de pesquisa e ETA deveriam estar ocorrendo com maior intensidade, pois a pesquisa é realizada justamente para trazer melhorias para os sistemas. 
A visão gerencial dentro de uma ETA caminha ainda muito lentamente, porque o conceito de gerenciamento ainda é muito estreito sob a ótica do responsável que pensa que administrar um serviço é organizar suas operações e processos de forma a produzir água com padrão de qualidade que atenda à legislação, o que também é importante, porém não é só isso que deve acontecer. A água que chega ao consumidor deve ter além de qualidade, qualidade dos serviços prestados com o menor custo possível, o que somente é possível quando um programa de gerenciamento é implantado na empresa tendo a adesão de todos os níveis do serviço. 


\section{CONCLUSÕES}

Com o estudo desenvolvido pode-se concluir que:

1. Algumas ETA visitadas dispõem de poucos dados históricos, impossibilitandonos discuti-las com maior efetividade e mostrando que pouca atenção tem sido dada às informações.

2. De uma maneira geral não tem existido por parte dos sistemas gerenciadores grandes preocupações com a manutenção da qualidade dos mananciais o que implica na piora da qualidade da água e aumento de produtos químicos.

3. Em 73\% (8 ETA) das estações de tratamento de água visitadas, verificou-se condições de trabalho com vazão de água igual ou maior que a de projeto.

4. A aquisição dos produtos químicos é realizada pelo menor preço. O controle de qualidade dos produtos químicos adquiridos é realizado por seis ETA visitadas (56\%), contudo as mesmas não analisam todos os parâmetros contidos no edital de licitação.

5. O consumo de produto químico está diretamente relacionado à qualidade do manancial; à medida que a qualidade da água bruta decresce, utiliza-se maior quantidade de produtos para realizar o tratamento da mesma.

6. Somente $45 \%$ (5) das ETA visitadas adotavam critério técnico ("jar-test") para fazer as dosagens de produtos químicos, sendo que o restante utilizava-se de conhecimento empírico para realização do tratamento da água, ou seja, sem acompanhamento efetivo de equipamento.

7. O controle efetivo da qualidade da água tratada (seguindo a Portaria 36/GM de 1990 do Ministério da Saúde) é realizado em todas as ETA. As estações de tratamento de água de maneira geral encontram-se com laboratórios bem equipados, ficando em alguns casos somente as análises requeridas semestralmente para serem efetuadas fora do local. 
8. Os dados levantados revelaram que somente uma ETA recupera parte das águas de lavagem de filtros em cerca de $64 \%$.

9. 64\% (7) das estações de tratamento de água para abastecimento visitadas realizam acompanhamento efetivo da água decantada, filtrada e distribuída.

10. Verificou-se através de dados levantados que as ETA G e H apresentaram perda de água no ano de 1996 igual a 5,7\% e 4,8\% respectivamente.

11. Em $36 \%$ das ETA (quatro estações) visitadas o controle da quantidade de água utilizada na limpeza dos filtros é efetivo com acompanhamento do volume utilizado. Nas demais empregam-se estimativas.

12. Em dez das onze estações de tratamento de água visitadas, os resíduos gerados nos decantadores e filtros são descartados nos cursos d'água próximos às ETA, podendo estar infringindo legislação de controle de emissão de poluentes, não havendo preocupação em recuperação da água de lavagem.

13. O nível de escolaridade do operadores de ETA, conforme dados levantados é relativamente baixo: $32 \%$ apresentaram $1^{\circ}$ grau incompleto e $30 \%$ o $1^{\circ}$ grau completo, ou seja, mais da metade do pessoal que tem trabalhado no tratamento de água possuem no máximo primeiro grau.

14. Percebe-se que nas empresas de saneamento as chefias são confiadas normalmente a engenheiros.

15. O custo de energia envolvido no tratamento da água é um ponto importante para que o gerente possa fazer um balanço dos custos envolvidos no sistema. As informações obtidas mostram que nenhuma das estações visitadas conhece com precisão qual é o consumo de energia elétrica utilizada para tratar a água.

16. Os registros de acidentes nas ETA visitadas praticamente não existem. A maioria das estações de tratamento de água visitadas possuem equipamentos de segurança mínima e os cuidados são mais acentuados no manuseio com a cal devido a poluição causada por particulados e com o cloro por ser um gás altamente tóxico.

17. O fato da empresa possuir um organograma administrativo é um indicativo do nível gerencial na qual esta se encontra, porém não significa que esta esteja desempenhando os papéis por este estabelecido. 
18. O fato de dispor de dados não significa que o processo está sendo bem gerenciado, pois poucos gerentes tem utilizado os resultados das análises para fim de planejamento.

19. Notou-se pequena transferência de tecnologia desenvolvida em estudos científicos na operação das estações de estações de tratamento de água estudadas.

20. Dos resultados obtidos e das conclusões acima pode-se observar a necessidade da implantação de sistemas gerenciais mais efetivos nas ETA, uma vez que os serviços de abastecimento de água devem iniciar trabalhos voltados para melhoria da qualidade do serviço e do produto. 


\section{PROPOSTAS}

A pesquisa realizada possibilitou fazer propostas que permitam melhor aproveitamento das informações disponíveis nas estações de tratamento de água, bem como promover discussões à respeito da necessidade da visão holística do gerente.

Com relação aos mananciais propõe-se que seja realizado efetivo acompanhamento histórico das condições dos mesmos, levando-se em conta aspectos tais como:

- Condições de utilização das margens e área de proteção dos mananciais;

- acompanhamento qualitativo das condições dos mananciais, através de análises químicas, físicas e biológicas;

- com os dados sistematizados elaborar plano de acompanhamento da evolução dos parâmetros no decorrer do tempo (construção de gráficos, etc.);

- estabelecimento de programas de proteção utilizando legislação pertinente;

- zoneamento ambiental.

Os sistemas que operam com os mesmos mananciais (ou até na mesma bacia) devem trocar experiências em relação à evolução da qualidade da água e formas de tratamento e gerenciamento por estes empregados.

Estudos da água bruta para verificar a possibilidade e a viabilidade de implantação de outros equipamentos (flotadores, por exemplo) no processo de tratamento de água.

Estudos da água bruta com intuito de realizar a filtração direta em determinados períodos do ano. 
Se a ETA estiver trabalhando com vazão superior a de projeto, deve-se realizar estudos e fazer projeto de ampliação para a mesma ou construção de nova ETA.

Aquisição de produtos químicos de firmas que sejam credenciadas em órgão fiscalizador.

Utilização de "jar-test” para realização da dosagem de produtos químicos.

Acompanhamento efetivo do processo de tratamento de água (floculada, decantada, filtrada e distribuída).

Controle efetivo do consumo de água utilizada na lavagem dos filtros e decantadores e nas descargas realizadas nos tanques de sedimentação.

Estudos da água de lavagem para reutilização desta no processo de tratamento.

Realização de estudo para dar destino adequado aos resíduos gerados.

Elaboração de planilha com cadastro das bombas utilizadas na ETA, bem como registro de troca e manutenção das mesmas.

Estabelecimento de programa de manutenção das estruturas da ETA, da parte elétrica, hidráulica, mecânica, etc.

Implantação de marcadores de níveis nos filtros e no canal de entrada aos filtros.

Identificação visual (método colorimétrico) das tubulações de coagulante, cal, cloro, água bruta e tratada, etc. dentro da estação. 
Elaboração de manual de operação da ETA

Implantação de programa de controle de perdas de água na ETA.

Aplicação de cursos de aperfeiçoamento para responsáveis e operadores.

As ETA devem adquirir e exigir que seus funcionários usem equipamentos de segurança.

Elaboração de relatórios anuais contendo informações resumidas das características das águas bruta, tratada e distribuída.

Estabelecimento de convênio entre ETA e instituições de ensino de forma a aumentar a troca de informações entre ambas.

Tornar efetiva a transferência de tecnologia desenvolvida em instituições de pesquisa e as estações de tratamento de água.

Dessa forma, vários trabalhos poderiam estar sendo realizados, dentre eles podem ser citados:

1. Levantamento e análise de custo de ETA com o objetivo de levantar as porcentagens relacionadas a cada item utilizado no processo (produtos químicos, energia, recursos humanos, manutenção, etc..)

2. Levantamento de custo de 2 cidades do mesmo porte e fazer comparações.

3. Levantar custo de administrações diferentes e compará-las.

4. Estudar uma ETA e para esta desenvolver um programa gerencial compatível com a mesma.

5. Desenvolver junto à empresa um programa de preservação e recuperação dos mananciais. 
6. Desenvolver apostilas para treinamento do pessoal da ETA, tratando de operação, segurança, manuseio com produtos químicos, conhecimento da ETA como um todo, entre outros.

7. Pesquisa sobre a qualidade de vida do operador de ETA em relação ao turno trabalhado. Pode-se verificar quais as alterações (prejuízos) sofridas pelos funcionários decorrente dos vários tipos de turnos existentes.

8. Desenvolver trabalho estatístico sobre qualidade da água (bruta ou tratada) de uma ETA no decorrer de vários anos. 


\section{ANEXO A}

\section{MODELO \\ Orientações básicas para elaboração de editais}

O edital deve deixar claras as condições para fornecimento de produtos químicos e especificar que o material será analisado segundo normas da ABNT. O fornecedor deve ser orientado de que produtos fora de especificação serão glosados ou devolvidos.

\section{QUALIDADE DO PRODUTO:}

Ácido Fluosilícico $\left(\mathbf{H}_{2} \mathbf{S i F}_{6}\right)$ - É utilizado no tratamento de água para abastecimento público, por isso, não deve conter substâncias minerais ou orgânicas em quantidade que torne a água tratada imprópria para consumo humano, ou seja, fora dos padrões de portabilidade prescritos pela Portaria 36, do Ministério da Saúde.

Como deve ser: Líquido corrosivo, fortemente ácido, odor pungente, isento de material em suspensão, coloração que varia de incolor a amarelo palha.

Teor de $\mathrm{H}_{2} \mathrm{SiF}_{6}$ ..mínimo 20,00\%

Acidez devida a outros ácidos, expressa em HF máxima $1,00 \%$

Metais pesados expressos em PB máximo $0,02 \%$

Cal Hidratada - Deve ser do tipo especial para tratamento de água, com as seguintes características:

Teor em $\mathrm{Ca}(\mathrm{OH})_{2}-$ (Hidróxido de Cálcio) mínimo $90,0 \%$

Teor em $\mathrm{CaOH}$ - (Óxido de Cálcio) .mínimo 66,1\%

Teor em $\mathrm{CaCO}_{3}-($ Carbonato de Cálcio) máximo $5,5 \%$ 
Hipoclorito de Sódio: Produto utilizado como desinfectante no tratamento de água para abastecimento público. Solução aquosa, alcalina, de coloração amarelada e límpida. O produto não deve conter substâncias minerais ou orgânicas, solúveis ou em suspensão, em quantidade que tornem a água tratada imprópria para o consumo humano.

Teor de cloro ativo - (\% em massa como $\mathrm{Cl})$ mínimo $10,0 \%$

Hidróxidos - (\% em massa de $\mathrm{NaOH})$ mínimo $0,5 \%$

Sulfato de Alumínio: Produto utilizado como coagulante no tratamento de água para abastecimento público, obtido à partir do ataque da bauxita pelo ácido sulfúrico, que deverá Ter pureza suficiente para não conferir ao produto final quaisquer contaminantes, quer seja orgânico ou inorgânico, em especial, metais pesados.

Granulado Líquido

$\begin{array}{lcc}\text { Alumínio total }\left(\% \text { em massa de } \mathrm{Al}_{2} \mathrm{O}_{3}\right) & \text { min14,0 } & 7,5 \% \\ \text { Ferro total }\left(\% \text { em massa de } \mathrm{Fe}_{2} \mathrm{O}_{3}\right) & \text { máx 2,5 } & 1,2 \% \\ \text { Resíduo insolúvel em água }(\% \text { em massa) } & \text { máx 6,0 } & 0,2 \% \\ \left.\text { Acidez livre(\% em massa como } \mathrm{H}_{2} \mathrm{SO}_{4}\right) & \text { máx } 0,5 & 0,5 \% \\ \text { Basicidade }\left(\% \text { em massa como } \mathrm{Al}_{2} \mathrm{O}_{3}\right) & \text { máx } 0,4 & 0,2 \%\end{array}$

ATESTADOS: Deverá ser apresentado junto com as propostas, atestados de, no mínimo, duas empresas que comprovem que a proponente prestou, ou vem prestando, serviços de fornecimento do produto determinado, em quantidade igual ou superior a mencionada neste processo.

ENTREGA DO PRODUTO: Deverá ser entregue mediante programação e conforme necessidades do SAAE.

RECEBIMENTO DO PRODUTO: A cada remessa será efetuada coleta de amostra conforme ABNT. Será autorizada a descarga do produto após liberação pelo laboratório que efetuará as análises, em conformidade com as normas da ABNT. O 
veículo da entrega será pesado antes e depois do descarregamento. As partidas do produto que não obedecerem às especificações contidas no item 1 poderão, a critério do SAAE, ser rejeitadas na sua totalidade, após análises, independentemente de o produto ser descarregado ou não, ficando as despesas financeiras por conta do fornecedor. As partidas com teores abaixo do especificado poderão ser aceitas, a critério do SAAE, obrigando-se a fornecedora a aceitar glosa nos correspondentes pagamentos a serem efetuados pelo SAAE, através da fórmula:

Para ácido fluossilícico: $\quad \frac{V G=V U x(20-T) x P}{100}$

onde: VG: valor a ser glosado nos pagamentos devidos à fornecedora

VU: preço unitário vigente do produto(R $\$ / T o n$.

T: teor de $\mathrm{H}_{2} \mathrm{SiF}_{6}$ verificados analiticamente(\%)

P: peso da partida submetida à análise

Para cal hidratada: $\quad \frac{V G=V U x(90-T i) x P}{100}$

onde: VG: valor a ser glosado nos pagamentos devidos à fornecedora

VU: preço unitário do produto(R $\$ / T o n$.

Ti: teor de hidróxido de cálcio verificado analiticamente(\%)

P: peso da partida submetida à análise

Para hipoclorito de sódio: $\quad \frac{V G=V U x(10-R) x P}{10}$

onde: VG: valor a ser glosado nos pagamentos devidos à fornecedora

VU: preço unitário do produto(R/Ton.)

$\mathrm{R}$ : teor de cloro ativado verificado analiticamente

$\mathrm{P}$ : peso da partida submetida à análise

Para sulfato de alumínio: $\quad \frac{V G=V n x(T a-T I)}{T I}$

onde: VG: valor a ser glosado nos pagamentos devidos à fornecedora

Vn: valor da nota fiscal

Ta: valor mínimo exigido na especificação

TI: teor de alumínio verificado analiticamente 
AMOSTRA DO PRODUTO: As firmas interessadas deverão entregar amostras do produto ao $\mathrm{SAAE}$, com determinado número de dias antes da data de abertura deste processo, para análises laboratoriais. As amostras que estiverem com teores abaixo do especificado no item 1 estarão impossibilitadas de participar da abertura das propostas.

Fonte: Revista Saneamento e Municípios (Dezembro96/Janeiro97) 
ANEXO B 
Tabela 26: Fornecedores de produtos químicos das estações de tratamento de água visitadas referentes ao ano de 1996.

\begin{tabular}{|c|c|c|c|c|c|}
\hline \multirow[t]{2}{*}{ ETA } & \multicolumn{5}{|c|}{ PRODUTO QUÍMICO } \\
\hline & Sulfato de alumínio & Cloreto férrico & Cal & Cloro & Fluorsilicato de sódio \\
\hline A & Guaçú - Mogi-Guaçú/SP & & Arco-Íris - Formiga/ MG & Carbocloro - Cubatão/SP & \\
\hline B & & $\begin{array}{l}\text { Nheel Química - Rio } \\
\text { Claro/SP }\end{array}$ & Arco-Íris - Formiga/ MG & Carbocloro - Volta Redonda/RJ & \\
\hline $\mathrm{C}$ & $\begin{array}{l}\text { QRV - São João da Boa } \\
\text { Vista/SP }\end{array}$ & & Brasical - Pains/MG & $\begin{array}{llll}\text { Sabará - Santa Bárbara do } \\
\text { Oeste/SP }\end{array}$ & \\
\hline $\mathrm{D}$ & $\begin{array}{l}\text { Nheel Química }- \text { Rio } \\
\text { Claro/SP }\end{array}$ & & Arco-Íris - Formiga/ MG & Carbocloro - Cubatão/SP & \\
\hline $\mathrm{E}$ & $\begin{array}{l}\text { QRV - São João da Boa } \\
\text { Vista/SP }\end{array}$ & & Brasical - Pains/MG & $\begin{array}{llll}\text { Sabará - Santa Bárbara do } \\
\text { Oeste/SP }\end{array}$ & Cataguases - Cataguases/ MG \\
\hline $\mathrm{F}$ & $\begin{array}{l}\text { Nheel Química - Rio Claro/ } \\
\text { SP }\end{array}$ & & Itaú - Arcos/MG & $\begin{array}{llll}\begin{array}{l}\text { Sabará - Santa Bárbara do } \\
\text { Oeste/SP }\end{array} & & \\
\end{array}$ & \\
\hline $\mathrm{G}$ & & Guaçú -Mogi-Guaçú/SP & Arco-Íris - Formiga/ MG & $\begin{array}{llll}\begin{array}{l}\text { Sabará - Santa } \\
\text { Oeste/SP }\end{array} & & & \\
\end{array}$ & Adesol - São Paulo/SP \\
\hline $\mathrm{H}$ & $\begin{array}{l}\text { Nheel Química - Rio Claro/ } \\
\text { SP }\end{array}$ & & Arco-Íris - Formiga/ MG & $\begin{array}{llll}\begin{array}{l}\text { Sabará - Santa } \\
\text { Oeste/SP }\end{array} & \text { Bárbara do } \\
\end{array}$ & Adesol - São Paulo/SP \\
\hline $\mathrm{I}$ & & Guaçú - Estivas & Calc. N. S ${ }^{\text {a Guia/MG }}$ & Hidromar - Cubatão/SP & \\
\hline $\mathrm{J}$ & & Guaçú - Estivas & Calc. N. S ${ }^{\mathrm{a}}$ Guia/MG & Hidromar - Cubatão/SP & \\
\hline $\mathrm{L}$ & Guaçú-Mogi Guaçú/SP & & Itaú - Itaú/MG & $\mathrm{CG}-$ Cruzeiro/SP & \\
\hline
\end{tabular}


Tabela 25: Fornecedores de produtos químicos das estações de tratamento de água visitadas referentes ao ano de 1996 (Continuação).

\begin{tabular}{|c|l|l|l|l|l|}
\hline \multirow{2}{*}{ ETA } & \multicolumn{5}{|c|}{ PRODUTO QUÍMICO } \\
\cline { 2 - 6 } & \multicolumn{1}{|c|}{ Ácido fluossilícico } & Carvão ativado & Polímero natural & Sulfato de amônia & Polifosfato de sódio \\
\hline A & Liquisul - São Paulo/SP & Paiol / Sul & & & \\
\hline B & Saneclor - Cruzeiro/SP & & & & \\
\hline C & Cataguases - Cataguases/MG & & Dearbosn Sorocaba/SP & & \\
\hline D & & & & & \\
\hline E & \multicolumn{1}{|l|}{$\begin{array}{l}\text { Grace - Dearborn } \\
\text { F }\end{array}$} & Nitro Química - São Miguel & & Nheel Química - Rio Claro/SP & Amon - EUA \\
\hline G & Paulista/SP & & & & \\
\hline H & & Guaçu-Mogi-Guaçú/SP & & & \\
\hline I & Sanecor - Cruzeiro/SP & & & & \\
\hline J & Sanecor - Cruzeiro/SP & & & & \\
\hline L & Cloromatic Sumaré/SP & & & & \\
\hline
\end{tabular}


Tabela 27: Características da água bruta da ETA H referente ao ano de 1996 . Valores médios mensais.

\begin{tabular}{|c|c|c|c|c|c|c|c|c|c|c|c|c|}
\hline MES & JAN & FEV & MAR & $\mathrm{ABR}$ & MAI & JUN & JUL & AGO & SET & OUT & $\mathrm{NOV}$ & DEZ \\
\hline Turbidez (uT) & 138 & 127 & 137 & 39 & 20 & 11 & 11 & 14 & 49 & 81 & 78 & 72 \\
\hline Cor Aparente(uC) & 675 & 685 & 695 & 164 & 74 & 56 & 40 & 70 & 260 & 500 & 370 & 250 \\
\hline $\begin{array}{l}\text { Oxigênio } \\
\text { Consumido }(\mathrm{mg} / \mathrm{l})\end{array}$ & 8.6 & 8.3 & 10.5 & 5.7 & 4.0 & 3.7 & 3.8 & 4.1 & 6.0 & 7.7 & 6.5 & 5.5 \\
\hline $\mathrm{pH}$ & 6.9 & 6.9 & 6.9 & 7.0 & 6.9 & 6.9 & 6.8 & 6.8 & 6.8 & 6.8 & 6.9 & 6.9 \\
\hline $\begin{array}{l}\text { Alcalinidade Total } \\
\left(\mathrm{mg} / \mathrm{CaCO}_{3}\right)\end{array}$ & 22 & 21 & 20 & 18 & 18 & 19 & 20 & 20 & 21 & 22 & 23 & 22 \\
\hline Ferro Total(mg Fe /l) & & & & 3.25 & 2.32 & 0.9 & 1.5 & 2.57 & 1.01 & 3.0 & 2.9 & 3.4 \\
\hline Manganês (mg Mn /l) & & & & & & & 0.08 & 0.05 & 0.05 & & 0.06 & 0.08 \\
\hline$\overline{\mathrm{DBO}}\left(\mathrm{mg} / \mathrm{L} \mathrm{O}_{2}\right)$ & 1.23 & 1.63 & 1.23 & 1.48 & 0.94 & 0.84 & 0.76 & 2.08 & 2.3 & 1.4 & 2.2 & 2.2 \\
\hline $\begin{array}{l}\mathrm{N}^{\circ} \text { Coliformes } \\
\text { Fecais }\left(\mathrm{N}^{\circ} 100 \mathrm{ml}\right)\end{array}$ & 7000 & 2600 & & 4000 & 4700 & 5900 & 5000 & 950 & 10500 & 57400 & 1400 & 1550 \\
\hline $\operatorname{Acidez}\left(\mathrm{mg} / \mathrm{l} \mathrm{CaCO}{ }_{3}\right)$ & 8.0 & 4.0 & 5.0 & 4.0 & 6.0 & 4.0 & 6.0 & 9.0 & 7.0 & 9.0 & 11.0 & 9.0 \\
\hline $\begin{array}{l}\text { Condutividade } \\
(\text { Ohm.cm) }\end{array}$ & 116 & 95 & 88 & 99 & 98 & 94 & 104 & 108 & 123 & 125 & 132 & 136 \\
\hline Cloretos $\left(\mathrm{mg} / \mathrm{l} \mathrm{Cl}^{-}\right)$ & 16 & 15 & 14 & 15 & 21 & 14 & 15 & 17 & 14 & 18 & 17 & 15 \\
\hline $\begin{array}{l}\text { Dureza total }(\mathrm{mg} / \mathrm{l} \\
\left.\mathrm{CaCO}_{3}\right)\end{array}$ & 42 & 34 & 41 & 37 & 23 & 25 & 27 & 28 & 38 & 49 & 53 & 49 \\
\hline Fenol (mg/L) & & & & & & & 0.002 & 0.005 & 0.002 & & 0.005 & 0.006 \\
\hline Surfactante (mg /L) & & & & & & & 0.01 & 0.01 & 0.01 & & 0.03 & 0 \\
\hline $\mathrm{OD}\left(\mathrm{mg} / \mathrm{L} \mathrm{O}_{2}\right)$ & 5.35 & 5.15 & 5.49 & 5.57 & 5.97 & 5.79 & 5.44 & 4.18 & 4.6 & 4.9 & 5.7 & 6.0 \\
\hline
\end{tabular}


Tabela 28: Características da água bruta da ETA J referente ao ano de 1996. Valores médios mensais.

\begin{tabular}{|l|l|l|l|r|r|r|r|r|r|r|r|r|}
\hline \multicolumn{1}{|c|}{ MÊS } & JAN & FEV & MAR & \multicolumn{1}{c|}{ ABR } & \multicolumn{1}{c|}{ MAI } & \multicolumn{1}{l|}{ JUN } & \multicolumn{1}{c|}{ JUL } & \multicolumn{1}{c|}{ AGO } & \multicolumn{1}{c|}{ SET } & OUT & \multicolumn{1}{c|}{ NOV } & \multicolumn{1}{c|}{ DEZ } \\
\hline Turbidez (uT) & & & & & & 26 & 20.5 & 26 & 49 & 54.6 & 70 & 32.5 \\
\hline Cor Aparente(uC) & & & & & & 167 & 139 & 166 & 264 & 360 & 365.5 & 293 \\
\hline pH & & & & & & 7.1 & 7.3 & 7.1 & 7.4 & 7.6 & 7.4 & 7.2 \\
\hline Ferro Total(mg Fe /l) & & & & 0.46 & 0.26 & 0.19 & 0.20 & 0.24 & 0.44 & 0.75 & 0.74 & 0.5 \\
\hline Manganês (mg Mn /l) & & & & 0.212 & 0.106 & 0.078 & 0.065 & 0.087 & 0.135 & 0.242 & 0.251 & 0.168 \\
\hline
\end{tabular}




\section{ANEXO C}

\section{QUESTIONÁRIO}

\section{I - Dados gerais da empresa:}

Nome:

Endereço:

Cidade:

Técnico responsável:

A empresa é autônoma, municipal, estadual ou privada?

Quando termina a concessão?

II - Dados Técnicos da água:

II-1 - Preencher as TABELAS abaixo com as características da água bruta dos últimos 5 anos: 
TABELA 1 : Características da água bruta do ano de 1992. Valores médios mensais.

\begin{tabular}{|c|c|c|c|c|c|c|c|c|c|c|c|c|}
\hline MẼS & JAN & FEV & MAR & ABR & MAI & JUN & JUL & AGO & SET & OUT & NOV & $\overline{D E Z}$ \\
\hline VAZĀO (1/s) & & & & & & & & & & & & \\
\hline TURBIDEZ (uT) & & & & & & & & & & & & \\
\hline COR APARENTE(uC) & & & & & & & & & & & & \\
\hline $\begin{array}{l}\text { OXIGËNIO } \\
\text { CONSUMIDO(mg/l) }\end{array}$ & & & & & & & & & & & & \\
\hline $\mathrm{pH}$ & & & & & & & & & & & & \\
\hline $\begin{array}{l}\text { ALCALINIDADE } \\
\text { TOTAL }\left(\mathrm{mg} / \mathrm{CaCO}_{3}\right)\end{array}$ & & & & & & & & & & & & \\
\hline $\begin{array}{l}\text { FERRO TOTAL } \\
(\mathrm{mg} \mathrm{Fe} / \mathrm{l})\end{array}$ & & & & & & & & & & & & \\
\hline $\begin{array}{l}\text { MANGANÊS } \\
(\mathrm{mg} \mathrm{Mn} / \mathrm{l})\end{array}$ & & & & & & & & & & & & \\
\hline ALGAS (UPA/ml) & & & & & & & & & & & & \\
\hline $\begin{array}{l}\mathrm{N}^{\circ}{ }^{\circ} \text { COLIFORMES } \\
\text { FECAIS }\left(\mathrm{N}^{\circ} 100 \mathrm{ml}\right)\end{array}$ & & & & & & & & & & & & \\
\hline TEMPERATURA $\left({ }^{\circ} \mathrm{C}\right)$ & & & & & & & & & & & & \\
\hline $\begin{array}{l}\text { CONDUTIVIDADE } \\
\text { (Ohm.cm) }\end{array}$ & & & & & & & & & & & & \\
\hline OUTROS (especificar) & & & & & & & & & & & & \\
\hline
\end{tabular}


TABELA 2 : Características da água bruta do ano de 1993. Valores médios mensais.

\begin{tabular}{|c|c|c|c|c|c|c|c|c|c|c|c|c|}
\hline MẼS & JAN & FEV & MAR & ABR & MAI & JUN & JUL & AGO & SET & OUT & NOV & $\overline{D E Z}$ \\
\hline VAZĀO (1/s) & & & & & & & & & & & & \\
\hline TURBIDEZ (uT) & & & & & & & & & & & & \\
\hline COR APARENTE(uC) & & & & & & & & & & & & \\
\hline $\begin{array}{l}\text { OXIGËNIO } \\
\text { CONSUMIDO(mg/l) }\end{array}$ & & & & & & & & & & & & \\
\hline $\mathrm{pH}$ & & & & & & & & & & & & \\
\hline $\begin{array}{l}\text { ALCALINIDADE } \\
\text { TOTAL }\left(\mathrm{mg} / \mathrm{CaCO}_{3}\right)\end{array}$ & & & & & & & & & & & & \\
\hline $\begin{array}{l}\text { FERRO TOTAL } \\
(\mathrm{mg} \mathrm{Fe} / \mathrm{l})\end{array}$ & & & & & & & & & & & & \\
\hline $\begin{array}{l}\text { MANGANÊS } \\
(\mathrm{mg} \mathrm{Mn} / \mathrm{l})\end{array}$ & & & & & & & & & & & & \\
\hline ALGAS (UPA/ml) & & & & & & & & & & & & \\
\hline $\begin{array}{l}\mathrm{N}^{\circ}{ }^{\circ} \text { COLIFORMES } \\
\text { FECAIS }\left(\mathrm{N}^{\circ} 100 \mathrm{ml}\right)\end{array}$ & & & & & & & & & & & & \\
\hline TEMPERATURA $\left({ }^{\circ} \mathrm{C}\right)$ & & & & & & & & & & & & \\
\hline $\begin{array}{l}\text { CONDUTIVIDADE } \\
\text { (Ohm.cm) }\end{array}$ & & & & & & & & & & & & \\
\hline OUTROS (especificar) & & & & & & & & & & & & \\
\hline
\end{tabular}


TABELA 3 : Características da água bruta do ano de 1994. Valores médios mensais.

\begin{tabular}{|c|c|c|c|c|c|c|c|c|c|c|c|c|}
\hline MẼS & JAN & FEV & MAR & ABR & MAI & JUN & JUL & AGO & SET & OUT & NOV & $\overline{D E Z}$ \\
\hline VAZĀO (1/s) & & & & & & & & & & & & \\
\hline TURBIDEZ (uT) & & & & & & & & & & & & \\
\hline COR APARENTE(uC) & & & & & & & & & & & & \\
\hline $\begin{array}{l}\text { OXIGËNIO } \\
\text { CONSUMIDO(mg/l) }\end{array}$ & & & & & & & & & & & & \\
\hline $\mathrm{pH}$ & & & & & & & & & & & & \\
\hline $\begin{array}{l}\text { ALCALINIDADE } \\
\text { TOTAL }\left(\mathrm{mg} / \mathrm{CaCO}_{3}\right)\end{array}$ & & & & & & & & & & & & \\
\hline $\begin{array}{l}\text { FERRO TOTAL } \\
(\mathrm{mg} \mathrm{Fe} / \mathrm{l})\end{array}$ & & & & & & & & & & & & \\
\hline $\begin{array}{l}\text { MANGANÊS } \\
(\mathrm{mg} \mathrm{Mn} / \mathrm{l})\end{array}$ & & & & & & & & & & & & \\
\hline ALGAS (UPA/ml) & & & & & & & & & & & & \\
\hline $\begin{array}{l}\mathrm{N}^{\circ}{ }^{\circ} \text { COLIFORMES } \\
\text { FECAIS }\left(\mathrm{N}^{\circ} 100 \mathrm{ml}\right)\end{array}$ & & & & & & & & & & & & \\
\hline TEMPERATURA $\left({ }^{\circ} \mathrm{C}\right)$ & & & & & & & & & & & & \\
\hline $\begin{array}{l}\text { CONDUTIVIDADE } \\
\text { (Ohm.cm) }\end{array}$ & & & & & & & & & & & & \\
\hline OUTROS (especificar) & & & & & & & & & & & & \\
\hline
\end{tabular}


TABELA 4 : Características da água bruta do ano de 1995. Valores médios mensais.

\begin{tabular}{|c|c|c|c|c|c|c|c|c|c|c|c|c|}
\hline MẼS & JAN & FEV & MAR & ABR & MAI & JUN & JUL & AGO & SET & OUT & NOV & $\overline{D E Z}$ \\
\hline VAZĀO (1/s) & & & & & & & & & & & & \\
\hline TURBIDEZ (uT) & & & & & & & & & & & & \\
\hline COR APARENTE(uC) & & & & & & & & & & & & \\
\hline $\begin{array}{l}\text { OXIGËNIO } \\
\text { CONSUMIDO(mg/l) }\end{array}$ & & & & & & & & & & & & \\
\hline $\mathrm{pH}$ & & & & & & & & & & & & \\
\hline $\begin{array}{l}\text { ALCALINIDADE } \\
\text { TOTAL }\left(\mathrm{mg} / \mathrm{CaCO}_{3}\right)\end{array}$ & & & & & & & & & & & & \\
\hline $\begin{array}{l}\text { FERRO TOTAL } \\
(\mathrm{mg} \mathrm{Fe} / \mathrm{l})\end{array}$ & & & & & & & & & & & & \\
\hline $\begin{array}{l}\text { MANGANÊS } \\
(\mathrm{mg} \mathrm{Mn} / \mathrm{l})\end{array}$ & & & & & & & & & & & & \\
\hline ALGAS (UPA/ml) & & & & & & & & & & & & \\
\hline $\begin{array}{l}\mathrm{N}^{\circ}{ }^{\circ} \text { COLIFORMES } \\
\text { FECAIS }\left(\mathrm{N}^{\circ} 100 \mathrm{ml}\right)\end{array}$ & & & & & & & & & & & & \\
\hline TEMPERATURA $\left({ }^{\circ} \mathrm{C}\right)$ & & & & & & & & & & & & \\
\hline $\begin{array}{l}\text { CONDUTIVIDADE } \\
\text { (Ohm.cm) }\end{array}$ & & & & & & & & & & & & \\
\hline OUTROS (especificar) & & & & & & & & & & & & \\
\hline
\end{tabular}


TABELA 5 : Características da água bruta do ano de 1996. Valores médios mensais.

\begin{tabular}{|c|c|c|c|c|c|c|c|c|c|c|c|c|}
\hline MẼS & JAN & FEV & MAR & ABR & MAI & JUN & JUL & AGO & SET & OUT & NOV & $\overline{D E Z}$ \\
\hline VAZĀO (1/s) & & & & & & & & & & & & \\
\hline TURBIDEZ (uT) & & & & & & & & & & & & \\
\hline COR APARENTE(uC) & & & & & & & & & & & & \\
\hline $\begin{array}{l}\text { OXIGËNIO } \\
\text { CONSUMIDO(mg/l) }\end{array}$ & & & & & & & & & & & & \\
\hline $\mathrm{pH}$ & & & & & & & & & & & & \\
\hline $\begin{array}{l}\text { ALCALINIDADE } \\
\text { TOTAL }\left(\mathrm{mg} / \mathrm{CaCO}_{3}\right)\end{array}$ & & & & & & & & & & & & \\
\hline $\begin{array}{l}\text { FERRO TOTAL } \\
(\mathrm{mg} \mathrm{Fe} / \mathrm{l})\end{array}$ & & & & & & & & & & & & \\
\hline $\begin{array}{l}\text { MANGANÊS } \\
(\mathrm{mg} \mathrm{Mn} / \mathrm{l})\end{array}$ & & & & & & & & & & & & \\
\hline ALGAS (UPA/ml) & & & & & & & & & & & & \\
\hline $\begin{array}{l}\mathrm{N}^{\circ}{ }^{\circ} \text { COLIFORMES } \\
\text { FECAIS }\left(\mathrm{N}^{\circ} 100 \mathrm{ml}\right)\end{array}$ & & & & & & & & & & & & \\
\hline TEMPERATURA $\left({ }^{\circ} \mathrm{C}\right)$ & & & & & & & & & & & & \\
\hline $\begin{array}{l}\text { CONDUTIVIDADE } \\
\text { (Ohm.cm) }\end{array}$ & & & & & & & & & & & & \\
\hline OUTROS (especificar) & & & & & & & & & & & & \\
\hline
\end{tabular}




\section{II-2 - Responder as perguntas abaixo sobre as características dos produtos químicos empregados:}

Qual o produto químico empregado na coagulação?

Qual o produto químico utilizado para correção do pH da água bruta e da água final?

Qual o produto químico empregado para desinfeção?

São utilizados produtos auxiliares? Quais?

Existe um controle de qualidade do produto químico utilizado no tratamento da água? Como é feito este controle no recebimento e no uso do produto?

Como é feito o transporte destes produtos do fabricante à ETA?

Qual o tipo de material no qual são embalados os produtos químicos pelo fabricante?

Como são armazenados os produtos químicos? E qual o tempo de armazenamento destes?

Como é feita a solicitação de produtos químicos? Anexar cópia da especificação do produto feita ao fabricante.

Existe uma previsão de uso dos produtos químicos (a ETA tem o produto em estoque, faz o pedido com a entrega marcada para uma data em que o estoque estaria pequeno)? 
II-3 - Preencher a Tabela sobre produtos químicos:

\begin{tabular}{|c|c|c|c|c|c|c|}
\hline produto químico & $\begin{array}{l}\text { fórmula } \\
\text { química }\end{array}$ & $\begin{array}{c}\text { pureza } \\
(\%)\end{array}$ & $\begin{array}{l}\text { dosagem } \\
\text { média anual } \\
(\mathrm{mg} / \mathrm{l})\end{array}$ & $\begin{array}{c}\text { equipamento } \\
\text { utilizado para a } \\
\text { dosagem }\end{array}$ & local de aplicação & fornecedor/cidade \\
\hline $\begin{array}{l}\text { sulfato de } \\
\text { alumínio }\end{array}$ & & & & & & \\
\hline cloreto férrico & & & & & & \\
\hline cal & & & & & & \\
\hline cloro & & & & & & \\
\hline ácido fluossilícico & & & & & & \\
\hline polímero natural & & & & & & \\
\hline polímero sintético & & & & & & \\
\hline $\begin{array}{l}\text { carvão ativado em } \\
\text { pó }\end{array}$ & & & & & & \\
\hline $\begin{array}{l}\text { outros } \\
\text { (especificar) }\end{array}$ & & & & & & \\
\hline
\end{tabular}




\section{II-4 Características da água bruta dos últimos cinco anos:}

TABELA 6 : Características da água tratada do ano de 1992. Valores médios mensais.

\begin{tabular}{|c|c|c|c|c|c|c|c|c|c|c|c|c|}
\hline \multirow{2}{*}{\multicolumn{13}{|c|}{$\frac{\text { MÊS }}{\text { VAZÃO(1/s) }}$}} \\
\hline & & & & & & & & & & & & \\
\hline \multicolumn{13}{|l|}{ TURBIDEZ (uT) } \\
\hline \multicolumn{13}{|l|}{ COR APARENTE(uC) } \\
\hline \multicolumn{13}{|l|}{$\mathrm{pH}$} \\
\hline \multirow{2}{*}{\multicolumn{13}{|c|}{$\begin{array}{l}\text { ALCALINIDADE TOTAL } \\
\left(\mathrm{mg} / \mathrm{l} \mathrm{CaCO}_{3}\right)\end{array}$}} \\
\hline & & & & & & & & & & & & \\
\hline \multicolumn{13}{|l|}{ MANGANÊS (mg Mn /l) } \\
\hline \multirow{2}{*}{\multicolumn{13}{|c|}{$\begin{array}{l}\text { N. }{ }^{\circ} \text { COLIFORMES TOTAIS } \\
\left(\mathrm{N}^{\circ} 100 \mathrm{ml}\right) \\
\mathrm{N} .{ }^{\circ} \text { COLIFORMES FECAIS }\end{array}$}} \\
\hline & & & & & & & & & & & & \\
\hline \multicolumn{13}{|c|}{ TEMPERATURA $\left({ }^{\circ} \mathrm{C}\right)$} \\
\hline \multicolumn{13}{|c|}{ CONDUTIVIDADE (Ohm.cm) } \\
\hline \multirow{2}{*}{\multicolumn{13}{|c|}{$\begin{array}{l}\text { OXIGÊNIO CONSUMIDO } \\
(\mathrm{mg} / \mathrm{l})\end{array}$}} \\
\hline & & & & & & & & & & & & \\
\hline \multicolumn{13}{|l|}{$\mathrm{CO}_{2}$ livre $(\mathrm{mg} / \mathrm{l})$} \\
\hline \multicolumn{13}{|c|}{ CLORO RESIDUAL (mg/l) } \\
\hline \multicolumn{13}{|l|}{ CLORETOS (mg/l) } \\
\hline \multicolumn{13}{|l|}{ SULFATOS (mg/l) } \\
\hline \multicolumn{13}{|l|}{ ALUMÍNIO (mg/l) } \\
\hline OUTROS (especificar) & & & & & & & & & & & & \\
\hline
\end{tabular}


TABELA 7 : Características da água tratada do ano de 1993. Valores médios mensais.

\begin{tabular}{|c|c|c|c|c|c|c|c|c|c|c|c|c|}
\hline MÊS & JAN & FEV & $\overline{\text { MAR }}$ & ABR & MAI & JUN & JUL & $\mathrm{AGO}$ & SET & $\overline{\text { OUT }}$ & NOV & DEZ \\
\hline$\overline{\mathrm{VAZĀO}(1 / \mathrm{s})}$ & & & & & & & & & & & & \\
\hline TURBIDEZ (uT) & & & & & & & & & & & & \\
\hline COR APARENTE(uC) & & & & & & & & & & & & \\
\hline$\overline{\mathrm{pH}}$ & & & & & & & & & & & & \\
\hline $\begin{array}{l}\text { ALCALINIDADE TOT } \\
\left(\mathrm{mg} / \mathrm{l} \mathrm{CaCO}_{3}\right)\end{array}$ & & & & & & & & & & & & \\
\hline FERRO TOTAL (mg Fe & & & & & & & & & & & & \\
\hline MANGANÊS (mg Mn & & & & & & & & & & & & \\
\hline $\begin{array}{l}\text { N. }{ }^{\circ} \text { COLIFORMES TO } \\
\left(\mathrm{N}^{\circ} 100 \mathrm{ml}\right)\end{array}$ & & & & & & & & & & & & \\
\hline $\begin{array}{l}\text { N. } .^{\circ} \text { COLIFORMES FEC } \\
\left(\mathrm{N}^{\circ} 100 \mathrm{ml}\right)\end{array}$ & & & & & & & & & & & & \\
\hline TEMPERATURA $\left({ }^{\circ} \mathrm{C}\right)$ & & & & & & & & & & & & \\
\hline CONDUTIVIDADE (O) & & & & & & & & & & & & \\
\hline $\begin{array}{l}\text { OXIGÊNIO CONSUMI } \\
(\mathrm{mg} / \mathrm{l})\end{array}$ & & & & & & & & & & & & \\
\hline FLÚOR (mg/l) & & & & & & & & & & & & \\
\hline$\overline{\mathrm{CO}_{2}}$ livre $(\mathrm{mg} / \mathrm{l})$ & & & & & & & & & & & & \\
\hline CLORO RESIDUAL (m & & & & & & & & & & & & \\
\hline CLORETOS (mg/l) & & & & & & & & & & & & \\
\hline SULFATOS (mg/l) & & & & & & & & & & & & \\
\hline ALUMÍNIO (mg/l) & & & & & & & & & & & & \\
\hline OUTROS (especificar) & & & & & & & & & & & & \\
\hline
\end{tabular}


TABELA 8 : Características da água tratada do ano de 1994. Valores médios mensais.

\begin{tabular}{|c|c|c|c|c|c|c|c|c|c|c|c|c|}
\hline MÊS & JAN & FEV & $\overline{\text { MAR }}$ & ABR & MAI & JUN & JUL & $\mathrm{AGO}$ & SET & $\overline{\text { OUT }}$ & NOV & DEZ \\
\hline$\overline{\mathrm{VAZĀO}(1 / \mathrm{s})}$ & & & & & & & & & & & & \\
\hline TURBIDEZ (uT) & & & & & & & & & & & & \\
\hline COR APARENTE(uC) & & & & & & & & & & & & \\
\hline$\overline{\mathrm{pH}}$ & & & & & & & & & & & & \\
\hline $\begin{array}{l}\text { ALCALINIDADE TOT } \\
\left(\mathrm{mg} / \mathrm{l} \mathrm{CaCO}_{3}\right)\end{array}$ & & & & & & & & & & & & \\
\hline FERRO TOTAL (mg Fe & & & & & & & & & & & & \\
\hline MANGANÊS (mg Mn & & & & & & & & & & & & \\
\hline $\begin{array}{l}\text { N. }{ }^{\circ} \text { COLIFORMES TO } \\
\left(\mathrm{N}^{\circ} 100 \mathrm{ml}\right)\end{array}$ & & & & & & & & & & & & \\
\hline $\begin{array}{l}\text { N. } .^{\circ} \text { COLIFORMES FEC } \\
\left(\mathrm{N}^{\circ} 100 \mathrm{ml}\right)\end{array}$ & & & & & & & & & & & & \\
\hline TEMPERATURA $\left({ }^{\circ} \mathrm{C}\right)$ & & & & & & & & & & & & \\
\hline CONDUTIVIDADE (O) & & & & & & & & & & & & \\
\hline $\begin{array}{l}\text { OXIGÊNIO CONSUMI } \\
(\mathrm{mg} / \mathrm{l})\end{array}$ & & & & & & & & & & & & \\
\hline FLÚOR (mg/l) & & & & & & & & & & & & \\
\hline$\overline{\mathrm{CO}_{2}}$ livre $(\mathrm{mg} / \mathrm{l})$ & & & & & & & & & & & & \\
\hline CLORO RESIDUAL (m & & & & & & & & & & & & \\
\hline CLORETOS (mg/l) & & & & & & & & & & & & \\
\hline SULFATOS (mg/l) & & & & & & & & & & & & \\
\hline ALUMÍNIO (mg/l) & & & & & & & & & & & & \\
\hline OUTROS (especificar) & & & & & & & & & & & & \\
\hline
\end{tabular}


TABELA 9 : Características da água tratada do ano de 1995. Valores médios mensais.

\begin{tabular}{|c|c|c|c|c|c|c|c|c|c|c|c|c|}
\hline MÊS & JAN & FEV & $\overline{\text { MAR }}$ & ABR & MAI & JUN & JUL & $\mathrm{AGO}$ & SET & $\overline{\text { OUT }}$ & NOV & DEZ \\
\hline$\overline{\mathrm{VAZĀO}(1 / \mathrm{s})}$ & & & & & & & & & & & & \\
\hline TURBIDEZ (uT) & & & & & & & & & & & & \\
\hline COR APARENTE(uC) & & & & & & & & & & & & \\
\hline$\overline{\mathrm{pH}}$ & & & & & & & & & & & & \\
\hline $\begin{array}{l}\text { ALCALINIDADE TOT } \\
\left(\mathrm{mg} / \mathrm{l} \mathrm{CaCO}_{3}\right)\end{array}$ & & & & & & & & & & & & \\
\hline FERRO TOTAL (mg Fe & & & & & & & & & & & & \\
\hline MANGANÊS (mg Mn & & & & & & & & & & & & \\
\hline $\begin{array}{l}\text { N. }{ }^{\circ} \text { COLIFORMES TO } \\
\left(\mathrm{N}^{\circ} 100 \mathrm{ml}\right)\end{array}$ & & & & & & & & & & & & \\
\hline $\begin{array}{l}\text { N. }{ }^{\circ} \text { COLIFORMES FEC } \\
\left(\mathrm{N}^{\circ} 100 \mathrm{ml}\right)\end{array}$ & & & & & & & & & & & & \\
\hline TEMPERATURA $\left({ }^{\circ} \mathrm{C}\right)$ & & & & & & & & & & & & \\
\hline CONDUTIVIDADE (O) & & & & & & & & & & & & \\
\hline $\begin{array}{l}\text { OXIGÊNIO CONSUMI } \\
(\mathrm{mg} / \mathrm{l})\end{array}$ & & & & & & & & & & & & \\
\hline FLÚOR (mg/l) & & & & & & & & & & & & \\
\hline$\overline{\mathrm{CO}_{2}}$ livre $(\mathrm{mg} / \mathrm{l})$ & & & & & & & & & & & & \\
\hline CLORO RESIDUAL (m & & & & & & & & & & & & \\
\hline CLORETOS (mg/l) & & & & & & & & & & & & \\
\hline SULFATOS (mg/l) & & & & & & & & & & & & \\
\hline ALUMÍNIO (mg/l) & & & & & & & & & & & & \\
\hline OUTROS (especificar) & & & & & & & & & & & & \\
\hline
\end{tabular}


TABELA 10 : Características da água tratada do ano de 1996. Valores médios mensais.

\begin{tabular}{|c|c|c|c|c|c|c|c|c|c|c|c|c|}
\hline MÊS & JAN & FEV & $\overline{\text { MAR }}$ & ABR & MAI & JUN & JUL & $\mathrm{AGO}$ & SET & $\overline{\text { OUT }}$ & NOV & DEZ \\
\hline$\overline{\mathrm{VAZĀO}(1 / \mathrm{s})}$ & & & & & & & & & & & & \\
\hline TURBIDEZ (uT) & & & & & & & & & & & & \\
\hline COR APARENTE(uC) & & & & & & & & & & & & \\
\hline $\mathrm{pH}$ & & & & & & & & & & & & \\
\hline $\begin{array}{l}\text { ALCALINIDADE TOT } \\
\left(\mathrm{mg} / \mathrm{l} \mathrm{CaCO}_{3}\right)\end{array}$ & & & & & & & & & & & & \\
\hline FERRO TOTAL (mg Fe & & & & & & & & & & & & \\
\hline MANGANÊS (mg Mn & & & & & & & & & & & & \\
\hline $\begin{array}{l}\text { N. }{ }^{\circ} \text { COLIFORMES TO } \\
\left(\mathrm{N}^{\circ} 100 \mathrm{ml}\right)\end{array}$ & & & & & & & & & & & & \\
\hline $\begin{array}{l}\text { N. }{ }^{\circ} \text { COLIFORMES FEC } \\
\left(\mathrm{N}^{\circ} 100 \mathrm{ml}\right)\end{array}$ & & & & & & & & & & & & \\
\hline TEMPERATURA $\left({ }^{\circ} \mathrm{C}\right)$ & & & & & & & & & & & & \\
\hline CONDUTIVIDADE (O) & & & & & & & & & & & & \\
\hline $\begin{array}{l}\text { OXIGÊNIO CONSUMI } \\
(\mathrm{mg} / \mathrm{l})\end{array}$ & & & & & & & & & & & & \\
\hline FLÚOR (mg/l) & & & & & & & & & & & & \\
\hline$\overline{\mathrm{CO}_{2}}$ livre $(\mathrm{mg} / \mathrm{l})$ & & & & & & & & & & & & \\
\hline CLORO RESIDUAL (m & & & & & & & & & & & & \\
\hline CLORETOS (mg/l) & & & & & & & & & & & & \\
\hline SULFATOS (mg/l) & & & & & & & & & & & & \\
\hline ALUMÍNIO (mg/l) & & & & & & & & & & & & \\
\hline OUTROS (especificar) & & & & & & & & & & & & \\
\hline
\end{tabular}




\section{II-5 - Características da qualidade da água tratada nas pontas de rede:}

TABELA 11 : Características da água tratada nas pontas de rede do ano de 1992. Valores médios mensais.

\begin{tabular}{|c|c|c|c|c|c|c|c|c|c|c|c|c|}
\hline \multirow{2}{*}{\multicolumn{13}{|c|}{$\frac{\text { MÊS }}{\text { TURBIDEZ (uT) }}$}} \\
\hline & & & & & & & & & & & & \\
\hline \multicolumn{13}{|l|}{ COR APARENTE(uC) } \\
\hline \multicolumn{13}{|l|}{$\mathrm{pH}$} \\
\hline \multicolumn{13}{|l|}{$\begin{array}{l}\text { ALCALINIDADE TOTAL } \\
\left(\mathrm{mg} / \mathrm{CaCO}_{3}\right)\end{array}$} \\
\hline \multicolumn{13}{|l|}{ FERRO TOTAL $(\mathrm{mg} \mathrm{Fe} / \mathrm{l})$} \\
\hline \multicolumn{13}{|l|}{ MANGANÊS $\quad(\mathrm{mg} \mathrm{Mn} / \mathrm{l})$} \\
\hline \multicolumn{13}{|l|}{ N. ${ }^{\circ}$ COLIFORMES } \\
\hline \multicolumn{12}{|l|}{ N. ${ }^{\circ}$ COLIFORMES } & FECAIS ( $\left.\mathrm{N}^{\circ} 100 \mathrm{ml}\right)$ \\
\hline \multicolumn{13}{|l|}{ TEMPERATURA $\left({ }^{\circ} \mathrm{C}\right)$} \\
\hline \multicolumn{13}{|l|}{ FLỨR (mg/l) } \\
\hline \multicolumn{13}{|l|}{$\mathrm{CO}_{2}$ residual $(\mathrm{mg} / \mathrm{l})$} \\
\hline \multicolumn{13}{|l|}{ CLORO RESIDUAL (mg/l) } \\
\hline \multicolumn{13}{|l|}{$\begin{array}{l}\text { ALUMÍNIO RESIDUAL } \\
(\mathrm{mg} / \mathrm{l})\end{array}$} \\
\hline OUTROS (especificar) & & & & & & & & & & & & \\
\hline
\end{tabular}


TABELA 12 : Características da água tratada nas pontas de rede do ano de 1993. Valores médios mensais.

\begin{tabular}{|c|c|c|c|c|c|c|c|c|c|c|c|c|}
\hline MÊS & JAN & $\overline{\text { FEV }}$ & $\overline{\text { MAR }}$ & $\overline{\mathrm{ABR}}$ & MAI & JUN & 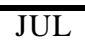 & $\mathrm{AGO}$ & SET & OUT & $\overline{\mathrm{NOV}}$ & $\overline{\mathrm{DEZ}}$ \\
\hline TURBIDEZ (uT) & & & & & & & & & & & & \\
\hline COR APARENTE(uC) & & & & & & & & & & & & \\
\hline $\mathrm{pH}$ & & & & & & & & & & & & \\
\hline $\begin{array}{l}\text { ALCALINIDADE TOTAL } \\
\left(\mathrm{mg} / \mathrm{CaCO}_{3}\right)\end{array}$ & & & & & & & & & & & & \\
\hline FERRO TOTAL (mg Fe /l & & & & & & & & & & & & \\
\hline MANGANÊS $\quad(\mathrm{mg} \mathrm{Mn} / \mathrm{l}$ & & & & & & & & & & & & \\
\hline $\begin{array}{l}\text { N. }{ }^{\circ} \text { COLIFORMES } \\
\text { TOTAIS }\left(\mathrm{N}^{\circ} 100 \mathrm{ml}\right)\end{array}$ & & & & & & & & & & & & \\
\hline $\begin{array}{l}\mathrm{N}^{\circ}{ }^{\circ} \text { COLIFORMES } \\
\text { FECAIS }\left(\mathrm{N}^{\circ} 100 \mathrm{ml}\right)\end{array}$ & & & & & & & & & & & & \\
\hline TEMPERATURA $\left({ }^{\circ} \mathrm{C}\right)$ & & & & & & & & & & & & \\
\hline FLÚOR (mg/l) & & & & & & & & & & & & \\
\hline $\mathrm{CO}_{2}$ residual $(\mathrm{mg} / \mathrm{l})$ & & & & & & & & & & & & \\
\hline CLORO RESIDUAL (mg/l & & & & & & & & & & & & \\
\hline $\begin{array}{l}\text { ALUMÍNIO RESIDUAL } \\
(\mathrm{mg} / \mathrm{l})\end{array}$ & & & & & & & & & & & & \\
\hline OUTROS (especificar) & & & & & & & & & & & & \\
\hline
\end{tabular}


TABELA 13 : Características da água tratada nas pontas de rede do ano de 1994. Valores médios mensais.

\begin{tabular}{|c|c|c|c|c|c|c|c|c|c|c|c|c|}
\hline MÊS & JAN & $\overline{\text { FEV }}$ & $\overline{\text { MAR }}$ & $\overline{\mathrm{ABR}}$ & MAI & JUN & 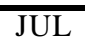 & $\mathrm{AGO}$ & SET & OUT & $\overline{\mathrm{NOV}}$ & $\overline{\mathrm{DEZ}}$ \\
\hline TURBIDEZ (uT) & & & & & & & & & & & & \\
\hline COR APARENTE(uC) & & & & & & & & & & & & \\
\hline $\mathrm{pH}$ & & & & & & & & & & & & \\
\hline $\begin{array}{l}\text { ALCALINIDADE TOTAL } \\
\left(\mathrm{mg} / \mathrm{CaCO}_{3}\right)\end{array}$ & & & & & & & & & & & & \\
\hline FERRO TOTAL (mg Fe /l & & & & & & & & & & & & \\
\hline MANGANÊS $\quad(\mathrm{mg} \mathrm{Mn} / \mathrm{l}$ & & & & & & & & & & & & \\
\hline $\begin{array}{l}\text { N. }{ }^{\circ} \text { COLIFORMES } \\
\text { TOTAIS }\left(\mathrm{N}^{\circ} 100 \mathrm{ml}\right)\end{array}$ & & & & & & & & & & & & \\
\hline $\begin{array}{l}\mathrm{N}^{\circ}{ }^{\circ} \text { COLIFORMES } \\
\text { FECAIS }\left(\mathrm{N}^{\circ} 100 \mathrm{ml}\right)\end{array}$ & & & & & & & & & & & & \\
\hline TEMPERATURA $\left({ }^{\circ} \mathrm{C}\right)$ & & & & & & & & & & & & \\
\hline FLÚOR (mg/l) & & & & & & & & & & & & \\
\hline $\mathrm{CO}_{2}$ residual $(\mathrm{mg} / \mathrm{l})$ & & & & & & & & & & & & \\
\hline CLORO RESIDUAL (mg/l & & & & & & & & & & & & \\
\hline $\begin{array}{l}\text { ALUMÍNIO RESIDUAL } \\
(\mathrm{mg} / \mathrm{l})\end{array}$ & & & & & & & & & & & & \\
\hline OUTROS (especific ar) & & & & & & & & & & & & \\
\hline
\end{tabular}


TABELA 14 : Características da água tratada nas pontas de rede do ano de 1995. Valores médios mensais.

\begin{tabular}{|c|c|c|c|c|c|c|c|c|c|c|c|c|}
\hline MÊS & JAN & $\overline{\text { FEV }}$ & $\overline{\text { MAR }}$ & $\overline{\mathrm{ABR}}$ & MAI & JUN & 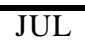 & $\mathrm{AGO}$ & SET & OUT & $\overline{\mathrm{NOV}}$ & $\overline{\mathrm{DEZ}}$ \\
\hline TURBIDEZ (uT) & & & & & & & & & & & & \\
\hline COR APARENTE(uC) & & & & & & & & & & & & \\
\hline $\mathrm{pH}$ & & & & & & & & & & & & \\
\hline $\begin{array}{l}\text { ALCALINIDADE TOTAL } \\
\left(\mathrm{mg} / \mathrm{CaCO}_{3}\right)\end{array}$ & & & & & & & & & & & & \\
\hline FERRO TOTAL (mg Fe /l & & & & & & & & & & & & \\
\hline MANGANÊS $\quad(\mathrm{mg} \mathrm{Mn} / \mathrm{l}$ & & & & & & & & & & & & \\
\hline $\begin{array}{l}\text { N. }{ }^{\circ} \text { COLIFORMES } \\
\text { TOTAIS (N'100 ml) }\end{array}$ & & & & & & & & & & & & \\
\hline $\begin{array}{l}\mathrm{N}^{\circ}{ }^{\circ} \text { COLIFORMES } \\
\text { FECAIS }\left(\mathrm{N}^{\circ} 100 \mathrm{ml}\right)\end{array}$ & & & & & & & & & & & & \\
\hline TEMPERATURA $\left({ }^{\circ} \mathrm{C}\right)$ & & & & & & & & & & & & \\
\hline FLÚOR (mg/l) & & & & & & & & & & & & \\
\hline $\mathrm{CO}_{2}$ residual $(\mathrm{mg} / \mathrm{l})$ & & & & & & & & & & & & \\
\hline CLORO RESIDUAL (mg/l & & & & & & & & & & & & \\
\hline $\begin{array}{l}\text { ALUMÍNIO RESIDUAL } \\
(\mathrm{mg} / \mathrm{l})\end{array}$ & & & & & & & & & & & & \\
\hline OUTROS (especificar) & & & & & & & & & & & & \\
\hline
\end{tabular}


TABELA 15 : Características da água tratada nas pontas de rede do ano de 1996. Valores médios mensais.

\begin{tabular}{|c|c|c|c|c|c|c|c|c|c|c|c|c|}
\hline MÊS & JAN & $\overline{\text { FEV }}$ & $\overline{\text { MAR }}$ & $\overline{\mathrm{ABR}}$ & MAI & JUN & 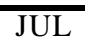 & $\mathrm{AGO}$ & SET & OUT & $\overline{\mathrm{NOV}}$ & $\overline{\mathrm{DEZ}}$ \\
\hline TURBIDEZ (uT) & & & & & & & & & & & & \\
\hline COR APARENTE(uC) & & & & & & & & & & & & \\
\hline $\mathrm{pH}$ & & & & & & & & & & & & \\
\hline $\begin{array}{l}\text { ALCALINIDADE TOTAL } \\
\left(\mathrm{mg} / \mathrm{CaCO}_{3}\right)\end{array}$ & & & & & & & & & & & & \\
\hline FERRO TOTAL (mg Fe /l & & & & & & & & & & & & \\
\hline MANGANÊS (mg Mn /l) & & & & & & & & & & & & \\
\hline $\begin{array}{l}\text { N. }{ }^{\circ} \text { COLIFORMES } \\
\text { TOTAIS (Nº0 ml) }\end{array}$ & & & & & & & & & & & & \\
\hline $\begin{array}{l}{ }^{\circ}{ }^{\circ} \text { COLIFORMES } \\
\text { FECAIS }\left(\mathrm{N}^{\circ} 100 \mathrm{ml}\right)\end{array}$ & & & & & & & & & & & & \\
\hline TEMPERATURA $\left({ }^{\circ} \mathrm{C}\right)$ & & & & & & & & & & & & \\
\hline FLÚOR (mg/l) & & & & & & & & & & & & \\
\hline $\mathrm{CO}_{2}$ residual $(\mathrm{mg} / \mathrm{l})$ & & & & & & & & & & & & \\
\hline CLORO RESIDUAL (mg/l & & & & & & & & & & & & \\
\hline $\begin{array}{l}\text { ALUMÍNIO RESIDUAL } \\
(\mathrm{mg} / \mathrm{l})\end{array}$ & & & & & & & & & & & & \\
\hline OUTROS (especificar) & & & & & & & & & & & & \\
\hline
\end{tabular}


III - Dados operacionais da estação de tratamento de água:

Qual a tecnologia de tratamento empregada?

( ) tratamento completo (convencional)

( ) filtração direta

Quantas bombas existem na estação de tratamento de água? Especificar a função de cada uma.

Qual a potência das bombas utilizadas?

Qual o tempo de funcionamento diário (horas/dia)?

Qual o consumo médio anual de energia elétrica da ETA?

III-1 - TABELA 16 Características da coagulação (mistura rápida):

\begin{tabular}{|c|c|c|c|}
\hline $\begin{array}{c}\text { tipo de mistura } \\
\text { rápida }\end{array}$ & $\begin{array}{c}\mathrm{pH} \\
\text { coagulação }\end{array}$ & $\begin{array}{c}\text { tempo de } \\
\text { mistura (s) }\end{array}$ & $\begin{array}{c}\text { gradiente médio de } \\
\text { velocidade }\left(\mathrm{s}^{-1}\right)\end{array}$ \\
\hline & & & \\
\hline
\end{tabular}

III-2 - TABELA 17 Características da floculação (mistura lenta):

\begin{tabular}{|c|c|c|c|c|}
\hline $\begin{array}{c}\text { tipo de mistura } \\
\text { lenta }\end{array}$ & $\begin{array}{c}\mathrm{pH} \\
\text { coagulação }\end{array}$ & $\begin{array}{c}\text { tempo total de } \\
\text { mistura (min) }\end{array}$ & $\begin{array}{c}\mathrm{n} .^{\circ} \text { de } \\
\text { câmaras }\end{array}$ & $\begin{array}{c}\text { gradiente médio de } \\
\text { velocidade em cada } \\
\text { câmara }\left(\mathrm{s}^{-1}\right)\end{array}$ \\
\hline & & & & \\
\hline
\end{tabular}

III-3 - TABELA 18 Dimensões das diversas unidades da estação de tratamento de água:

\begin{tabular}{|l|l|l|l|l|l|}
\hline unidades & $\begin{array}{l}\text { n. - de } \\
\text { unidades }\end{array}$ & $\begin{array}{c}\text { profundidade } \\
(\mathrm{m})\end{array}$ & largura $(\mathrm{m})$ & $\begin{array}{c}\text { comprimento } \\
(\mathrm{m})\end{array}$ & volume $\left(\mathrm{m}^{\mathrm{s}}\right)$ \\
\hline floculador & & & & & \\
\hline decantador & & & & & \\
\hline filtro & & & & & \\
\hline $\begin{array}{l}\text { reservatório (câmara) } \\
\text { de contato }\end{array}$ & & & & & \\
\hline
\end{tabular}


$\mathrm{Na}$ tabela 18, os floculadores, decantadores e filtros, todos apresentam as mesmas dimensões e mesma tecnologia?

III-4 - TABELA 19 Características do decantador utilizado na ETA:

\begin{tabular}{|c|c|c|c|c|c|}
\hline \multicolumn{2}{|c|}{ decantador } & $\begin{array}{c}\text { tempo } \\
\text { regular de } \\
\text { limpeza }\end{array}$ & $\begin{array}{c}\text { freqüência } \\
\text { de limpeza }\end{array}$ & $\begin{array}{l}\text { limpeza do } \\
\text { decantador } \\
\text { é: }\end{array}$ & $\begin{array}{c}\text { tipo de fundo } \\
\text { do decantador }\end{array}$ \\
\hline convencional & alta taxa & & & $\begin{array}{l}\text { ( )manual } \\
\text { ( )mecânica }\end{array}$ & $\begin{array}{l}\text { ( )plano } \\
\text { ( )inclinado }\end{array}$ \\
& $\begin{array}{l}\text { ( )placas planas } \\
\text { paralelas } \\
\text { ( ) duto de seção } \\
\text { quadrada }\end{array}$ & & $\begin{array}{l}\text { ( )tronco de } \\
\text { pirâmide }\end{array}$ \\
\hline
\end{tabular}

III-5 - TABELA 20 Características dos filtros da estação de tratamento de água:

\begin{tabular}{|c|c|c|c|c|c|c|}
\hline filtro & $\begin{array}{c}\text { meio } \\
\text { filtrante }\end{array}$ & $\begin{array}{c}\text { intervalo } \\
\text { entre } \\
\text { lavagens }\end{array}$ & $\begin{array}{c}\text { vazão } \\
\text { utilizada } \\
\text { na } \\
\text { lavagem } \\
(\mathrm{l} / \mathrm{s})\end{array}$ & $\begin{array}{c}\text { duração } \\
\text { da } \\
\text { lavagem }\end{array}$ & método de lavagem & $\begin{array}{c}\text { água de lavagem } \\
\text { proveniente }\end{array}$ \\
\hline & $\begin{array}{c}\text { ( ) areia } \\
\text { antracito } \\
\text { ( ) areia e } \\
\text { antracia, } \\
\text { e granada }\end{array}$ & & & & $\begin{array}{l}\text { ( ) somente água } \\
\text { ( ) ar seguido de água } \\
\text { ( ) ar e água } \\
\text { simultâneo } \\
\text { ( ) auxiliar superficial } \\
\text { com tubulação fixa } \\
\text { ( ) auxiliar com } \\
\text { torniquete hidráulico } \\
\text { ( ) auxiliar sub- } \\
\text { superficial com } \\
\text { tubulação fixa }\end{array}$ & $\left(\begin{array}{c}\text { ( ) filtros } \\
\text { remanescentes } \\
\left(\begin{array}{c}\text { elevado } \\
\text { reservatório }\end{array}\right. \\
(\quad \text { ) bombeamento } \\
\text { direto }\end{array}\right.$ \\
\hline
\end{tabular}

III-6 - Se a água de lavagem dos filtros for proveniente de reservatório elevado preencher a TABELA 21:

TABELA 21: Dados do reservatório elevado:

\begin{tabular}{|l|l|l|l|}
\hline reservatório & altura $(\mathrm{m})$ & volume $\left(\mathrm{m}^{3}\right)$ & desnível geométrico $(\mathrm{m})$ \\
\hline retangular & & & \\
\hline circular & & & \\
\hline
\end{tabular}




\section{IV - Laboratório:}

A empresa possui laboratório?

Quais os equipamentos existentes no laboratório?

Qual a freqüência que é feito manutenção nos equipamentos?

Quais são as análises de rotina?

Quem é o responsável pelo laboratório e qual sua formação?

\section{V - Recursos humanos:}

\begin{tabular}{|l|l|l|l|}
\hline $\begin{array}{c}\text { Turnos de } \\
\text { trabalho }\end{array}$ & $\begin{array}{c}\text { Número de } \\
\text { funcionários/turno }\end{array}$ & Formação & $\begin{array}{c}\text { Atividade } \\
\text { desenvolvida }\end{array}$ \\
\hline & & & \\
\hline & & & \\
\hline & & & \\
\hline & & & \\
\hline & & & \\
\hline & & & \\
\hline
\end{tabular}

Qual a qualificação dos operadores da ETA que trabalham nos finais de semana e feriados?

Existe algum tipo de treinamento dos funcionários? Qual?

Os funcionários possuem acesso a informações (livros, material didático, etc.)?

A ETA possui computadores? Qual sua utilização?

Existe algum serviço automatizado na ETA? Qual?

Já ocorreu na ETA algum acidente por manipulação inadequada de produtos químicos e equipamentos? Quando? Quantas vezes?

\section{VI - Equipamentos de segurança:}

Quais são os equipamentos de segurança usados na ETA? 


\section{REFERÊNCIAS BIBLIOGRÁFICAS}

AMARAL, S. P. (1997). Gestão e certificação ambiental ISSO 14000 no Brasil. Saneamento Ambiental, n. ${ }^{\circ}$ 47, p30-34.

ASSOCIAÇÃO BRASILEIRA DE NORMAS TÉCNICAS (1977). NBR 592 Elaboração de projetos de sistemas de tratamento de água para abastecimento público. Rio de Janeiro.

ASSOCIAÇÃO BRASILEIRA DE NORMAS TÉCNICAS (19). NBR 11.177 amostragem do sulfato de alumínio; NBR 11.176; 11.178; 11.179; 11.180; 11.181 e 11.182 - grau de pureza que para o sulfato de alumínio; NBR 7.546 - grau de pureza para o cloreto férrico; NBR 10.790 - grau de pureza para a cal virgem e hidratada; NBR 12.143 e 12.144 - grau de pureza para o cloro; NBR 7.977; 11.934 e 13.176 - grau de pureza para o polímero; NBR 10.790 e 12.805 especificações sobre o extintor de cal. Rio de Janeiro.

ASSOCIAÇÃO NACIONAL DOS SERVIÇOS MUNICIPAIS DE SANEMAENTO; FEDERAÇÃO NACIONAL DOS URBANITÁRIOS (1996). Concessões privadas: radiografia de um equívoco.

AZEVEDO, E. A ; ALENCAR, M. L. M. (1995). Concessões de serviços públicos. Engenharia. São Paulo, n. 508, p 58-59.

BRANCO, A M. (1995). Serviços de utilidade pública. Engenharia. São Paulo, n. $508, \mathrm{p}$ 49-57.

BROCKA, B.; BROCKA, M. S.(1994). Gerenciamento da qualidade. São Paulo. Makron Books.

BRASIL. Leis (1965). Lei N. 4771 de 15 de setembro de 1965. Institui o Novo Código Florestal, com as alterações introduzidas pela Lei n. ${ }^{\circ}$ 7.803, de 18.07.89.

BRASIL. Leis (1986). Resolução CONAMA N. ${ }^{\circ} 20$ de 18 de junho de 1986. Classificação das águas doces, salobras e salinas do território Nacional. 
BRASIL. Leis (1990). Portaria N. ${ }^{\circ}$ 36/GM de 19 de janeiro de 1990. Normas e padrão de potabilidade da água para todo o território Nacional.

BRASIL. Leis (1995). Lei N. ${ }^{\circ} 8987$ de 13 de fevereiro de 1995. Dispõe sobre o regime de concessão e permissão da prestação de serviços públicos previstos m art. 175 da Constituição Federal. Diário Oficial da União, Brasília, DF, 14 fev., Seção I, p. 1917-1922.

CAMPOS, L. C.(1992). Influência das características geométricas do agitador mecânico de paleta giratórias paralelas ao eixo vertical na potência introduzida na água. São Carlos. Dissertação (Mestrado) - Escola de Engenharia de São Carlos, Universidade de São Paulo.

CARTER, A (1995). As program management function evolves, benefits increase. Water/Engineering \& Management, v. 142 , n. 3, p 26-29, march.

COELHO, E. R. C.(1990). Estudo da taxa de aplicação superficial em uma instalação piloto de flotação por ar dissolvido aplicada ao tratamento de água para abastecimento. São Carlos. Dissertação (Mestrado) - Escola de Engenharia de São Carlos, Universidade de São Paulo.

CORDEIRO, J. S.(1993). O problema dos lodos gerados nos decantadores em estações de tratamento de água. São Carlos. Tese (Doutorado) - Escola de Engenharia de São Carlos, Universidade de São Paulo.

COSTA, E. R. H. (1992). Estudo do uso de polímeros naturais como auxiliares de floculação com base no diagrama de coagulação do sulfato de alumínio. São Carlos. Dissertação (Mestrado) - Escola de Engenharia de São Carlos, Universidade de São Paulo.

COSTA, E. R. H. (1997). Melhoria da qualidade da água tratada e aumento da capacidade de ETA através da escolha adequada de coagulantes e auxiliares em águas em águas com alcalinidade alta(estudo de caso). $19^{\circ}$ CONGRESSO BRASILEIRO DE ENGENHARIA SANITÁRIA E AMBIENTAL. Foz do Iguaçu, p 108-109.

COSTA, J. I. N.(1996). Sedimentação de partículas discreta em dutos utilizados na decantação de alta taxa considerando escoamento laminar nos trechos de transição e de perfil desenvolvido. São Carlos. Dissertação (Mestrado) - Escola de Engenharia de São Carlos, Universidade de São Paulo. 
CUNHA, F. H. R.(1989). Estudo do comportamento hidráulico e da eficiência na sedimentação de alta taxa. São Carlos. Dissertação (Mestrado) - Escola de Engenharia de São Carlos, Universidade de São Paulo.

CUNHA, N. P. Jr. (1992). Estudo comparativo de filtros rápidos de camada simples de areia e de camada dupla. São Carlos. Dissertação (Mestrado) - Escola de Engenharia de São Carlos, Universidade de São Paulo.

DIAS, R. (1995). As empresas e o padrão de qualidade ambiental. Economia \& Empresa. São Paulo, v. 2, n. 3, p 37-41, jul./set.

DIAS, R. (1996). Ausência de mata afeta a água em Franca. Folha de São Paulo, São Paulo, 22abr.

DI BERNARDO, L. (1993). Métodos e Técnicas de Tratamento de Água. Rio de Janeiro. ABES, v. 1 e 2.

DOMBROSKI, S.A.G. (1996). Influência das condições de floculação na eficiência da flotação por ar dissolvido de alta taxa aplicada ao tratamento de água de abastecimento. São Carlos. Dissertação (Mestrado) - Escola de Engenharia de São Carlos, Universidade de São Paulo.

FUKS, J. L. (1987). O gerente como fator de sucesso nas empresas de saneamento básico. $14^{\circ}$ CONGRESSO BRASILEIRO DE ENGENHARIA SANITÁRIA E AMBIENTAL. São Paulo.

GASTALDINI, M. C. C. (1990). Filtração rápida descendente com taxa constante em meios granulares não uniformes: modelação $e$ análise econômica $e$ operacional. São Carlos. Tese (Doutorado) - Escola de Engenharia de São Carlos, Universidade de São Paulo.

GOLDFINCH, R. (1998). Water industry financing - a global perspective. WQI. $\mathrm{Jan} / \mathrm{Feb}$.

HOEKSTRA, A.C.; Van der Zwan, J.T. (1996). Total quality management in a water company: a pioneering experience in the Netherlands. Water Supply, v. 14, n. 1 , p. 127-132.

INFORMATIVO MENSAL DO INSTITUTO DE ENGENHARIA (1997). n. ${ }^{\circ}$ 162, mar., p. 8 e 9 .

KNOCKE, W. R., HAMON, J. R., DULIN, B. E. (1987). Effects os coagulation on sludge thickening and dewatering. JAWWA., Denver, v. 79, n. 6, p. 89-98, June. 
KRIS, J.; MARTON, J.; CERMAK, O (1995). Control and management of the distribution and service system. Water Supply, v. 13, n. 3-4, p. 25-28.

LIBÂNIO, M., PÁDUA, V. L., BERNARDO, L. D. (1996). Avaliação do Modelo de Argaman \& Daufman na estimativa do desempenho de unidades de floculação aplicadas ao Tratamento das Águas de Abastecimento. Engenharia Sanitária e Ambiental. Rio de Janeiro, v. 2, n. 1, p. 11-18, abr.jun.

LUIZ, E. (1997). Mananciais estão comprometidos. Jornal O Estado de São Paulo. São Paulo. 13 de jan. Ambiente, p. A11.

MANUAL para operadores de ETA (1971). São Paulo. Faculdade de Saúde Pública - Universidade de São Paulo; Subin, B. N. H.; USAID - Brasil. Ed. CETESB.

MATSUMOTO, T. (1987). Comparação entre a filtração ascendente e descendente de água decantada utilizando areia como meio filtrante. São Carlos. Dissertação (Mestrado) - Escola de Engenharia de São Carlos, Universidade de São Paulo.

MENDES, C. G. N.(1989). Estudo da coagulação e floculação de águas sintéticas e naturais com turbidez e cor variáveis. São Carlos. Tese(Doutorado) - Escola de Engenharia de São Carlos, Universidade de São Paulo.

MIGHIGAN, M. (1998). Comitê vai regulamentar cobrança. Jornal O Estado de São Paulo. São Paulo. 14 jan.

MOLINA, F. R. O.(1996). Comparação do desempenho do carvão antracitoso e carvão betuminoso como materiais filtrantes em filtros de dupla camada. São Carlos. Dissertação (Mestrado) - Escola de Engenharia de São Carlos, Universidade de São Paulo.

MONTEIRO, J. G. A M.; POSSAMAI, O. (1995). Gerenciamento de processos empresariais: interface direta com o processo produtivo. INTERNACIONAL CONGRESS OF INDUSTRIAL ENGINEERING UFSCar, 1, São Carlos, 1992. Anais. São Carlos.

NEGREIROS, S. (1997). Águas de Limeira: a experiência da concessão. Saneamento Ambiental. N. ${ }^{\circ}$ 47, p 24-29.

PAIXÃO, G. C.(1996). Estudo da coagulação-floculação-sedimentação de água com turbidez ou cor elevada, utilizando polímero sintético como auxiliar de floculação. São Carlos. Dissertação (Mestrado) - Escola de Engenharia de São Carlos, Universidade de São Paulo. 
PEIXOTO, J. A. A. (1995). Influência de fatores subjetivos nos processos de gestão das empresas. INTERNACIONAL CONGRESS OF INDUSTRIAL ENGINEERING UFSCar, 1, São Carlos, 1995. Anais. São Carlos.

PENNA, J. A.(1984). Estudos sobre a influência da mistura rápida hidráulica na floculação de águas de abastecimento. São Carlos. Dissertação (Mestrado) Escola de Engenharia de São Carlos, Universidade de São Paulo.

PRETO, E. L; BÁGGIO, M.A. (1994). Planejamento operacional aplicado à operação \& manutenção de sistemas de água e esgoto. $16^{\circ}$ CONGRESSO BRASILEIRO DE ENGENHARIA SANITÁRIA E AMBIENTAL, v.2, tomo III.

PREZOTTI, J. C. S. (1990). Influência da taxa de filtração no desempenho de filtros rápidos de areia praticamente uniforme. São Carlos. Dissertação (Mestrado) Escola de Engenharia de São Carlos, Universidade de São Paulo.

REALI, Marco A. P. (1984). Aplicação da flotação por ar dissolvido ao tratamento de águas de abastecimento. São Carlos. Dissertação (Mestrado) - Escola de Engenharia de São Carlos, Universidade de São Paulo.

REALI, Marco A. P. (1991). Concepção e avaliação de um sistema compacto para tratamento de águas de abastecimento utilizando o processo de flotação por ar dissolvido e filtração com taxa declinante. São Carlos. Tese (Doutorado) - Escola de Engenharia de São Carlos, Universidade de São Paulo.

REIS, L. F. R. (1985). Projeto ótimo de filtros rápidos de areia de fluxo descendente. São Carlos. Dissertação (Mestrado) - Escola de Engenharia de São Carlos, Universidade de São Paulo.

ROMANO, P. A.(1996). Água e Desperdício. Jornal Estado de São Paulo, 13jun.

SALVADOR, N. B. (1990). Avaliação de impactos sobre qualidade dos recursos hídricos. São Carlos. Tese (Doutorado) - Escola de Engenharia de São Carlos, Universidade de São Paulo.

SANEAMENTO E MUNICÍPIOS (Dez 96/Jan 97). Qualidade da água. p. 16-17.

SANTOS, S. P. (1997). Estudo de uma unidade de flotação por ar dissolvido com escoamento vertical entre placas, aplicada à remoção de algas em águas de abastecimento. São Carlos. Dissertação (Mestrado) - Escola de Engenharia de São Carlos, Universidade de São Paulo. 
SÃO PAULO (Estado). Leis (1976). Lei N. ${ }^{o} 997$ de 31 de maio de 1976. Dispõe sobre o controle da poluição do meio ambiente. São Paulo, p.5-13.

SCALIZE, P. S. (1997). Caracterização e clarificação por sedimentação da água de lavagem dos filtros rápidos de estações de tratamento de água que utilizam sulfato de alumínio como coagulante primário. São Carlos. Dissertação (Mestrado) - Escola de Engenharia de São Carlos, Universidade de São Paulo.

SENGE, P. M. (1990). A quinta disciplina. São Paulo. Editora Best Seller.

SIMON, R. (1996). Service quality: an opportunity for water distribution companies. Water Supply, v. 14, n. 1, p 133-137;

SLACK, N.; CHAMBERS, S.; HARLAND, C.; HARRISON, A.; JOHNSTON, R. (1997). Administração da produção. São Paulo. Atlas;

SMITH, A.F.; GREEN, J.W.; MATTHEUS, P.J. (1995). Water supply management in the UK: lessons for the 21st century. Water Supply, v. 13, n. 3-4, p 183-187;

SOUZA, E. F. (1995). Custo, Produção e Gestão Estratégica. INTERNACIONAL CONGRESS OF INDUSTRIAL ENGINEERING UFSCar, 1, São Carlos, 1992. Anais. São Carlos.

SOUZA, R. S. (1990). Influência do posicionamento do vertedor de saída nos sistemas de filtração com taxa declinante e taxa constante com nível variável. São Carlos. Dissertação (Mestrado) - Escola de Engenharia de São Carlos, Universidade de São Paulo.

TANAKA, R. T.; FERRAUCHE, W.; SANTOS, J. L.Fo(1971). Serviços de Saneamento Básico devem funcionar em bases empresariais. VI CONGRESSO BRASILEIRO DE ENGENHARIA SANITÁRIA, São Paulo, v 1, jan.

TEIXEIRA, B. A. N. (1991). Proposição de um método para obtenção de parâmetros de projeto e operação de sistemas de filtração com taxa declinante. São Carlos. Dissertação (Mestrado) - Escola de Engenharia de São Carlos, Universidade de São Paulo.

WIECHETECK, G. K.(1996). Influência do método de lavagem nas características de carvões antracitoso e betuminoso utilizados em meio filtrante. São Carlos. Dissertação (Mestrado) - Escola de Engenharia de São Carlos, Universidade de São Paulo. 